$12 / 88.95 \mathrm{~g} / \mathrm{S}(1)$

\title{
Technical and Economic Assessment of Producing Hyd ogen by Reforming Syngas from the Battelle Indirectly Heated Biomass Gasifier
}

Margaret K. Mann

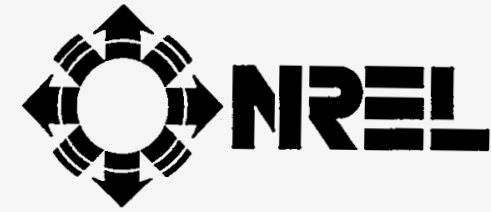

National Renewable Energy Laboratory 1617 Cole Boulevard Golden, CO 80401-3393

A national laboratory of the U.S. Department of Energy Managed by the Midwest Research Institute for the U.S. Department of Energy Under Contract No. DE-AC 36-83CH10093 


\section{Technical and Economic Assessment of Producing Hydrogen by Reforming Syngas from the Battelle Indirectly Heated Biomass Gasifier}

Margaret K. Mann

Industrial Technologies Division

National Renewable Energy Laboratory

Hydrogen Program Milestone Completion Report

Program Manager: Catherine Gregoire Padró

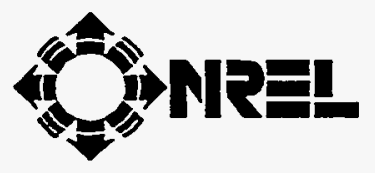

National Renewable Energy Laboratory 1617 Cole Boulevard

Golden, Colorado 80401-3393

A national laboratory of the U.S. Department of Energy managed by the Midwest Research Institute for the U.S. Department of Energy under Contract No. DE-AC36-83CH10093 


\section{NOTICE}

This report was prepared as an account of work sponsored by an agency of the United States government. Neither the United States government nor any agency thereof, nor any of their employees, makes any warranty, express or implied, or assumes any legal liability or responsibility for the accuracy, completeness, or usefulness of any information, apparatus, product, or process disclosed, or represents that its use would not infringe privately owned rights. Reference herein to any specific commercial product, process, or service by trade name, trademark, manufacturer, or otherwise does not necessarily constitute or imply its endorsement, recommendation, or favoring by the United States government or any agency thereof. The views and opinions of authors expressed herein do not necessarily state or reflect those of the United States government or any agency thereof.

Available to DOE and DOE contractors from:

Office of Scientific and Technical information (OSTI)

P.O. Box 62

Oak Ridge, TN 37831

Prices available by calling (615) 576-8401

Available to the public from:

National Technical Information Service (NTIS)

U.S. Department of Commerce

5285 Port Royal Road

Springfield, VA 22161

(703) $487-4650$ 


\section{DISCLAIMER}

Portions of this document may be illegible in electronic image products. Images are produced from the best available original document. 


\section{Executive Summary}

The technical and economic feasibility of producing hydrogen from biomass by means of indirectly heated gasification and steam reforming was studied. A detailed process model was developed in ASPEN Plus ${ }^{\mathrm{TM}}$ to perform material and energy balances. The results of this simulation were used to size and cost major pieces of equipment from which the determination of the necessary selling price of hydrogen was made. A sensitivity analysis was conducted on the process to study hydrogen price as a function of biomass feedstock cost and hydrogen production efficiency.

The gasification system used for this study was the Battelle Columbus Laboratory (BCL) indirectly heated gasifier. The heat necessary for the endothermic gasification reactions is supplied by circulating sand from a char combustor to the gasification vessel. Hydrogen production was accomplished by steam reforming the product synthesis gas (syngas) in a process based on that used for natural gas reforming. Three process configurations were studied. Scheme 1 is the full reforming process, with a primary reformer similar to a process furnace, followed by a high temperature shift reactor and a low temperature shift reactor. Scheme 2 uses only the primary reformer, and Scheme 3 uses the primary reformer and the high temperature shift reactor. A pressure swing adsorption (PSA) system is used in all three schemes to produce a hydrogen product pure enough to be used in fuel cells. Steam is produced through detailed heat integration and is intended to be sold as a by-product.

Three plant sizes, $27 \mathrm{~T} /$ day ( $30 \mathrm{t} /$ day), $272 \mathrm{~T} /$ day (300 t/day), and $907 \mathrm{~T} /$ day (1000 t/day) were studied. In Scheme 1, the small plant produces approximately 21,594 standard $\mathrm{m}^{3} /$ day $(762,580 \mathrm{scfd})$ hydrogen, which approximates the fuel requirement of 500 vehicles per day with a fuel economy corresponding to 60 miles per gallon of gasoline (Ogden, 1995). The medium-size plant was chosen for study because it is ten times larger. The large plant corresponds to a plant using half the maximum amount of biomass that has historically been considered to be economically and logistically feasible from a dedicated feedstock supply system (DFSS). The two smaller plants would most likely be able to use waste biomass at a cheaper price than that from a DFSS. When examples of costs are given in this report, biomass is assumed to cost $\$ 46.30 / T$ and $\$ 15 / T$ from DFSS and waste sources, respectively. The cost of biomass from either waste sources or a DFSS will vary depending on the location and crop type, as well as market influences once biomass energy systems are developed. The Department of Energy goal for biomass from a DFSS is $\$ 37.50 / \mathrm{T}(\$ 34 / \mathrm{t}=\$ 2 / \mathrm{MMBtu})$ to $\$ 46.30 / \mathrm{T}(\$ 42 / \mathrm{t}=$ $\$ 2.50 / \mathrm{MMBtu})$.

The steam reforming process studied is very similar to that used to reform natural gas. All necessary unit operations are commercially available, and should require no special engineering design. The estimated capital costs of the entire gasification and reforming plant for the most profitable scenario studied (Scheme 1) are $\$ 6.1$ million for the $27 \mathrm{~T}$ per day ( $30 \mathrm{t} /$ day) plant, $\$ 34.5$ million for the $272 \mathrm{~T} /$ day ( $300 \mathrm{t} /$ day) plant, and $\$ 90.4$ million for the $907 \mathrm{~T} /$ day (1000 t/day) plant.

The economics of producing hydrogen from this process are moderately favorable for many of the scenarios tested. The most economically feasible design is that tested in Scheme 1. The necessary selling price for hydrogen produced by steam reforming BCL biomass syngas falls within the current market values ( $\$ 5$ - $\$ 15 / G J)$ for many of the cost scenarios studied. However, the results are mostly on the high end of this range for reasonable biomass feedstock costs. Of the three plant sizes studied, the most economic configuration depends upon the availability of waste biomass at a lower price than biomass from a DFSS. If waste biomass can be

obtained for the medium size plant, this scale with a Scheme 1 design yields the lowest hydrogen price. If the medium size plant must use biomass from a DFSS, the large plant with a Scheme 1 design is the most economic. 
Results show that the small scale plant using any of the process schemes studied does not produce hydrogen cheaper than the medium size plant. However, if the small plant is the only size for which cheaper waste biomass can be obtained, local refueling stations, similar to existing gasoline stations, might be feasible.

The hydrogen production cost from the large plant obtaining biomass from a DFSS at $\$ 46.30 / \mathrm{T}(\$ 42 / \mathrm{t})$, is $\$ 6.50 / \mathrm{GJ}$ ( $\$ 6.90 / \mathrm{MMBtu})$ without taxes. With a $37 \%$ tax rate and a $15 \%$ after-tax internal rate of return (IRR), the necessary hydrogen selling price is $\$ 13.70 / \mathrm{GJ}(\$ 14.30 / \mathrm{MMBtu})$. The hydrogen production cost for the $272 \mathrm{~T} /$ day plant is $\$ 4.10 / \mathrm{GJ}$ using biomass waste at $\$ 16.50 / \mathrm{T}(\$ 15 / \mathrm{t})$. The corresponding hydrogen selling price is $\$ 13.10 / G \mathrm{~J}$ ( $\$ 13.80 / \mathrm{MMBtu})$. If the feedstock for the medium size plant must be obtained from a DFSS, the production cost and necessary selling price increases to $\$ 7.20 / \mathrm{GJ}(\$ 7.60 / \mathrm{MMBtu})$ and $\$ 16.20 / \mathrm{GJ}$ $(\$ 17.1 / \mathrm{MMBtu})$, respectively. Hydrogen produced in the small plant using waste biomass will cost $\$ 7.20 / \mathrm{GJ}$ (\$7.60/MMBtu), and sell for $\$ 23.20 / G J(\$ 24.50 / \mathrm{MMBtu})$. A lower specified IRR would decrease the required selling price in each case and the estimates of what biomass from waste and DFSS sources will cost are likely to vary from the examples given here. Hydrogen produced in process Schemes 2 and 3 is more expensive than that produced in Scheme 1 because of the decrease in production.

The discount rate for which the net present value of the project equals zero was calculated for each scenario studied. This rate is set such that the cumulative net earnings from the project exactly balance the initial investment in the process. Using Scheme 1, the discount rate for the large plant using biomass from a DFSS is 9.2\%. The rate for the medium plant using biomass from a DFSS is $6.7 \%$; using biomass waste, this rate increases to $10.4 \%$. The rate for the small plant, even with the cheaper biomass waste feedstock, is $4.0 \%$.

The break-even points for the large, medium, and small plants are 13.3 years, 6.3 years, and 7.2 years, respectively. These calculations were made using DFSS biomass for the large plant and waste biomass for the medium and small plants. If the medium plant must use biomass from a DFSS, the break-even point is extended to 9.5 years. 


\section{Table of Contents}

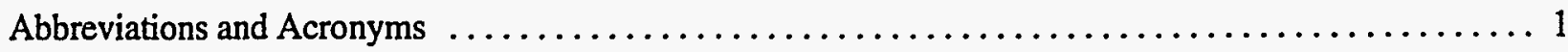

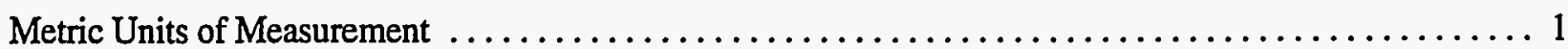

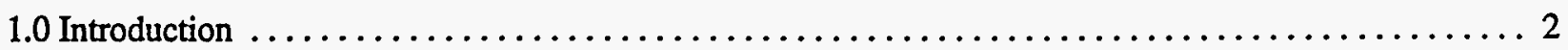

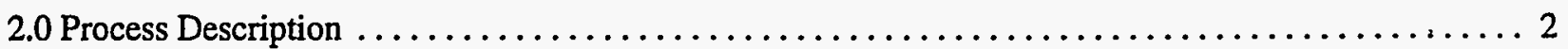

2.1 Gasification Using the BCL Indirectly Heated Gasifier $\ldots \ldots \ldots \ldots \ldots \ldots \ldots \ldots \ldots \ldots, \ldots \ldots \ldots$

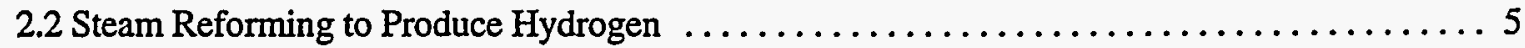

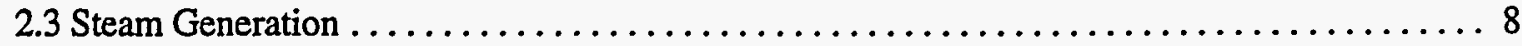

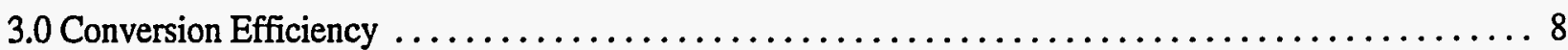

3.1 Stoichiometric Maximum Efficiency Calculation $\ldots \ldots \ldots \ldots \ldots \ldots \ldots \ldots \ldots \ldots$

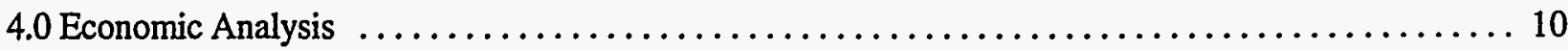

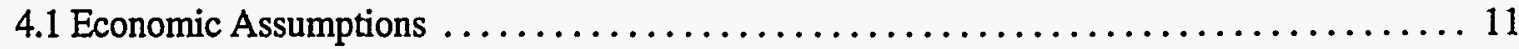

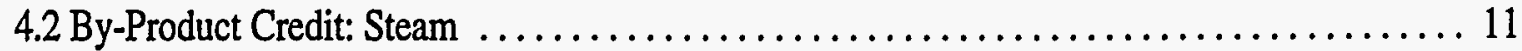

4.3 Equipment Sizing and Costing $\ldots \ldots \ldots \ldots \ldots \ldots \ldots \ldots \ldots \ldots \ldots \ldots \ldots \ldots \ldots \ldots \ldots \ldots \ldots \ldots, 12$

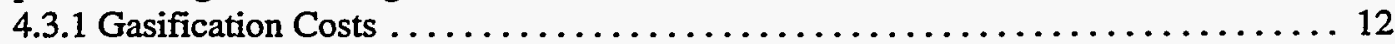

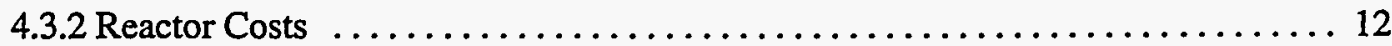

4.3.3 Compressor Costs .................................... 13

4.3.4 Heat Exchanger Costs $\ldots \ldots \ldots \ldots \ldots \ldots \ldots \ldots \ldots \ldots \ldots \ldots \ldots \ldots \ldots \ldots \ldots \ldots \ldots \ldots \ldots, 13$

4.3.5 Pump Costs ............................................ 13

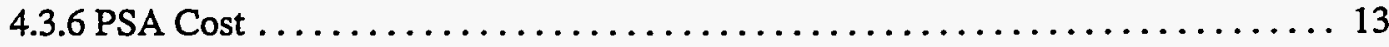

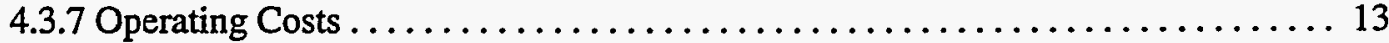

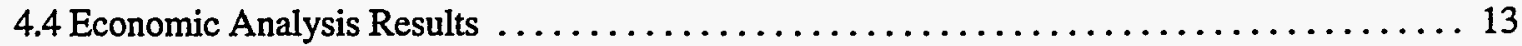

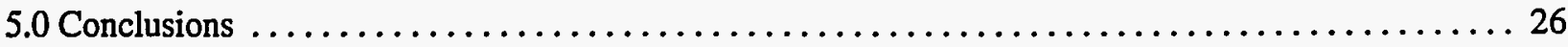

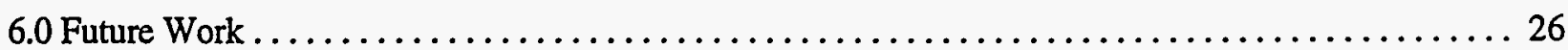

References and Pertinent Literature $\ldots \ldots \ldots \ldots \ldots \ldots \ldots \ldots \ldots \ldots \ldots \ldots \ldots \ldots \ldots \ldots \ldots \ldots \ldots \ldots \ldots, 28$ 


\section{List of Tables}

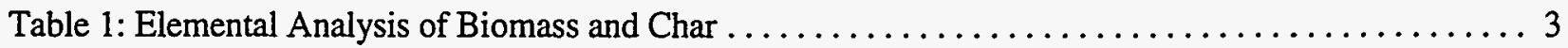

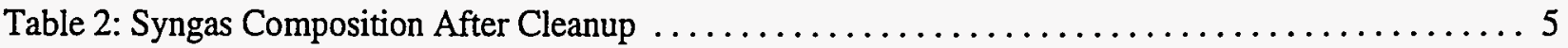

Table 3: Summary of Unit Operations Used in Different Process Configurations $\ldots \ldots \ldots \ldots \ldots \ldots \ldots 7$

Table 4: Hydrogen Produced in Each Scenario Analyzed (standard $\left.\mathrm{m}^{3} / \mathrm{day}\right) \ldots \ldots \ldots \ldots \ldots \ldots \ldots \ldots$

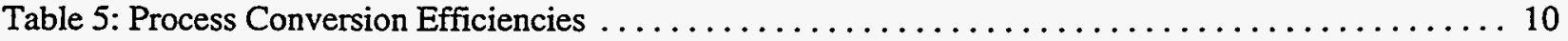

Table 6: Economic Assumptions . . . . . . . . . . . . . . . . . . . . . . . . . . . . . . . 11

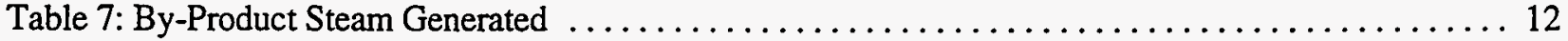

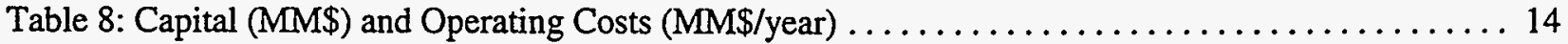

Table 9: Necessary Hydrogen Selling Price for a 15\% after-tax IRR After Taxes $\ldots \ldots \ldots \ldots \ldots \ldots 21$

Table 10: Discount Rate Obtained from Return on Investment Analysis $\ldots \ldots \ldots \ldots \ldots \ldots \ldots \ldots 22$

\section{List of Figures}

Figure 1: The Battelle Indirectly Heated Gasification System $\ldots \ldots \ldots \ldots \ldots \ldots \ldots \ldots \ldots \ldots$

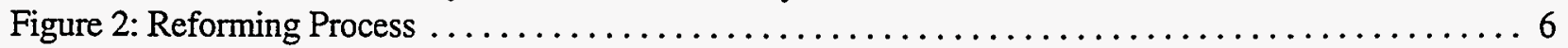

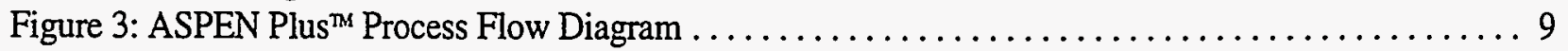

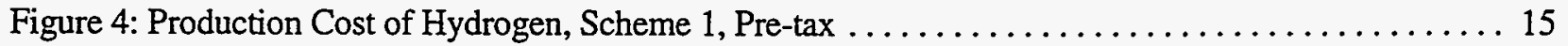

Figure 5: Selling Price of Hydrogen, Scheme 1, After-tax, 15\% IRR $\ldots \ldots \ldots \ldots \ldots \ldots \ldots \ldots \ldots$

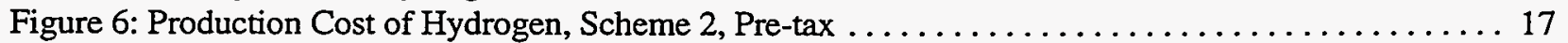

Figure 7: Selling Price of Hydrogen, Scheme 2, After-tax, $15 \% \operatorname{IRR} \ldots \ldots \ldots \ldots \ldots \ldots \ldots \ldots \ldots$

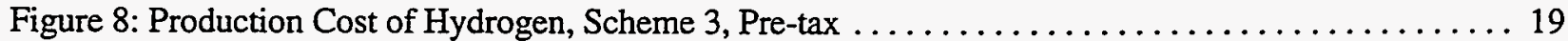

Figure 9: Selling Price of Hydrogen, Scheme 3, After-tax, $15 \%$ IRR $\ldots \ldots \ldots \ldots \ldots \ldots \ldots \ldots \ldots 20$

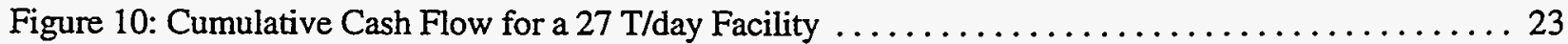

Figure 11: Cumulative Cash Flow for a $272 \mathrm{~T} /$ day Facility . . . . . . . . . . . . . . . . . . . 24

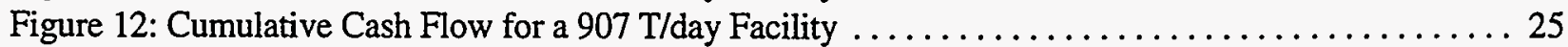




\section{Abbreviations and Acronyms}

BCL - Battelle Columbus Laboratories

CO - Carbon monoxide

$\mathrm{CO}_{2}$ - Carbon dioxide

DCFROR - Discounted Cash Flow Rate of Return

DFSS - Dedicated Feedstock Supply System

GJ - Gigajoule

$\mathrm{H}_{2}$ - Hydrogen

IRR - Internal Rate of Return

$\mathrm{kPa}$ - Kilopascal

MMBtu - Million British Thermal Units

PSA - Pressure Swing Adsorption

ROI - Return on Investment

SCFD - Standard Cubic Feet.per Day

$\mathrm{t}$ - ton

T-Metric tonne

\section{Metric Units of Measurement}

In accord with recommendations from the Department of Energy, all results from this study are reported in metric units. Occasionally, the English system equivalent is stated in parenthesis. Below are the metric units used in this report with the corresponding conversions to English units.

Mass: $\quad$ kilogram $(\mathrm{kg})=2.20462$ pounds

metric tonne $(\mathrm{T})=1.10231$ ton

Volume: $\quad$ cubic meter $\left(\mathrm{m}^{3}\right)=264.17$ gallons

Pressure: $\quad$ kilopascals $(\mathrm{kPa})=0.145$ pounds per square inch

Energy: $\quad$ gigajoule $(\mathrm{GJ})=0.9488 \mathrm{MMBtu}$

Temperature: $\quad{ }^{\circ} \mathrm{C}=\left({ }^{\circ} \mathrm{F}-32\right) / 1.8$ 


\subsection{Introduction}

The technical and economic feasibility of producing hydrogen by reforming syngas from the Battelle Columbus Laboratory (BCL) indirectly heated gasifier was studied. From experimental work conducted at BCL on the gasifier and commercial information on the reforming operation, a process plant was designed using the ASPEN Plus $^{\mathrm{TM}}$ simulation software. The material and energy balances obtained were used to size and cost major pieces of equipment, from which a capital cost estimation was made. Using discounted cash flow rate of return (DCFROR) and return on investment (ROI) analyses, the economic position of this biomass-derived process relative to conventional hydrogen production processes was assessed.

Hydrogen has the potential to deliver significant economic and environmental benefits. Hydrogen is a very clean burning fuel; in internal combustion engines, water and a very small amount of $\mathrm{NO}_{\mathrm{x}}$ are the only products. When used in a fuel cell to produce electricity, water is the sole product. Hydrogen can be used to produce energy in every application that fossil fuels are currently used. By 2025, the percentage of energy from oil imports could be reduced from the current $50-60 \%$ to less than $25 \%$, if hydrogen energy were only to contribute $10 \%$ to the overall energy use.

On a life-cycle basis, the emissions associated with hydrogen depend primarily upon the production route used. Renewable resources, such as solar, wind, and biomass are excellent feedstocks for hydrogen because of their inherently clean nature and sustainability.

This study assesses the technical design and economic feasibility of producing hydrogen from gasification, one of the possible biomass-based routes to hydrogen. Biomass is considered to be anything that has participated in the growing cycle recently. Agriculture waste, forest residue, urban wood waste, and trees and grasses grown as energy crops, are commonly the process feedstocks referred to as biomass. Because biomass consumes as much $\mathrm{CO}_{2}$ in its growing cycle as is produced when it is transformed to energy, the net $\mathrm{CO}_{2}$ contribution from biomass-derived fuels to the atmosphere is much less than from fossil-derived fuels. Furthermore, producing biomass on a sustainable basis by growing energy crops supports the U.S. agriculture sector and potentially reduces our oil and gas imports.

The gasification system used for this study was the BCL indirectly heated gasifier. The heat necessary for the endothermic gasification reactions is supplied by circulating sand from a char combustor to the gasification vessel. The syngas, containing primarily $\mathrm{CO}, \mathrm{H}_{2}, \mathrm{CH}_{4}, \mathrm{CO}_{2}$, and some higher hydrocarbons, is then steam reformed to produce $\mathrm{H}_{2}$ and $\mathrm{CO}_{2}$ in a process based on that used for natural gas reforming. The $\mathrm{H}_{2} \mathrm{H}$ can be purified and sold as an energy carrier to be used in vehicles, power plants, or refinery applications.

\subsection{Process Description}

Biomass, obtained either from a DFSS, or as agricultural, urban, or industrial waste, is fed to a rotary dryer to reduce the moisture content from approximately $50 \%$ to $11 \%$. The biomass is then gasified in the BCL gasifier which is heated indirectly by sand circulating between a char combustor and the gasification vessel. The product syngas is cooled and compressed to the appropriate conditions for reforming. A reactor known as the primary reformer converts the methane and higher hydrocarbons to $\mathrm{CO}$ and performs a significant portion of the water-gas shift reaction to convert $\mathrm{CO}$ and water to $\mathrm{H}_{2}$ and $\mathrm{CO}_{2}$. The remaining $\mathrm{CO}$ is consumed via this reaction in the subsequent high temperature and low temperature shift reactors. A pressure swing adsorption (PSA) system is used to separate hydrogen pure enough for use in fuel cell applications from the shift reactors product gas. 


\subsection{Gasification Using the BCL Indirectly Heated Gasifier}

A schematic of the BCL gasifier is shown in Figure 1. This system was simulated using run data from Battelle Columbus Laboratory. A Fortran subroutine controls the simulation of the gasifier and is shown along with the entire run input file in Appendix A. Biomass and char were simulated as non-conventional components; their ultimate analyses are shown in Table 1 . The biomass composition used for this study is typical of woody biomass such as hybrid poplar.

Table 1: Elemental Analysis of Biomass and Char

\begin{tabular}{|c|c|c|}
\hline & \multicolumn{2}{|c|}{$\begin{array}{l}\text { Ultimate Analysis } \\
\text { (Weight percent, dry basis) }\end{array}$} \\
\hline & Biomass & Char \\
\hline Carbon & 50.88 & 65.2 \\
\hline Oxygen & 41.90 & 3.03 \\
\hline Hydrogen & 6.04 & 3.70 \\
\hline Nitrogen & 0.17 & 2.47 \\
\hline Sulfur & 0.09 & 28.65 \\
\hline Chlorine & 0 & 0 \\
\hline Ash & 0.92 & 3.04 \\
\hline
\end{tabular}

Biomass of approximately $50 \mathrm{wt} \%$ moisture is dried in a rotary drier using a combination of char combustor flue gas and air. The dried biomass, containing $11 \mathrm{wt} \%$ moisture, is fed to the fluidized bed gasifier, with hot sand from the char combustor as the bed material. It operates at nearly atmospheric pressure and $825^{\circ} \mathrm{C}\left(1517^{\circ} \mathrm{F}\right)$. Steam rather than air or oxygen is added to the gasifier to produce a syngas of medium quality: $18.35 \mathrm{MJ} / \mathrm{m}^{3}$ (493 $\mathrm{Btu} / \mathrm{scf}$ ). After a cyclone separator removes the char, the syngas is expected to be cleaned using the hot-gas clean-up processes currently being developed by the Department of Energy (DOE) and Westinghouse; the current technology uses a water scrubber. Hot-gas clean-up would consist of ceramic candle filters to remove particulates from the syngas prior to downstream operations such as reforming. The resultant syngas composition is shown in Table 2. 
Figure 1: The Battelle Indirectly Heated Gasification System

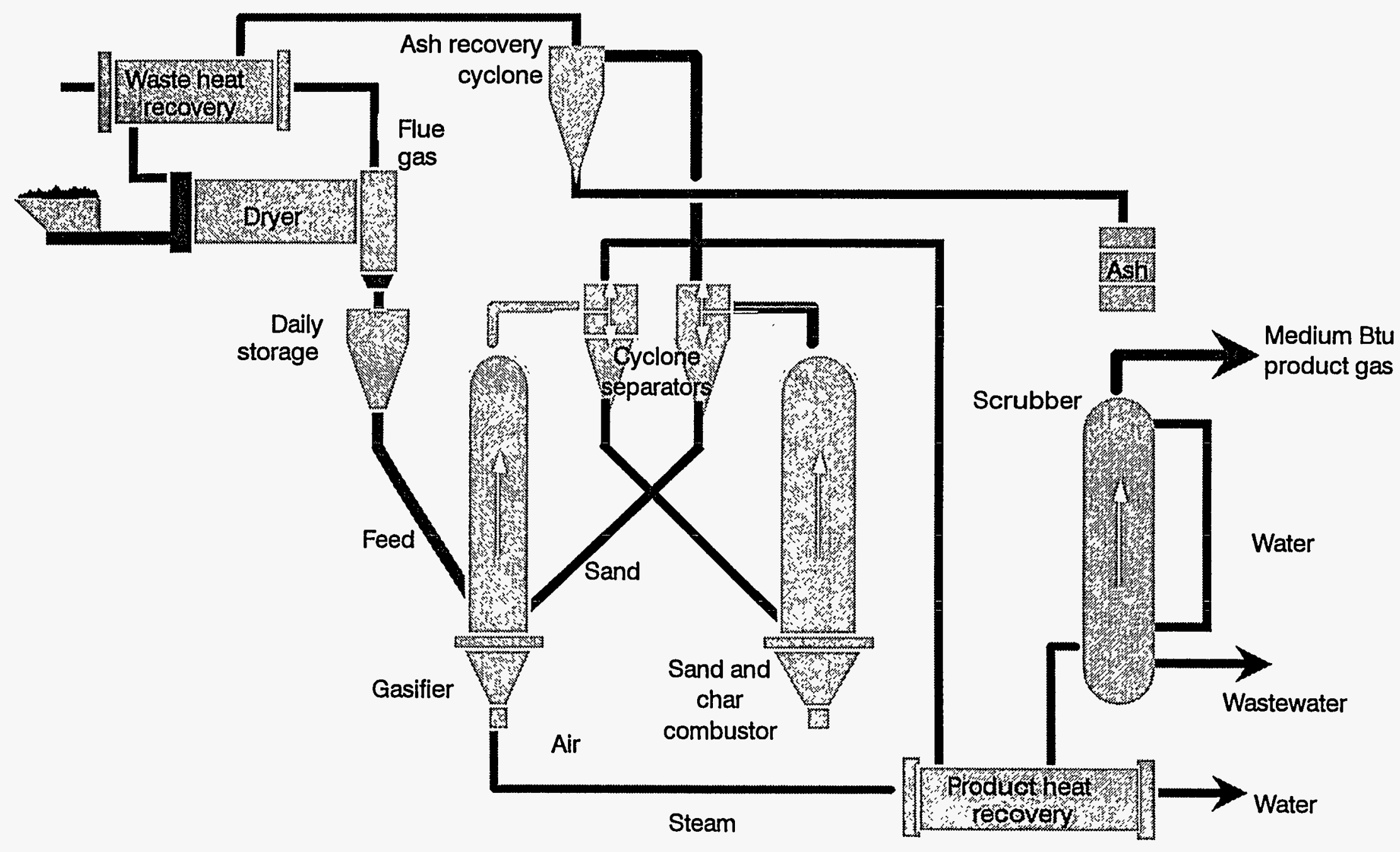


Table 2: Syngas Composition After Cleanup

\begin{tabular}{|l|l|}
\hline Component & Volume\% \\
\hline $\mathrm{CO}$ & $43.17 \%$ \\
\hline$\dot{\mathrm{H}}_{2}$ & $21.22 \%$ \\
\hline $\mathrm{CH}_{4}$ & $15.83 \%$ \\
\hline $\mathrm{CO}_{2}$ & $13.46 \%$ \\
\hline $\mathrm{C}_{2} \mathrm{H}_{4}$ & $4.62 \%$ \\
\hline $\mathrm{C}_{2} \mathrm{H}_{6}$ & $0.47 \%$ \\
\hline $\operatorname{tar}$ & $0.40 \%$ \\
\hline $\mathrm{C}_{2} \mathrm{H}_{2}$ & $0.37 \%$ \\
\hline $\mathrm{NH}_{3}$ & $0.37 \%$ \\
\hline $\mathrm{H}_{2} \mathrm{~S}$ & $0.08 \%$ \\
\hline
\end{tabular}

After clean-up, the syngas is cooled to $91^{\circ} \mathrm{C}\left(195^{\circ} \mathrm{F}\right)$ so that it can be compressed to the pressure required for the PSA system plus the expected pressure losses in the reactors. During this cooling, the water and higher hydrocarbons (tars) remaining in the syngas will most likely condense and must be removed and pumped before being added again to the compressed syngas. The syngas compressor outlet pressure is $3,654 \mathrm{kPa}$ (530 psi).

\subsection{Steam Reforming to Produce Hydrogen}

The reforming process, shown in Figure 2, is similar to that used in hydrogen production from natural gas. The major unit operations are a primary reformer to convert methane and the higher hydrocarbons present in the syngas to hydrogen, plus shift reactors to convert $\mathrm{CO}$ to hydrogen. The reactions governing the reforming process are shown in the following equations:

$$
\mathrm{C}_{\mathrm{n}} \mathrm{H}_{\mathrm{m}}+\mathrm{nH}_{2} \mathrm{O}+\text { heat } \Rightarrow \mathrm{nCO}+(\mathrm{m} / 2+\mathrm{n}) \mathrm{H}_{2}
$$

$$
\mathrm{CO}+\mathrm{H}_{2} \mathrm{O} \Rightarrow \mathrm{CO}_{2}+\mathrm{H}_{2}+\text { heat }
$$

The primary reformer, a reactor similar to a process furnace with catalyst-filled tubes, converts the methane and higher hydrocarbons to $\mathrm{CO}$ and $\mathrm{H}_{2}$ (Reaction 1 ), and performs a significant portion of the water-gas shift reaction to convert $\mathrm{CO}$ and water to $\mathrm{H}_{2}$ and $\mathrm{CO}_{2}$ (Reaction 2). The remaining $\mathrm{CO}$ is consumed via this reaction in the subsequent high temperature and low temperature shift reactors. A pressure swing adsorption (PSA) system is used to purify the hydrogen.

Reaction (1) typically takes place at temperatures between $800^{\circ} \mathrm{C}$ and $850^{\circ} \mathrm{C}\left(1472^{\circ} \mathrm{F}\right.$ and $\left.1561^{\circ} \mathrm{F}\right)$ in the primary reformer. The heat necessary for this endothermic reaction is supplied by combusting the PSA offgas outside of the reactor tubes through which the reactants and products are flowing. These tubes are filled with a commercial nickel-based catalyst. According to results from operating plants, the primary reformer was 
Figure 2: Reforming Process

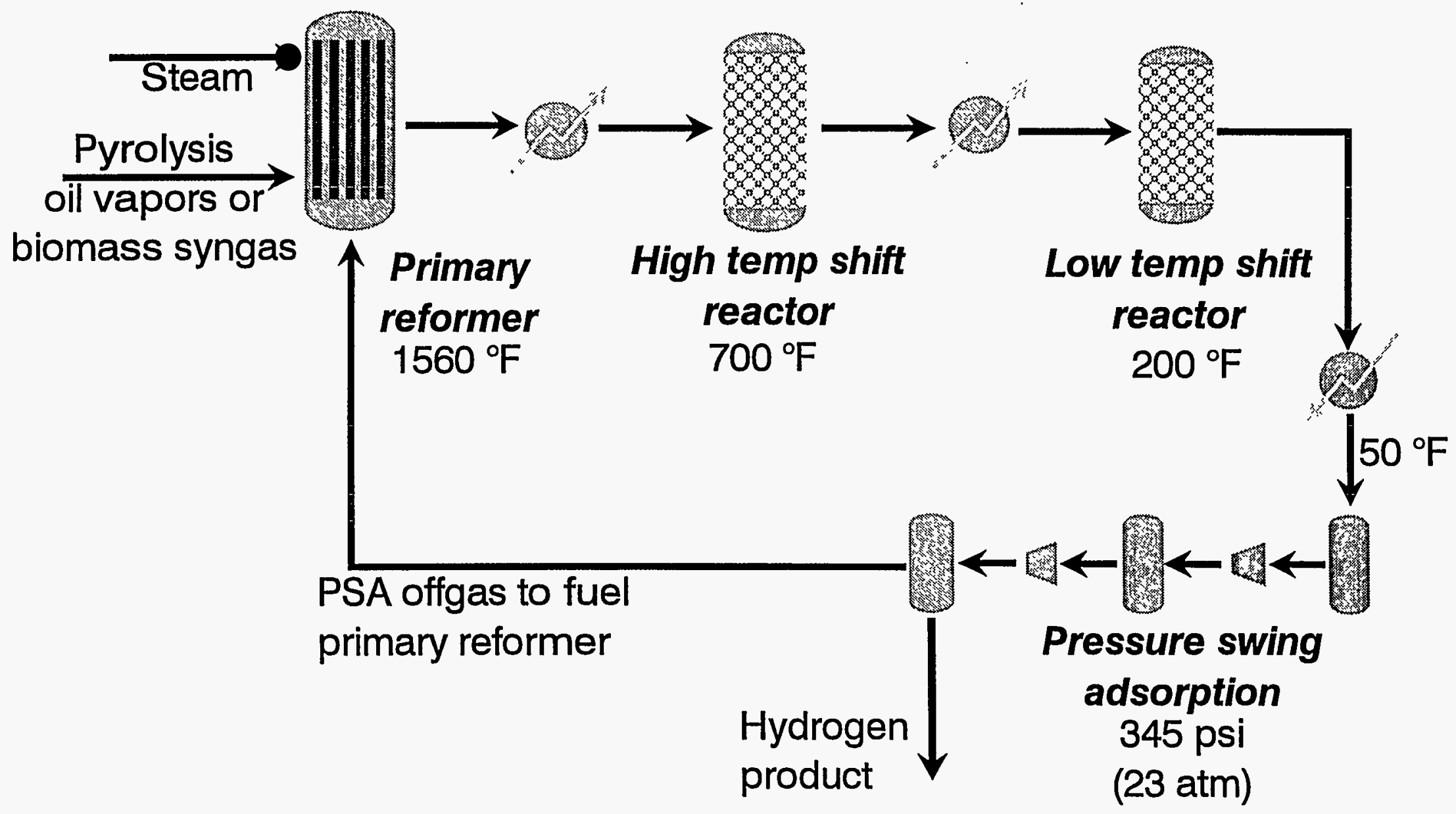


simulated as an equilibrium reactor with an $11^{\circ} \mathrm{C}$ approach temperature (Tindall and King, 1991). Reaction (2) is the water-gas shift reaction. According to the thermodynamics of the reforming process, practically all of the tar and $\mathrm{C}_{2} \mathrm{H}_{x}$ species are consumed, $60 \mathrm{~mol} \%$ of the $\mathrm{CH}_{4}$ is converted, and there is a $22 \mathrm{~mol} \%$ net conversion of CO.

Because reaction (2) is exothermic, it is beneficial to convert the remaining $\mathrm{CO}$ at a temperature lower than the temperature of the primary reformer. Nearly complete conversion of $\mathrm{CO}$ is accomplished in the subsequent high and low temperature shift reactors. The feed to the high temperature shift reactor is cooled to $370^{\circ} \mathrm{C}\left(698^{\circ} \mathrm{F}\right)$ and increases to $435^{\circ} \mathrm{C}\left(814^{\circ} \mathrm{F}\right)$ as the water-gas shift reaction proceeds. The product of this reactor is then cooled to $200^{\circ} \mathrm{C}\left(392^{\circ} \mathrm{F}\right)$ and fed to the low temperature shift reactor that produces a gas at $220^{\circ} \mathrm{C}\left(430^{\circ} \mathrm{F}\right)$ with a drybasis composition of $61.9 \% \mathrm{H}_{2}, 34.1 \% \mathrm{CO}_{2}, 2.9 \% \mathrm{CH}_{4}$, and $1.1 \% \mathrm{CO}$.

A steam-to-carbon ratio of three was used for the reforming operations. This is consistent with that used for natural gas reforming. However, higher hydrocarbon feedstocks may require additional steam (Tindall and King, 1991). The higher content of CO in syngas should improve the kinetics of this process over steam reforming natural gas. However, reforming the $\mathrm{C}_{2}$ and higher compounds could prove more difficult. Actual experimental data will dictate the appropriate steam-to-carbon ratio. The process studied has a great deal of excess heat available from which steam will be produced for export; therefore, a higher reforming steam requirement will not greatly affect the economics of the process.

Before the reformer product stream can be purified in a PSA unit, it must contain at least 70 mol\% hydrogen (Anand, 1995). Purifying streams more dilute than this decreases the purity and recovery of the hydrogen. Therefore, part of the PSA product stream is recycled back into the PSA feed. The recovery of hydrogen in the PSA is $85 \%$ when purifying a $70 \mathrm{~mol}_{2} \mathrm{H}_{2}$ stream. The incorporation of the recycle loop decreases the overall separation recovery to $77 \%$. The operating pressure of the PSA unit is $2,500 \mathrm{kPa}$ (363 psi).

Three process configurations, or schemes, were studied. Scheme 1 uses all reforming operations typically used in natural gas reforming: the primary reformer, the high temperature shift reactor, and the low temperature shift reactor. Scheme 2 uses only the primary reformer, and Scheme 3 uses the primary reformer and the high temperature shift reactor. All schemes use identical gasification and hydrogen purification processes. Schemes 2 and 3 were studied to assess the profitability of the process if the capital requirements could be lowered at the expense of producing less hydrogen. Because these process configurations are referred to throughout the report as Schemes 1,2, and 3, Table 3 gives a description of each for easy reference.

Table 3: Summary of Unit Operations Used in Different Process Configurations

\begin{tabular}{|c|l|}
\hline Scheme & Reforming operations used \\
\hline 1 & Primary reformer, high temperature shift reactor, low temperature shift reactor \\
\hline 2 & Primary reformer \\
\hline 3 & Primary reformer, high temperature shift reactor \\
\hline
\end{tabular}




\subsection{Steam Generation}

In the simulation, gasification and reforming were integrated such that heat available from the reforming operation could generate the steam necessary for gasification as well as a substantial amount of export steam. The process gas was cooled as it moved between the primary reformer, the shift reactors, and the PSA unit, generating steam in each step. Steam was also generated by cooling the primary reformer flue gas. The majority of the steam produced was superheated at $690 \mathrm{kPa}$ (100 psig); the steam produced by cooling the process gas between the high and low temperature shift reactors was at $3,450 \mathrm{kPa}(500 \mathrm{psig})$.

A complete process flow diagram corresponding to the simulation is shown in Figure 3. Appendix $\mathrm{C}$ contains stream data for the $907 \mathrm{~T} /$ day plant.

\subsection{Conversion Efficiency}

Two methods were used to estimate the efficiency of producing hydrogen from biomass by this process. The first method looks at the ratio of the amount of hydrogen that was produced to the stoichiometric maximum amount of hydrogen possible according to reactions (1) and (2). The second method calculates the ratio of the energy value of the product hydrogen and export steam to the energy value of the biomass feed plus purchased electricity. The amount of hydrogen produced for each plant size and scheme is shown in Table 4.

Table 4: Hydrogen Produced in Each Scenario Analyzed (standard $\mathrm{m}^{3} / \mathrm{day}$ )

\begin{tabular}{|l|l|l|l|}
\hline & Scheme 1 & Scheme 2 & Scheme 3 \\
\hline 27 T/day biomass & 21,600 & 16,850 & 20,440 \\
\hline 272 T/day biomass & 215,940 & 168,500 & 204,390 \\
\hline 907 T/day biomass & 719,800 & 561,650 & 681,280 \\
\hline
\end{tabular}

\subsection{Stoichiometric Maximum Efficiency Calculation}

The "molecular formula" of biomass can be approximated as $\mathrm{CH}_{1.47} \mathrm{O}_{0.67}$ on a dry basis. Completely steam reforming this biomass yields 2.07 moles of hydrogen per "mole" of biomass as shown by the following stoichiometry:

$$
\mathrm{CH}_{1.47} \mathrm{O}_{0.67}+1.33 \mathrm{H}_{2} \mathrm{O} \Rightarrow \mathrm{CO}_{2}+2.07 \mathrm{H}_{2}
$$

This hydrogen yield is equivalent to 2.02 standard $\mathrm{m}^{3}$ hydrogen $/ \mathrm{kg}$ biomass ( $32.38 \mathrm{scf} / \mathrm{lb}$ ). In Scheme 1 , with all reforming operations used, 0.79 standard $\mathrm{m}^{3} / \mathrm{kg}(12.71 \mathrm{scf} / \mathrm{lb})$ hydrogen is produced. This corresponds to a $39.3 \%$ conversion and recovery efficiency. 


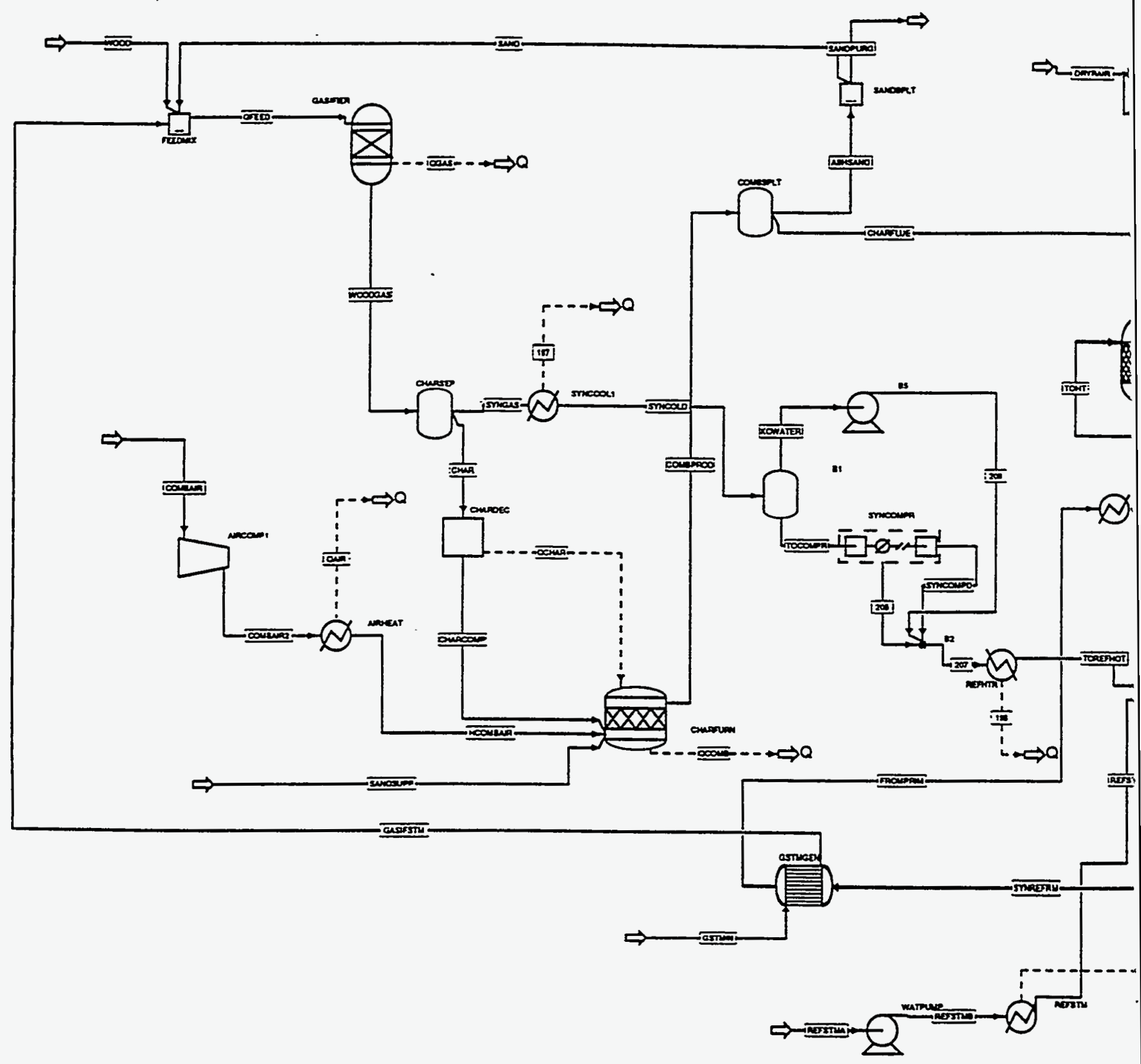




\subsection{Energy Conversion Efficiency Calculation}

The efficiency of this process on an energy in, energy out basis can be calculated by the following formula:

$$
\frac{\left(\mathrm{H}_{2}\right)\left(\mathrm{HHV}_{\mathrm{H} 2}\right)+\left(\mathrm{stm}_{\mathrm{ex}}\right)\left(\Delta \mathrm{H}_{\mathrm{h}}\right)}{\left(\mathrm{B}_{\mathrm{f}}\right)\left(\mathrm{HHV}_{\mathrm{b}}\right)+e}
$$

where: $\quad \mathrm{H}_{2}=$ hydrogen recovered $(\mathrm{kg})$

$\mathrm{HHV}_{\mathrm{H} 2}=$ higher heating value of hydrogen $(\mathrm{GJ} / \mathrm{kg})$

$\Delta \mathrm{H}_{\mathrm{sh}}=$ difference in enthalpy between incoming water and steam produced (GJ)

$\mathrm{stm}_{\mathrm{ex}}=$ steam produced to be sold $(\mathrm{kg})$

$\mathrm{B}_{\mathrm{f}}=$ biomass fed to process $(\mathrm{kg})$

$\mathrm{HHV}_{\mathrm{b}}=$ higher heating value of biomass $(19.75 \mathrm{MJ} / \mathrm{kg}=8,500 \mathrm{Btu} / \mathrm{lb})$

$\mathrm{e}=$ electricity imported for process requirements ( $\mathrm{GJ}$ equivalent)

The efficiencies calculated for the three schemes are shown in Table 5.

Table 5: Process Conversion Efficiencies

\begin{tabular}{|l|c|c|}
\hline & Stoichiometric Efficiency & Energy Conversion Efficiency \\
\hline Scheme 1 & $39.3 \%$ & $79.0 \%$ \\
\hline Scheme 2 & $30.6 \%$ & $69.7 \%$ \\
\hline Scheme 3 & $37.2 \%$ & $76.5 \%$ \\
\hline
\end{tabular}

\subsection{Economic Analysis}

The current market value of hydrogen is between $\$ 5$ and $\$ 15 / G J$. By calculating the economics of the process being studied and comparing the results to this current hydrogen market, the potential profitability can be assessed. Possible sources of error in this analysis are in equipment cost estimation, feedstock and product market predictions, and invalid economic assumptions. The total error can be reduced by looking at ranges of profitability, such as the range of hydrogen selling price versus a range of biomass feedstock costs. As more information on the development of biomass-based technologies becomes available, this analysis can be modified to give a more representative process cost.

The economic feasibility of producing hydrogen by steam reforming syngas from the BCL gasifier was studied using the DCFROR method. This method calculates the IRR that will be earned on the initial capital investment over the life of the project. Given this rate and a feedstock cost, the necessary selling price of the product can be calculated. Often, the IRR is specified as the minimum acceptable rate for an investor to finance a project. Therefore, the perceived risk of the project can be incorporated into the IRR. Because the process of producing hydrogen from biomass currently carries higher risks than conventional hydrogen-generating processes, the IRR specified in this study was $15 \%$ after tax, while the rate for conventional processes is between $9 \%$ and $12 \%$. For a $37 \%$ tax rate, a $15 \%$ after-tax IRR corresponds to a pre-tax IRR of $20.3 \%$. 
As an alternative means of measuring the economic feasibility of this process, an ROI analysis was also performed. The ROI is the sum of the net present value of each project year's revenue, divided by the initial capital investment. The discount rate used to bring all revenues and costs to the value of what money is worth today (or at any defined time) is set so that the ROI equals zero. This practice is also known as setting the net present value equal to zero.

\subsection{Economic Assumptions}

The economic analysis for this study was based on current dollars and performed using equity financing, assuming that the capital will not be borrowed. The latter assumption is probably valid for the smaller-scale plants, less so for the large plant. The majority of the assumptions used in performing the economic analysis are shown in Table 6. Other assumptions, such as the percentage of the purchased equipment cost spent on piping, can be found in the cost sheets in Appendix B.

Table 6: Economic Assumptions

\begin{tabular}{|l|}
\hline January, 1995 dollars \\
\hline Equity financing \\
\hline 20 year plant life \\
\hline Two year construction period \\
\hline $90 \%$ on-line factor \\
\hline Royalties $=0.5 \%$ of sales \\
\hline Inflation rate $=5 \%$ \\
\hline Tax rate $=37 \%$ \\
\hline Straight-line depreciation for ten years; first and last year at $50 \%$ of other years \\
\hline $50 \%$ plant capacity first year of production \\
\hline $30 \%$ of capital investment spent first year, $70 \%$ second year \\
\hline
\end{tabular}

\subsection{By-Product Credit: Steam}

A by-product credit was taken for the steam generated in the process. A selling price of $\$ 7.88 / 1000 \mathrm{~kg}$ $(\$ 3.57 / 1000 \mathrm{lb})$ was assumed for $3,450 \mathrm{kPa}(500 \mathrm{psig})$ steam. A price of $\$ 5.18 / 1000 \mathrm{~kg}(\$ 2.35 / 1000 \mathrm{lb})$ was assumed for $690 \mathrm{kPa}(100 \mathrm{psig})$ steam (Peters and Timmerhaus, 1980). All steam produced contains $17^{\circ} \mathrm{C}$ superheat. The amount of steam produced is shown in Table 7. The amount of steam generated for Schemes 2 and 3 is not expected to be significantly different from that generated in Scheme 1 because the same or higher amount of heat will be available. The assumption that the steam will be able to be sold is probably valid for the medium and large plants as they will most likely be located in more industrialized centers to take advantage of other infrastructure. However, it may be difficult to sell the steam produced by the small plant, as this size represents small refueling stations located near the demand for hydrogen. 
Table 7: By-Product Steam Generated

\begin{tabular}{|l|c|l|}
\hline Source of Heat (stream name in Figure 3) & $\begin{array}{l}\text { Amount Produced, } \\
\mathrm{kg} \text { steam } / \mathrm{kg} \text { dry biomass }\end{array}$ & $\begin{array}{l}\text { Pressure, } \mathrm{kPa} \\
\text { (psig) }\end{array}$ \\
\hline $\begin{array}{l}\text { Cooling gas between high and low temperature shift } \\
\text { (FROMHT) }\end{array}$ & 0.32 & $3,450(500)$ \\
\hline Compression of syngas (TOCOMPR) & 1.26 & $690(100)$ \\
\hline Compression of air fed to offgas combustor (OFFAIR1) & 0.12 & $690(100)$ \\
\hline Cooling offgas combustor flue gas (OFFFLUE) & 0.43 & $690(100)$ \\
\hline Cooling gas going to PSA (TOPSA) & 0.85 & $690(100)$ \\
\hline
\end{tabular}

\subsection{Equipment Sizing and Costing}

The material and energy balance results from the ASPEN Plus ${ }^{\mathrm{TM}}$ simulation were used to determine the size and corresponding costs of major pieces of equipment for the process. Costs were taken from the ChemCost software package and published literature and brought to January 1995 dollars using equipment cost escalation ratios from Chemical Engineering Magazine (March, 1995). Some costs, especially those related to gasification, were taken from other studies. Detailed cost results can be found in the cost sheets in Appendix B.

\subsubsection{Gasification Costs}

The cost of the gasification train was estimated in a previous study for DOE's Biomass Power Program, as well as by several consulting firms working for BCL (Breault and Morgan, 1992; Double, 1988; Dravo Engineering Companies, 1987; Weyerhaeuser, 1992). These costs were scaled to the appropriate plant size for this study using a 0.7 scale factor. Unit operations included in these costs were the feed system, dryer, gasifier, char combustor, cyclone separators, hot-gas cleanup system, and necessary pumps and compressors. The gasification steam generator (heat exchanger and flash drum) cost was calculated separately and included with the reformer costs.

\subsubsection{Reactor Costs}

The reactors sized and priced for this study were the primary reformer, the high temperature shift reactor, and the low temperature shift reactor.

A thermodynamically-controlled reactor block was used to model the primary reformer in ASPEN Plus ${ }^{\mathrm{TM}}$. This block predicts the final reaction products based on minimization of Gibbs free energy. An $11^{\circ} \mathrm{C}$ temperature approach to equilibrium was used in accordance with results from natural gas reforming operations (Tindall and King 1991). The heat for the endothermic reactions (Reaction 1) taking place in this reactor was supplied by burning the PSA offgas that consists of unrecovered hydrogen, $\mathrm{CH}_{4}, \mathrm{CO}$ and inerts. An equilibrium block was also used to model this combustor, and taken together, the two reactor blocks represent the primary reformer. The cost of the primary reformer was based on a furnace reactor, taken from three sources and averaged (see Appendix B cost sheets). 
The costs of the high and low temperature shift reactors were based on a space velocity of $4000 / \mathrm{hr}$ (Kirk-Othmer,

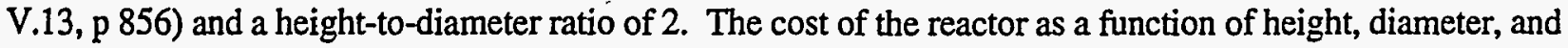
material of construction was determined using ChemCost. Costs from other sources were similar.

\subsubsection{Compressor Costs}

The two compressors necessary for this process are the syngas compressor and the air compressor for the offgas combustor. Both are four stage compressors with interstage cooling. As noted in Table 7, steam is generated by cooling the gas being compressed between stages. The costs of these compressors were calculated by ChemCost as eight individual compressors of the required horsepower. See cost sheets in Appendix B for the power requirements and resultant costs. The interstage coolers were calculated separately as heat exchangers and flash drums.

\subsubsection{Heat Exchanger Costs}

Heat exchangers were modeled as counter-current in the simulation. The minimum approach temperature used was $11^{\circ} \mathrm{C}$. The required area for a heat exchanger was calculated from the appropriate heat duty, temperature difference, and heat transfer coefficient. ChemCost was used to derive the corresponding cost.

\subsubsection{Pump Costs}

The cost of each pump required for the process was calculated by ChemCost using the flowrate and outlet pressure.

\subsubsection{PSA Cost}

The appropriate PSA design is very specific to the application, therefore, the manufacturers would most likely design and cost it for the potential buyer. Because this study is only to assess feasibility and not to design a planned operation, the capital and operating costs of the PSA unit were taken from the literature (Schendel, et $\mathrm{al}, 1983$ ) and scaled according to the amount of hydrogen produced. The installed capital of a PSA system was $\$ 7.164 /$ thousand standard $\mathrm{m}^{3} / \mathrm{d}$ ( $\$ 253 /$ thousand scfd). The operating costs were $\$ 0.184 /$ thousand standard $\mathrm{m}^{3} / \mathrm{d}$ (\$6.50/thousand scfd).

\subsubsection{Operating Costs}

Operating costs for this process include the feedstock, electricity to run the compressors $(\$ 0.05 / \mathrm{kWh})$, water for steam generation and cooling $\left(\$ 330 / \mathrm{m}^{3}\right)$, and labor. The revenue from steam produced for export is taken as an operating cost credit. Detailed operating costs for each plant can be found in the cost sheets in Appendix B.

\subsection{Economic Analysis Results}

The capital and operating costs for each of the scenarios studied are shown in Table 8 . These costs were calculated using a feedstock cost of $\$ 16.50 / \mathrm{T}$ for the small and medium size plants and $\$ 46.30 / \mathrm{T}$ for the large plant. Operating costs would increase significantly if the medium size plant obtained its biomass from a DFSS. 
Table 8: Capital (MM\$) and Operating Costs (MM\$/year)

\begin{tabular}{|l|r|r|r|r|r|r|r|r|r|}
\hline & \multicolumn{3}{|c|}{ Scheme 1 } & \multicolumn{3}{c|}{ Scheme 2 } & \multicolumn{3}{c|}{ Scheme 3 } \\
\hline Plant size & \multicolumn{1}{|c|}{$\mathrm{sm}$} & \multicolumn{1}{c|}{ med } & \multicolumn{1}{c|}{$\mathrm{lg}$} & $\mathrm{sm}$ & $\mathrm{med}$ & \multicolumn{1}{c|}{$\mathrm{lg}$} & $\mathrm{sm}$ & $\mathrm{med}$ & $\mathrm{lg}$ \\
\hline Operating Costs & 0.30 & 1.73 & 14.1 & 0.28 & 1.43 & 13.1 & 0.31 & 4.39 & 14.1 \\
\hline Fixed & 0.15 & 0.27 & 0.33 & 0.16 & 0.27 & 0.33 & 0.16 & 0.27 & 0.33 \\
\hline Variable & 0.16 & 1.60 & 5.33 & 0.13 & 1.30 & 4.32 & 0.16 & 1.60 & 5.32 \\
\hline Byproduct credit & -0.16 & -1.62 & -5.38 & -0.16 & -1.62 & -5.38 & -0.16 & -1.62 & -5.38 \\
\hline Feed & 0.15 & 1.48 & 13.8 & 0.15 & 1.48 & 13.8 & 0.15 & 4.14 & 13.8 \\
\hline Capital Costs & 6.08 & 34.5 & 90.4 & 5.05 & 29.3 & 80.0 & 6.02 & 34.0 & 89.1 \\
\hline
\end{tabular}

The results of the DCFROR analysis are shown in Figures 4 through 9. Because the eventual price of biomass needed to supply plants such as those studied here is unknown, these figures give the biomass feedstock cost that can be paid to produce hydrogen within the current market values. Conversely, if the biomass cost can be accurately assessed, the necessary hydrogen selling price from this process can be obtained. Figures 4,6 , and 8 show the pre-tax production cost of hydrogen in each of the three schemes at the different plant sizes. Figures 5,7 , and 9 show the necessary hydrogen selling price given a $37 \%$ tax rate and a $15 \%$ after-tax $\mathbb{R R}$. With the market value of hydrogen between $\$ 5 / \mathrm{GJ}$ and $\$ 15 / \mathrm{GJ}$, these figures show that hydrogen can be produced from biomass to compete with current hydrogen production methods on the large and medium scale for all configurations studied. However, the necessary hydrogen selling price is highly dependent upon the biomass feedstock cost, and low-cost biomass will need to be obtained to justify hydrogen from this process, particularly on the small scale. For easy reference, a summary of these results is shown in Table 9. Hydrogen selling prices were calculated using biomass feedstock prices of $\$ 16.50 / \mathrm{T}$ for the small plant and $\$ 46.30 / \mathrm{T}$ for the large plant. Because it is uncertain if nearly $300 \mathrm{~T} /$ day waste biomass at the lower price can be secured, both $\$ 16.50 / \mathrm{T}$ and $\$ 46.30 / \mathrm{T}$ were used to calculate the minimum selling price for the medium size plant. The results shown in this table are representative only of the situations for which biomass can be obtained at the listed prices. The actual biomass price for a given region and situation should be used when assessing the necessary hydrogen selling price from this process. Figures 4 through 9 can be used when assessing specific situations. 


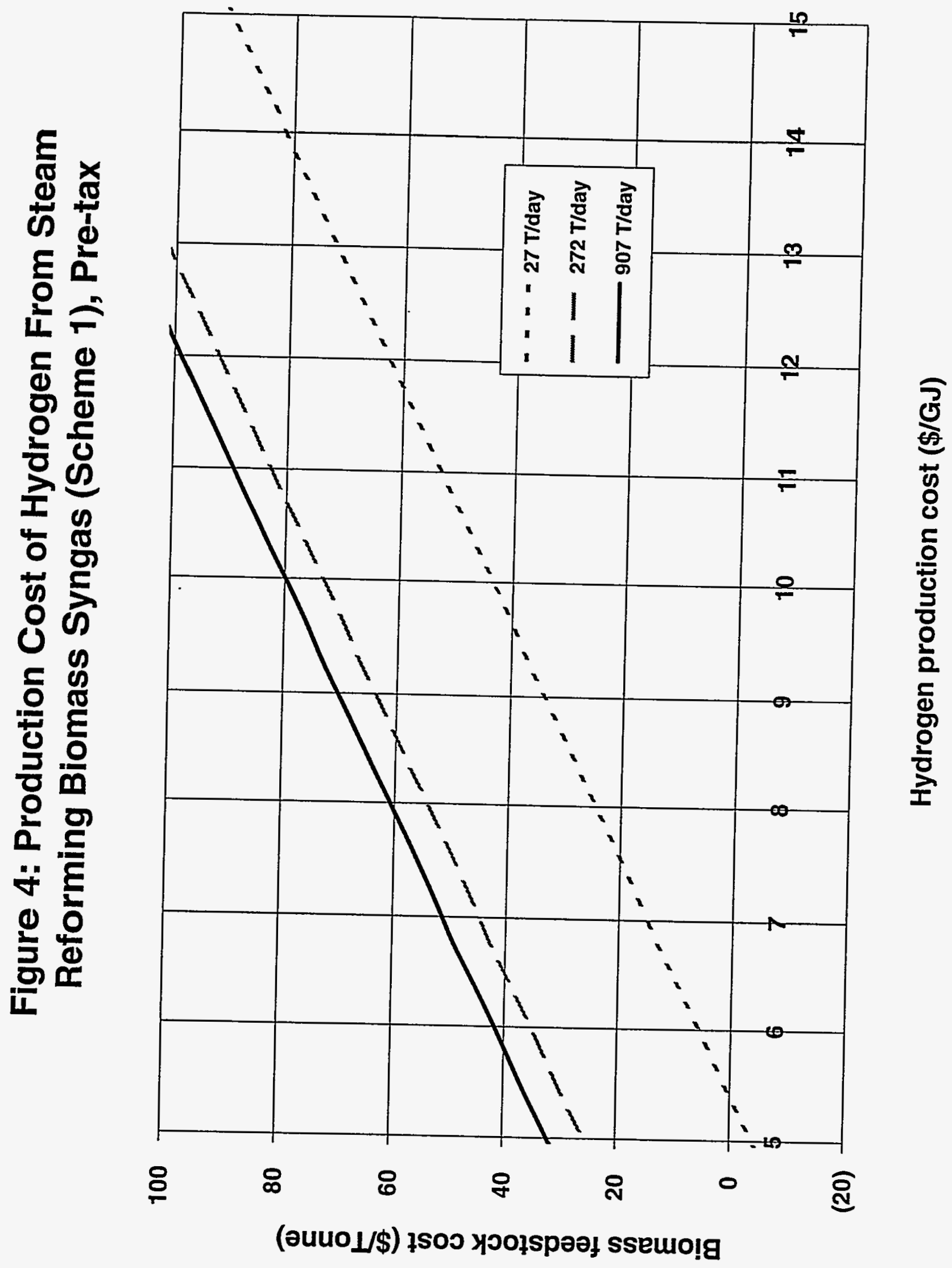


Figure 5: Selling Price of Hydrogen From Steam Reforming Biomass Syngas (Scheme 1), After Tax, 15\% IRR

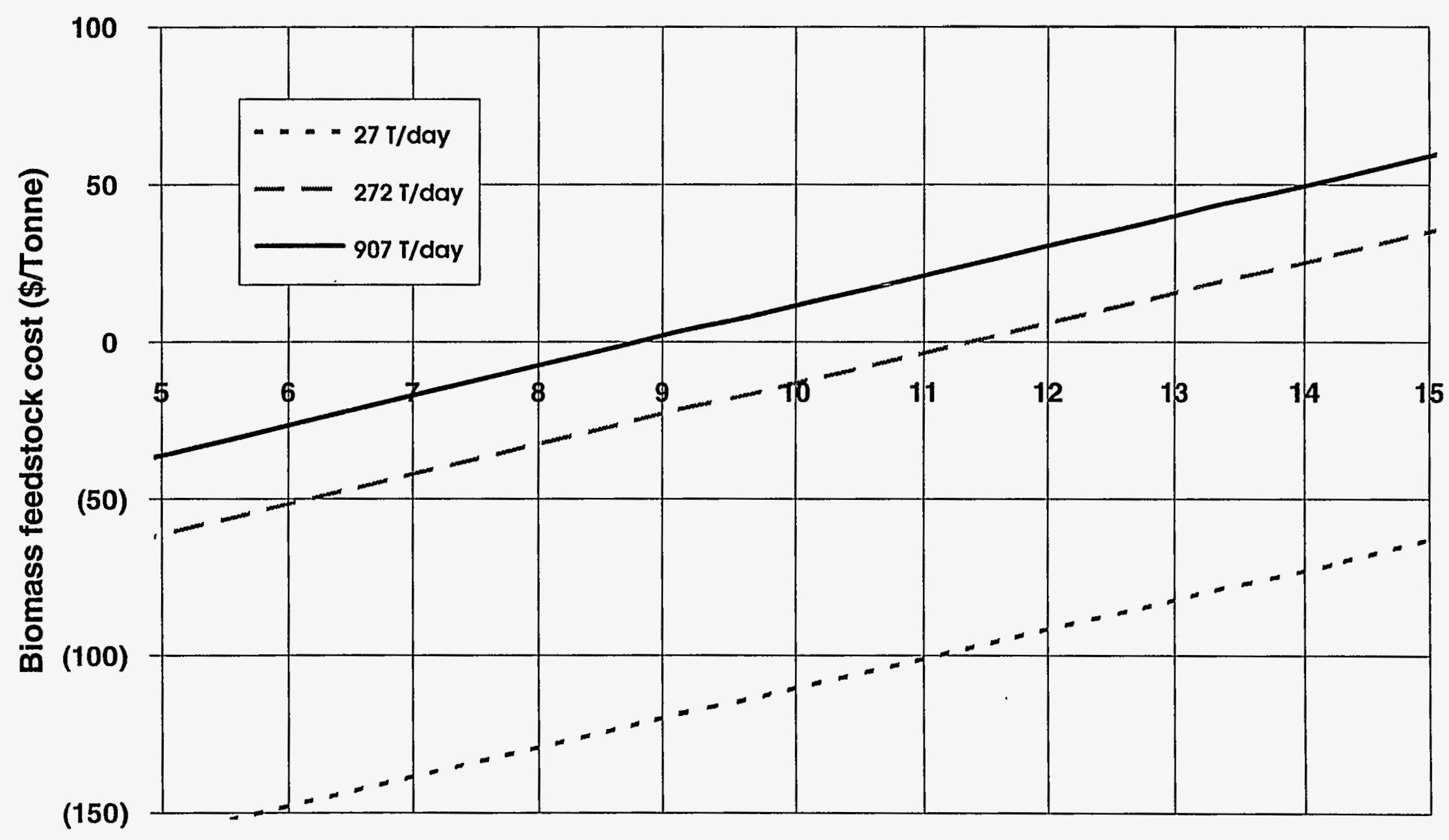

Hydrogen selling price (\$/GJ) 
Figure 6: Production Cost of Hydrogen From Steam Reforming Biomass Syngas (Scheme 2), Pre-tax

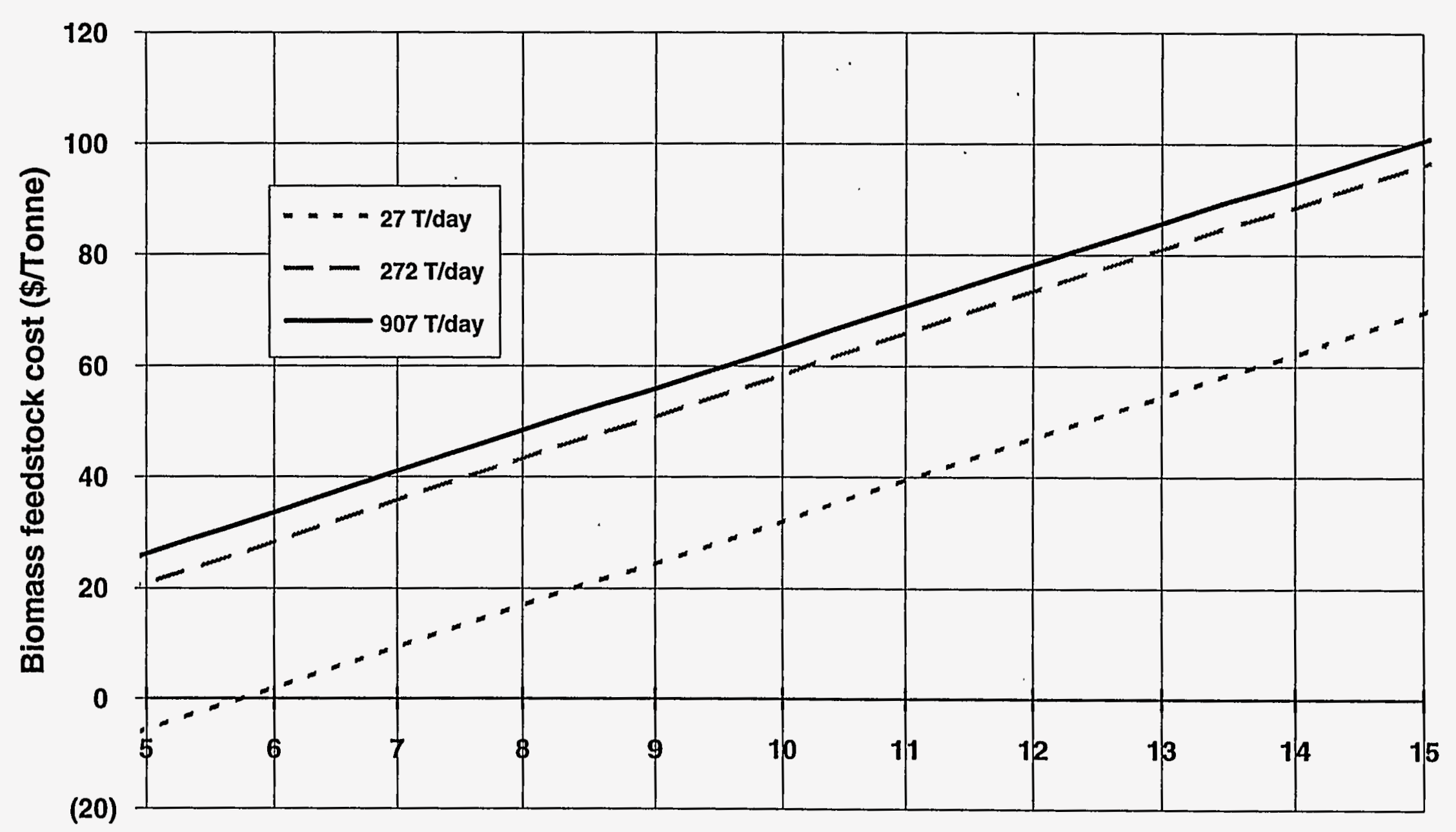

Hydrogen production cost (\$/GJ) 
Figure 7: Selling Price of Hydrogen From Steam Reforming Biomass Syngas (Scheme 2), After Tax, 15\% IRR

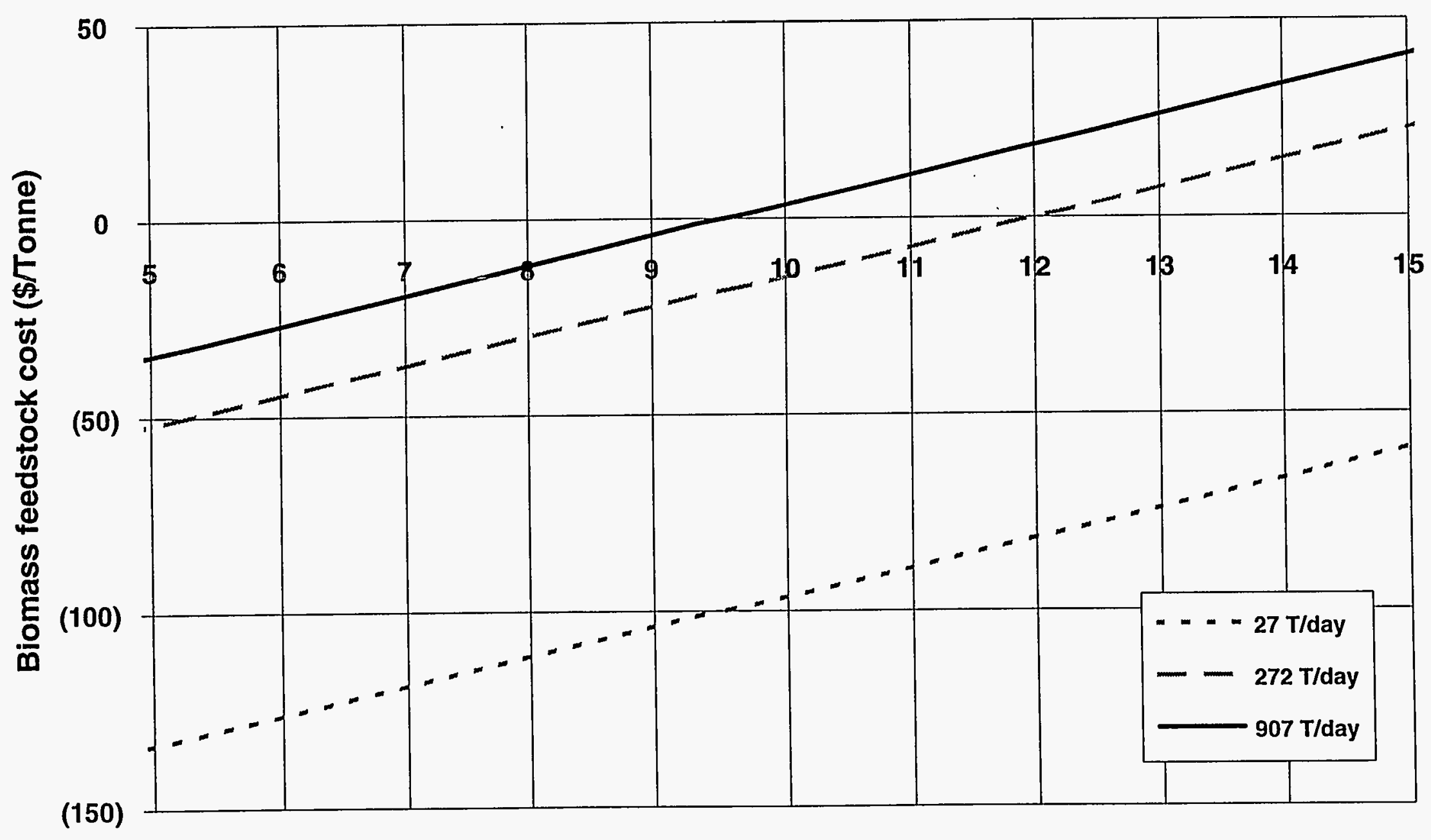

Hydrogen selling price (\$/GJ) 
Figure 8: Production Cost of Hydrogen From Steam

Reforming Biomass Syngas (Scheme 3), Pre-tax

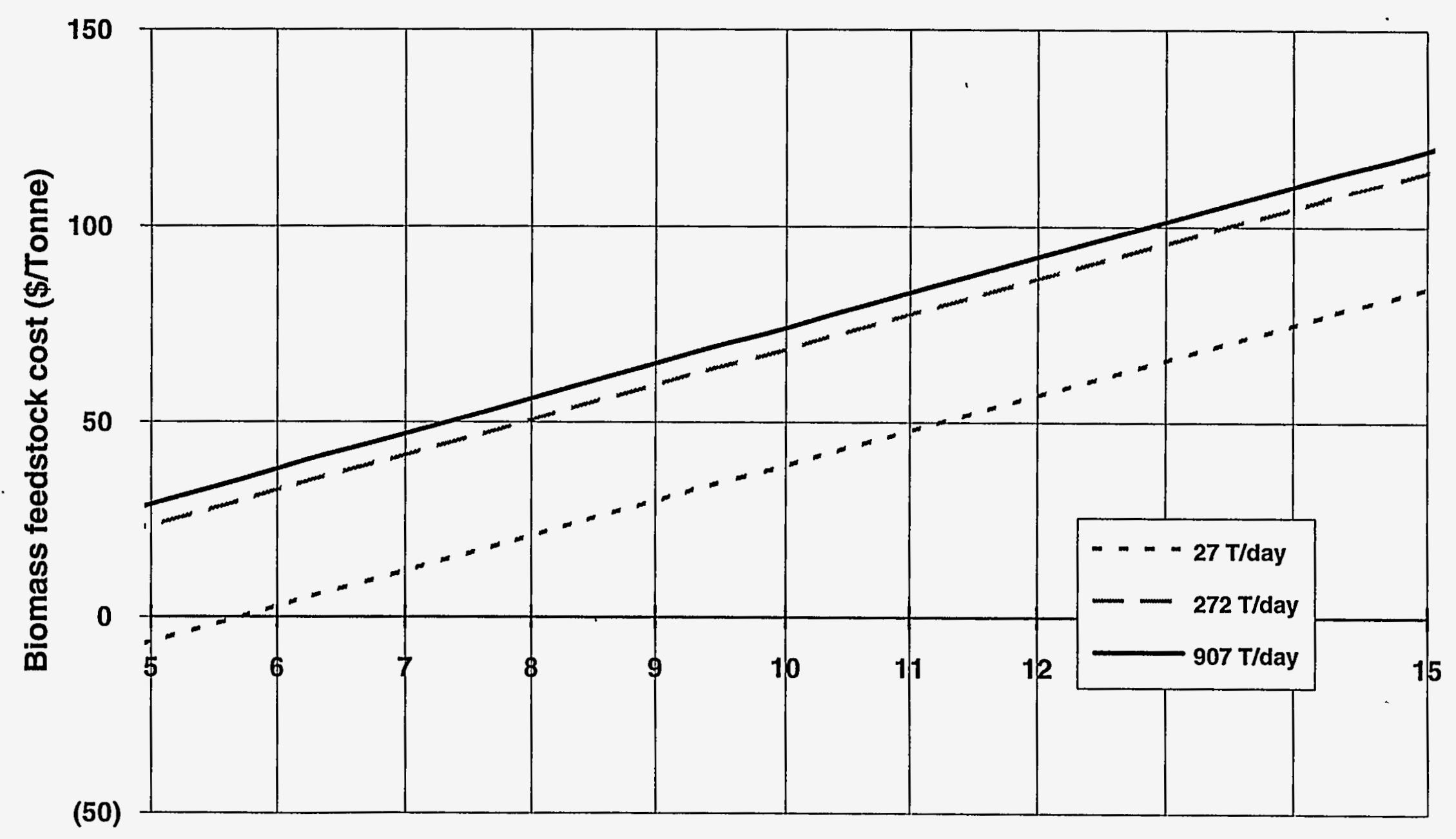

Hydrogen production cost (\$/GJ) 
Figure 9: Selling Price of Hydrogen From Steam Reforming Biomass Syngas (Scheme 3), After Tax, 15\% IRR

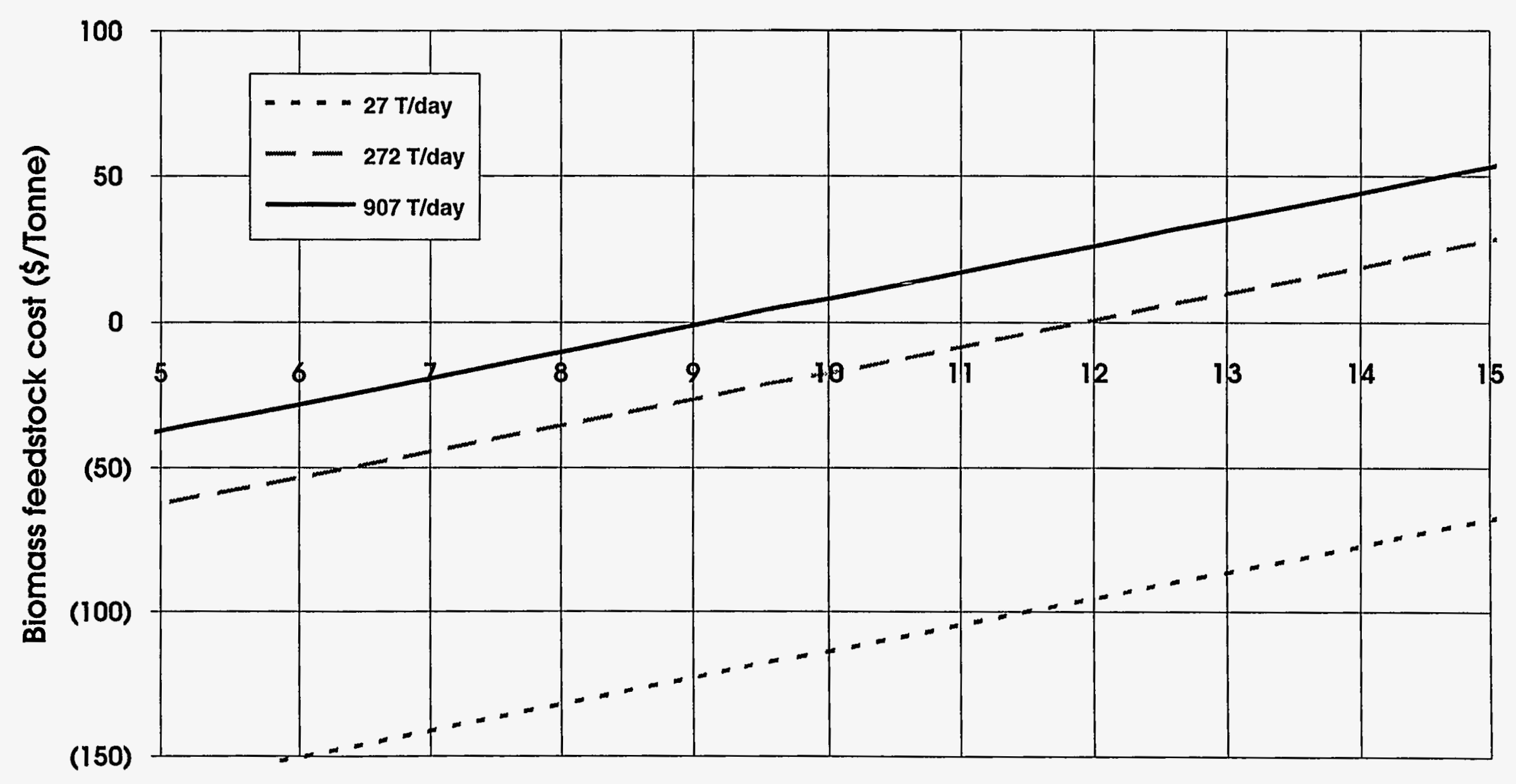

Hydrogen selling price (\$/GJ) 
Table 9: Necessary Hydrogen Selling Price for a 15\% after-tax IRR After Taxes

\begin{tabular}{|l|l|r|r|}
\hline & Plant size & \multicolumn{1}{|l|}{$\begin{array}{l}\text { Biomass cost } \\
(\$ / T)\end{array}$} & $\begin{array}{l}\text { Hydrogen } \\
\text { selling price } \\
(\$ / G J)\end{array}$ \\
\hline \multirow{4}{*}{ Scheme 1 } & small & 16.50 & 23.20 \\
\cline { 2 - 4 } & medium & 16.50 & 13.10 \\
\cline { 2 - 4 } & medium & 46.30 & 16.20 \\
\cline { 2 - 4 } & large & 46.30 & 13.70 \\
\hline Scheme 2 & small & 16.50 & 25.10 \\
\cline { 2 - 4 } & medium & 16.50 & 14.20 \\
\cline { 2 - 4 } & medium & 46.30 & 18.20 \\
\cline { 2 - 4 } & large & 46.30 & 15.70 \\
\hline \multirow{5}{*}{ Scheme 3 } & small & 16.50 & 24.30 \\
\cline { 2 - 4 } & medium & 16.50 & 13.70 \\
\cline { 2 - 4 } & medium & 46.30 & 17.00 \\
\cline { 2 - 4 } & large & 46.30 & 14.20 \\
\hline
\end{tabular}

From Figures 4 through 9, it can be seen that the cost of producing less hydrogen in Schemes 2 and 3 is higher than the savings obtained by eliminating some unit operations in the reforming section of the process. Of the three process configurations studied, the most profitable is Scheme 1. Of the two configurations with reduced reforming operations, Scheme 3, with the primary reformer and high temperature shift reactor, is more economic than Scheme 2 with only the primary reformer. This is because the majority of the water gas shift reaction takes place in the high temperature shift reactor. Scheme 3 is not as economic as Scheme 1 even though capital costs are lower because of the absence of the low temperature shift reactor, the decreased amount of hydrogen that is produced reduces the net income over the life of the plant.

The most economic size for the process studied depends upon the feedstock cost. If the medium size plant can be supplied with waste biomass at a cheaper price (i.e., $\$ 16.50 / \mathrm{T}$ ) than the biomass supplied by a DFSS, the necessary hydrogen selling price from the medium size plant is lower than that from the large plant. However, if the medium and large plants must both use biomass from a DFSS, the larger plant is more economically feasible. The medium size plant is more economic than the small plant if biomass at the same feedstock cost is used in each. Figures 4 through 9 also show that there is a larger economy of scale realized in going from the small to the medium size plant than in going from the medium to the large plant. Figure 5 shows that for positive biomass feedstock costs, the necessary hydrogen selling price would have to be at least $\$ 8.70 / \mathrm{GJ}$ and $\$ 11.20 / \mathrm{GJ}$ for the large and medium size plants, respectively. Unless biomass at extremely low costs can be obtained, hydrogen produced in the small indirectly heated gasification and reforming operation is not economically feasible. Figures 7 and 9 give similar results. 
Figures 10 through 12 show the cumulative cash flow for the three plant sizes for Scheme 1 over a twenty-year plant life. The corresponding curves for Schemes 2 and 3 are similar. Figures 10 and 11 show the cash flow for the 27 and $272 \mathrm{~T} /$ day plant using a biomass feedstock cost of $\$ 16.50 / \mathrm{T}$. Figure 12 is the cash flow diagram. for the $907 \mathrm{~T} /$ day plant using a feedstock cost of $\$ 46.30 / \mathrm{T}$. Each diagram is based on a hydrogen selling price of $\$ 11 / G J(\$ 12 / M M B t u)$. The break-even point for the medium plant (6.3 years) is sooner than that for the large plant ( 7.2 years) because of the lower feedstock cost. If the medium plant were also using biomass at $\$ 46.30 / T$, the break-even point would be 9.5 years.

Table 10 gives the discount rate used to set the net present value to zero for each scheme at the three plant sizes. This rate was calculated using a hydrogen selling price of $\$ 11 /$ GJ $(\$ 12 / \mathrm{MMBtu})$. The biomass costs used were $\$ 16.50 / \mathrm{T}$ for the small plant and $\$ 46.30 / \mathrm{T}$ for the large plant; the discount rate for the medium plant was calculated using both biomass costs. The rates obtained in this analysis are low in comparison to other processes which reach commercialization. A better estimate for how much the biomass feed will cost will reduce some of the uncertainty in these calculations, and it may be that the discount rates are higher than reported here.

Table 10: Discount Rate Obtained from Return on Investment Analysis

\begin{tabular}{|l|l|r|r|}
\hline \multirow{4}{*}{ Scheme 1 } & Plant size & \multicolumn{1}{|l|}{$\begin{array}{l}\text { Biomass cost } \\
(\$ / \mathrm{T})\end{array}$} & $\begin{array}{l}\text { Discount rate } \\
\text { for NPV=0 } \\
(\%)\end{array}$ \\
\cline { 2 - 4 } & small & 16.50 & 4.0 \\
\cline { 2 - 4 } & medium & 16.50 & 10.4 \\
\cline { 2 - 4 } & medium & 46.30 & 6.7 \\
\cline { 2 - 4 } & large & 46.30 & 9.2 \\
\hline \multirow{5}{*}{ Scheme 2 } & small & 16.50 & 3.0 \\
\cline { 2 - 4 } & medium & 16.50 & 9.4 \\
\cline { 2 - 4 } & medium & 46.30 & 4.7 \\
\cline { 2 - 4 } & large & 46.30 & 6.6 \\
\hline \multirow{5}{*}{ Scheme 3 } & small & 16.50 & 3.5 \\
\cline { 2 - 4 } & medium & 16.50 & 9.9 \\
\cline { 2 - 4 } & medium & 46.30 & 6.0 \\
\cline { 2 - 4 } & large & 46.30 & 8.4 \\
\hline
\end{tabular}


Figure 10: Cumulative Cash Flow for a $27 \mathrm{~T} /$ day Biomass Gasification and Reforming Facility

Feedstock cost $=\$ 16.50 / \mathrm{T}$

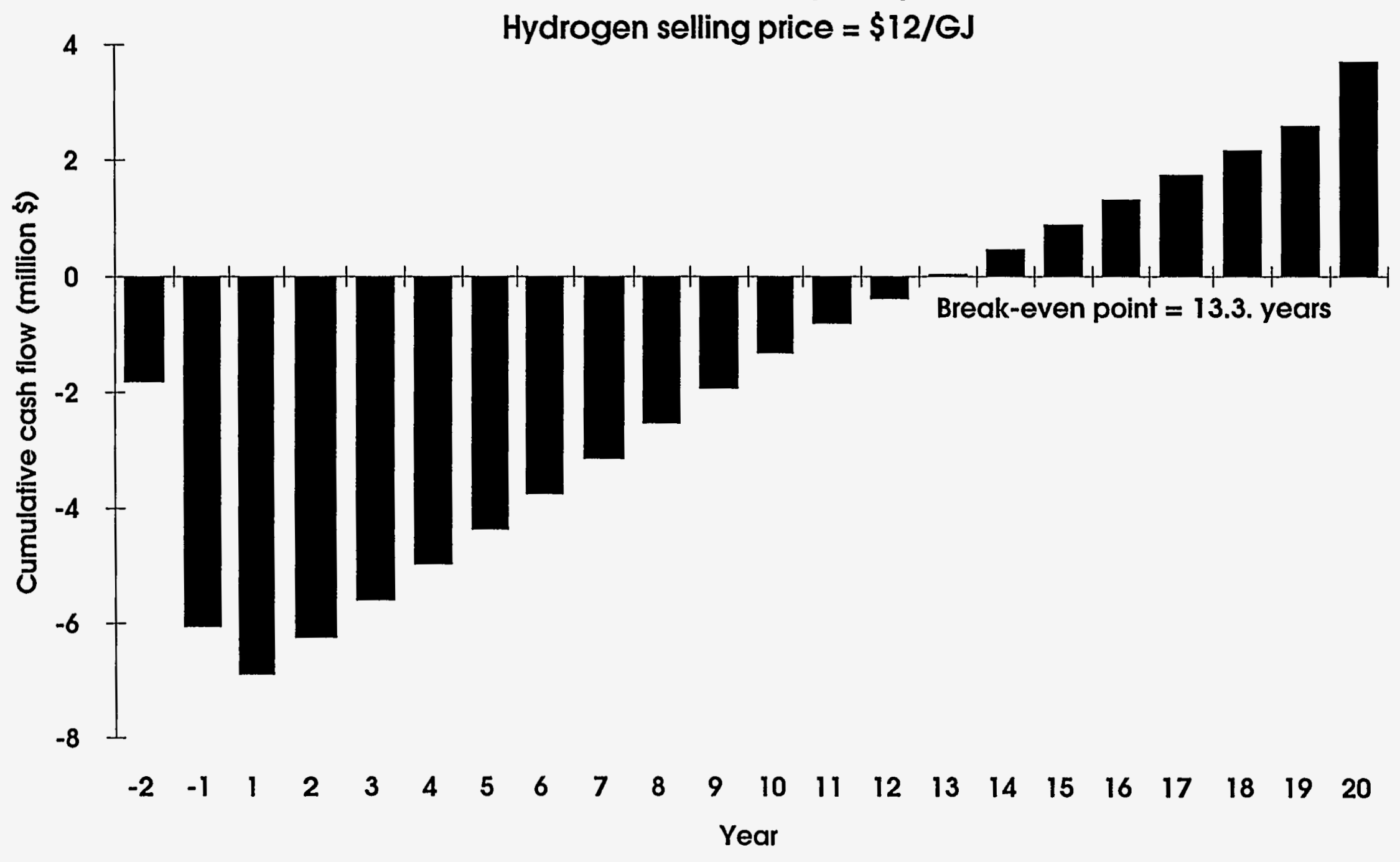


Figure 11: Cumulative Cash Flow for a 272 T/day Biomass Gasification and Reforming Facility

Feedstock cost $=\$ 16.50 / \mathrm{T}$

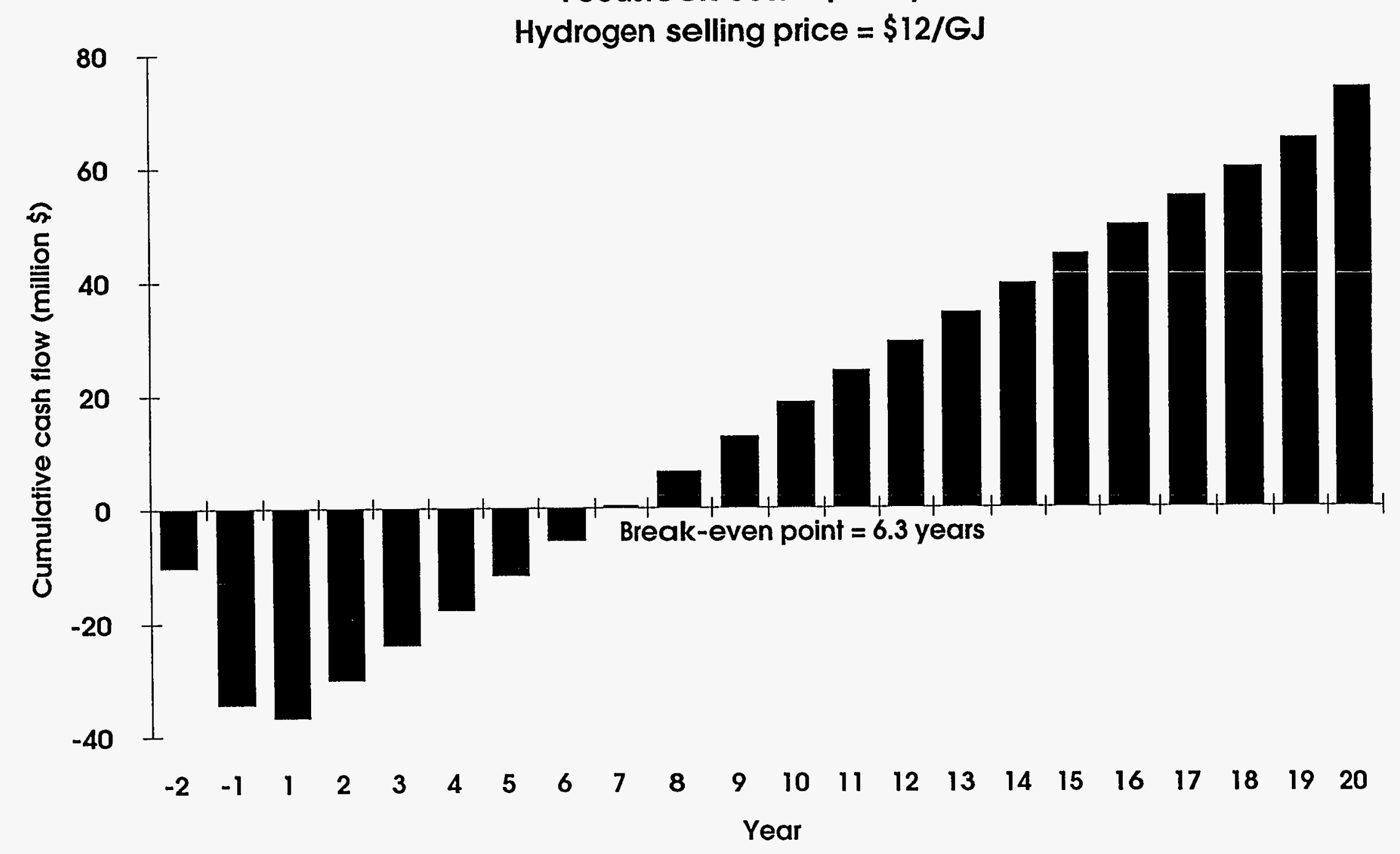


Figure 12: Cumulative Cash Flow for a 907 T/day Biomass Gasification and Reforming Facility

Feedstock cost $=\$ 46 / \mathrm{T}$

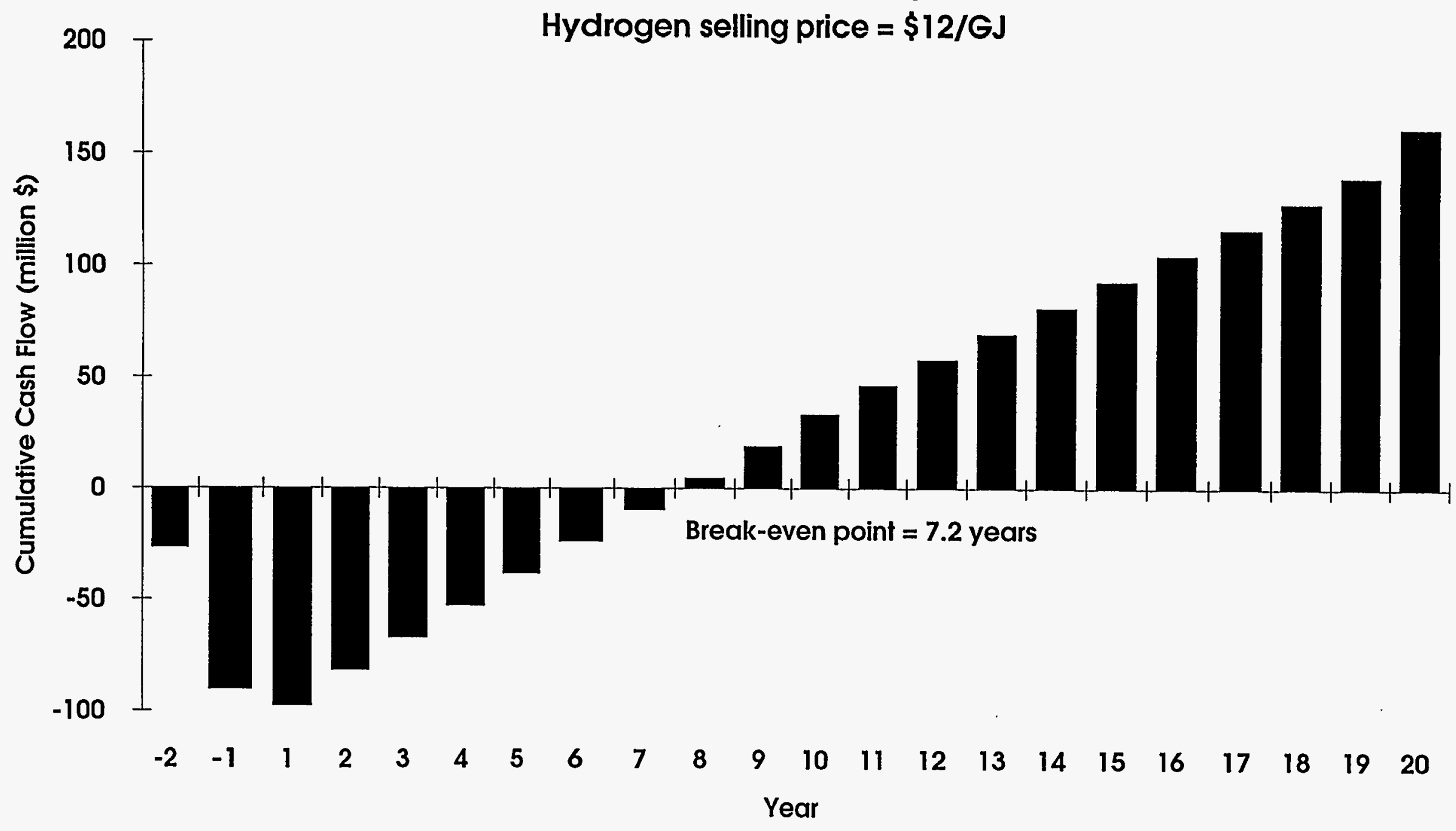




\subsection{Conclusions}

Compared to conventional hydrogen producing processes, many of the criteria for successful commercialization of this process are not met. This is because the gasification technology is not fully optimized and tested, and that the reforming process was developed specifically for natural gas and not biomass syngas. Additionally, a higher and more conservative IRR was used for the DCFROR analysis. The necessary selling price of hydrogen from this process falls at the higher end of the current market value range. Also, the discount rates obtained in the ROI analysis are low and the break-even times are fairly long. Therefore, improvements in process design and conversion yields will be necessary for this process to be readily commercialized.

The necessary selling price of hydrogen produced by steam reforming syngas from the BCL gasifier falls within current market values for many of the scenarios studied. The factors that determine which scenario is the most economically feasible are design configuration, plant size, and biomass feedstock costs. The configuration that produces the least expensive hydrogen is that which uses all reforming operations, Scheme 1. Therefore, for the reforming process studied, as much hydrogen as possible should be made at the expense of higher capital equipment charges. Of the three plant sizes studied, the most economic configuration depends upon the availability of waste biomass at a lower price than biomass from a DFSS. If waste biomass can be obtained for the medium size plant, this scale is the most economic. However, if DFSS biomass must be used for both the medium and large plants, the $907 \mathrm{~T} /$ day plant produces hydrogen at a cheaper price than the $272 \mathrm{~T} /$ day plant. Results show that unless biomass can be obtained at very low prices, producing hydrogen from a very small plant acting as a local refueling station will not be economically competitive.

As the development of biomass-based technologies continues and better predictions for the costs of biomass from energy crop improvements can be made, the examples of costs given in this study can be revisited using the curves of hydrogen price versus feedstock cost. For this process to be economically viable in the marketplace, low biomass costs will probably be necessary. As research continues on processes that use biomass and as uncertainties are addressed, the risk of investing in such projects will decrease. This will reduce the necessary hydrogen selling price and provide a shorter break-even point.

\subsection{Future Work}

Additional benefits of producing hydrogen on the small scale via reforming syngas from the BCL gasifier should be studied and incorporated into the estimated cost. For example, if hydrogen is produced at the point of its intended use, compression, storage, and transportation costs will be lower than on the larger production scale, or eliminated completely. On the medium and large scales, this cost mitigation is less likely, thus making on-site hydrogen production more attractive than shown in this report.

The ASPEN Plus ${ }^{\mathrm{TM}}$ model of the reforming operation will be optimized to increase hydrogen production efficiency and reduce costs. Areas targeted for improvement will be determined from sensitivity analyses within ASPEN Plus ${ }^{\mathrm{TM}}$ and the economic spreadsheet model. One option that might help costs is the addition of a steam turbine to produce electricity from the excess heat in the reforming operation. Also, a quench operation will be tested to cool the feed to the PSA unit. Furthermore, new information obtained in the testing and scale-up of the $\mathrm{BCL}$ gasifier will be incorporated into this analysis to measure cost improvement. 
As biomass-based processes become better developed and the uncertainties associated with the cost of the biomass feedstock decrease, the assumptions made in this analysis will be revisited. Currently, the biomass feedstock cost is a result of the analysis, determined from the cost curves set between the current high and low. market values of hydrogen.

A life cycle assessment will be conducted on these processes to determine their environmental impacts in terms of energy consumption and emissions to water and the air. This will include a comparative analysis of conventional hydrogen producing processes.

The economic and environmental effects of reforming a mixture of biomass syngas and natural gas should be studied. Because the stoichiometric maximum amount of hydrogen that can be produced from methane is higher than from syngas, the overall amount produced would be higher. This scenario would allow for higher hydrogen recovery by avoiding the need for the recycle stream used to increase the percentage of hydrogen in the PSA feed, while maintaining or sacrificing only a small portion of the benefits obtained in using a biomass-based process. This may also be a means of transition from the current hydrogen production technologies to a renewable technology. 


\section{References and Pertinent Literature}

Anand, M. (April, 1995). Personal Correspondence.

Bain, R. (January 14, 1992). Material and Energy Balances for Methanol from Biomass Using Biomass Gasifiers. Golden, Colorado: National Renewable Energy Laboratory.

Bland, W.; Davidson, R.L., eds. (1967). Petroleum Processing Handbook. New York: McGraw-Hill; pp. 140-148.

Branan, C., ed. (1994). Rules of Thumb for Chemical Engineers. Houston, Texas: Gulf Publishing Company.

Breault, R.; Morgan, D.; (1992). Design and Economics of Electricity Production from and Indirectly Heated Biomass Gasifier. Report TR4533-049-92. Columbus, Ohio: Battelle Columbus Laboratory.

Chomet, E.; Czemik, S.; Wang, D.; Mann, M. (1994). Biomass to Hydrogen via Fast Pyrolysis and Reforming. Department of Energy Hydrogen Program Review.

Chum, H.L.; Black, S.K Process for Fractionating Fast Pyrolysis Oils and Products Derived Therefrom. U.S. Patent No. 4,942,269 (17 July 1990).

Double, J.M.; (1988) Design, Evaluation and Costing of Biomass Gasifiers. Doctoral Thesis.

Dravo Engineering Companies. (1987). Gasification Capital Cost Estimation. Obtained from Mark Paisley in personal correspondance, August, 1994. Battelle Columbus Laboratory.

Feldmann, H.; Paisley, M.A. (May 1988). Conversion of Forest Residues to a Methane-Rich Gas in a HighThroughput Gasifier. Columbus, Ohio: Battelle Columbus Laboratory.

Garrett, D. (1989). Chemical Engineering Economics. New York: Reinhold.

Gerhartz, W., ed. (1989). Ullman's Encyclopedia of Industrial Chemistry. Germany: VCH; Vols. A13, A17, A22.

Gregoire, C.E. (1992). Technoeconomic Analysis of the Production of Biocrude from Wood. Golden, CO. NREL Report TP-430-5435.

Kirk, R.; Othmer, D., eds. (1983). Encyclopedia of Chemical Technology. New York: Wiley \& Sons; Vols. $12,15,19$.

Larson, E.; Katofsky, R. (July 1992). Production of Methanol and Hydrogen from Biomass. PULCEES Report No. 271. Princeton University: Center for Energy and Environmental Studies.

Moe, J. (March 1962). "Design of Water-Gas Shift Reactors." Chemical Engineering Progress; Vol. 58, [3], pp. 33-36.

Ogden, J.; Dennis, E.; Steinbugler, M.; Strohbehn, J.W. (January 18, 1995). Hydrogen Energy Systems Studies. Princeton University: Center for Energy and Environmental Studies, Figure 5b. 
Ogden, J.; Larson, E.; Delucchi, M. (May 27, 1994). A Technical and Economic Assessment of Renewable Transportation Fuels and Technologies. Princeton University: Center for Energy and Environmental Studies.

Peters, M.; Timmerhaus, K. (1980). Plant Design and Economics for Chemical Engineers. 3rd edition. New York: McGraw-Hill.

Peters, M.; Timmerhaus, K. (1991). Plant Design and Economics for Chemical Engineers. 4th edition. New York: McGraw-Hill.

Pikulik, A.; Diaz, H. (October 10, 1977). "Cost Estimating for Major Process Equipment." Chemical Engineering; Vol. 84, [21], pp. 106-122.

Schendel, R.L.; Mariz, C.L.; Mak, J.Y. (August 1983). Hydrocarbon Processing; Vol. 62, p. 58.

SRI International. (1994). Chemical Economics Handbook. Menlo Park, California.

Stultz, S.C.; Kitto, J.B. (1992). Steam. Barberton, Ohio: Babcock and Wilcox.

Sunggyu, L. (1990). Methanol Synthesis Technology. Boca Raton, Florida: CRC Press; pp. 4-22.

Supp, E. (1990). How to Produce MeOH from Coal. Germany: Springer-Verlag; pp. 44-93, 183-185.

Tindall, B.M.; King, D.L. (July 1991). "Designing Steam Reformers for Hydrogen Production." Hydrocarbon Processing; Vol. 73, [7], pp. 69-75.

Twigg, M., ed. (1989). Catalyst Handbook. Cleveland, Ohio: Wolfe Publishing; p. 87-89, 262.

Weenen, W.; Tielrooy, J. (February 1983). "Optimizing Hydrogen Plant Design." Chemical Engineering Progress; Vol. 79, [2], pp. 37-44.

Weyerhaeuser. (1992). Gasification Capital Cost Estimation. Obtained from Mark Paisley in personal correspondance, August, 1994. Battelle Columbus Laboratory.

Woods, D.R. (1975). Financial Decision Making in the Process Industry. New Jersey: Prentice Hall. 
Appendix A: $\quad$ ASPEN Plus Input File Gasifier Fortran Subroutine 
DEF-STREAMS MIXCINC ALL

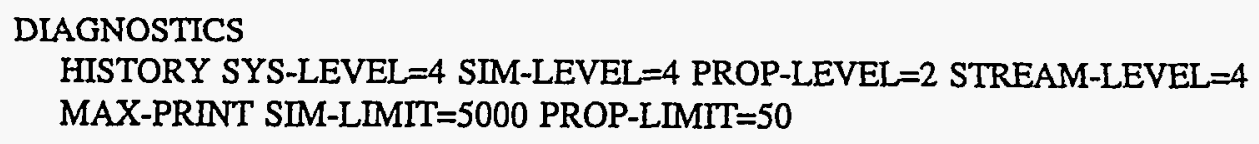




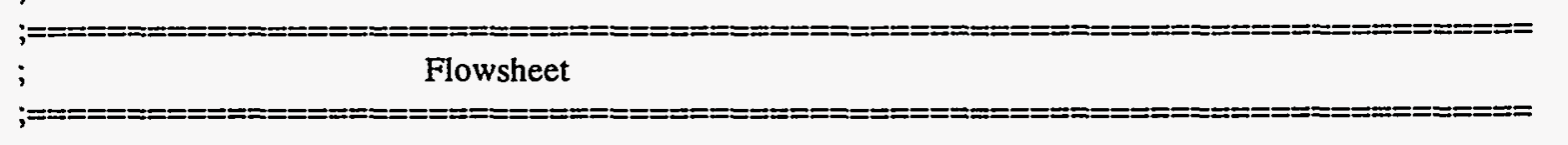

FLOWSHEET MAIN

BLOCK FEEDMIX IN=GASIFSTM WOOD SAND OUT=GFEED

BLOCK GASIFIER IN=GFEED OUT=WOODGAS QGAS

BLOCK CHARSEP IN=WOODGAS OUT=CHAR SYNGAS

BLOCK CHARDEC IN=CHAR OUT=CHARCOMP QCHAR

BLOCK AIRHEAT IN=COMBAIR2 OUT=HCOMBAIR QAIR

BLOCK CHARFURN IN=CHARCOMP HCOMBAIR SANDSUPP $Q C H A R$ OUT $=\&$ COMBPROD QCOMB

BLOCK COMBSPLT IN=COMBPROD OUT=CHARFLUE ASHSAND

BLOCK SANDSPLT $\mathbb{I N}=$ ASHSAND OUT=SAND SANDPURG

BLOCK SYNCOMPR IN=TOCOMPR OUT=SYNCOMPD 205

BLOCK PRIMARY IN=TOREFHOT REFSTM OUT=SYNREFRM 105

BLOCK HTSHIFT IN=TOHT OUT=FROMHT QHT

BLOCK LTSHIFT IN=TOLT OUT=FROMLT QLT

BLOCK REFHTR IN=207 OUT=TOREFHOT 198

BLOCK WATPUMP IN=REFSTMA OUT=REFSTMB

BLOCK WOODSEP IN=ARWOOD OUT=WOODWAT MIDWOOD

BLOCK DRY2 IN=MIDWOOD WETDAIR OUT=DRYWOOD

BLOCK DRY1 IN=WOODWAT FLUENAIR OUT=WETDAIR

BLOCK DRYRMIX IN=CHARFLUE DRYRAIR2 OUT=FLUENAIR

BLOCK PSA IN=TOPSAB OUT=H2PURIFY OFFGAS

BLOCK OFFCOMB IN=OFFGAS OFFAIR2 105 OUT=OFFFLUE1

BLOCK GSTMGEN IN=SYNREFRM GSTMIN OUT=FROMPRIM GASIFSTM

BLOCK AIRCOMP1 IN=COMBAIR OUT=COMBAIR2

BLOCK AIRCOMP2 IN=DRYRAIR OUT=DRYRAIR2

BLOCK DRYRSEP IN=DRYWOOD OUT=DRIED GASWAT

BLOCK MODELI IN=HOTIN COLDIN OUT=HOTOUT COLDOUT

BLOCK SYNCOOL1 IN=SYNGAS OUT=SYNCOLD 197

BLOCK MODEL2 IN=HI CI OUT=HO CO

BLOCK LTCOOL IN=FROMHT 196 OUT=TOLT STEAM6

BLOCK OFFCOMPR IN=OFFAIR1 OUT=OFFAIR2

BLOCK REFSTM IN=REFSTMB OUT=REFSTM 135

BLOCK COMBCOOL IN=OFFFLUE1 135 OUT=OFFFLUE2

BLOCK HTCOOL IN=FROMPRIM OUT=TOHT

BLOCK PUMP1 IN=BFW1A OUT $=145$

BLOCK INTER2A IN=GAS2A 160 OUT=COOLED2A STEAM2A

BLOCK INTER2B IN=GAS2B 165 OUT=COOLED2B STEAM2B

BLOCK PUMP4 IN $=B F W 2 A$ OUT $=160$

BLOCK PUMP5 IN=BFW2B OUT $=165$

BLOCK RECMLX IN=TOPSAA H2RECYCL OUT $=$ TOPSAB

BLOCK RECSPLT IN=H2PURIFY OUT=H2PROD H2RECYCL

BLOCK STMGEN6 IN=OFFFLUE2 188 OUT=OFFFLUE3 STEAM4

BLOCK B13 IN=BFW4 OUT $=188$

BLOCK B3 IN=BFW6 OUT $=196$

BLOCK B1 IN=SYNCOLD OUT=KOWATER TOCOMPR

BLOCK B2 IN=SYNCOMPD 208205 OUT $=207$

BLOCK B5 IN=KOWATER OUT $=208$

BLOCK PSACOOL IN=FROMLT 212 OUT=TOPSAA STEAM5 189 
BLOCK B7 IN=BFW5 OUT $=212$

BLOCK B4 IN=GAS1A OUT=COOLED1A 213

BLOCK B6 IN=145 213 OUT=STMWAT

BLOCK STMFLASH IN=STMWAT OUT=STEAM1A WAT1A

;

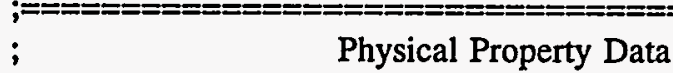

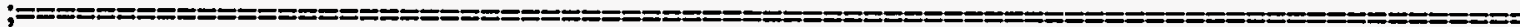

;

PROPERTIES SYSOP3

PROP-REPLACE SYSOP3 RKS-BM

PROP MUVMX MUVMX02

PROP MULMX MULMX02

PROP KVMX KVMX02

PROP KLMX KLMX01

PROP DV DV01

PROP MUL MUL01

PROP MUV MUV01

PROP KV KV01

PROP KL KL01

;

NC-COMPS WOOD ULTANAL SULFANAL PROXANAL

NC-PROPS WOOD ENTHALPY HCJ1BOIE / DENSITY DCOALIGT

NC-COMPS ASH GENANAL ULTANAL SULFANAL PROXANAL

NC-PROPS ASH ENTHALPY HCJ1BOIE / DENSITY DNSTYGEN

NC-COMPS CHAR ULTANAL SULFANAL PROXANAL

NC-PROPS CHAR ENTHALPY HCJ1BOIE / DENSITY DCHARIGT

PROP-DATA DATA1

IN-UNITS ENG

PROP-LIST DGSFRM / DHSFRM / MW

PVAL O2SI $.0 / .0 / 60.0860$

PVAL CARBON .0/.0/12.0110

PVAL SULFUR .0 / .0 / 32.0640

;

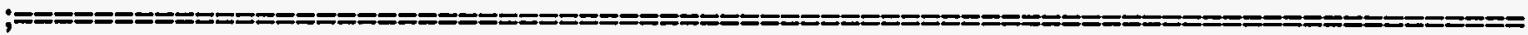

; Conventional Component Property Data

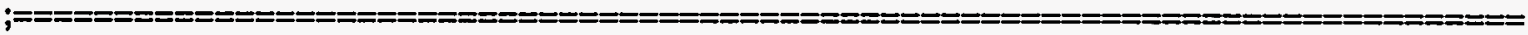

;

PROP-DATA DATA5

IN-UNITS SI TEMPERATURE=F

PROP-LIST VSPOLY 
PVAL CARBON .005340.0.0.0.0 0 .0 2500.0

PVAL SULFUR .01550 .0.0 0.0 .0 2500.0

PROP-DATA U-1

IN-UNITS ENG MOLE-HEAT-CA='CAL/MOL-K' TEMPERATURE=K

PROP-LIST CPSPO1

PVAL CARBON 2.6730.0026170.0 0 .0 -116900.0 .0 273.0 \& 1373.0

PVAL O2SI 12.80.004470.0 0 -302000.0.0 273.0 1973.0

PVAL SULFUR $3.630 .00640 \quad 0.0 \quad 0.00 .00 .00 .01000 .000$

PROP-DATA U-2

IN-UNITS SI

PROP-LIST DENGEN

PVAL ASH 2000.0 .0 .0

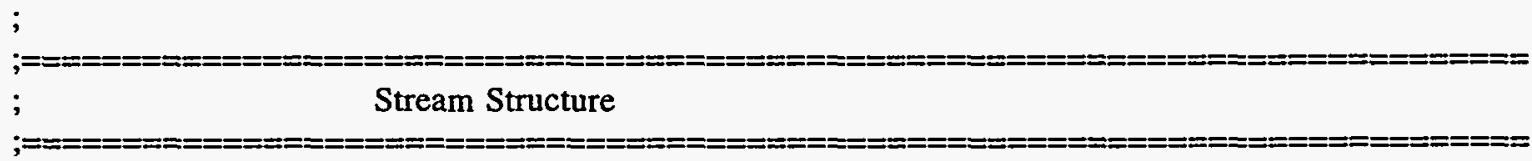

PROP-SET PS-1 CP RHO UNITS=BTU/LB-R' 'GM/CC' LB/CUFT' \& SUBSTREAM=MIXED COMPS=O2SI CARBON SULFUR PHASE $=S$

PROP-SET PS-2 DENSITY HEAT-CAP UNITS=LB/CUFT' 'GM/CC' \& 'BTU/LB-R' 'CAL/GM-K' SUBSTREAM=NC COMPS=WOOD ASH CHAR \& PHASE $=S$

STREAM 207

STREAM ARWOOD

SUBSTREAM MIXED TEMP=59 PRES $=14.696$

MASS-FLOW H2O .78

SUBSTREAM NC TEMP $=59$ PRES $=14.696$

MASS-FLOW WOOD 1

COMP-ATTR WOOD ULTANAL ( $.92050 .8806 .04 .1700 .09 \&$ 41.9)

COMP-ATTR WOOD SULFANAL $(.450 .02250 .02250)$

COMP-ATTR WOOD PROXANAL ( $\begin{array}{lll}11 & 15.29 & 83.52 \\ \text {.8. }\end{array}$

\author{
STREAM BFW1A \\ SUBSTREAM MIXED TEMP=170 PRES $=30$ \\ MASS-FLOW H2O .8 \\ STREAM BFW2A \\ SUBSTREAM MIXED TEMP=59 PRES $=30$ \\ MASS-FLOW H2O 0565 \\ STREAM BFW2B \\ SUBSTREAM MIXED TEMP=59 PRES=30 \\ MASS-FLOW H2O .04825 \\ STREAM BFW4
}


SUBSTREAM MIXED TEMP $=59$ PRES $=30$

MASS-FLOW H2O .378

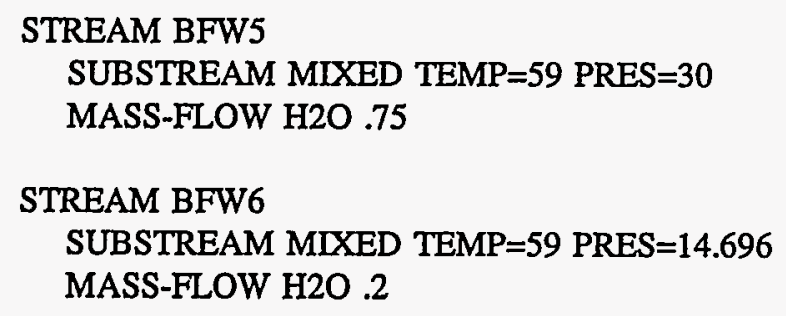




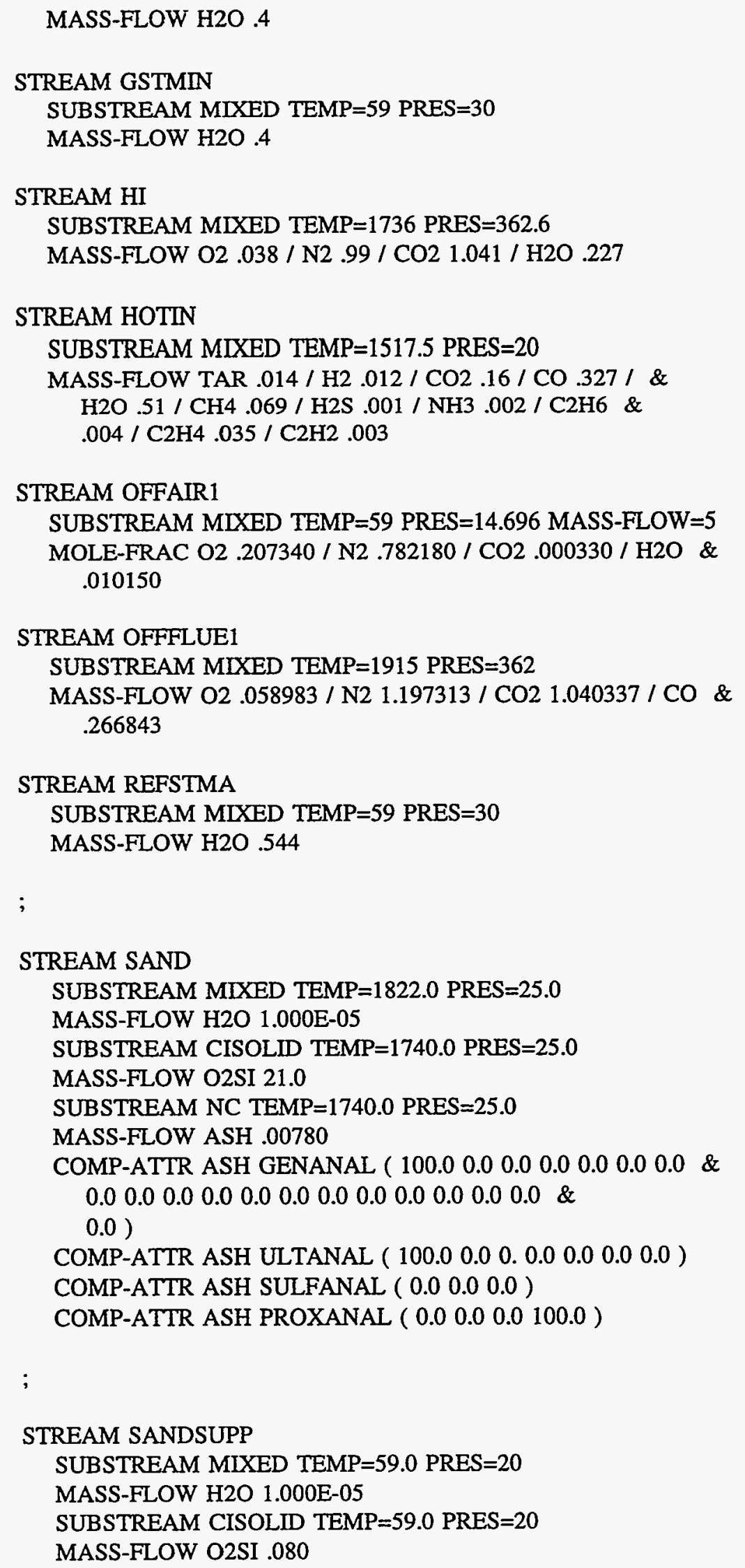




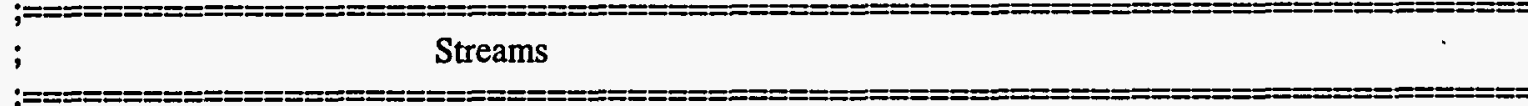

;

CoalMisc (8476.0 $0.0 \quad 0.00 .00 .0)$

STREAM WOOD

SUBSTREAM MIXED TEMP=155 PRES=25

SUBSTREAM CISOLID TEMP $=220$ PRES $=25$

MASS-FLOW CARBON 1.000E-05

SUBSTREAM NC TEMP=220 PRES=25

MASS-FLOW WOOD 1.0 / ASH 1.000E-05 / CHAR 1.000E-05

COMP-ATTR WOOD ULTANAL ( $92050.8806 .040 .170 .0 .090 \&$ 41.90 )

COMP-ATTR WOOD SULFANAL ( 450.02250 .02250$)$

COMP-ATTR WOOD PROXANAL ( 11.015 .29083 .520 .870 )

COMP-ATTR ASH GENANAL ( $100.0 .0 .0 .0 .0 .0 .0 .0 \&$

$.0 .0 .0 .0 .0 .0 .0 .0 .0 .0 .0 .0)$

COMP-ATTR ASH ULTANAL ( 100.0 .0 .0 .0 .0 .0 .0$)$

COMP-ATTR ASH SULFANAL ( 0.0 .0$)$

COMP-ATTR ASH PROXANAL ( .0 .0 .0100 .0$)$

COMP-ATTR CHAR ULTANAL ( .086 .0 4.0 .0.0 .030 9.970 \& )

COMP-ATTR CHAR SULFANAL ( .010 .010 .010$)$

COMP-ATTR CHAR PROXANAL ( .087 .18012 .810 .010$)$

DEF-STREAMS HEAT 105

DEF-STREAMS HEAT 135

DEF-STREAMS HEAT 197

DEF-STREAMS HEAT 198

DEF-STREAMS HEAT 213

DEF-STREAMS HEAT QAIR

DEF-STREAMS HEAT QCHAR

DEF-STREAMS HEAT QCOMB

DEF-STREAMS HEAT QGAS

DEF-STREAMS HEAT QHT

DEF-STREAMS HEAT QLT

BLOCK B2 MIXER

PARAM PRES $=530$

BLOCK DRY1 MIXER 
BLOCK DRY2 MIXER

BLOCK DRYRMIX MIXER

;

BLOCK FEEDMIX MIXER

PARAM PRES $=25$

BLOCK RECMIX MIXER

BLOCK RECSPLT FSPLIT

FRAC H2RECYCL .1

BLOCK SANDSPLT FSPLIT

FRAC SANDPURG .0050

BLOCK B1 SEP

FRAC STREAM=KOWATER SUBSTREAM=MIXED COMPS=TAR H2 O2 N2 \& $\mathrm{CO} 2 \mathrm{CO} \mathrm{H} 2 \mathrm{O} \mathrm{CH} 4 \mathrm{H} 2 \mathrm{~S} \mathrm{NH} 3 \mathrm{COS} \mathrm{SO} 2 \mathrm{SO} 3 \mathrm{O} 2 \mathrm{SI} \mathrm{NO} 2 \mathrm{NO} \&$ PHENOL C6H6 $\mathrm{C} 2 \mathrm{H} 6 \mathrm{C} 2 \mathrm{H} 4 \mathrm{C} 2 \mathrm{H} 2$ CARBON SULFUR FRACS $=00$ \& 000010000000000000000

FRAC STREAM=KOWATER SUBSTREAM=CISOLID COMPS=02SI CARBON \& FRACS $=00$

FRAC STREAM=KOWATER SUBSTREAM=NC COMPS=WOOD ASH CHAR \& FRACS $=0 \quad 0 \quad 0$

;

BLOCK CHARSEP SEP

FRAC STREAM=CHAR SUBSTREAM=CISOLID COMPS=02SI CARBON \& FRACS $=1.01 .0$

FRAC STREAM $=$ CHAR SUBSTREAM $=$ NC COMPS $=$ WOOD ASH CHAR FRACS $=\&$ 1.01 .01 .0

FRAC STREAM=SYNGAS SUBSTREAM=MIXED COMPS=TAR H2 O2 N2 \& $\mathrm{CO} 2 \mathrm{CO} \mathrm{H} 2 \mathrm{O} \mathrm{CH} 4 \mathrm{H} 2 \mathrm{~S}$ NH3 $\mathrm{COS} \mathrm{SO} 2 \mathrm{SO} 3 \mathrm{O} 2 \mathrm{SI} \mathrm{NO} 2 \mathrm{NO} \&$ PHENOL C6H6 C2H6 C2H4 C2H2 CARBON SULFUR FRACS $=1.0 \&$ $1.01 .01 .01 .01 .01 .01 .01 .01 .01 .01 .01 .0 \&$ 1.01 .01 .01 .01 .01 .01 .01 .00 .00 .0

;

BLOCK COMBSPLT SEP

FRAC STREAM=ASHSAND SUBSTREAM=MIXED COMPS=TAR H2 O2 N2 \& $\mathrm{CO} 2 \mathrm{CO} \mathrm{H} 2 \mathrm{O} \mathrm{CH} 4 \mathrm{H} 2 \mathrm{~S} \mathrm{NH} 3 \mathrm{COS} \mathrm{SO} 2 \mathrm{SO} 3 \mathrm{O} 2 \mathrm{SI} \mathrm{NO} 2 \mathrm{NO} \&$

PHENOL C6H6 $\mathrm{C} 2 \mathrm{H} 6 \mathrm{C} 2 \mathrm{H} 4 \mathrm{C} 2 \mathrm{H} 2 \mathrm{CARBON}$ SULFUR FRACS $=.0 .0 \&$ $.0 .0 .0 .0 .0 .0 .0 .0 .0 .0 .01 .0 .0 .0 .0 \&$ \& .0 .0 .0 .0 .0 .0

FRAC STREAM=ASHSAND SUBSTREAM $=$ CISOLID COMPS=O2SI FRACS $=\&$ 1.0

FRAC STREAM=ASHSAND SUBSTREAM=NC COMPS=WOOD ASH CHAR \& FRACS $=.0$ 1.0 .0 
FRAC STREAM=DRIED SUBSTREAM=MIXED COMPS=TAR H2 O2 N2 \& $\mathrm{CO} 2 \mathrm{CO} \mathrm{H} 2 \mathrm{O} \mathrm{CH} 4 \mathrm{H} 2 \mathrm{~S}$ NH3 $\mathrm{COS} \mathrm{SO} 2 \mathrm{SO} 3 \mathrm{O} 2 \mathrm{SI} \mathrm{NO} 2 \mathrm{NO} \&$ PHENOL C6H6 C2H6 C2H4 C2H2 CARBON SULFUR FRACS $=00$ \& 000000000000000000000

FRAC STREAM=DRIED SUBSTREAM=CISOLID COMPS=O2SI CARBON \& FRACS $=0$

FRAC STREAM=DRIED SUBSTREAM=NC COMPS=WOOD ASH CHAR \& FRACS $=100$

BLOCK PSA SEP

FRAC STREAM=H2PURIFY SUBSTREAM=MIXED COMPS=TAR H2 O2 N2 \& $\mathrm{CO} 2 \mathrm{CO} \mathrm{H} 2 \mathrm{O} \mathrm{CH} 4 \mathrm{H} 2 \mathrm{~S} \mathrm{NH} 3 \mathrm{COS} \mathrm{SO} 2 \mathrm{SO} 3 \mathrm{O} 2 \mathrm{SI} \mathrm{NO} 2 \mathrm{NO} \&$ PHENOL C6H6 $\mathrm{C} 2 \mathrm{H} 6 \mathrm{C} 2 \mathrm{H} 4 \mathrm{C} 2 \mathrm{H} 2$ CARBON SULFUR FRACS $=0.85 \&$ 000000000000000000000

FRAC STREAM=H2PURIFY SUBSTREAM=CISOLID COMPS=02SI CARBON \& FRACS $=00$

FRAC STREAM=H2PURIFY SUBSTREAM=NC COMPS=WOOD ASH CHAR \& FRACS $=0 \quad 00$

BLOCK WOODSEP SEP

FRAC STREAM=WOODWAT SUBSTREAM=MIXED COMPS=TAR H2 O2 N2 \& $\mathrm{CO} 2 \mathrm{CO} \mathrm{H} 2 \mathrm{O} \mathrm{CH} 4 \mathrm{H} 2 \mathrm{~S} \mathrm{NH} 3 \mathrm{COS} \mathrm{SO} 2 \mathrm{SO} 3 \mathrm{O} 2 \mathrm{SI} \mathrm{NO} 2 \mathrm{NO} \&$ PHENOL C6H6 C2H6 C2H4 C2H2 CARBON SULFUR FRACS $=11$ \& 111111111111111111111

FRAC STREAM=WOODWAT SUBSTREAM=CISOLID COMPS=O2SI CARBON \& FRACS $=11$

FRAC STREAM=WOODWAT SUBSTREAM=NC COMPS=WOOD ASH CHAR \& FRACS=0 11

;

BLOCK AIRHEAT HEATER

PARAM TEMP $=60.0$ PRES $=0$

BLOCK B4 HEATER

PARAM TEMP $=190$ PRES $=0$

BLOCK B6 HEATER

PARAM PRES $=0$

BLOCK COMBCOOL HEATER

PARAM PRES $=0$

BLOCK HTCOOL HEATER

PARAM TEMP $=370<C>$ PRES $=0$

BLOCK REFHTR HEATER

PARAM TEMP $=800<C>$ PRES $=0$

BLOCK REFSTM HEATER

PARAM TEMP $=1000$ PRES $=0$

BLOCK SYNCOOLI HEATER

PARAM TEMP=195 PRES=0 


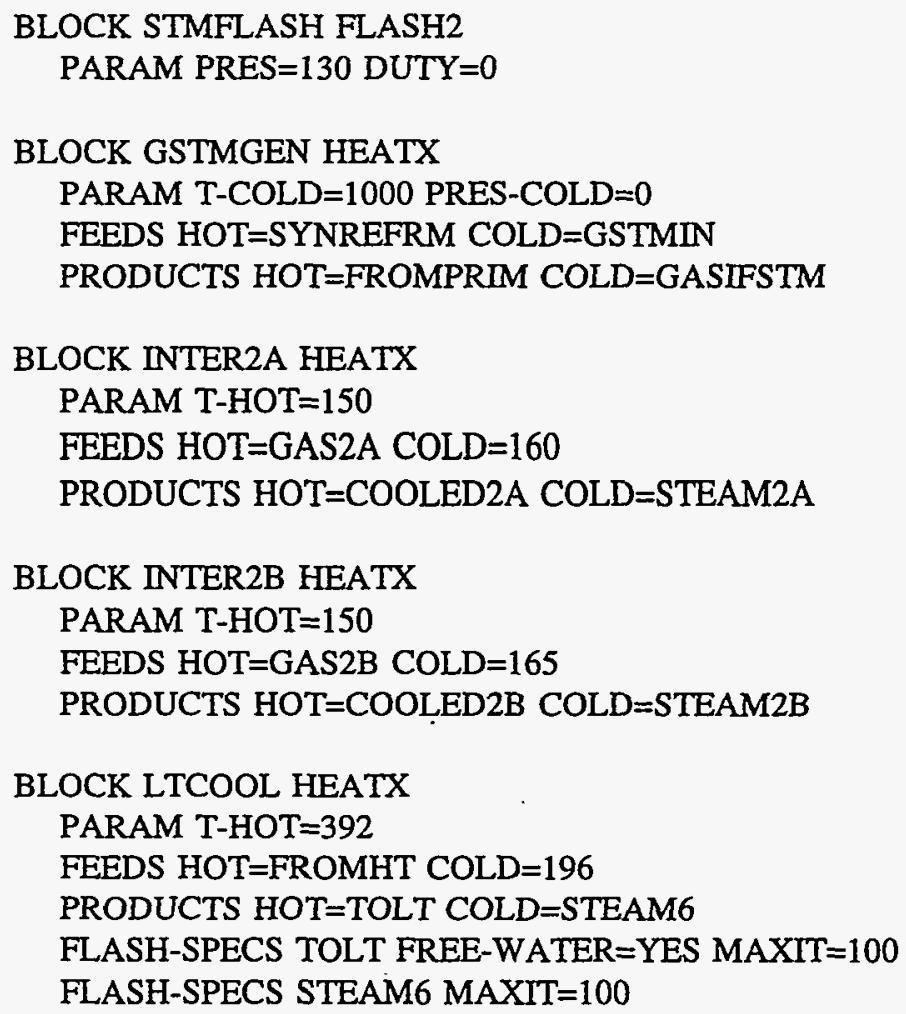

;This block is used to model the syngas cooler prior to compression. Note ; that this block is really only representative of SYNCOOI1 and REFHTR; ;SYNCOOL2 is a separate cooler, modelled by MODEL2.

\title{
BLOCK MODEL1 HEATX \\ PARAM T-HOT $=1472$ \\ FEEDS HOT $=$ HOTIN COLD $=$ COLDIN \\ PRODUCTS HOT=HOTOUT COLD=COLDOUT
}

;This block models the heat exchanger which connects blocks SYNCOOL2 ;DECANTHT. SYNCOOL1 is modeled by MODEL1.

\author{
BLOCK MODEL2 HEATX \\ PARAM T-COLD $=1000$ \\ FEEDS HOT $=\mathrm{HI}$ COLD $=\mathrm{CI}$ \\ PRODUCTS HOT $=$ HO $C O L D=C O$ \\ BLOCK PSACOOL HEATX \\ PARAM T-HOT $=75$ \\ FEEDS HOT $=$ FROMLT $C O L D=212$ \\ PRODUCTS HOT $=$ TOPSAA COLD=STEAM5 \\ DECANT-STREA HOT $=189$ \\ FLASH-SPECS TOPSAA FREE-WATER=YES \\ BLOCK STMGEN6 HEATX \\ PARAM T-HOT $=82$ \\ FEEDS HOT $=$ OFFFLUE2 COLD $=188$ \\ PRODUCTS $H O T=O F F F L U E 3$ COLD=STEAM4
}


BLOCK CHARFURN RSTOIC

PARAM TEMP $=1800.0$ PRES $=-1.0$

STOIC 1 MIXED H2 -1.0 / O2 -.50 / H2O 1.0

STOIC 2 MIXED O2 -1.0 / CISOLID CARBON -1.0 / MIXED \& $\mathrm{CO} 21.0$

STOIC 3 MLXED O2 -1.0 / CISOLID SULFUR -1.0 / MIXED \& $\mathrm{SO} 21.0$

CONV 1 MIXED H2 1.0

CONV 2 CISOLID CARBON 1.0

CONV 3 CISOLID SULFUR 1.0

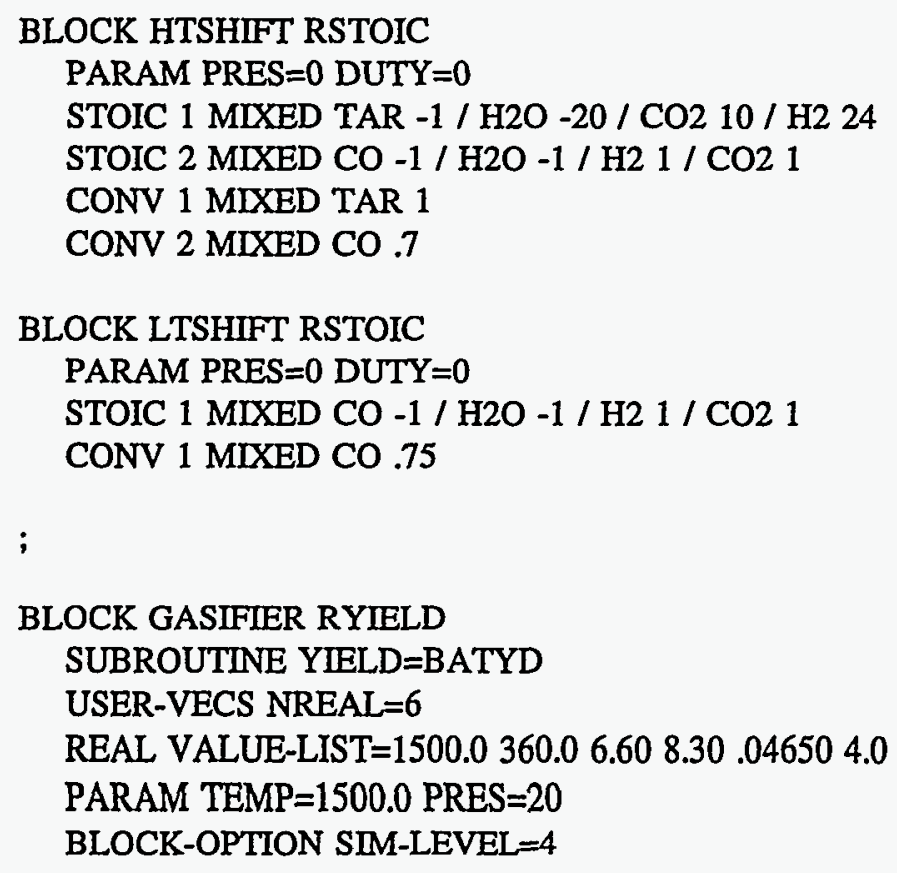

BLOCK LTSHIFT RSTOIC

PARAM PRES $=0$ DUTY $=0$

STOIC 1 MIXED CO -1/ H2O -1/ H2 1 / CO2 1

CONV 1 MLXED CO .75

;

BLOCK GASIFIER RYIELD

SUBROUTINE YIELD=BATYD

USER-VECS NREAL $=6$

REAL VALUE-LIST $=1500.0360 .06 .608 .30 .046504 .0$

PARAM TEMP $=1500.0$ PRES $=20$

BLOCK-OPTION SIM-LEVEL $=4$

BLOCK OFFCOMB RGIBBS

PARAM PRES $=0$

BLOCK PRIMARY RGIBBS

PARAM TEMP $=850<C>$ PRES $=0$ TAPP $=-20$

BLOCK B3 PUMP

PARAM PRES $=500$

BLOCK B5 PUMP

PARAM PRES $=530$

BLOCK B7 PUMP

PARAM PRES $=115$

BLOCK B13 PUMP

PARAM PRES $=115$

BLOCK PUMP1 PUMP

PARAM PRES $=180$ 


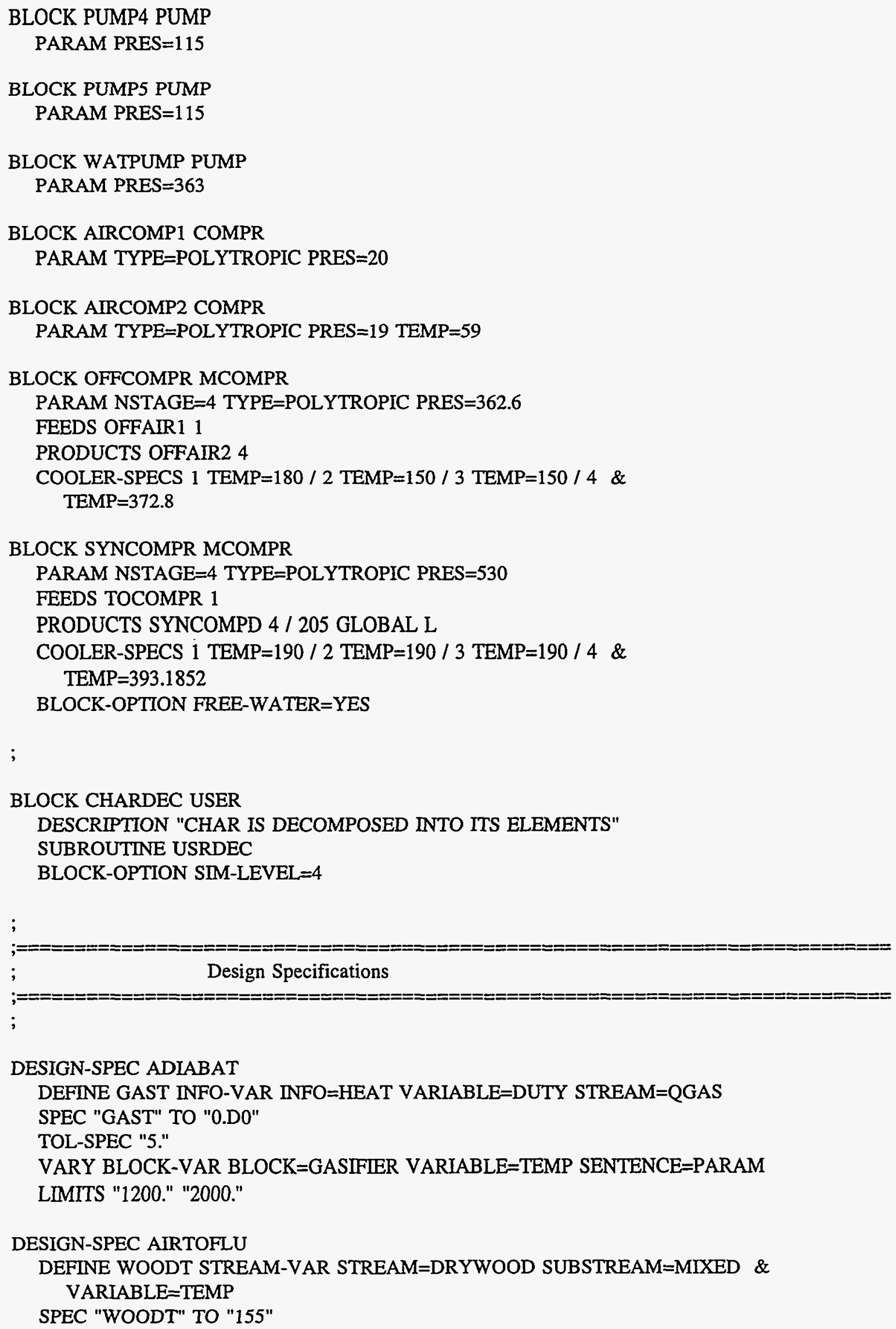


TOL-SPEC "1.0"

VARY STREAM-VAR STREAM=DRYRAIR SUBSTREAM=MIXED \& VARIABLE=MASS-FLOW

LIMITS "12" "40"

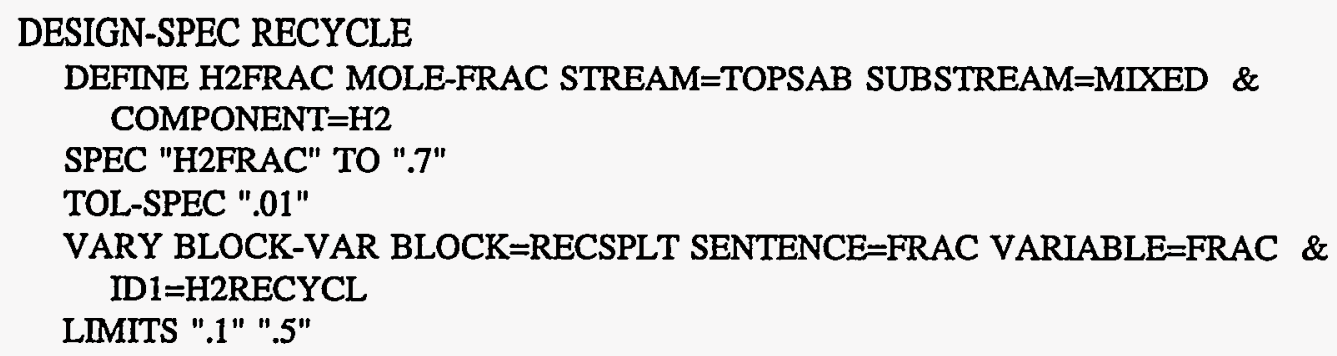


SENTENCE $=$ PARAM

DEFINE TLIST BLOCK-VAR BLOCK=GASIFIER VARIABLE=VALUE-LIST \& SENTENCE=REAL, ELEMENT $=1$

F $\quad$ TLIST $=$ TGAS

F WRITE(NHSTRY, ${ }^{*}$ ) WRITE: TLIST $=$ ',TLIST

F WRITE(NHSTRY, ${ }^{*}$ ) WRITE: TGAS = 'TGAS

READ-VARS TGAS

WRITE-VARS TLIST

FORTRAN OFFAIR

DEFINE H2 MOLE-FLOW STREAM=OFFGAS SUBSTREAM=MIXED \& COMPONENT $=\mathrm{H} 2$

DEFINE CO MOLE-FLOW STREAM=OFFGAS SUBSTREAM=MIXED \& COMPONENT $=\mathrm{CO}$

DEFINE CH4 MOLE-FLOW STREAM=OFFGAS SUBSTREAM=MIXED \& COMPONENT $=\mathrm{CH} 4$

DEFINE C2H6 MOLE-FLOW STREAM=OFFGAS SUBSTREAM=MIXED \& COMPONENT $=\mathrm{C} 2 \mathrm{H} 6$

DEFINE C2H4 MOLE-FLOW STREAM=OFFGAS SUBSTREAM=MIXED \& COMPONENT $=\mathrm{C} 2 \mathrm{H} 4$

DEFINE C2H2 MOLE-FLOW STREAM=OFFGAS SUBSTREAM=MIXED \& COMPONENT $=\mathrm{C} 2 \mathrm{H} 2$

DEFINE AIRFLO STREAM-VAR STREAM=OFFAIR1 SUBSTREAM=MIXED \& VARIABLE=MOLE-FLOW

DEFINE O2FRAC MOLE-FRAC STREAM=OFFAIR1 SUBSTREAM=MIXED \& COMPONENT $=02$

F $\quad$ O2MOL $=(.5 * \mathrm{H} 2+.5 * \mathrm{CO}+2 * \mathrm{CH} 4+3.5 * \mathrm{C} 2 \mathrm{H} 6+3 * \mathrm{C} 2 \mathrm{H} 4+2.5 * \mathrm{C} 2 \mathrm{H} 2)$

F AIRFLO $=1.15 *$ O2MOL/O2FRAC

EXECUTE BEFORE BLOCK OFFCOMB

FORTRAN PRESDROP

DEFINE P1 STREAM-VAR STREAM=SYNCOMPD SUBSTREAM=MIXED \& VARIABLE=PRES

DEFINE HTPRES BLOCK-VAR BLOCK=HTSHIFT VARIABLE=PRES \& SENTENCE=PARAM

DEFINE LTPRES BLOCK-VAR BLOCK=LTSHIFT VARIABLE=PRES \& SENTENCE=PARAM

DEFINE PRIMP BLOCK-VAR BLOCK=PRIMARY VARIABLE $=$ PRES \& SENTENCE $=$ PARAM

$\mathrm{F} \quad \mathrm{PRIMP}=0.95 * \mathrm{P} 1$

F HTPRES $=0.85 *$ PRIMP

F LTPRES $=0.85 *$ HTPRES

EXECUTE AFTER BLOCK PRIMARY

FORTRAN REFSTM

DEFINE STM MOLE-FLOW STREAM=REFSTMA SUBSTREAM=MIXED \& COMPONENT $=\mathrm{H} 2 \mathrm{O}$

DEFINE TAR MOLE-FLOW STREAM=TOREFHOT SUBSTREAM=MIXED \& COMPONENT $=$ TAR

DEFINE CO MOLE-FLOW STREAM=TOREFHOT SUBSTREAM=MIXED \& COMPONENT $=\mathrm{CO}$

DEFINE CH4 MOLE-FLOW STREAM=TOREFHOT SUBSTREAM=MIXED \& COMPONENT $=\mathrm{CH} 4$

DEFINE C2H6 MOLE-FLOW STREAM=TOREFHOT SUBSTREAM=MIXED \& 
COMPONENT $=\mathrm{C} 2 \mathrm{H} 6$

DEFINE C2H4 MOLE-FLOW STREAM=TOREFHOT SUBSTREAM=MIXED \& COMPONENT $=\mathrm{C} 2 \mathrm{H} 4$

DEFINE C2H2 MOLE-FLOW STREAM=TOREFHOT SUBSTREAM=MIXED \& COMPONENT $=\mathrm{C} 2 \mathrm{H} 2$

DEFINE EXIST MOLE-FLOW STREAM=TOREFHOT SUBSTREAM=MIXED \& COMPONENT $=\mathrm{H} 2 \mathrm{O}$

F $\quad \mathrm{STM}=3 *(10 * \mathrm{TAR}+\mathrm{CO}+1 * \mathrm{CH} 4+2 * \mathrm{C} 2 \mathrm{H} 6+2 * \mathrm{C} 2 \mathrm{H} 4+2 * \mathrm{C} 2 \mathrm{H} 2)$-EXIST EXECUTE BEFORE BLOCK PRIMARY

FORTRAN SETCSEP

DEFINE TEMPIN STREAM-VAR STREAM=WOODGAS SUBSTREAM=MIXED \& VARIABLE=TEMP

DEFINE TSEP BLOCK-VAR BLOCK=CHARSEP VARIABLE=TEMP \& SENTENCE=FLASH-SPECS IDI=CHAR

DEFINE TSEPG BLOCK-VAR BLOCK=CHARSEP VARIABLE=TEMP \& SENTENCE=FLASH-SPECS $\mathrm{DD} 1=$ SYNGAS

F TSEP $=$ TEMPIN

F TSEPG $=$ TEMPIN

READ-VARS TEMPIN

WRITE-VARS TSEP TSEPG

FORTRAN STEAMAMT

DEFINE STEAM MASS-FLOW STREAM=GASIFSTM SUBSTREAM=MIXED \& COMPONENT $=\mathrm{H} 2 \mathrm{O}$

DEFINE WOOD MASS-FLOW STREAM=WOOD SUBSTREAM=NC \& COMPONENT $=$ WOOD

F $\quad$ STEAM $=0.4 *$ WOOD

READ-VARS WOOD

WRITE-VARS STEAM

FORTRAN WOODDRY

DEFINE REALNC STREAM-VAR STREAM=WOOD SUBSTREAM=NC \& VARIABLE=MASS-FLOW

DEFINE REALMI STREAM-VAR STREAM=WOOD SUBSTREAM=MIXED \& VARIABLE=MASS-FLOW

DEFINE REALCI STREAM-VAR STREAM=WOOD SUBSTREAM=CISOLID \& VARIABLE=MASS-FLOW

DEFINE NEWNC STREAM-VAR STREAM=ARWOOD SUBSTREAM=NC \& VARIABLE=MASS-FLOW

DEFINE NEWMIX STREAM-VAR STREAM=ARWOOD SUBSTREAM=MIXED \& VARIABLE=MASS-FLOW

DEFINE NEWCI STREAM-VAR STREAM=ARWOOD SUBSTREAM=CISOLID \& VARIABLE=MASS-FLOW

DEFINE NEWH2O MASS-FLOW STREAM=ARWOOD SUBSTREAM=MIXED \& COMPONENT $=\mathrm{H} 2 \mathrm{O}$

F NEWNC $=$ REALNC

F NEWH2O $=0.78 *$ REALNC

F NEWMIX = REALMI + NEWH2O

F NEWCI $=$ REALCI

EXECUTE BEFORE BLOCK WOODSEP 


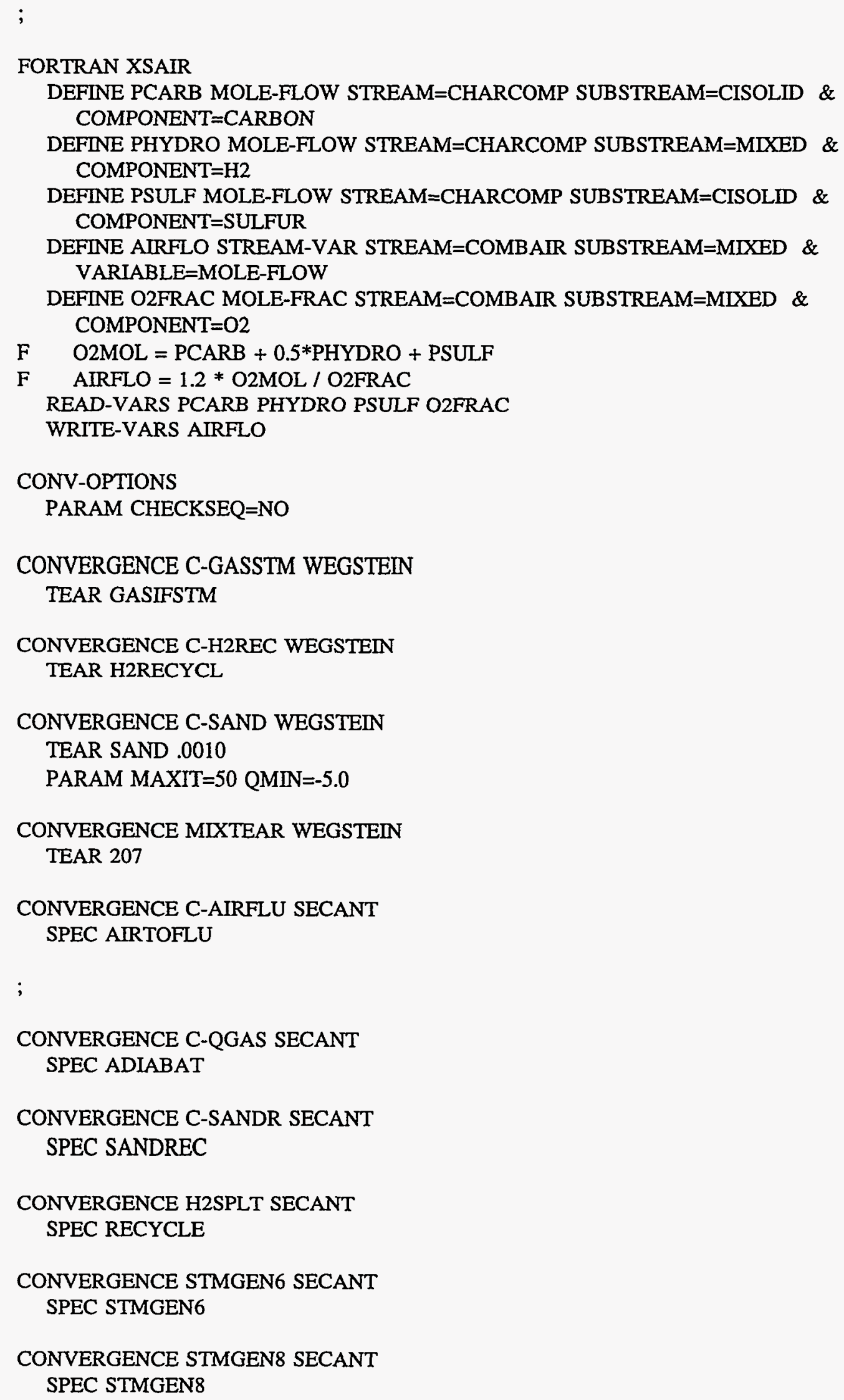


SEQUENCE S-1 STEAMAMT C-GASSTM C-SAND FEEDMIX C-QGAS GASTEMP \& GASIFIER (RETURN C-QGAS) SETCSEP CHARSEP CHARDEC XSAIR \& AIRCOMP1 COMBAIRT AIRHEAT C-SANDR CHARFURN \& (RETURN C-SANDR) COMBSPLT SANDSPLT (RETURN C-SAND) \& SYNCOOL1 MIXTEAR B1 B5 SYNCOMPR B2 (RETURN MIXTEAR) \& REFHTR REFSTM WATPUMP REFSTM PRESDROP PRIMARY GSTMGEN \& (RETURN C-GASSTM) C-AIRFLU AIRCOMP2 DRYRMIX WOODDRY \& WOODSEP DRY1 DRY2 DRYRSEP (RETURN C-AIRFLU) HTCOOL \& HTSHIFT STMGEN8 B3 LTCOOL (RETURN STMGEN8) LTSHIFT B7 \& PSACOOL H2SPLT C-H2REC RECMIX PSA RECSPLT \& (RETURN C-H2REC) (RETURN H2SPLT) OFFAIR OFFCOMPR OFFCOMB \& COMBCOOL B13 STMGEN6 MODEL1 MODEL2 PUMP1 B4 B6 \& STMFLASH PUMP4 INTER2A PUMP5 INTER2B

STREAM-REPOR ZEROFLOW MOLEFLOW MASSFLOW MOLEFRAC MASSFRAC \& NOCOMP-ATTR

PROPERTY-REP NOPARAMS

REPORT-SCALE

DEFINE WOOD STREAM-VAR STREAM=WOOD SUBSTREAM=NC \& VARIABLE=MASS-FLOW

SCALE "WOOD" TO "1"

PROP-TABLE PT-1 PROPS

STREAM COMBAIR

VARY TEMP

RANGE LOWER $=100.0$ UPPER $=2400.0 \mathrm{INCR}=100.0$

TABULATE "PROPERTIES TABLE FOR CONV. COMPS" PROPERTIES=PS-1

PROP-TABLE PT-2 PROPS

STREAM WOOD

VARY TEMP

RANGE LOWER $=100.0$ UPPER $=2400.0$ INCR $=100.0$

TABULATE "PROPS FOR NC COMPS" PROPERTIES=PS-2 
C \$ \#2 BY: MKMANN 6/08/94 MODIFIED TO MODEL THE BATTELLE GASIFIER

C\$ \#1 BY: KRCRAIG 5/21/93 NEW

$\mathrm{C}$

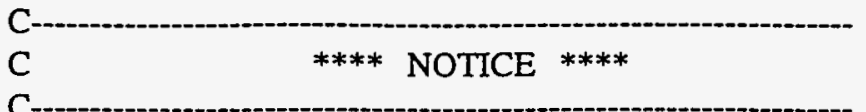

$\mathrm{C}$

$\mathrm{C}$

\%\%\%\%\%\%\%\%\%\%\%\%\%\%\%\%\%\%\%\%\%\%\%\%\%\%\%\%\%\%\%\%\%\%\%\%\%\%\%\%\%\%\%\%\%\%\%\%\%\%\%\%\%\%\%\% $\% \% \% \% \% \% \% \% \% \% \% \%$

$\mathrm{C}$

C THIS CODE IS PART OF THE SYSTEM DEVELOPED AT

C NATIONAL RENEWABLE ENERGY LABORATORY, GOLDEN, COLORADO

C

$\mathrm{C}$

\%\%\%\%\%\%\%\%\%\%\%\%\%\%\%\%\%\%\%\%\%\%\%\%\%\%\%\%\%\%\%\%\%\%\%\%\%\%\%\%\%\%\%\%\%\%\%\%\%\%\%\%\%\%\%\% $\% \% \% \% \% \% \% \% \% \% \% \%$

$\mathrm{C}$

C

C

SUBROUTINE BATYD (SIN ,SOUT , NSUBS,IDXSUB,ITYPE,NINT,INT,NREAL,

1 REAL,IDS,NPO,NBOPST,NIW,IW,NW,W)

C

C

C

C

$\mathrm{C}$

C

C

C

C

C

$\mathrm{C}$

C

C

C

C

C

C

C

C SIN I/O $R$ INLET MATERIAL STREAM VECTOR

$C$ SOUT $O$ R OUTLET MATERIAL STREAM VECTOR

$C$ NSUBS I I NUMBER OF SUBSTREAMS

$C$ IDXSUB I I NSUBS SUBSTREAM INDEX VECTOR

C ITYPE I I NSUBS SUBSTREAM TYPE VECTOR

C NINT I I LENGTH OF INTEGER VECTOR

C INT I/O I NINT INTEGER VECTOR

C NREAL I I LENGTH OF REAL VECTOR

C REAL I R NREAL REAL ARRAY

C REAL(1) I $R$ OUTLET TEMPERATURE

C REAL(2) I R OUTLET PRESSURE

C IDS I I 2,NCC ID VECTOR

C NPO I I NUMBER OF PHYSICAL PROPERTY OPTIONS

C NBOPST I I 3,NPO PHYSICAL PROPERTY OPTION SET POINTERS 


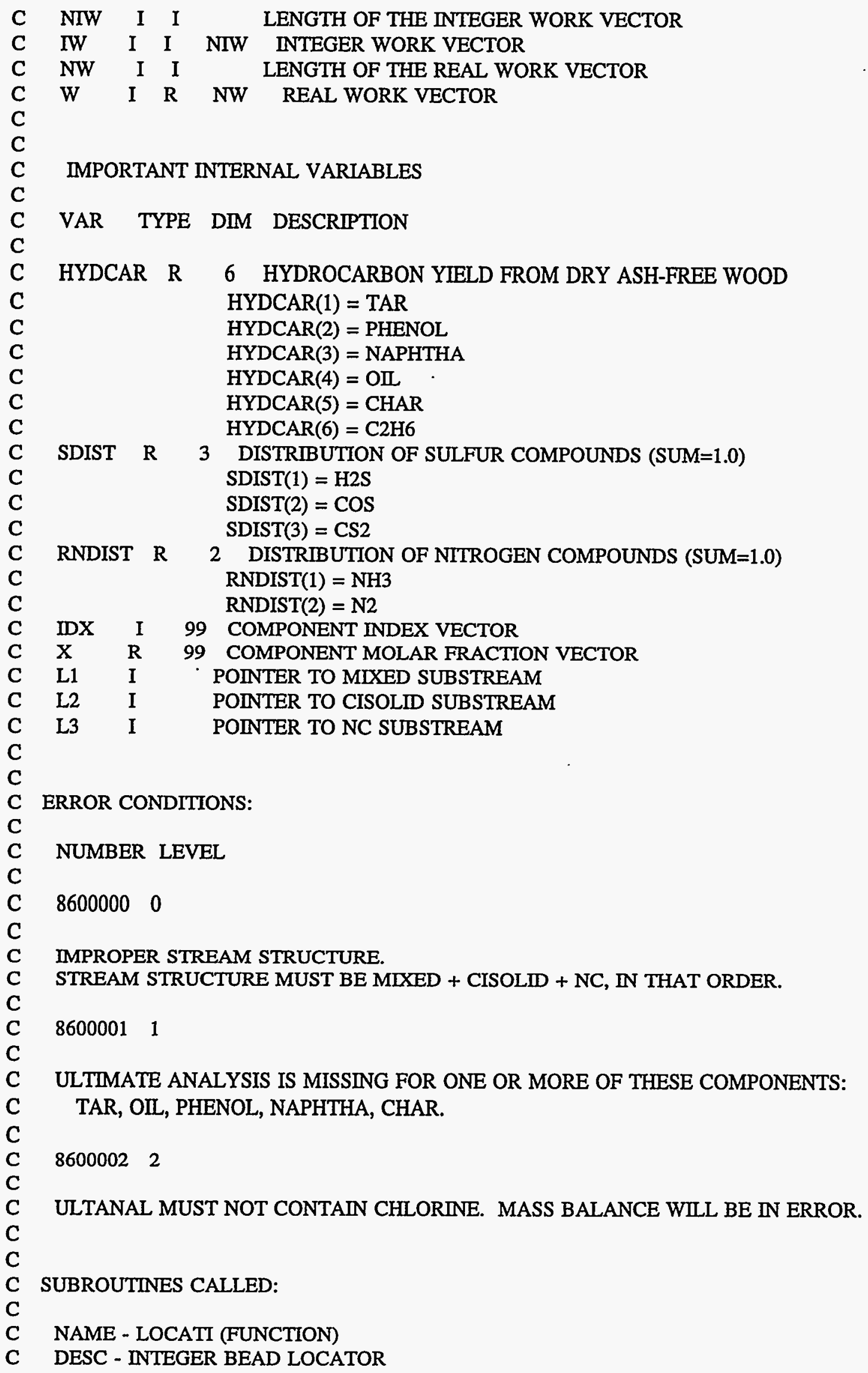


C

C NAME - LOCATS

C DESC - STREAM BEAD LOCATOR

C

C NAME - APSCPY

C DESC - STREAM COPIER

C

C NAME - UCONV1

C DESC - CONVERTS VALUE TO SI UNITS

C

C NAME - NSQCC

C DESC - FINDS SEQUENCE NUMBER OF A CONVENTIONAL COMPONENT

C

C NAME - NSQNCC

C DESC - FINDS SEQUENCE NUMBER OF A NONCONVENTIONAL COMPONENT

C

NAME - CPACK

DESC - CONVENTIONAL PHASES PACKING

NAME - AVEMW (FUNCTION)

DESC - AVERAGE SUBSTREAM MOLECULAR WEIGHT

NAME - TOTENT

DESC - TOTAL STREAM ENTHALPY

NAME - FLASH

C DESC - GENERAL PURPOSE FLASH INTERFACE ROUTINE

C

C NAME - MERRPT (FUNCTION)

C DESC - ERROR MESSAGE CHECKING

C

C NAME - ERROR

C DESC - ERROR HANDLING ROUTINE

C

C

C

C

C

C

C $\quad * * * * * * * * * * * * * * * * * * * * * * * * * * * * * * * * * * * * * * * * * * * * * * * * * * * * * *$

C

THE COMPONENTS LISTED BELOW ARE REQUIRED. ALL OTHERS ARE CONSIDERED INERT.

WOOD, CHAR, TAR, OIL, PHENOL, AND NAPHTHA ARE EXPECTED TO HAVE ULTIMATE ANALYSES. ANY CHLORINE IN THE ULTIMATE ANALYSES WILL BE IGNORED, RESULTING IN A MASS BALANCE ERROR. TAR, OIL, PHENOL, AND NAPHTHA SHOULD BE IN THE MIXED SUBSTREAM. THE ASSUMED STREAM STRUCTURE IS MIXED + CISOLID + NC. 


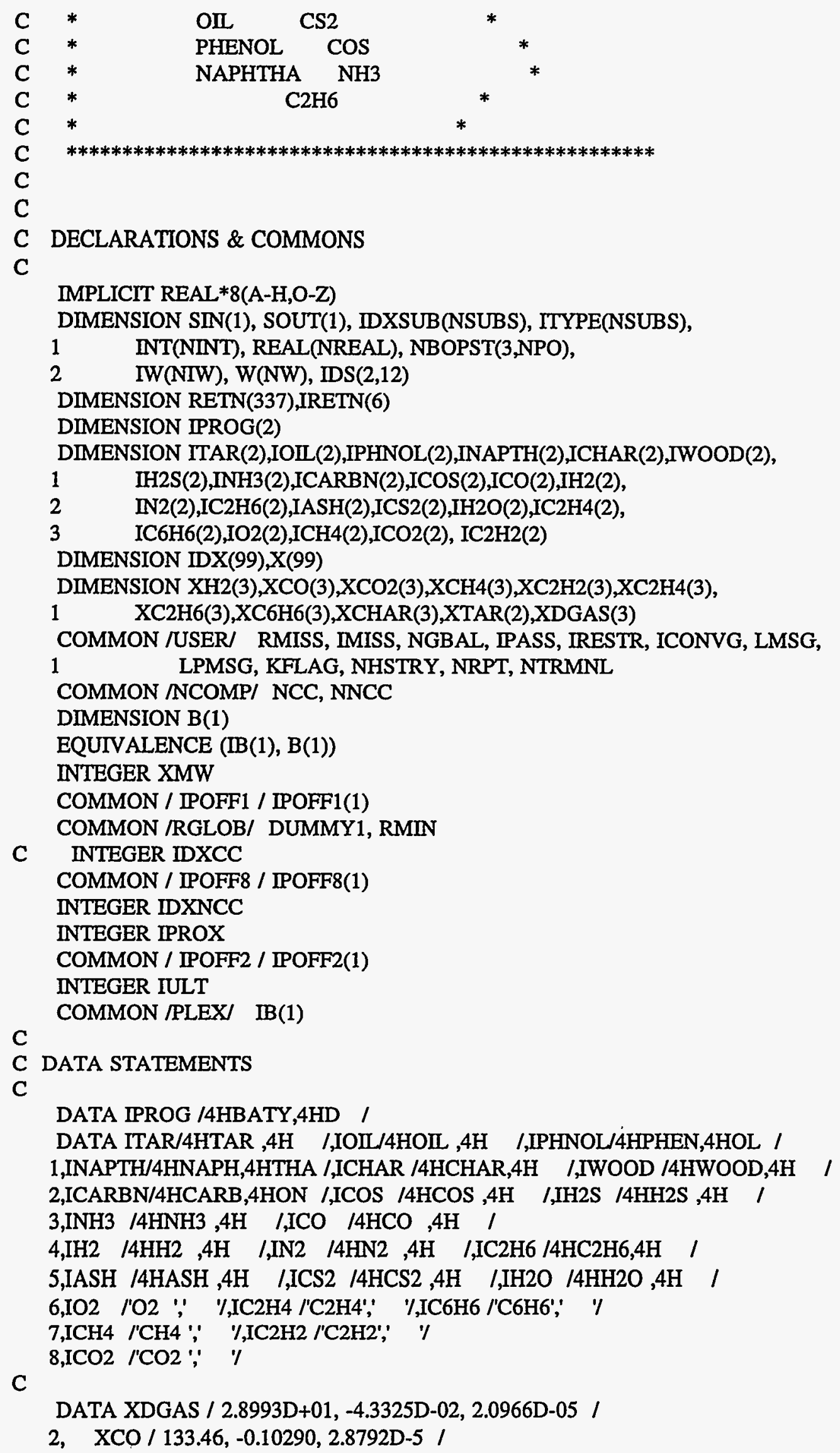




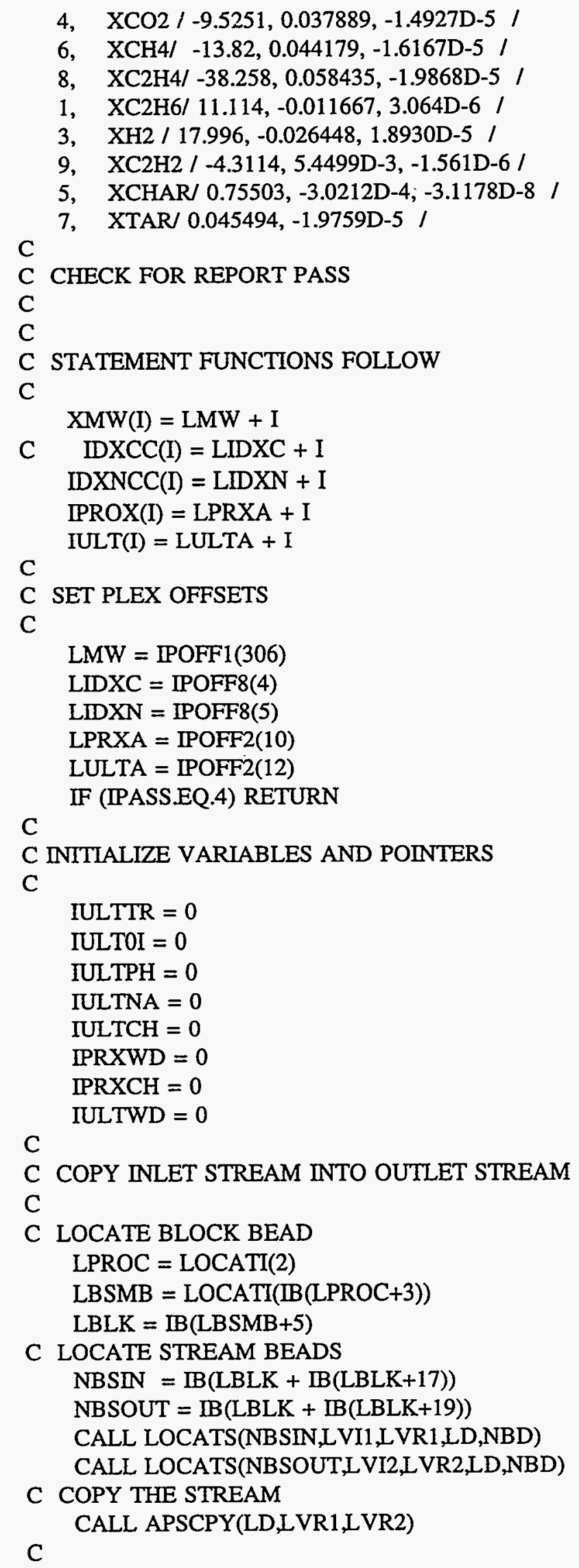


C CHECK FOR IMPROPER STREAM STRUCTURE

C

IF (NSUBS.NE.3) GOTO 820

C

IF (ITYPE(1).NE.1 .OR. ITYPE(2).NE.2 .OR. ITYPE(3).NE.3) GOTO 820

C SET OUTLET TEMPERATURE AND PRESSURE (IN SI UNITS)

C

TOUTF $=\operatorname{REAL}(1)$

TOUT $=$ REAL $(1)$

POUT $=$ REAL $(2)$

CALL UCONV1(22,TOUT)

CALL UCONV1(20,POUT)

IF (POUTLE.0.0) POUT $=$ SIN(NNCC+3)+POUT

C

C FIND COMPONENT INDEX NUMBERS

C

CALL NSQCC(ITAR,NTAR)

C CALL NSQCC(IOIL,NOIL)

C CALL NSQCC(IPHNOL,NPHNOL)

C CALL NSQCC(INAPTH,NNAPTH)

CALL NSQCC(ICARBN,NCARBN)

C CALL NSQCC(ICOS,NCOS)

C CALL NSQCC(ICS2,NCS2)

CALL NSQCC(IH2S,NH2S)

CALL NSQCC(IH2O,NH2O)

CALL NSQCC(INH3,NNH3)

CALL NSQCC(ICO,NCO)

CALL NSQCC(ICO2,NCO2)

CALL NSQCC(IH2,NH2)

CALL NSQCC(IN2,NN2)

CALL NSQCC(IO2,NO2)

CALL NSQCC(IC2H6,NC2H6)

CALL NSQCC(IC2H4,NC2H4)

CALL NSQCC(IC2H2,NC2H2)

CALL NSQCC(IC6H6,NC6H6)

CALL NSQCC(ICH4,NCH4)

CALL NSQNCC(IWOOD,NWOOD)

CALL NSQNCC(IASH,NASH)

C

CALL NSQNCC(ICHAR,NCHAR)

C ATOMIC (NOT MOLECULAR) WEIGHTS FOR CARBON, HYDROGEN, NITROGEN,

C SULFUR, AND OXYGEN.

C

$\mathrm{CAW}=\mathrm{B}(\mathrm{XMW}(\mathrm{NCARBN}))$

$\mathrm{HAW}=\mathrm{B}(\mathrm{XMW}(\mathrm{NH} 2)) / 2$

$\mathrm{RNAW}=\mathrm{B}(\mathrm{XMW}(\mathrm{NN} 2)) / 2$

SAW $=32.064$

C

$\mathrm{OAW}=16.0$

C FIND OUT WHERE ATTRIBUTES ARE STORED FOR ATTRIBUTED COMPONENTS.

C

$$
\begin{gathered}
\text { DO } 150 \text { I }=1, \text { NSUBS } \\
\text { ILOC }=\text { ITYPE(I) } \\
\text { NCT }=\text { NCC }
\end{gathered}
$$




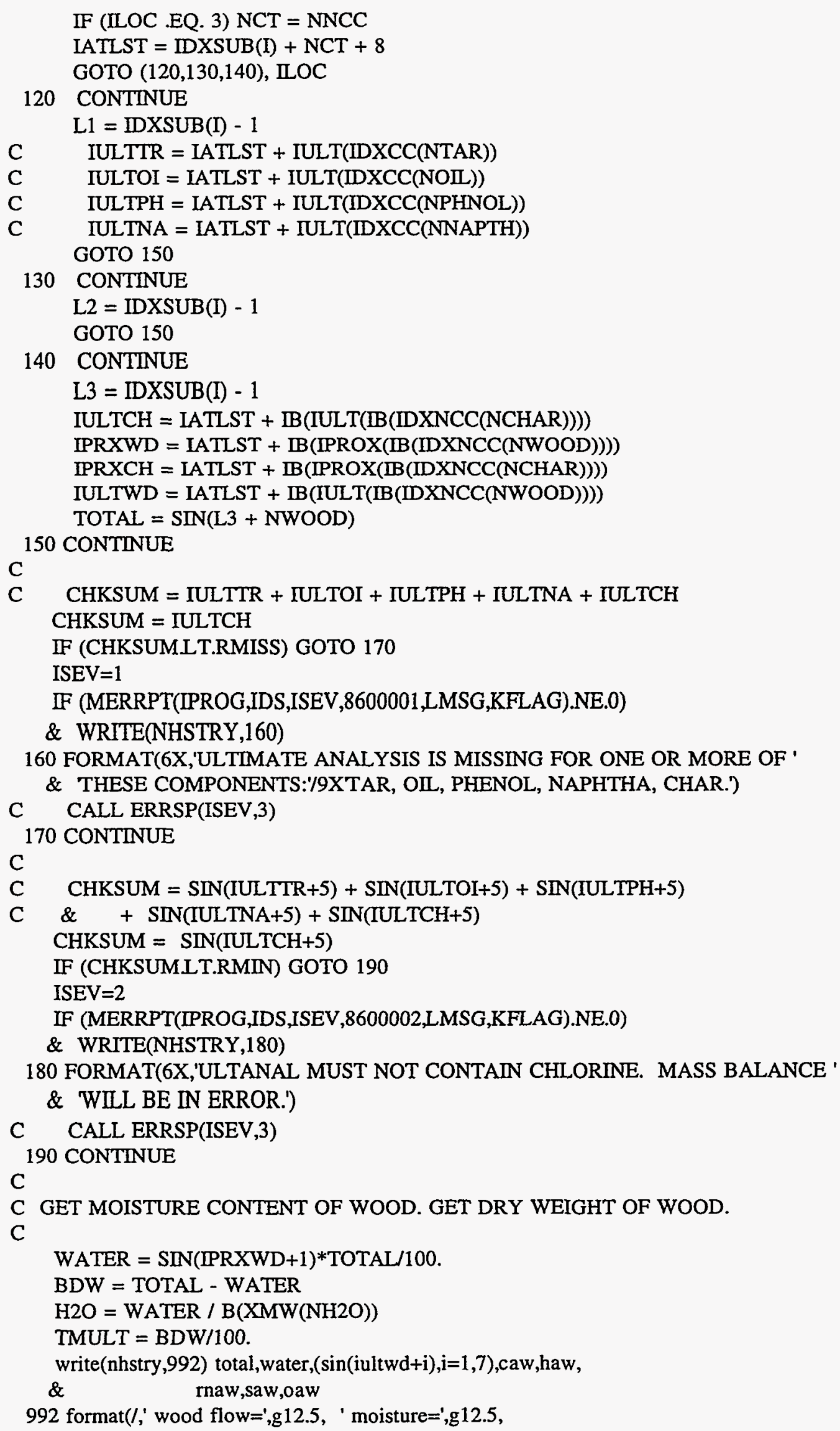




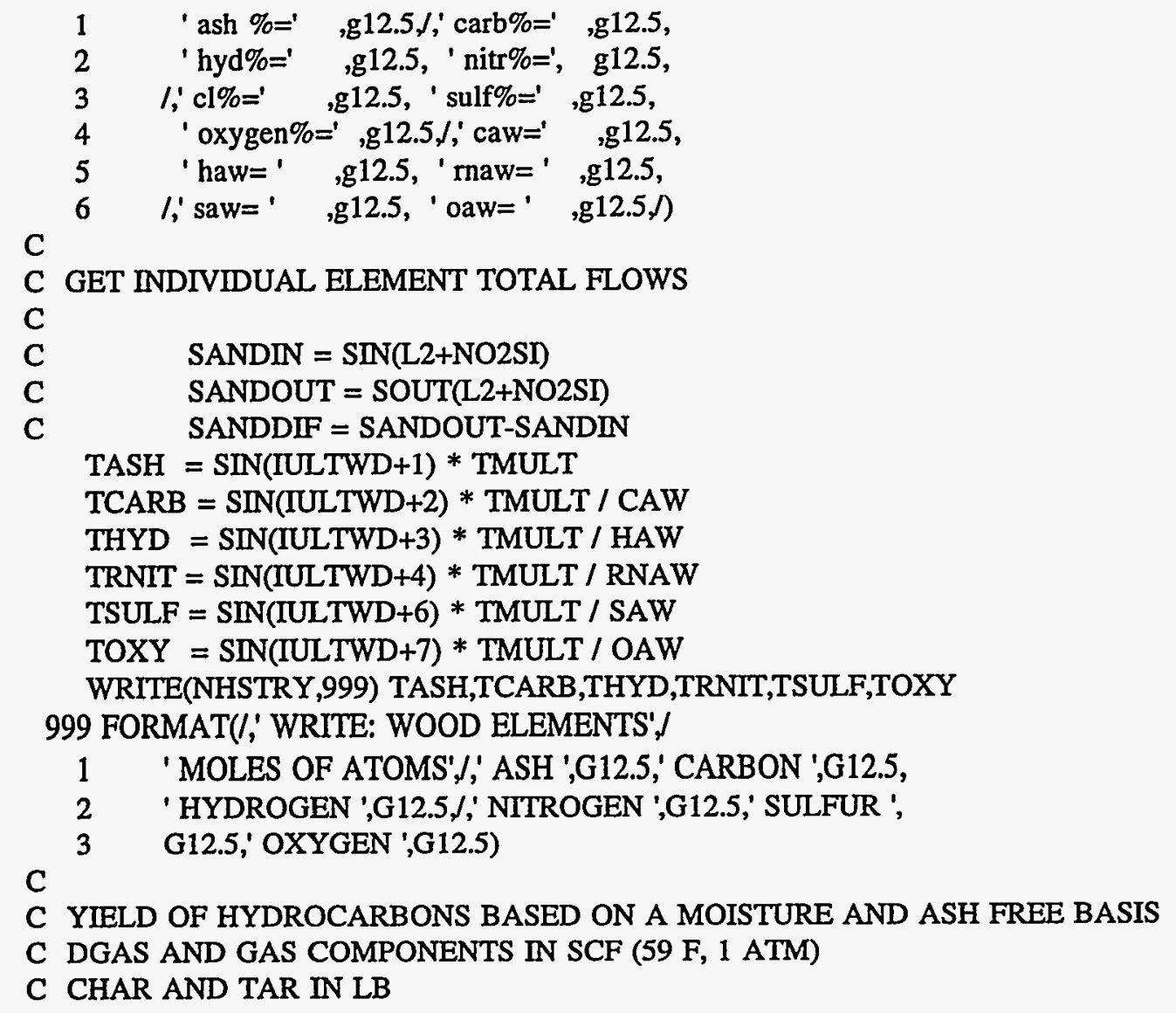

$\mathrm{ZMAF}=\mathrm{BDW}-\mathrm{TASH}$

C ZMAF = MOISTURE AND ASH FREE WOOD (KG/SEC)

WRITE(NHSTRY,*) ZMAF = ',ZMAF

$\mathrm{ZLBMAF}=\mathrm{ZMAF} * 2.20462 * 3600$

C ZLBMAF = MOISTURE AND ASH FREE WOOD (LB/HR)

WRITE(NHSTRY, ${ }^{*}$ ) ZLBMAF $=$ ',ZLBMAF

$\mathrm{ZLBBDW}=\mathrm{BDW} * 2.20462 * 3600$

WRITE(NHSTRY, $*$ ) ZLBBDW $=$ ',ZLBBDW

$\mathrm{T} 2=\mathrm{TOUTF}^{* *} 2$

$\mathrm{T} 1=\mathrm{TOUTF}$

WRITE(NHSTRY,*) TOUT $=$ ',TOUT

WRITE(NHSTRY,*) T1 = ',T1

WRITE(NHSTRY,*) T2 = ',T2

DGAS $=(X D G A S(1)+\mathrm{T} 1 * X D G A S(2)+\mathrm{T} 2 * \mathrm{XDGAS}(3)) * \mathrm{ZLBMAF}$

WRITE(NHSTRY, $*$ ) 'DGAS IN SCF $=$ ',DGAS

WRITE(NHSTRY, $*$ ) 'MAF IN LB = ',ZLBMAF

$\mathrm{H} 2=(\mathrm{XH} 2(1)+\mathrm{T} 1 * \mathrm{XH} 2(2)+\mathrm{T} 2 * \mathrm{XH} 2(3)) * \mathrm{DGAS} / 100$

write(nhstry,*) ' WRITE: bdw= ',bdw,' h2= ',h2, ' DGAS= ',DGAS

$\mathrm{CO}=(\mathrm{XCO}(1)+\mathrm{T} 1 * \mathrm{XCO}(2)+\mathrm{T} 2 * \mathrm{XCO}(3)) * \mathrm{DGAS} / 100$

write(nhstry,*) ' WRITE: $\mathrm{CO}(\mathrm{scf})=$ ',CO

$\mathrm{CO} 2=(\mathrm{XCO} 2(1)+\mathrm{T} 1 * \mathrm{XCO} 2(2)+\mathrm{T} 2 * \mathrm{XCO} 2(3)) * \mathrm{DGAS} / 100$

write(nhstry, ${ }^{*}$ ) ' WRITE: $\mathrm{CO} 2$ (scf) $=$ ', $\mathrm{CO} 2$

$\mathrm{CH} 4=(\mathrm{XCH} 4(1)+\mathrm{T} 1 * \mathrm{XCH} 4(2)+\mathrm{T} 2 * \mathrm{XCH} 4(3)) * \mathrm{DGAS} / 100$

write(nhstry,*) ' WRITE: CH4(scf)=',CH4

$\mathrm{C} 2 \mathrm{H} 2=(\mathrm{XC} 2 \mathrm{H} 2(1)+\mathrm{T} 1 * \mathrm{XC} 2 \mathrm{H} 2(2)+\mathrm{T} 2 * \mathrm{XC} 2 \mathrm{H} 2(3)) * \mathrm{DGAS} / 100$

write(nhstry, ${ }^{*}$ ) ' WRITE: C2H2(scf)=',C2H2 
$\mathrm{C} 2 \mathrm{H} 4=(\mathrm{XC} 2 \mathrm{H} 4(1)+\mathrm{T} 1 * \mathrm{XC} 2 \mathrm{H} 4(2)+\mathrm{T} 2 * \mathrm{XC} 2 \mathrm{H} 4(3)) * \mathrm{DGAS} / 100$

write(nhstry, $)^{\prime}$ ' WRITE: C2H4(scf) $=$ ', C2H4

$\mathrm{C} 2 \mathrm{H} 6=(\mathrm{XC} 2 \mathrm{H} 6(1)+\mathrm{T} 1 * \mathrm{XC} 2 \mathrm{H} 6(2)+\mathrm{T} 2 * \mathrm{XC} 2 \mathrm{H} 6(3)) * \mathrm{DGAS} / 100$

write(nhstry,*) ' WRITE: C2H6(scf)=',C2H6

$\mathrm{CHAR}=(\mathrm{XCHAR}(1)+\mathrm{T} 1 * \mathrm{XCHAR}(2)+\mathrm{T} 2 * \mathrm{XCHAR}(3)) * \mathrm{ZLBBDW}$

WRITE(NHSTRY,*) 'WRITE: CHAR (LB) = ',CHAR

TAR $=(\operatorname{XTAR}(1)+\mathrm{T} 1 * \mathrm{XTAR}(2)) * \mathrm{ZLBBDW}$

write(nhstry,*) ' WRITE: TAR(LB)=',TAR

C CONVERT PRODUCT GAS FLOWS IN SCF AND TAR AND CHAR IN LB TO MOLAR BASI

$\mathrm{H} 2 \mathrm{MOL}=\mathrm{H} 2 / 379.4630 / 2.20462 / 3600$

write(nhstry,*) ' WRITE: mwh2= ',B(xmw(nh2)),' h2mol= ',h2mol

COMOL $=\mathrm{CO} / 379.4630 / 2.20462 / 3600$

write(nhstry,*) ' WRITE: mwCO= ',B(xmw(nCO)),' COmol= ',COmol

$\mathrm{CO} 2 \mathrm{MOL}=\mathrm{CO} 2 / 379.4630 / 2.20462 / 3600$

write(nhstry,*) ' WRITE: mwCO2 = ',B(xmw(nCO2)),' $\mathrm{CO} 2 \mathrm{~mol}=$ ',CO2mol

$\mathrm{CH} 4 \mathrm{MOL}=\mathrm{CH} 4 / 379.4630 / 2.20462 / 3600$

write(nhstry,*) ' WRITE: mwCH4 = ',B(xmw(nCH4)),' CH4mol= ',CH4mol

$\mathrm{C} 2 \mathrm{H} 2 \mathrm{MOL}=\mathrm{C} 2 \mathrm{H} 2 / 379.4630 / 2.20462 / 3600$

$\mathrm{C} 2 \mathrm{H} 4 \mathrm{MOL}=\mathrm{C} 2 \mathrm{H} 4 / 379.4630 / 2.20462 / 3600$

$\mathrm{C} 2 \mathrm{H} 6 \mathrm{MOL}=\mathrm{C} 2 \mathrm{H} 6 / 379.4630 / 2.20462 / 3600$

C $\quad \mathrm{C} 6 \mathrm{H} 6 \mathrm{MOL}=\mathrm{C} 6 \mathrm{H} 6 / 379.4630 / 2.20462 / 3600$

TARMOL $=$ TAR/B $(X M W(N T A R)) / 2.20462 / 3600$

write(nhstry, ${ }^{*}$ ) ' WRITE: mwTAR = ',B(xmw(nTAR)),' TARmol= ',TARmol

if (h2mol .lt. 0.d0) h2mol = 0.d0

if (h2mol .lt. 0.d0) WRITE(NHSTRY,*) ' WRITE: H2MOL = 0 (407)'

if (comol .lt. $0 . d 0) \mathrm{comol}=0 . \mathrm{d} 0$

if (comol .lt. 0.d0) WRITE(NHSTRY, ${ }^{*}$ ' WRITE: COMOL $=0$ (409) '

if (co2mol .lt. $0 . \mathrm{d} 0) \mathrm{co} 2 \mathrm{~mol}=0 . \mathrm{d} 0$

if (co2mol .lt. 0.d0) WRITE(NHSTRY, $\left.{ }^{*}\right)$ ' WRITE: CO2MOL $=0$ (411) '

if (ch4mol .lt. $0 . \mathrm{d} 0$ ) $\mathrm{ch} 4 \mathrm{~mol}=0 . \mathrm{d} 0$

if (ch4mol .lt. 0.d0) WRITE(NHSTRY,*) 'WRITE: CH4MOL $=0$ (413) '

if (c2h4mol .lt. 0.d0) $\mathrm{c} 2 \mathrm{~h} 4 \mathrm{~mol}=0 . \mathrm{d} 0$

if (c2h4mol .lt. 0.d0) WRITE(NHSTRY,*) 'WRITE: CH24MOL $=0$ (415) '

if $(\mathrm{c} 2 \mathrm{~h} 2 \mathrm{~mol}$.lt. $0 . \mathrm{d} 0) \mathrm{c} 2 \mathrm{~h} 2 \mathrm{~mol}=0 . \mathrm{d} 0$

if (c2h2mol .lt. 0.d0) WRITE(NHSTRY, $\left.{ }^{*}\right)$ WRITE: C2H2MOL $=0$ (415) '

if (c2h6mol .lt. $0 . \mathrm{d} 0) \mathrm{c} 2 \mathrm{~h} 6 \mathrm{~mol}=0 . \mathrm{d} 0$

if (c2h6mol .lt. 0.d0) WRITE(NHSTRY,*) 'WRITE: C2H6MOL = 0 (417) '

C if (c6h6mol .lt. 0.d0) $\mathrm{c} 6 \mathrm{~h} 6 \mathrm{~mol}=0 . \mathrm{d} 0$

C if (c6h6mol .lt. 0.d0) WRITE(NHSTRY,*) 'WRITE: C6H6MOL $=0$ (419) '

if (TARmol .lt. 0.d0) TARmol $=0 . d 0$

if (TARmol .lt. 0.d0) WRITE(NHSTRY,*) 'WRITE: TARMOL $=0$ (421) '

WRITE(NHSTRY,998)H2MOL,COMOL,CO2MOL,CH4MOL,C2H4MOL, 1 C2H6MOL,TARMOL

998 FORMAT $/$, , GASIF. PRODUCTS',

1 ' MOLES ',$/$, ' H2 ',G12.5,' CO ',G12.5,

2 ' $\mathrm{CO} 2$ ',G12.5,,' $\mathrm{CH} 4$ ',G12.5,' C2H4 ',

$3 \quad \mathrm{G} 12.5, \mathrm{C}^{\prime} \mathrm{C} 26^{\prime}, \mathrm{G} 12.5, \mathrm{G} 12.5$, ,

4 ' TAR ',G12.5)

C

C

C DETERMINE THE AMOUNT OF STEAM FED TO GASIFIER

STM $=\operatorname{SIN}(\mathrm{L} 1+\mathrm{NH} 2 \mathrm{O})$ 


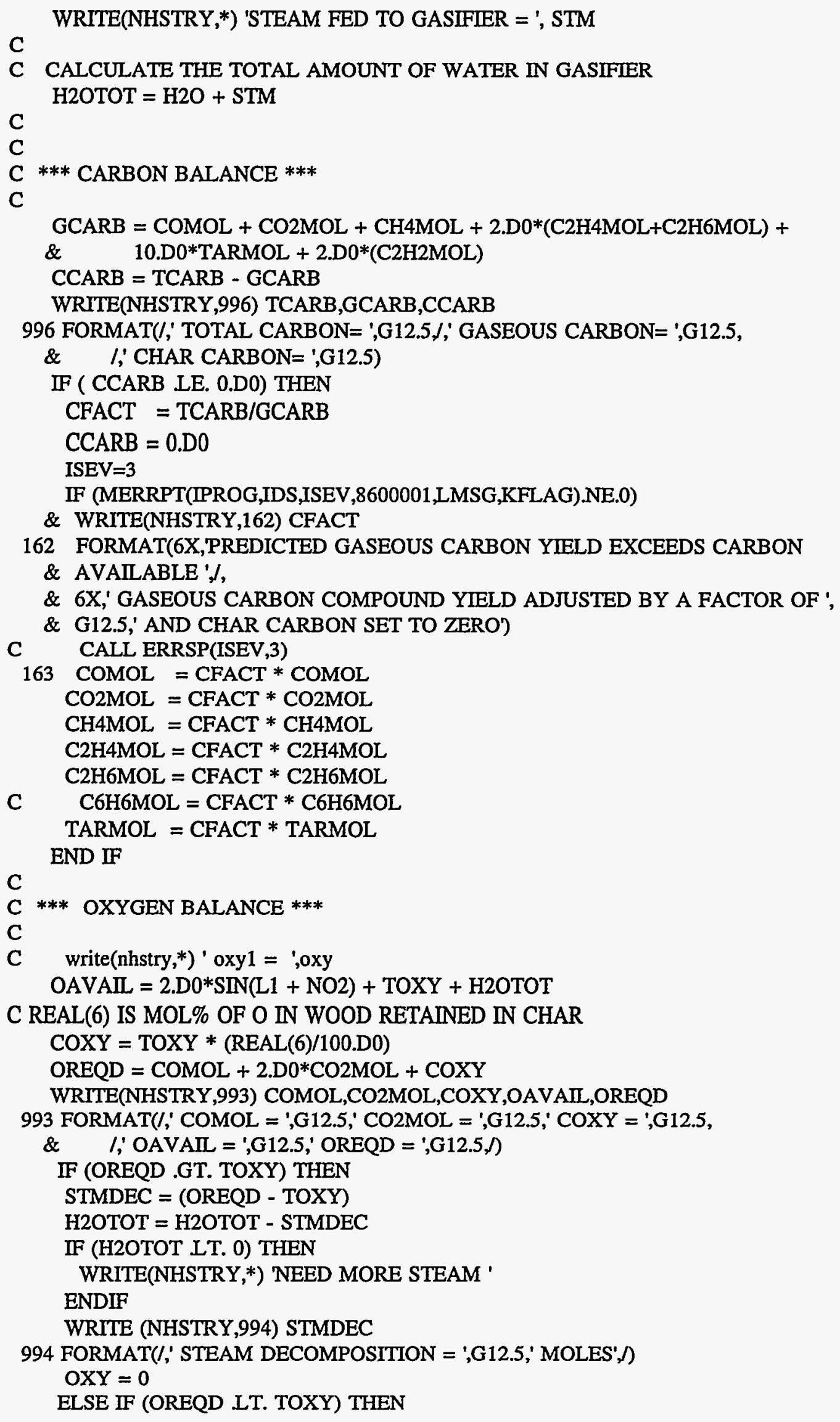




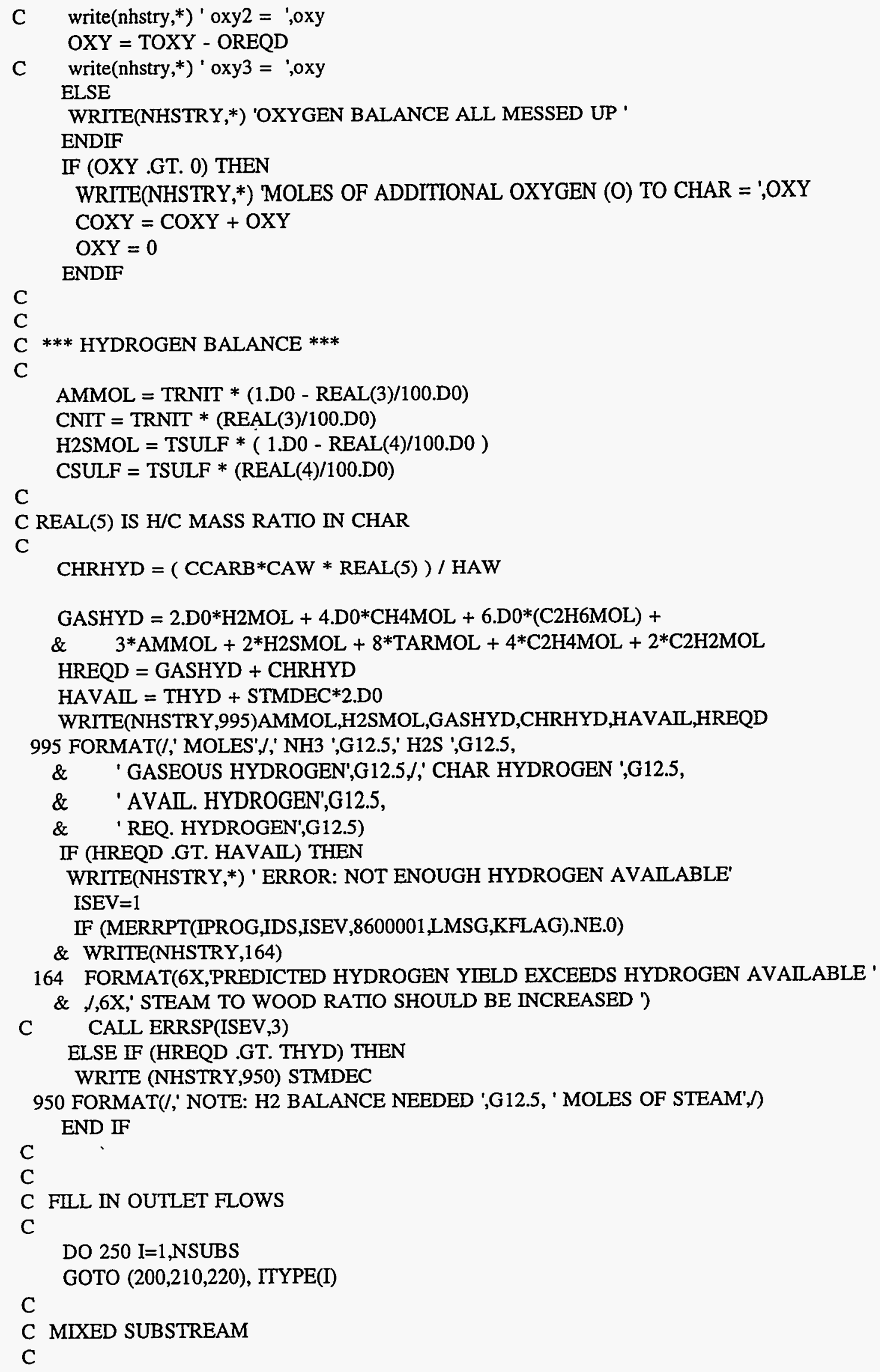




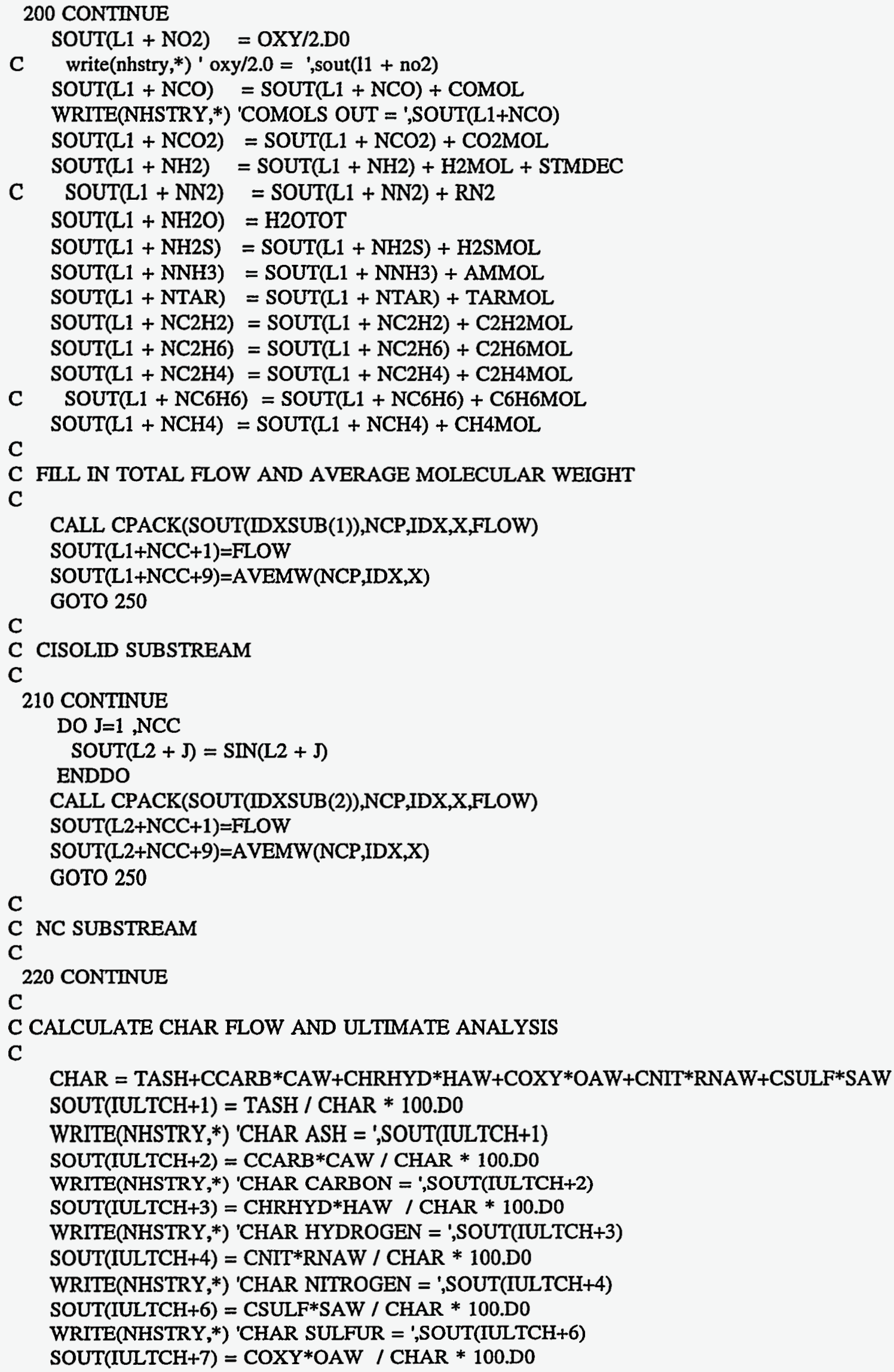


C

WRITE(NHSTRY,*) 'CHAR OXYGEN = ',SOUT(IULTCH+7)

SOUT(L3 + NWOOD $)=1 . D-10$

SOUT $(\mathrm{L} 3+\mathrm{NASH})=1 . \mathrm{D}-10$

SOUT $($ L3 + NCHAR $)=$ SOUT $($ L3 + NCHAR $)+$ CHAR

TOTNC $=0 . \mathrm{DO}$

DO $230 \mathrm{~J}=1$, NNCC

TOTNC $=$ TOTNC + SOUT $(L 3+J)$

230 CONTINUE

SOUT $(\mathrm{L} 3+\mathrm{NNCC}+1)=$ TOTNC

250 CONTINUE

C

C

C ADD UP INLET ENTHALPY

C

CALL TOTENT(SIN,NSUBS,IDXSUB,ITYPE,ENTHIN)

C

C FIND OUTLET STREAM ENTHALPY (TP FLASH)

C

C GUESS $=1.0$

C if (SOUT(1) .lt. 0.d0) $\operatorname{SOUT}(1)=0 . d 0$

C WRITE(NHSTRY,*) ' SOUT(O2)= ',SOUT(L1+NO2)

C WRITE(NHSTRY,*) 'SOUT AND POUT WRITES'

C DO J $=1, \mathrm{NCC}$

C WRITE(NHSTRY,*) SOUT(J)

C ENDDO

C WRITE(NHSTRY,*) POUT

CALL FLASH(SOUT,NSUBS,IDXSUB,ITYPE,NBOPST,2,2,1,30,1.D-4,

\& TOUT,POUT,GUESS,LMSG,LPMSG,IRESTR,2,RETN,IRETN,LCFLAG)

CALL TOTENT(SOUT,NSUBS,IDXSUB,ITYPE,ENTOUT)

C

C CALCULATE DUTY AND RETURN

$\mathrm{C}$

$\mathrm{Q}=\mathrm{ENTHIN}-\mathrm{ENTOUT}$

IF (LMSG.GE.4) WRITE(NHSTRY,300) ENTHIN,ENTOUT,Q

300 FORMAT(6X,'HIN =',E13.5,' HOUT =',E13.5,' Q =',E13.5)

RETURN

$\mathrm{C}$

C TERMINAL ERROR SECTION

C

$820 \mathrm{ISEV}=0$

IF (MERRPT(IPROG,IDS,ISEV,8600000,LMSG,KFLAG).EQ.0) GOTO 840

WRITE(NHSTRY,825)

825 FORMAT(6X,TMPROPER STREAM STRUCTURE.',/,6X,'STREAM STRUCTURE ',

1 'MUST BE MIXED + CISOLID + NC, IN THAT ORDER.')

C 830 CALL ERRSP(ISEV,3)

840 RETURN

END 
Appendix B: $\quad$ Economic Analysis Cost Sheets 


\section{General Equipment SIzes and Cosis}

\section{Scheme 1}

Capltal investment and operating costs at bottom of spreadsheet

\section{Pumps and Comprossors}

\section{WATPUMP}

\begin{tabular}{|c|c|c|c|c|c|c|c|c|c|c|c|c|}
\hline $\begin{array}{l}\text { Wood feed } \\
\text { bone dry tpd }\end{array}$ & $\begin{array}{l}\text { Wood feed } \\
\text { dried lb/hr }\end{array}$ & $\begin{array}{l}\text { H2 produced } \\
\text { scfd }\end{array}$ & $\begin{array}{l}\text { power } \\
\text { hp }\end{array}$ & & $\begin{array}{l}\text { flowrate } \\
\mathrm{ft} 3 / \mathrm{hr}\end{array}$ & & $\begin{array}{l}\text { flowrate } \\
\text { gal } / \mathrm{m} / \mathrm{n}\end{array}$ & & $\begin{array}{l}\text { delta P } \\
\text { psi }\end{array}$ & & $\begin{array}{l}\text { cost } \\
1994 \$\end{array}$ & \\
\hline 0.01068 & 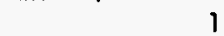 & $1 \quad 271$ & & 0.001 & & 0.012 & & 0.00 & & 333 & & \\
\hline 30 & 2,809 & 762,584 & & 2.763 & & 33.7 & & 4.21 & & 333 & & $\$ 2,900$ \\
\hline 300 & 28,090 & $7,625,843$ & & 27.633 & & 337.4 & & 42.06 & & 333 & & $\$ 8,100$ \\
\hline 1000 & 93,633 & $25,419,476$ & & 92.111 & & 1124.5 & & 140.20 & & 333 & & $\$ 14,800$ \\
\hline \multicolumn{13}{|c|}{ B5 (syncompr wator pump) } \\
\hline $\begin{array}{l}\text { Wood feed } \\
\text { bone dry fpd }\end{array}$ & $\begin{array}{l}\text { Wood feed } \\
\text { dried lb/hr }\end{array}$ & $\begin{array}{l}\text { H2 produced } \\
\text { scfd }\end{array}$ & $\begin{array}{l}\text { power } \\
\text { hp }\end{array}$ & & $\begin{array}{l}\text { flowrate } \\
\mathrm{ft} 3 / \mathrm{hr}\end{array}$ & & $\begin{array}{l}\text { flowrate } \\
\text { gal } / \mathrm{mln}\end{array}$ & & $\begin{array}{l}\text { delta P } \\
\text { psl }\end{array}$ & & $\begin{array}{l}\text { cost } \\
1994 \$\end{array}$ & \\
\hline 0.01068 & (1) & $1 \quad 271$ & & 0.001 & & 0.011 & & 0.00 & & 510 & & \\
\hline 30 & 2,809 & 762,584 & & 4.018 & & 32.0 & & 3.99 & & 510 & & $\$ 3,240$ \\
\hline 300 & 28,090 & $7,625,843$ & & 40.180 & & 320.3 & & 39.93 & & 510 & & $\$ 9,720$ \\
\hline 1000 & 93,633 & $25,419,476$ & & 133.933 & & 1067.6 & & 133.10 & & 510 & & $\$ 25,160$ \\
\hline \multicolumn{13}{|l|}{ B3 (ifcool wator pump) } \\
\hline $\begin{array}{l}\text { Wood feed } \\
\text { bone dry tpd }\end{array}$ & $\begin{array}{l}\text { Wood feed } \\
\text { dried lb/hr }\end{array}$ & $\begin{array}{l}\text { H2 produced } \\
\text { scfd }\end{array}$ & $\begin{array}{l}\text { power } \\
\text { hp }\end{array}$ & & $\begin{array}{l}\text { flowrate } \\
\mathrm{ft} 3 / \mathrm{hr}\end{array}$ & & $\begin{array}{l}\text { flowrate } \\
\text { gal } / \mathrm{mln}\end{array}$ & & $\begin{array}{l}\text { delta P } \\
\text { psi }\end{array}$ & & $\begin{array}{l}\text { cost } \\
1994 \$\end{array}$ & \\
\hline 0.01068 & (1) & 1271 & & 0.001 & & 0.006 & & 0.00 & & 485.304 & & \\
\hline 30 & 2,809 & 762,584 & & 2.004 & & 16.8 & & 2.09 & & 485.304 & & $\$ 2590$ \\
\hline 300 & 28,090 & $7,625,843$ & & 20.045 & & 167.9 & & 20.93 & & 485.304 & & $\$ 6,480$ \\
\hline 1000 & 93,633 & $25,419,476$ & & 66.816 & & 559.7 & & 69.78 & & 485.304 & & $\$ 12,580$ \\
\hline \multicolumn{13}{|c|}{ B7 (psacool water pump) } \\
\hline $\begin{array}{l}\text { Wood feed } \\
\text { bone dry tpd }\end{array}$ & $\begin{array}{l}\text { Wood feed } \\
\text { drled lb/hr }\end{array}$ & $\begin{array}{l}\text { H2 produced } \\
\text { scfd }\end{array}$ & $\begin{array}{l}\text { power } \\
\text { hp }\end{array}$ & & $\begin{array}{l}\text { flowrate } \\
\mathrm{ft} 3 / \mathrm{hr}\end{array}$ & & $\begin{array}{l}\text { flowrate } \\
\text { gal/min }\end{array}$ & & $\begin{array}{l}\text { delta } P \\
\text { psi }\end{array}$ & & $\begin{array}{l}\text { cost } \\
1994 \$\end{array}$ & \\
\hline 0.01068 & (1) & $1 \quad 271$ & & 0.000 & & 0.016 & & 0.00 & & 85 & & \\
\hline 30 & 2,809 & 762.584 & & 1.076 & & 45.4 & & 5.67 & & 85 & & $\$ 1,800$ \\
\hline 300 & 28,090 & $7,625,843$ & & 10.758 & & 454.5 & & 56.66 & & 85 & & $\$ 3,200$ \\
\hline 1000 & 93,633 & $25,419,476$ & & 35.861 & & 1515.0 & & 188.88 & & 85 & 5 & $\$ 5,400$ \\
\hline
\end{tabular}




\section{B13 (stmgens water pump)}

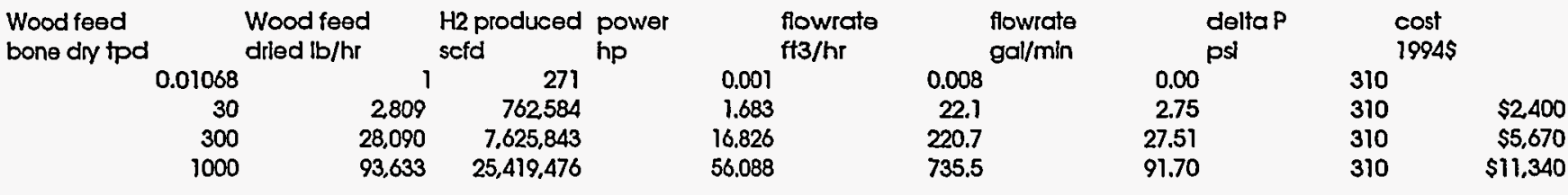

pumpl

Wood feed Wood feed H2 produced power bone dry tpd

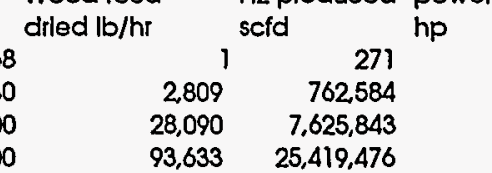

flowrate
$\mathrm{ft3/ \textrm {hr }}$
0.001
1.831
18.307
61.023

flowrate
gal/min
0.018
49.6
496.2
1653.8

\begin{tabular}{|c|c|c|}
\hline & & \\
\hline 0.00 & 150 & \\
\hline 6.19 & 150 & $\$ 2,000$ \\
\hline 61.86 & 150 & $\$ 4,200$ \\
\hline 206.19 & 150 & $\$ 7,500$ \\
\hline
\end{tabular}

pump2

\begin{tabular}{|c|c|c|c|}
\hline $\begin{array}{l}\text { Wood feed } \\
\text { bone dy tpd }\end{array}$ & $\begin{array}{l}\text { Wood feed } \\
\text { drled Ib/hr }\end{array}$ & $\begin{array}{l}\text { H2 produced } \\
\text { scfd }\end{array}$ & $\begin{array}{l}\text { power } \\
\text { hp }\end{array}$ \\
\hline & & $1 \quad 271$ & \\
\hline & 2,809 & 762,584 & \\
\hline & 28,090 & $7,625,843$ & \\
\hline & 93,633 & $25,419,476$ & \\
\hline \multicolumn{4}{|l|}{ pump3 } \\
\hline \multirow{5}{*}{ bone dry tpd } & $\begin{array}{l}\text { Wood feed } \\
\text { dried lib/hr }\end{array}$ & $\begin{array}{l}\text { H2 produced } \\
\text { scfd }\end{array}$ & $\begin{array}{l}\text { power } \\
\text { hp }\end{array}$ \\
\hline & & $1 \quad 271$ & \\
\hline & 2809 & 762,584 & \\
\hline & 28,090 & $7,625,843$ & \\
\hline & 93,633 & $25,419,476$ & \\
\hline
\end{tabular}

$\begin{array}{cc}\begin{array}{c}\text { flowrate } \\ \mathrm{ft3} / \mathrm{hr}\end{array} & \begin{array}{r}\text { flowrate } \\ \text { gal/min }\end{array} \\ 0.001 & 0.018 \\ 1.831 & 49.6 \\ 18.307 & 496.2 \\ 61.023 & 1653.8\end{array}$

deltaP $_{\text {psi }}$
$0.00^{\text {pi }}$
6.19
61.86
206.19

\begin{tabular}{ll}
\multicolumn{2}{c}{ cost } \\
$1994 \$$ & \\
150 & \\
150 & $\$ 2,000$ \\
150 & $\$ 4,200$ \\
150 & $\$ 7,500$
\end{tabular}

\section{pump4}

\begin{tabular}{|c|c|c|c|c|c|c|c|}
\hline $\begin{array}{l}\text { Wood feed } \\
\text { bone dry tod }\end{array}$ & $\begin{array}{l}\text { Wood feed } \\
\text { drled lb/hr }\end{array}$ & $\begin{array}{l}\text { H2 produced } \\
\text { scfd }\end{array}$ & $\begin{array}{l}\text { power } \\
\text { hp }\end{array}$ & $\begin{array}{l}\text { flowrate } \\
\mathrm{ft} / \mathrm{hr}\end{array}$ & & & \\
\hline 0.01068 & (a) & 271 & $2.49 E-05$ & 0.001 & 0.00 & 85 & \\
\hline 30 & 2809 & 762,584 & 0.070 & 3.3 & 0.42 & 85 & $\$ 1,500$ \\
\hline 300 & 28,090 & $7,625,843$ & 0.699 & 33.4 & 4.17 & 85 & $\$ 1,700$ \\
\hline 1000 & 93,633 & $25,419,476$ & 2.330 & 111.4 & 13.89 & 85 & $\$ 2,300$ \\
\hline
\end{tabular}


pump5

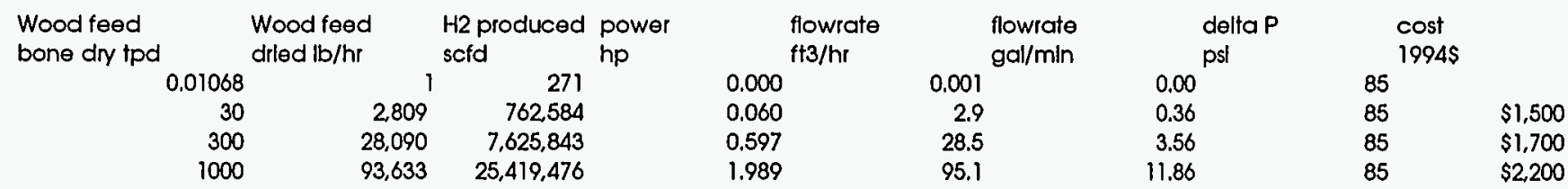

\section{OFFCOMPR}

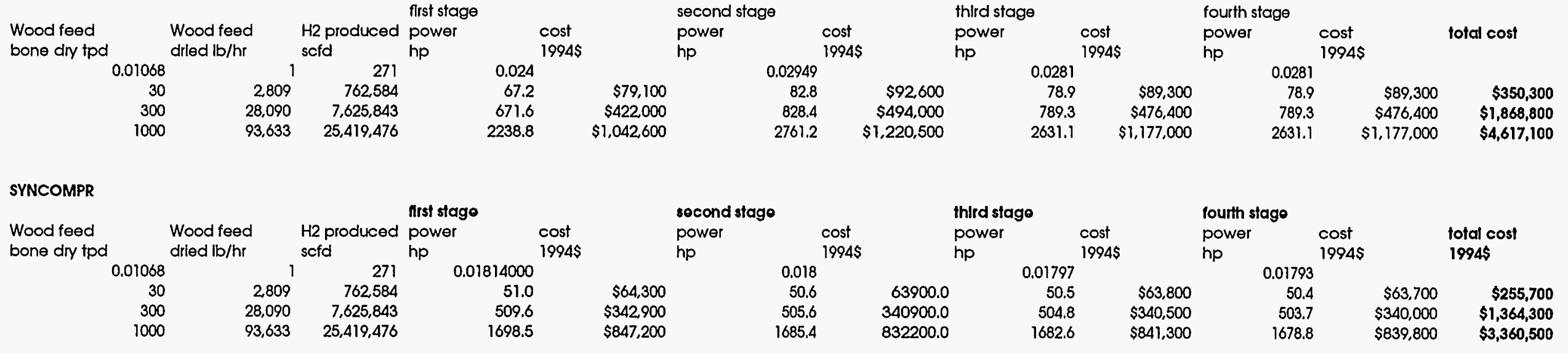




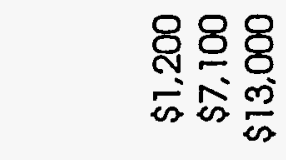

䐕 哭

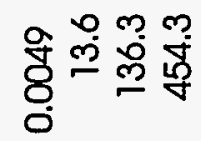

兽 함

可的可

겅

으음

竞

느는으는

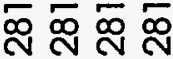

웅

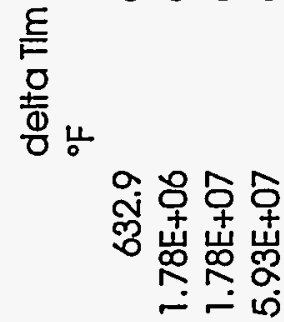

$\frac{7}{2} \frac{5}{7}$

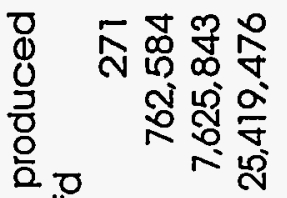

곰ํㅇ

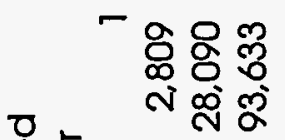

ㄴ ส

4 응

응

융요용

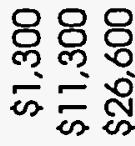

咅

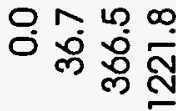

兽喜

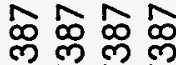

ก

ம்

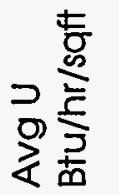

융 용요

o

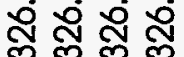

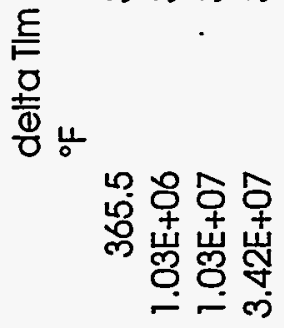

紊旁

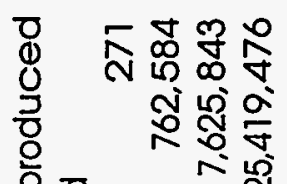

조응

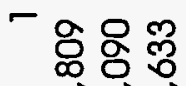

ง ผ

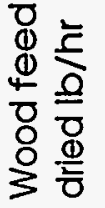

용용요
88.8

致合

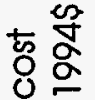

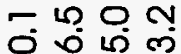

궁

$\checkmark \infty$

兽莀

œ

壱

초노ํํำ

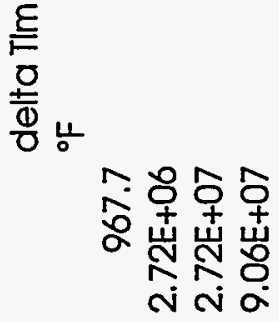

売志

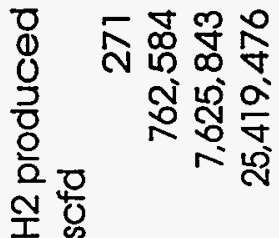

용

ง ฐิ๊

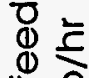

응

인

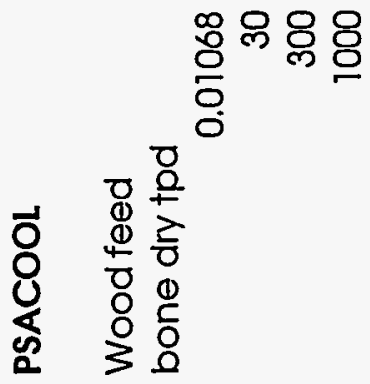




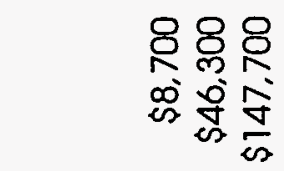

홍

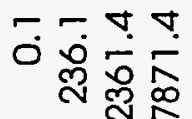

$\stackrel{0}{\frac{D}{0}}$

ลิธล์ิธ

g g g g

妾喜

的的的

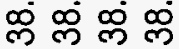

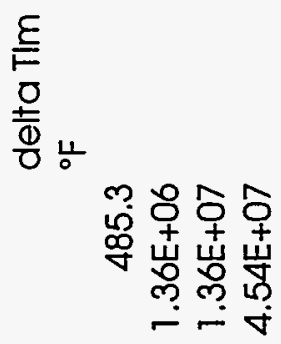

$\frac{7}{3} \sum_{0}^{\frac{\xi}{3}}$

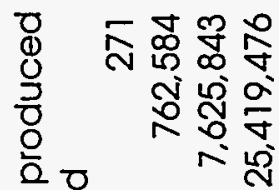

ํㅗ늉

-

ज哭

웡

음

$\stackrel{0}{\circ}$

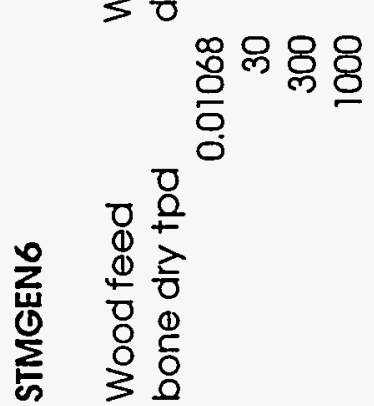

8웅워

营学

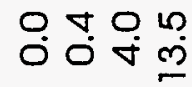

兽莺

人̂n

\%잉ㅇㅇㅇ

gig ga

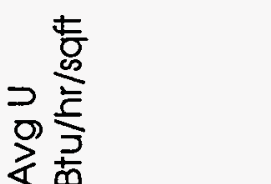

$\infty \infty$

ำ ำ

ㅇํㅇํำ

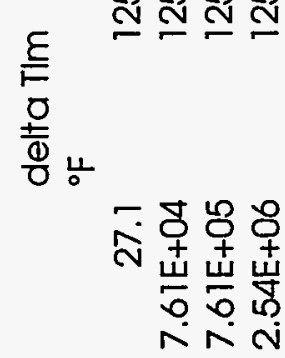

곻

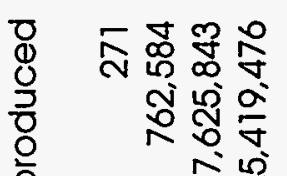

0

꿍ํํ

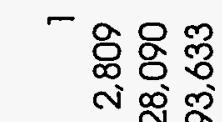

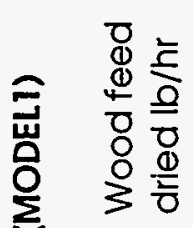

$3 \%$

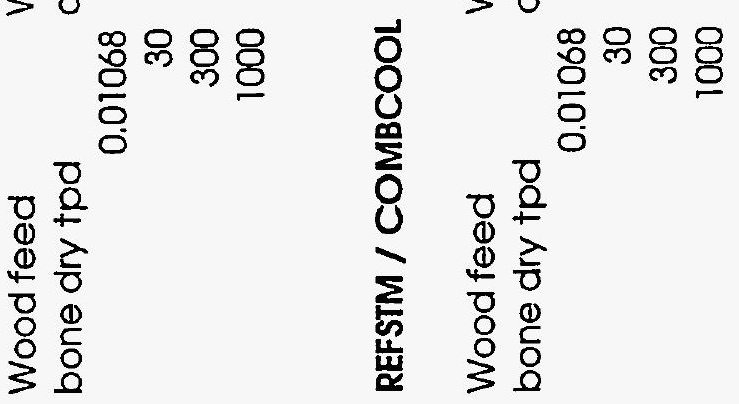

8.

苔密

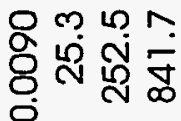

兽志

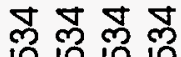

芚沾莒员

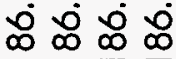

定竞
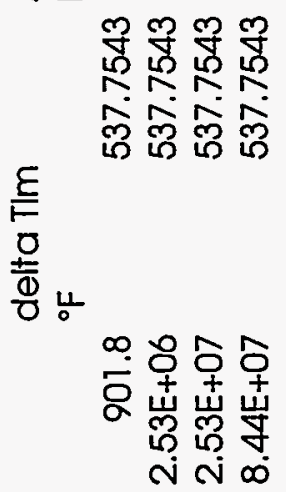

希站总

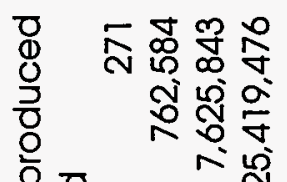

순융

- 용용

สู

흥

文

œ 용 8 용

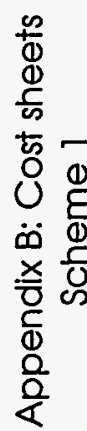




\section{SYNCOMPR INIERSTAGE COOLERS}

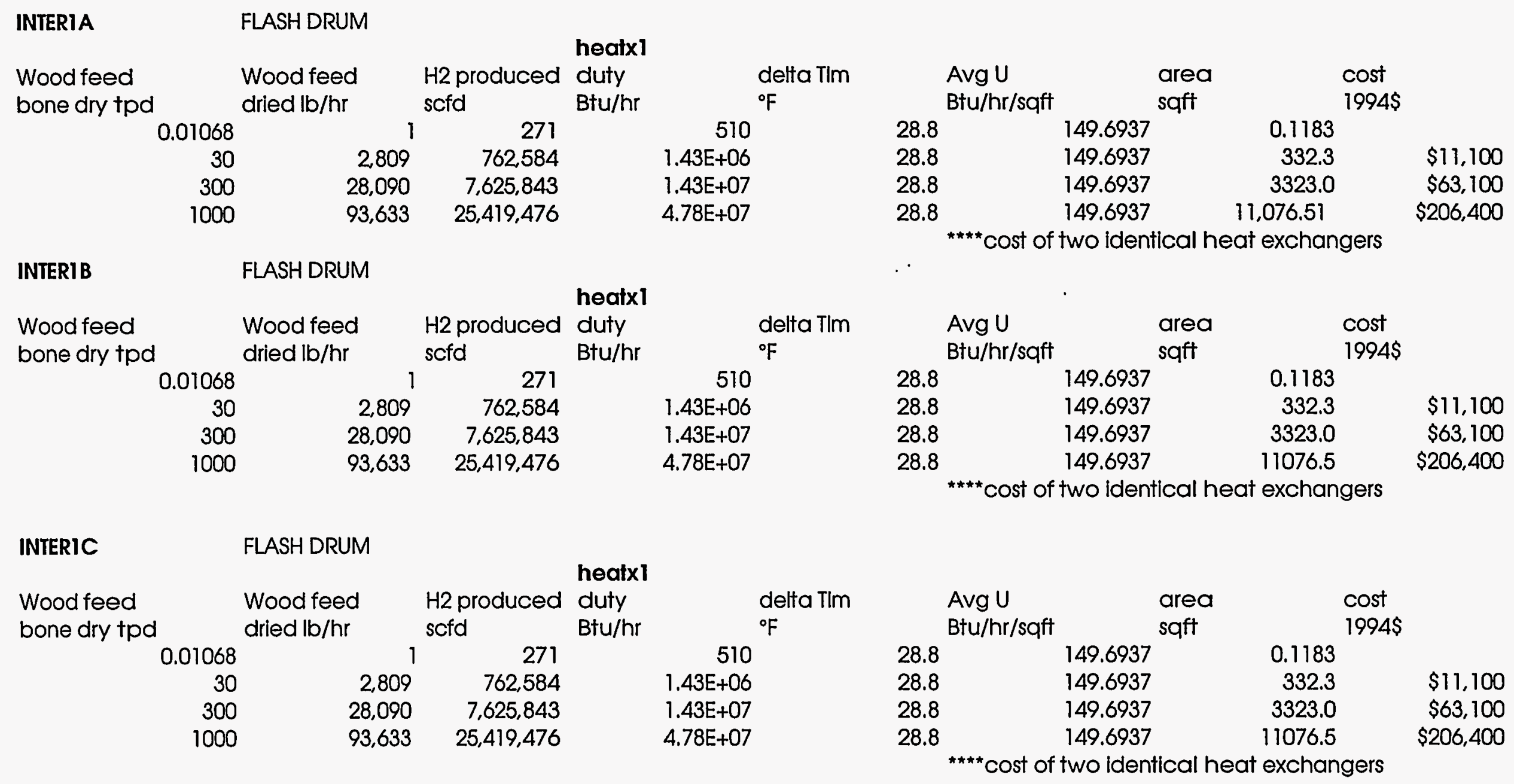




\section{OFFCOMPR INTERSTAGE COOLERS}

INTER2A

\begin{tabular}{|c|c|c|c|c|c|c|c|c|c|c|c|}
\hline $\begin{array}{l}\text { Wood feed } \\
\text { bone dry tpd }\end{array}$ & $\begin{array}{l}\text { Wood feed } \\
\text { dried } \mathrm{lb} / \mathrm{hr}\end{array}$ & $\begin{array}{l}\text { H2 produced } \\
\text { scfd }\end{array}$ & $\begin{array}{l}\text { duty } \\
\text { Btu/hr }\end{array}$ & & $\begin{array}{l}\text { delta TIm } \\
{ }^{\circ} \mathrm{F}\end{array}$ & $\begin{array}{l}\text { Avg U } \\
\text { Btu/hr/sqft }\end{array}$ & & $\begin{array}{l}\text { area } \\
\text { sqft }\end{array}$ & & $\begin{array}{l}\text { cost } \\
1994 \$\end{array}$ & \\
\hline 0.01068 & 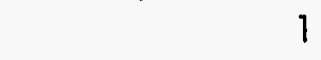 & 271 & & 71 & 75.9471 & & 19.3917 & & 0.0482 & & \\
\hline 30 & 2,809 & 762,584 & & $1.99 E+05$ & 75.9471 & & 19.3917 & & 135.4 & & $\$ 6,700$ \\
\hline 300 & 28,090 & $7,625,843$ & & $1.99 E+06$ & 75.9471 & & 19.3917 & & 1354.2 & & $\$ 28,900$ \\
\hline 1000 & 93,633 & $25,419,476$ & & $6.65 E+06$ & 75.9471 & & 19.3917 & & 4514.0 & & $\$ 84,400$ \\
\hline \multicolumn{12}{|l|}{ INTER2B } \\
\hline $\begin{array}{l}\text { Wood feed } \\
\text { bone dry tpd }\end{array}$ & $\begin{array}{l}\text { Wood feed } \\
\text { dried } \mathrm{lb} / \mathrm{hr}\end{array}$ & $\begin{array}{l}\text { H2 produced } \\
\text { scfd }\end{array}$ & $\begin{array}{l}\text { duty } \\
\text { Btu/hr }\end{array}$ & & $\begin{array}{l}\text { delta Tim } \\
{ }^{\circ} \mathrm{F}\end{array}$ & $\begin{array}{l}\text { Avg U } \\
\text { Btu/hr/sqft }\end{array}$ & & $\begin{array}{l}\text { area } \\
\text { sqfit }\end{array}$ & & $\begin{array}{l}\text { cost } \\
1994 \$\end{array}$ & \\
\hline 0.01068 & 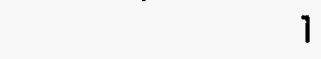 & 271 & & 60.3 & 58.4995 & & 14.4888 & & 0.0711 & & \\
\hline 30 & 2,809 & 762,584 & & $1.69 E+05$ & 58.4995 & & 14.4888 & & 199.8 & & $\$ 8,200$ \\
\hline 300 & 28,090 & $7,625,843$ & & $1.69 E+06$ & 58.4995 & & 14.4888 & & 1998.4 & & $\$ 40,000$ \\
\hline 1000 & 93,633 & $25,419,476$ & & $5.65 E+06$ & 58.4995 & & 14.4888 & & 6661.3 & & $\$ 124,300$ \\
\hline
\end{tabular}




\section{REACTORS}

\section{HTSHIFT}

SV $(1 / \mathrm{hr})=$

height/diameter

4000
2

height/did meter

Wood feed

bone dry tpd

\begin{tabular}{|c|c|c|c|c|c|}
\hline & $\begin{array}{l}\text { Wood feed } \\
\text { dried lb/hr }\end{array}$ & $\begin{array}{l}\text { H2 produced } \\
\text { scfd }\end{array}$ & $\begin{array}{l}\text { flowrate } \\
\text { acfh }{ }^{\star}\end{array}$ & $\begin{array}{l}\text { reactor volume } \\
\mathrm{ft} 3\end{array}$ & $\begin{array}{l}\text { diameter } \\
\mathrm{ft}\end{array}$ \\
\hline 01068 & 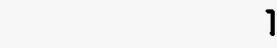 & 271 & 3.13 & 0.0008 & \\
\hline 30 & 2,809 & 762,584 & 8,804 & 2.20 & \\
\hline 300 & 28,090 & $7,625,843$ & 88,039 & 22.01 & \\
\hline 1000 & 93,633 & $25,419,476$ & 293,464 & 73.37 & \\
\hline
\end{tabular}

height
ft
0.08
1.12
2.41
3.60

pressure
psi
0.16
2.24
4.82
7.20

cost

$1994 \$$

SS316

504

$504 \quad \$ 6,700$

$504 \quad \$ 26,700$

$504 \quad \$ 56,200$

\section{LTSHIFT}

SV $(1 / \mathrm{hr})=$ height/diameter

4000

2

\section{Wood feed}

bone dry tpd

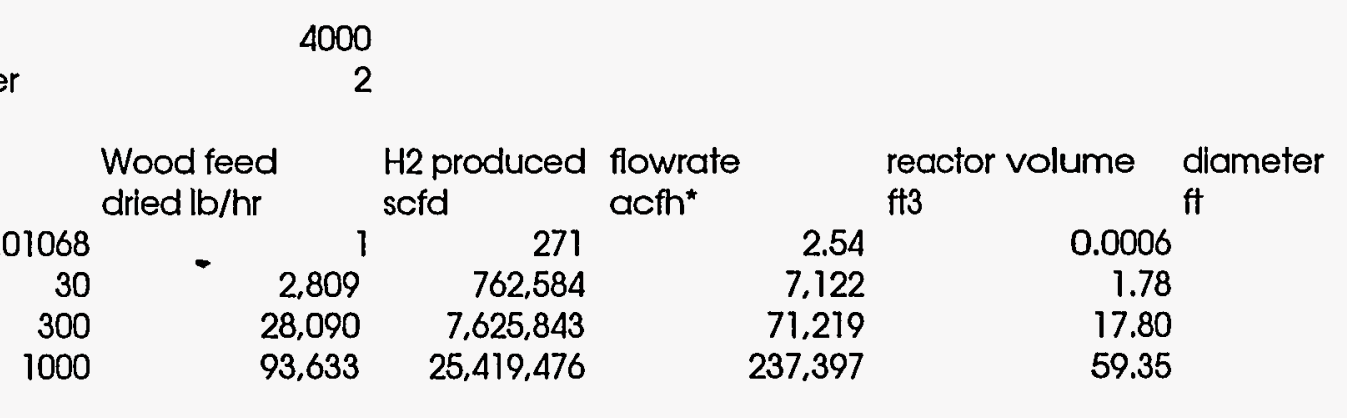

\begin{tabular}{|c|c|c|c|c|}
\hline $\begin{array}{l}\text { height } \\
\text { ft }\end{array}$ & $\begin{array}{l}\text { pressure } \\
\text { psi }\end{array}$ & & $\begin{array}{l}\text { cost } \\
1994 \$ \\
\text { SS316 }\end{array}$ & \\
\hline 0.07 & 0.15 & 427 & & \\
\hline 1.04 & 2.09 & 427 & & $\$ 5,900$ \\
\hline 2.25 & 4.49 & 427 & & $\$ 23,500$ \\
\hline 3.36 & 6.71 & 427 & & $\$ 49,400$ \\
\hline
\end{tabular}

${ }^{\star}$ acfh = actual cublc feet per hour

\section{PRIMARY REFORMER}

\begin{tabular}{|c|c|c|c|c|}
\hline $\begin{array}{l}\text { Wood feed } \\
\text { bone dry tpd }\end{array}$ & $\begin{array}{l}\text { Wood feed } \\
\text { dried lb/hr }\end{array}$ & $\begin{array}{l}\text { H2 produced } \\
\text { scfd }\end{array}$ & $\begin{array}{l}\text { Heat duty } \\
\text { MMBtu/hr }\end{array}$ & $\begin{array}{l}\text { Chem Cost } \\
1994 \$\end{array}$ \\
\hline 0.01068 & 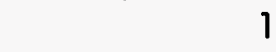 & 271 & 5.56E-04 & \\
\hline 30 & 2,809 & 762,584 & 1.562 & $\$ 53,6$ \\
\hline 300 & 28,090 & $7,625,843$ & 15.620 & $\$ 328,6$ \\
\hline 1000 & 93,633 & $25,419,476$ & 52.067 & $\$ 878,2$ \\
\hline
\end{tabular}

$\begin{array}{lr}\begin{array}{l}\text { P\&T, 3rd ed } \\ \text { 1994\$ }\end{array} & \begin{array}{l}\text { Chem Eng, Oct 10, } 1977 \\ 1994 \$\end{array} \\ & \\ \$ 329,500 & \$ 335,800 \\ \$ 915,200 & \$ 987,400\end{array}$

avg 


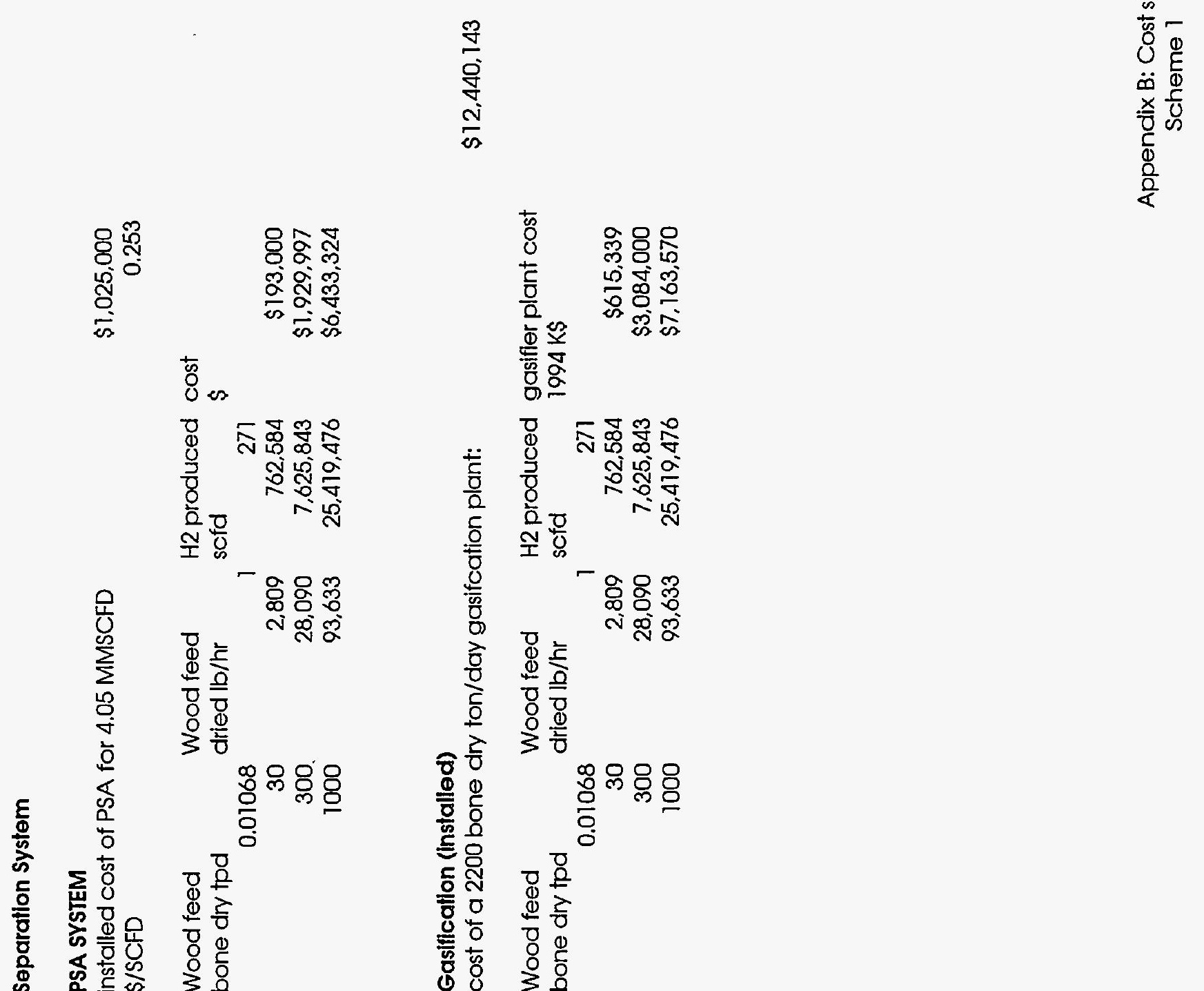




\section{Caplial Requirements}

$\begin{array}{lr}\text { Copltal expense } & \text { \% of purchased } \\ \text { instrumentation } & 18 \% \\ \text { piping } & 66 \% \\ \text { electrical } & 11 \% \\ \text { buildings } & 18 \% \\ \text { yard limprovements } & 10 \% \\ \text { service facilltes } & 70 \% \\ \text { land } & 6 \% \\ \text { engineering and construction } & 74 \% \\ \text { contingencles } & 42 \%\end{array}$

\begin{tabular}{|c|c|c|c|c|c|c|c|}
\hline $\begin{array}{l}\text { Equipment caphal } \\
\text { Wood feed } \\
\text { bone diy tpd }\end{array}$ & $\begin{array}{l}\text { Wood feed } \\
\text { drled lb/hr }\end{array}$ & $\begin{array}{l}\text { H2 produced } \\
\text { sefd }\end{array}$ & $\begin{array}{l}\text { Installed } \\
\text { ipltal }\end{array}$ & $\begin{array}{l}\text { Installation } \\
\text { cost }\end{array}$ & $\begin{array}{l}\text { other equipment } \\
\text { Installed }\end{array}$ & $\begin{array}{l}\text { total equipment cost } \\
\text { 1994S }\end{array}$ & $\begin{array}{l}\text { fotal unistalled } \\
\text { capltal }\end{array}$ \\
\hline 30 & 2809 & 762,584 & $\$ 765,130$ & $\$ 359,611$ & $\$ 808,339$ & $\$ 1,933,080$ & $\$ 1,315,020$ \\
\hline $\begin{array}{r}300 \\
1000\end{array}$ & $\begin{array}{l}28,090 \\
93,633\end{array}$ & $\begin{array}{r}7,625,843 \\
25,419,476\end{array}$ & $\begin{array}{r}\$ 4,048,370 \\
\$ 10,310,613\end{array}$ & $\begin{array}{l}\$ 1,902,734 \\
\$ 4,845,988\end{array}$ & $\begin{array}{r}\$ 5,013,997 \\
\$ 13,596,894\end{array}$ & $\begin{array}{l}\$ 10,965,101 \\
\$ 28,753,495\end{array}$ & $\begin{array}{r}\$ 7,459,252 \\
\$ 19,560,201\end{array}$ \\
\hline
\end{tabular}

Other fixed capital Investment

Wood feed Wood feed

$30^{\text {dried b/hr }}$ sefd instrumentation pliping

$\begin{array}{rrrrr}30 & 2,809 & 762,584 & \$ 236,704 & \$ 867,913 \\ 300 & 28,090 & 7,625,843 & \$ 1,342,665 & \$ 4,923,107\end{array}$

$\begin{array}{rrrrr}300 & 28,090 & 7,625,843 & \$ 1,342,665 & \$ 4,923,107 \\ 1000 & 93,633 & 25,419,476 & \$ 3,520,836 & \$ 12,909,733\end{array}$

electrical

$\$ 144,652$ bulldings $\$ 236,704$ yard

service facillitios land

$\$ 920,514$

$\$ 820,518 \quad \$ 1,342,665$

$\$ 745,925$

$\$ 5,221,477$

$\$ 78,901$
$\$ 447,555$
$\$ 1,773,612$

engineering contingencles total related fixed capital

$\$ 2,151,622 \quad \$ 3,520,836$

$\$ 1,956,020$

$\$ 13,692,14$

$\$ 1,173,612$

$\$ 973,115$
$\$ 5,519,847$

$\$ 552,308 \quad \$ 4,142,314$

$\$ 3,132,886 \quad \$ 23,496,645$

$\$ 14,474,549 \quad \$ 8,215,284 \quad \$ 61,614,633$

\section{Total fixed captial Investment}

Wood feed

$$
\text { Wood feed }
$$

H2 produced fixed capltal

$$
\text { dried lb/hr sefd }
$$

$\begin{array}{rrrr}30 & 2,809 & 762,584 & \$ 6,075,393 \\ 300 & 28,090 & 7,625,843 & \$ 34,461,747 \\ 1000 & 93,633 & 25,419,476 & \$ 90,368,129\end{array}$

Working capttal

Wood feod

$18 \%$ of the capttal expenditures estimated so far.

Wood feed

$$
\begin{aligned}
& \text { Wood feed H2 produced } \\
& \text { drled lb/hr sefd working capltal }
\end{aligned}
$$

$\begin{array}{rrrr}300 & 28,050 & 7,625,843 & \$ 6,203,114 \\ 1000 & 93,633 & 25,419,476 & \$ 16,266,263\end{array}$




\section{Operating costs}

\section{electricity cost}

on-line factor

\section{Elecfricity}

\section{Wood feed} bone dry tpd

0.01068
30
300
1000

\section{Wood feed} dried $\mathrm{lb} / \mathrm{hr}$
30

1000

\section{Waier}

for gasification

for reforming

for steam generation

BFW cost

\section{Wood feed} bone dry tpd

\begin{tabular}{rrr}
\multicolumn{2}{c}{ Wood feed } & \multicolumn{2}{c}{ H2 produced } \\
dried lb/hr & scfd \\
30 & 2,809 & 762,584 \\
300 & 28,090 & $7,625,843$ \\
1000 & 93,633 & $25,419,476$
\end{tabular}

$0.45 \mathrm{lb} / \mathrm{lb} \mathrm{bdw}$

$0.64 \mathrm{lb} / \mathrm{lb} \mathrm{bdw}$

$2.97 \mathrm{lb} / \mathrm{lb} \mathrm{bdw}$

$\$ 0.33 \$ / 1000$ liters

$0.05 \$ / \mathrm{kWh}$

0.9

H2 produced power requireme cost

scfd

2,809

28,090

93,633

$7,625,843$

271

hp

0.188
527.391
5273.907
17579.690

$\$ 155,044$

$\$ 1,550,440$

$\$ 5,168,134$

\section{for gasification 1000 liters/year 1000 liters/year}

for steam generatioltotal BFW cost 1000 lifers/year $\quad 1000$ liters/year $\$ / y r$

$\begin{array}{rr}2.01 & 2.86 \\ 20.09 & 28.63 \\ 66.95 & 95.43\end{array}$
13.29 132.89 442.97 18.16 181.61 605.35

\section{Operating costs of PSA}

\section{Wood feed} bone dry tpd

\section{Wood feed} dried $\mathrm{lb} / \mathrm{hr}$

30
300

1000

$\begin{array}{lll}\text { H2 produced op cost } & \text { cost } \\ \text { scfd } & \$ / 1000 \text { SCF } & \$ / y r \\ 762,584 & \$ 6.50 \\ 7,625,843 & \$ 6.50 \\ 25,419,476 & \$ 6.50\end{array}$

$\$ 4,957$

$\$ 49,568$

$\$ 165,227$ 


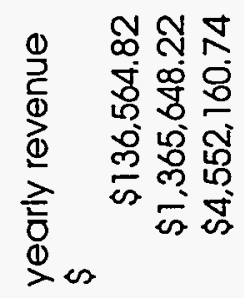

$\infty \infty \infty$ ผ

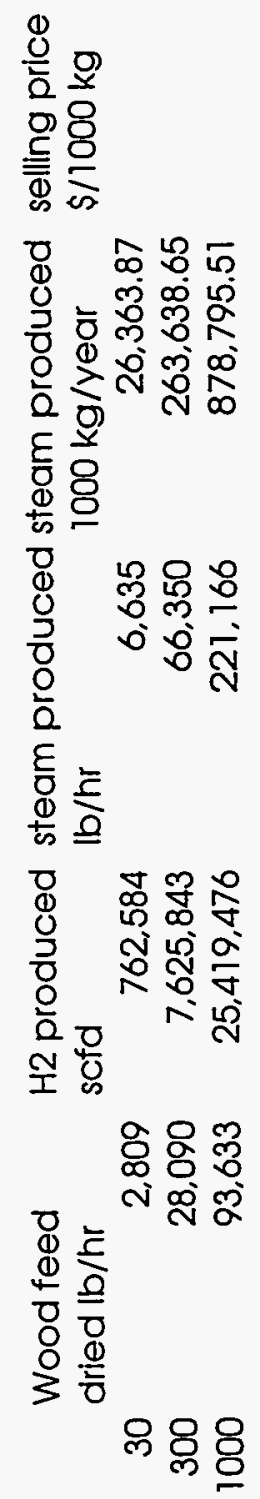

$\begin{array}{ll} & 0 \\ 0 & 0 \\ \Phi & 0 \\ \Phi & 2 \\ 0 & 0 \\ 0 & 0 \\ 0 & 0 \\ 3 & 0\end{array}$ 
Capital investment and operating costs at bottom of spreadsheet

change only those values in blue; others are calculated or imported from somewhere else.

Pumps and Comprossors

\section{WATPUMP}

\section{Wood feed}

bone dry tpd

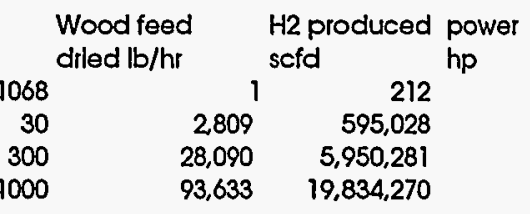

\section{B5 (syncompr wator pump)}

\begin{tabular}{|c|c|c|c|}
\hline $\begin{array}{l}\text { Wood feed } \\
\text { bone dry tpd }\end{array}$ & $\begin{array}{l}\text { Wood feed } \\
\text { drled lb/hr }\end{array}$ & $\begin{array}{l}\text { H2 produced } \\
\text { scfd }\end{array}$ & $\begin{array}{l}\text { power } \\
\text { hp }\end{array}$ \\
\hline 0.01068 & जल & $1 \quad 212$ & \\
\hline 30 & 2809 & 595,028 & \\
\hline 300 & 28,090 & $5,950,281$ & \\
\hline 1000 & 93,633 & $19,834,270$ & \\
\hline \multicolumn{4}{|l|}{ B3 (itcool water pump) } \\
\hline $\begin{array}{l}\text { Wood feed } \\
\text { bone dry tpd }\end{array}$ & $\begin{array}{l}\text { Wood feed } \\
\text { dried lb/hr }\end{array}$ & $\begin{array}{l}\text { H2 produced } \\
\text { scfd }\end{array}$ & $\begin{array}{l}\text { power } \\
\text { hp }\end{array}$ \\
\hline 0.01068 & & $1 \quad 212$ & \\
\hline 30 & 2,809 & 595,028 & \\
\hline 300 & 28,090 & $5,950,281$ & \\
\hline 1000 & 93,633 & $19,834,270$ & \\
\hline \multicolumn{4}{|c|}{ B7 (psacool wator pump) } \\
\hline $\begin{array}{l}\text { Wood feed } \\
\text { bone dry tpd }\end{array}$ & $\begin{array}{l}\text { Wood feed } \\
\text { drled } \mathrm{lb} / \mathrm{hr}\end{array}$ & $\begin{array}{l}\text { H2 produced } \\
\text { scfd }\end{array}$ & $\begin{array}{l}\text { power } \\
\text { hp }\end{array}$ \\
\hline 0.01068 & & $1 \quad 212$ & \\
\hline 30 & 2,809 & 595,028 & \\
\hline 300 & 28,090 & $5,950,281$ & \\
\hline 1000 & 93,633 & $19,834,270$ & \\
\hline
\end{tabular}

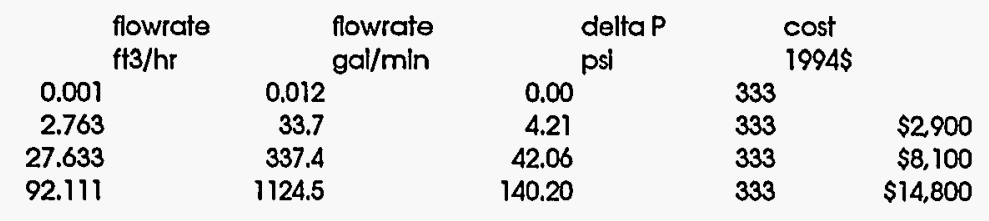

\begin{tabular}{rrrrrr} 
flowrate & flowrate & deltaP & \multicolumn{2}{c}{ cost } & \\
$\mathrm{f}+3 / \mathrm{hr}$ & gal/min & psl & \multicolumn{2}{c}{$1994 \$$} & \\
0.001 & 0.011 & 0.00 & 510 & \\
4.018 & 32.0 & 3.99 & 510 & $\$ 3,240$ \\
40.180 & 320.3 & 39.93 & 510 & $\$ 9.720$ \\
133.933 & 1067.6 & 133.10 & 510 & $\$ 25,160$
\end{tabular}

\begin{tabular}{rccrr} 
flowrate & \multicolumn{1}{c}{$\begin{array}{c}\text { flowrate } \\
\text { gal/min }\end{array}$} & \multicolumn{2}{c}{ delta P } & \multicolumn{2}{c}{$\begin{array}{c}\text { cost } \\
\text { psl }\end{array}$} \\
0.001 & 0.006 & 0.00 & 485.304 & \\
2.004 & 16.8 & 2.09 & 485.304 & $\$ 2,590$ \\
20.045 & 167.9 & 20.93 & 485.304 & $\$ 6,480$ \\
66.816 & 559.7 & 69.78 & 485.304 & $\$ 12,580$
\end{tabular}

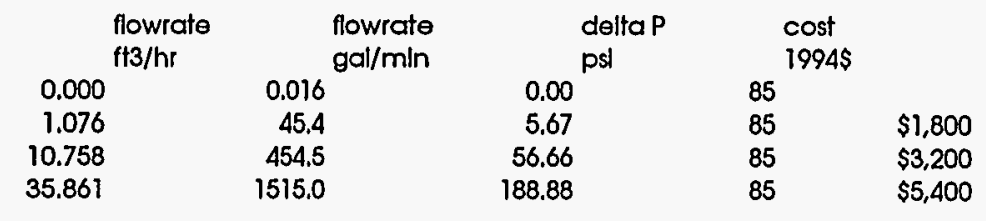




\section{3 (simgonb walor pump)}

\begin{tabular}{|c|c|c|c|c|c|c|c|c|c|c|c|c|}
\hline $\begin{array}{l}\text { ood feed } \\
\text { נne dry tpd }\end{array}$ & $\begin{array}{l}\text { Wood feed } \\
\text { dried lb/hr }\end{array}$ & $\begin{array}{l}\text { H2 produced } \\
\text { scfd }\end{array}$ & $\begin{array}{l}\text { power } \\
\text { hp }\end{array}$ & & $\begin{array}{l}\text { flowrate } \\
\mathrm{ft} 3 / \mathrm{hr}\end{array}$ & & $\begin{array}{l}\text { flowrate } \\
\text { gal/mln }\end{array}$ & & $\begin{array}{l}\text { delta P } \\
\text { psil }\end{array}$ & & $\begin{array}{l}\text { cost } \\
1994 \$\end{array}$ & \\
\hline 0.01068 & 3 & 212 & & 0.001 & & 0.008 & & 0.00 & & 310 & & \\
\hline 30 & 2.809 & 595,028 & & 1.683 & & 22.1 & & 2.75 & & 310 & & $\$ 2,400$ \\
\hline 300 & 28,090 & $5,950,281$ & & 16.826 & & 220.7 & & 27.51 & & 310 & & $\$ 5,670$ \\
\hline 1000 & 93,633 & $19,834,270$ & & 56.088 & & 735.5 & & 91.70 & & 310 & & $\$ 11,340$ \\
\hline \multicolumn{13}{|l|}{ Impl } \\
\hline $\begin{array}{l}\text { ood feed } \\
\text { sne dy tpd }\end{array}$ & $\begin{array}{l}\text { Wood feed } \\
\text { dried lb/hr }\end{array}$ & $\begin{array}{l}\text { H2 produced } \\
\text { scfd }\end{array}$ & $\begin{array}{l}\text { power } \\
\text { hp }\end{array}$ & & $\begin{array}{l}\text { flowrate } \\
\mathrm{ft} 3 / \mathrm{hr}\end{array}$ & & $\begin{array}{l}\text { flowrate } \\
\text { gal } / \mathrm{m} \ln \end{array}$ & & $\begin{array}{l}\text { delta P } \\
\text { psi }\end{array}$ & & $\begin{array}{l}\text { cost } \\
1994 \$\end{array}$ & \\
\hline 0.01068 & 3 & 212 & & 0.001 & & 0.018 & & 0.00 & & 150 & & \\
\hline 30 & 2,809 & 595,028 & & 1.831 & & 49.6 & & 6.19 & & 150 & & $\$ 2,000$ \\
\hline 300 & 28,090 & $5,950,281$ & & 18.307 & & 496.2 & & 61.86 & & 150 & & $\$ 4,200$ \\
\hline 1000 & 93,633 & $19,834,270$ & & 61.023 & & 1653.8 & & 206.19 & & 150 & & $\$ 7,500$ \\
\hline \multicolumn{13}{|l|}{ smp2 } \\
\hline $\begin{array}{l}\text { lood feed } \\
\text { one dry tpd }\end{array}$ & $\begin{array}{l}\text { Wood feed } \\
\text { dried lb/hr }\end{array}$ & $\begin{array}{l}\text { H2 produced } \\
\text { scfd }\end{array}$ & $\begin{array}{l}\text { power } \\
\text { hp }\end{array}$ & & $\begin{array}{l}\text { flowrate } \\
\mathrm{f}+3 / \mathrm{hr}\end{array}$ & & $\begin{array}{l}\text { flowrate } \\
\text { gal } / \mathrm{min}\end{array}$ & & $\begin{array}{l}\text { delta P } \\
\text { psl }\end{array}$ & & $\begin{array}{l}\text { cost } \\
1994 \$\end{array}$ & \\
\hline 0.01068 & 3 & 212 & & 0.001 & & 0.018 & & 0.00 & & 150 & & \\
\hline 30 & 2809 & 595,028 & & 1.831 & & 49.6 & & 6.19 & & 150 & & $\$ 2,000$ \\
\hline 300 & 28,090 & $5,950,281$ & & 18.307 & & 496.2 & & 61.86 & & 150 & & $\$ 4,200$ \\
\hline 1000 & 93,633 & $19,834,270$ & & 61.023 & & 1653.8 & & 206.19 & & 150 & & $\$ 7,500$ \\
\hline \multicolumn{13}{|l|}{ ump3 } \\
\hline $\begin{array}{l}\text { lood feed } \\
\text { one dry tpd }\end{array}$ & $\begin{array}{l}\text { Wood feed } \\
\text { dried lb/hr }\end{array}$ & $\begin{array}{l}\text { H2 produced } \\
\text { scfd }\end{array}$ & $\begin{array}{l}\text { power } \\
\text { hp }\end{array}$ & & $\begin{array}{l}\text { flowrate } \\
\mathrm{ft} / \mathrm{hr}\end{array}$ & & $\begin{array}{l}\text { flowrate } \\
\text { gal/min }\end{array}$ & & $\begin{array}{l}\text { delta P } \\
\text { psi }\end{array}$ & & $\begin{array}{l}\text { cost } \\
1994 \$\end{array}$ & \\
\hline 0.01068 & 3 & $1 \quad 212$ & & 0.001 & & 0.018 & & 0.00 & & 150 & & \\
\hline 30 & 2,809 & 595,028 & & 1.831 & & 49.6 & & 6.19 & & 150 & & $\$ 2,000$ \\
\hline 300 & 28,090 & $5,950,281$ & & 18.307 & & 496,2 & & 61.86 & & 150 & & $\$ 4,200$ \\
\hline 1000 & 93,633 & $19,834,270$ & & 61.023 & & 1653.8 & & 206.19 & & 150 & & $\$ 7,500$ \\
\hline \multicolumn{13}{|l|}{ ump4 } \\
\hline $\begin{array}{l}\text { Vood feed } \\
\text { one dry tpd }\end{array}$ & $\begin{array}{l}\text { Wood feed } \\
\text { dried lb/hr }\end{array}$ & $\begin{array}{l}\text { H2 produced } \\
\text { scfd }\end{array}$ & $\begin{array}{l}\text { power } \\
\text { hp }\end{array}$ & & $\begin{array}{l}\text { flowrate } \\
\mathrm{ft} 3 / \mathrm{hr}\end{array}$ & & $\begin{array}{l}\text { flowrate } \\
\text { gal/min }\end{array}$ & & $\begin{array}{l}\text { delta P } \\
\text { psl }\end{array}$ & & $\begin{array}{l}\text { cost } \\
1994 \$\end{array}$ & \\
\hline 0.01068 & 3 & $1 \quad 212$ & & $2.49 \mathrm{E}-05$ & & 0.001 & & 0.00 & & 85 & & \\
\hline 30 & 2,809 & 595,028 & & 0.070 & & 3.3 & & 0.42 & & 85 & & $\$ 1,500$ \\
\hline 300 & 28,090 & $5,950,281$ & & 0.699 & & 33.4 & & 4.17 & & 85 & & $\$ 1,700$ \\
\hline 1000 & 93,633 & $19,834,270$ & & 2.330 & & 111.4 & & 13.89 & & 85 & & $\$ 2,300$ \\
\hline
\end{tabular}


Wood feed bone dry tpd

\begin{tabular}{|c|c|c|}
\hline & $\begin{array}{l}\text { Wood feed } \\
\text { dried lb/hr }\end{array}$ & $\begin{array}{l}\text { H2 produced power } \\
\text { scfd hp }\end{array}$ \\
\hline .01068 & & 212 \\
\hline 30 & 2809 & 595,028 \\
\hline 300 & 28,090 & $5,950,281$ \\
\hline 1000 & 93,633 & $19,834,270$ \\
\hline
\end{tabular}

first stage

\begin{tabular}{lrrr} 
Wood feed & \multicolumn{2}{c}{ H2 produced power } \\
scfd & first stage \\
dried lb/hr & scf $^{2}$ & 212 \\
30 & 2809 & 595,028 \\
00 & 28,090 & $5,950,281$ \\
0 & 93,633 & $19,834,270$
\end{tabular}

cost
0.018
50.4
503.9
1679.8

$\$ 60,300$
$\$ 340,100$
$\$ 840,200$

second stage
power

cost
0.02213
62.2
621.6
2072.1

$\$ 70,600$
$\$ 398,100$
$\$ 987,700$

third stage

power cost

hp $0.02109{ }^{1994 \$}$

$\$ 68,100$
$\$ 384,000$
$\$ 948,800$

fourth stage
power cost $1994 \$$
hp $\quad 0.02109$

total cost

$\begin{array}{rr}592.4 & \$ 384,000 \\ 1974.7 & \$ 948,800\end{array}$

59.2
592.4
1974.7

$\$ 6,810$

$\$ 384,000$

$\$ 948,800$

$\$ 205,810$

$\$ 1,506,200$

$\$ 3,725,500$

\section{SYNCOMPR}

Wood feed
bone dry tpd

\begin{tabular}{|c|c|c|c|c|}
\hline & $\begin{array}{l}\text { Wood feed } \\
\text { drled lb/hr }\end{array}$ & $\begin{array}{l}\text { H2 produced } \\
\text { scfd }\end{array}$ & $\begin{array}{l}\text { filst stage } \\
\text { power } \\
\text { hp }\end{array}$ & \\
\hline 1.01068 & & 212 & & 0.0161 \\
\hline 30 & 2809 & 595,028 & & 45.2 \\
\hline 300 & 28,090 & $5,950,281$ & & 452.2 \\
\hline 1000 & 93,633 & $19,834,270$ & & 1507.5 \\
\hline
\end{tabular}

$\$ 55,000$
$\$ 313,500$
$\$ 774,600$

second stage

power

cost
$4^{1994 \$}$
44.9

third stage

power

cost
0.01596
44.8

cost

$\begin{array}{rr}448.9 & 55300.0 \\ 411800.0\end{array}$

$1496.3 \quad 770300.0$

448.3

1494.4

$\$ 774,600$

\begin{tabular}{lrrrr}
$\begin{array}{l}\text { louth stage } \\
\text { power }\end{array}$ & cost & \multicolumn{1}{l}{$\begin{array}{l}\text { lotal cost } \\
\text { ho }\end{array}$} & $\begin{array}{l}\text { l994\$ } \\
\text { hp }\end{array}$ & \multicolumn{2}{l}{$1994 \$$} \\
& 0.01593 & & & \\
& 44.7 & $\$ 55,100$ & $\$ 220,600$ \\
& 447.5 & $\$ 11,000$ & $\$ 947,800$ \\
& 1491.6 & $\$ 768,500$ & $\$ 3,082,900$
\end{tabular}


oat Exchangers and Heaters

\section{STMGEN}

lood feec

one dry tpc

Wood feed

drled lb/hr

$\begin{array}{ll}\mathrm{H} 2 \text { produced duty } \\ \text { scfd } & \text { Btu/hr }\end{array}$

delta TIm
of

Avg U

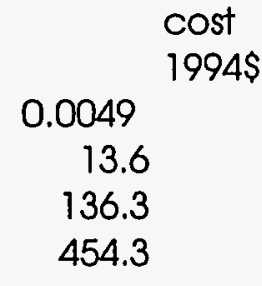

0.01068

30

300

$1_{2} 212$

632.9

679.2815

$\begin{array}{rr}2,809 & 595,028 \\ 28,090 & 5,950,281\end{array}$

$1.78 \mathrm{E}+06$
$1.78 \mathrm{E}+07$

93,633

$19,834,270$

679.2815

679.2815

area
192.0261
192.0261
192.0261
192.0261

$\$ 1,200$

$5.93 \mathrm{E}+07$

192.0261

$\$ 7,100$

$\$ 13,000$

COOL

lood feed one dry tpd

Woodfeed H2 produced duty drled $\mathrm{lb} / \mathrm{hr}$ scfd Btu/hr

\begin{tabular}{rr}
\multicolumn{2}{c}{ delta TIm } \\
${ }^{\circ} \mathrm{F}$ & \\
365.5 & 326.6936 \\
$1.03 \mathrm{E}+06$ & 326.6936 \\
$1.03 \mathrm{E}+07$ & 326.6936 \\
$3.42 \mathrm{E}+07$ & 326.6936
\end{tabular}

Avg $U$

Btu/hr/sqft

area
sqft
85.7387
85.7387
85.7387
85.7387

$\begin{aligned} &{ }^{c} \text { cost } \\ & 0.0 \\ & 36.7 \\ & 366.5 \\ & 1221.8\end{aligned}$

$\$ 1,300$

$2,809 \quad 595,028$

28,090

$5,950,281$

$3.42 \mathrm{E}+07$

85.7387

$\$ 11,300$

$\$ 26,600$

\section{SACOOL}

Jood feec one dry tpd

\begin{tabular}{|c|c|c|c|}
\hline & $\begin{array}{l}\text { Wood feed } \\
\text { dried } \mathrm{lb} / \mathrm{hr}\end{array}$ & $\begin{array}{l}\text { H2 produced } \\
\text { scfd }\end{array}$ & $\begin{array}{l}\text { duty } \\
\text { Btu/hr }\end{array}$ \\
\hline 0.01068 & 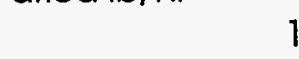 & 212 & 967.7 \\
\hline 30 & 2,809 & 595,028 & $2.72 E+06$ \\
\hline 300 & 28,090 & $5,950,281$ & $2.72 E+07$ \\
\hline 1000 & 93,633 & $19,834,270$ & $9.06 E+07$ \\
\hline
\end{tabular}

Avg U
Btu/hr/sqft
120
120
120
120

area
sqft
85
85
85
85

cost $1994 \$$

0.1

266.5

$\$ 9,300$

2665.0

$\$ 51,600$

8883.2

$\$ 167,800$ 


\section{STMGEN6}






\section{YNCOMPR INIERSTAGE COOLERS}

VTERIA

Vood feed sone dry tpd

FLASH DRUM

\begin{tabular}{|c|c|c|}
\hline & $\begin{array}{l}\text { Wood feed } \\
\text { dried Ib/hr }\end{array}$ & $\begin{array}{l}\text { H2 produced } \\
\text { scfd }\end{array}$ \\
\hline 0.01068 & 1 & 212 \\
\hline 30 & 2,809 & 595,028 \\
\hline 300 & 28,090 & $5,950,281$ \\
\hline 1000 & 93,633 & $19,834,270$ \\
\hline
\end{tabular}

FLASH DRUM

NTERIB

Vood feed sone dry tpd
0.01068

30

300

1000

NTERIC

Nood feed sone dry tpd

0.01068
30
300
1000

\section{FLASH DRUM}

heatxl

H2 produced duty

dried $\mathrm{lb} / \mathrm{hr}$ scfd Btu/hr

$\begin{array}{rr}1 & 212 \\ 2,809 & 595,028\end{array}$

$28,090 \quad 5,950,281$

$93,633 \quad 19,834,270$

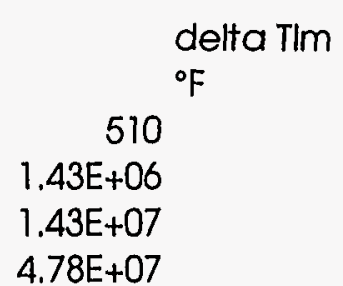

\section{heatx 1}

H2 produced duty

scfd Btu/hr

$\begin{array}{rrr}1 & 212 & 510 \\ 2,809 & 595,028 & 1.43 E+06 \\ 28,090 & 5,950,281 & 1.43 E+07 \\ 93,633 & 19,834,270 & 4.78 E+07\end{array}$

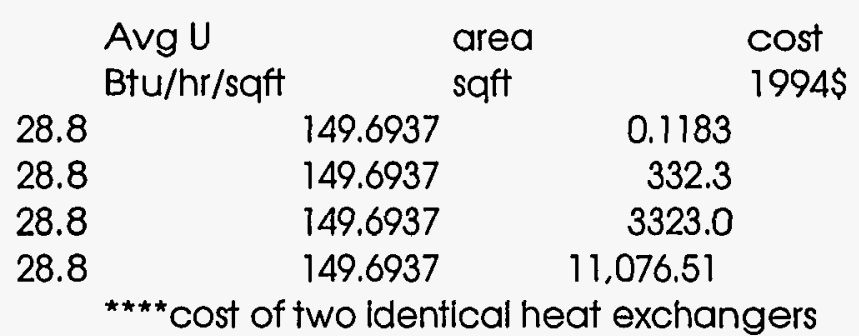

$\$ 11,100$

$\$ 63,100$

$\$ 206,400$

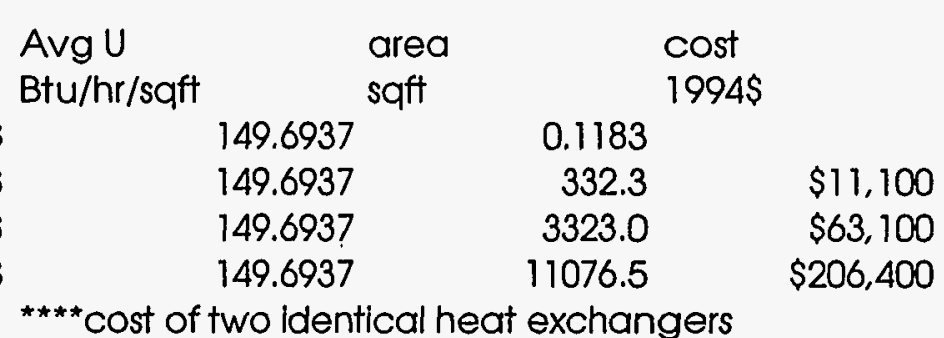

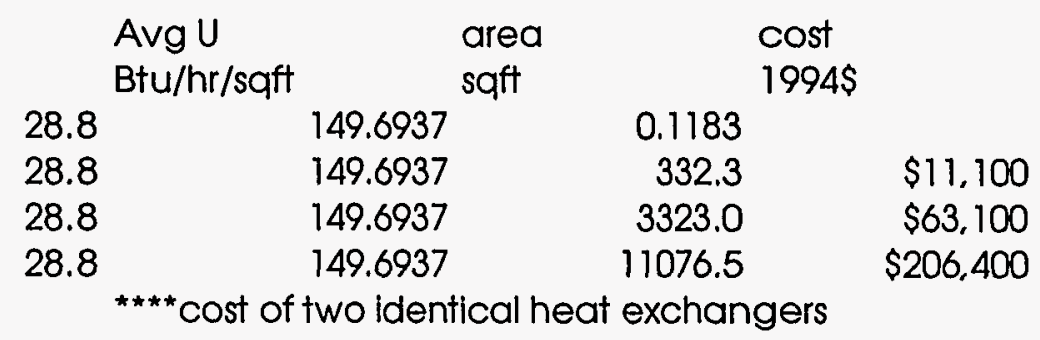

delta TIm
510
${ }^{\circ} \mathrm{F}$
$1.43 \mathrm{E}+06$
$1.43 \mathrm{E}+07$
$4.78 \mathrm{E}+07$




\section{OFFCOMPR INTERSTAGE COOLERS}

\section{INTER2A}

\begin{tabular}{|c|c|c|c|c|c|c|c|c|c|c|}
\hline $\begin{array}{l}\text { Wood feed } \\
\text { bone dry tpd }\end{array}$ & $\begin{array}{l}\text { Wood feed } \\
\text { dried } \mathrm{lb} / \mathrm{hr}\end{array}$ & $\begin{array}{ll}\text { H2 produced duty } \\
\text { scfd } & \text { Btu/hr }\end{array}$ & $\begin{array}{l}\text { delta TIm } \\
\text { of }\end{array}$ & & $\begin{array}{l}\text { Avg U } \\
\text { Btu/hr/sqft }\end{array}$ & & $\begin{array}{l}\text { area } \\
\text { sqft }\end{array}$ & & $\begin{array}{l}\text { cost } \\
1994 \$\end{array}$ & \\
\hline 0.01068 & 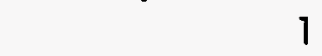 & 212 & 71 & 75.9471 & & 19.3917 & & 0.0482 & & \\
\hline 30 & 2,809 & 595,028 & $1.99 E+05$ & 75.9471 & & 19.3917 & & 135.4 & & $\$ 6,700$ \\
\hline 300 & 28,090 & $5,950,281$ & $1.99 E+06$ & 75.9471 & & 19.3917 & & 1354.2 & & $\$ 28,900$ \\
\hline 1000 & 93,633 & $19,834,270$ & $6.65 E+06$ & 75.9471 & & 19.3917 & & 4514.0 & & $\$ 84,400$ \\
\hline \multicolumn{11}{|l|}{ INTER2B } \\
\hline $\begin{array}{l}\text { Wood feed } \\
\text { bone dry tpd }\end{array}$ & $\begin{array}{l}\text { Wood feed } \\
\text { dried } \mathrm{lb} / \mathrm{hr}\end{array}$ & $\begin{array}{ll}\mathrm{H} 2 \text { produced } & \text { duty } \\
\text { scfd } & \text { Btu/hr }\end{array}$ & $\begin{array}{l}\text { delta TIm } \\
\text { of }\end{array}$ & & $\begin{array}{l}\text { Avg U } \\
\text { Btu/hr/sqft }\end{array}$ & & $\begin{array}{l}\text { area } \\
\text { sqft }\end{array}$ & & $\begin{array}{l}\text { cost } \\
1994 \$\end{array}$ & \\
\hline 0.01068 & काष & 212 & 60.3 & 58.4995 & & 14.4888 & & 0.0711 & & \\
\hline 30 & 2,809 & 595,028 & $1.69 E+05$ & 58.4995 & & 14.4888 & & 199.8 & & $\$ 8,200$ \\
\hline 300 & 28,090 & $5,950,281$ & $1.69 E+06$ & 58.4995 & & 14.4888 & & 1998.4 & & $\$ 40,000$ \\
\hline 1000 & 93,633 & $19,834,270$ & $5.65 E+06$ & 58.4995 & & 14.4888 & & 6661.3 & & $\$ 124,300$ \\
\hline
\end{tabular}




\section{:ACTORS}

\section{IIMARY REFORMER}

\begin{tabular}{|c|c|c|c|}
\hline $\begin{array}{l}\text { 'ood feed } \\
\text { one dry tpd }\end{array}$ & $\begin{array}{l}\text { Wood feed } \\
\text { dried lb/hr }\end{array}$ & $\begin{array}{l}\text { H2 produced } \\
\text { scfd }\end{array}$ & $\begin{array}{l}\text { Heat duty } \\
\text { MMBtu/hr }\end{array}$ \\
\hline 0.01068 & 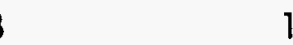 & $1 \quad 212$ & $5.56 \mathrm{E}-04$ \\
\hline 30 & 2,809 & 595,028 & 1.562 \\
\hline 300 & 28,090 & $5,950,281$ & 15.620 \\
\hline 1000 & 93,633 & $19,834,270$ & 52.067 \\
\hline \multicolumn{4}{|l|}{ eparation System } \\
\hline \multirow{2}{*}{\multicolumn{3}{|c|}{$\begin{array}{l}\text { SA SYSTEM } \\
\text { Istalled cost of PSA for } 4.05 \text { MMSCFD } \\
\text { /SCFD }\end{array}$}} & \\
\hline & & & $\$ 1,025,000$ \\
\hline $\begin{array}{l}\text { lood feed } \\
\text { one dry tpd }\end{array}$ & $\begin{array}{l}\text { Wood feed } \\
\text { dried lb/hr }\end{array}$ & $\begin{array}{l}\text { H2 produced } \\
\text { scfd }\end{array}$ & $\begin{array}{l}\text { cost } \\
\$\end{array}$ \\
\hline 0.01068 & 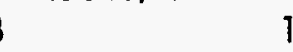 & 212 & \\
\hline 30 & 2,809 & 595,028 & $\$ 150,594$ \\
\hline 300 & 28,090 & $5,950,281$ & $\$ 1,505,935$ \\
\hline 1000 & 93,633 & $19,834,270$ & $\$ 5,019,784$ \\
\hline
\end{tabular}


尔

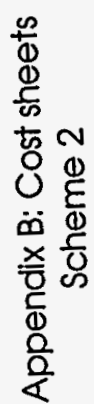

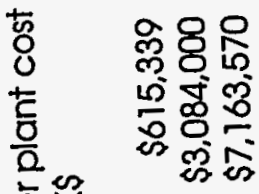

$\Phi$

密总

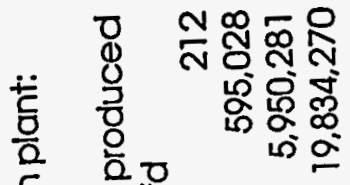

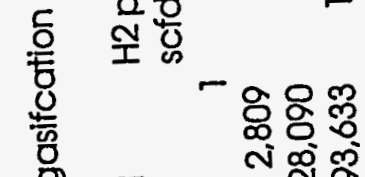

ㅁํㅇ 웡

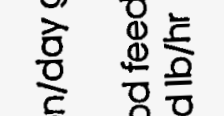

항

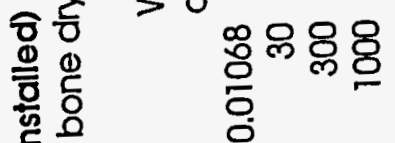

ธํㅠ ช ํㅠ

ธ。

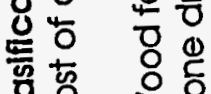

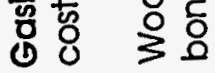




\section{apital Requirements}

\section{xpltal expenso}

trumentation

sing

sildings

xd Improvements

vice facillites

$$
\text { nd }
$$

gineering and construction

untingencles

juipment capHa

'ood feed

गne dry tpd

Wood feed
drled lb/hr

H2 produced untstalled
scfd

instaliation

other equipment

Installed

total equipment cost

$1994 \$$

$\begin{array}{rrrr}30 & 2,809 & 595,028 & \$ 572,940 \\ 300 & 28,090 & 5,950,281 & \$ 3,219,070\end{array}$

$\begin{array}{rrrr}300 & 28,090 & 5,950,281 & \$ 3,219,070\end{array}$

$93,033 \quad 19,834,270$

$\$ 9,035,813$

$\begin{array}{rr}\$ 765,932 & \$ 1,608,154 \\ \$ 4,589,935 & \$ 9,321,968 \\ \$ 12,183,354 & \$ 25,466,000\end{array}$

\section{total unistalled}

capital

\section{$\$ 1,093,982$}

$\$ 6,341,475$

\section{ther fixed caplital investment}

lood feed

Wood feed

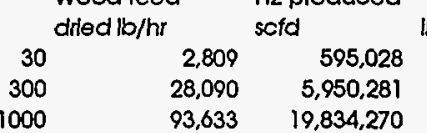

1

dinvestment

\section{Ital fixed capilid investment}

$\begin{array}{ll}\text { lood feed } & \text { Wood feed } \\ \text { lone dry tpd } & \text { dried lb/hr }\end{array}$

\begin{tabular}{|c|c|c|c|}
\hline \multicolumn{2}{|c|}{ drled lb/hr } & \multicolumn{2}{|c|}{ sefd } \\
\hline 30 & 2,809 & 595,028 & $\$ 5,054,199$ \\
\hline 300 & 28,090 & $5,950,281$ & $\$ 29,297,614$ \\
\hline 1000 & 93,633 & $19,834,270$ & $\$ 80,035,999$ \\
\hline
\end{tabular}

Vorking capital

Vood feed

$18 \%$ of the capital expenditures estimated so far.

\begin{tabular}{lrrr} 
Wood feed & \multicolumn{2}{c}{$\begin{array}{l}18 \% \text { of the capltal expenditures } \\
\text { H2 produced }\end{array}$} \\
drled lb/hr & \multicolumn{2}{l}{ scfdr } & working capttal \\
30 & 2,809 & 595,028 & $\$ 909,756$ \\
300 & 28,090 & $5,950,281$ & $\$ 5,273,571$ \\
00 & 93,633 & $19,834,270$ & $\$ 14,406,480$
\end{tabular}




\section{Operating costs}

\section{electricity cost}

on-line factor

\section{Electricity}

Wood feed

bone dry tpd

0.01068
30
300
1000

\section{$0.05 \$ / \mathrm{kWh}$}

0.9

\begin{tabular}{lrrrr} 
Wood feed & \multicolumn{3}{c}{$\begin{array}{l}\text { H2 produced power requiremer cost } \\
\text { scfd }\end{array}$} & \multicolumn{2}{c}{$\begin{array}{l}\text { hp } \\
\text { dried lb/hr }\end{array}$} \\
\hline 1 & 212 & 0.152 & \\
2,809 & 595,028 & 427.896 & $\$ 125,794$ \\
28,090 & $5,950,281$ & 4278.963 & $\$ 1,257,943$ \\
93,633 & $19,834,270$ & 14263.210 & $\$ 4,193,145$
\end{tabular}

\section{Waier}

for gasification

for reforming

for steam generation

BFW cost

\section{Wood feed}

bone dry tpd
$0.45 \mathrm{lb} / \mathrm{lb} \mathrm{bdw}$

$0.64 \mathrm{lb} / \mathrm{lb}$ bdw

$2.97 \mathrm{lb} / \mathrm{lb} \mathrm{bdw}$

$\$ 0.33 \$ / 1000$ liters

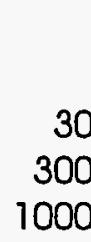

Wood feed dried lb/hr
H2 produced for gasification scfd

2,809

28,090

93,633

595,028
$5,950,281$

$19,834,270$

\section{for reforming
1000 liters/year}

2.01

20.09

66.95
2.86

28.63

95.43

for steam generatioltotal BFW 1000 liters/year

13.29

132.89

442.97

1000 liters/year

\section{Operating costs of PSA}

\section{Wood feed}

bone dry tpd

\begin{tabular}{rr}
\multicolumn{2}{c}{ Wood feed } \\
dried lb/hr \\
30 & 2,809 \\
300 & 28,090 \\
1000 & 93,633
\end{tabular}

$\begin{array}{lll}\text { H2 produced op cost } & \text { cost } \\ \text { scfd } & \text { \$/1000 SCF } & \$ / y r \\ 595,028 & \$ 6.50 \\ 5,950,281 & \$ 6.50 \\ 19,834,270 & \$ 6.50\end{array}$

$\$ 3,868$

$\$ 38,677$

$\$ 128,923$ 
abor

Vood feed

sone dry tpd

\begin{tabular}{rrr}
\multicolumn{2}{c}{ Wood feed } & H2 produced operator \\
drled lb/hr & scfd \\
30 & 2,809 & 595,028 \\
300 & 28,090 & $5,950,281$ \\
1000 & 93,633 & $19,834,270$
\end{tabular}

personnel and their cost per year

formen supervisors
$\$ 28,700$ formen $\$ 30,500$ $\begin{array}{ll}3 & 1 \\ 6 & 2 \\ 8 & 2\end{array}$ $\$ 39,300 \$ / y r$ total labor cost $\$ 155,900$ $\$ 272,500$ $\$ 329,900$

\section{3yproduct credit: steam}

¡00 psig sieam itream steam6 otal

Nood feed sone dry tpd

100 psig steam stream steamla stream steam2a stream steam $2 b$ stream steam4

\section{$0.2838 \mathrm{lb} / \mathrm{lb}$ dried wood}

0.2838

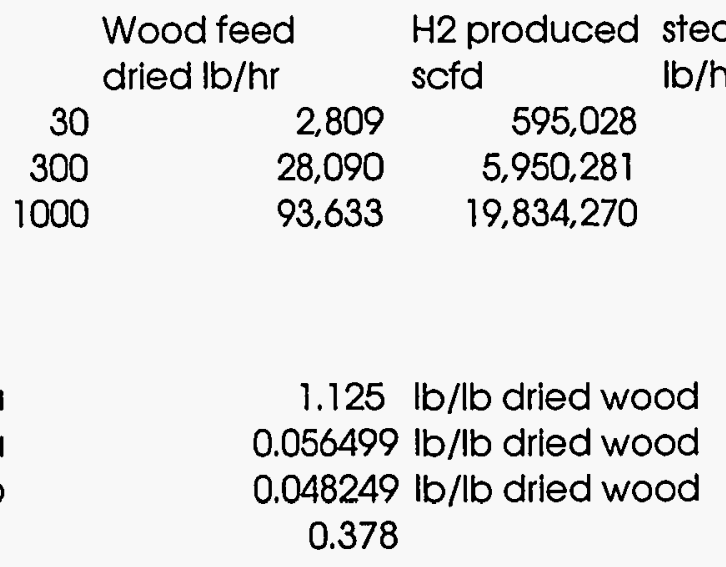




\section{stream steam5} total

$0.754 \mathrm{lb} / \mathrm{lb}$ dried wood 2.362048

\section{Wood feed} bone dry tpd

\begin{tabular}{rrr}
\multicolumn{2}{c}{$\begin{array}{l}\text { Wood feed } \\
\text { dried } \mathrm{lb} / \mathrm{hr}\end{array}$} & \multicolumn{2}{c}{ H2 produced } \\
scfd \\
30 & 2,809 & 595,028 \\
300 & 28,090 & $5,950,281$ \\
1000 & 93,633 & $19,834,270$
\end{tabular}

\section{$\mathrm{lb} / \mathrm{hr}$}

\begin{tabular}{|c|c|}
\hline & $\mathrm{kg} /$ year \\
\hline 6,635 & $26,363.87$ \\
\hline 66,350 & $263,638.65$ \\
\hline 221,166 & 878,795.51 \\
\hline
\end{tabular}

\begin{tabular}{lr}
\multicolumn{2}{c}{ yearly revenue } \\
\multicolumn{2}{|c}{$\$$} \\
$\$ 5.18$ & $\$ 136,564.82$ \\
$\$ 5.18$ & $\$ 1,365,648.22$ \\
$\$ 5.18$ & $\$ 4,552,160.74$
\end{tabular}


scheme 3: no low femperature shlft reactor

Capltal investment and operating costs al bottom of spreadsheet

Pumps and Compressors

WATPUMP

Wood feed

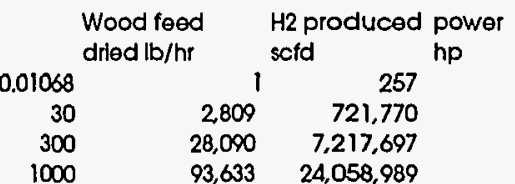

flowrote
f $3 / \mathrm{hr}$

flowrate
gal/min

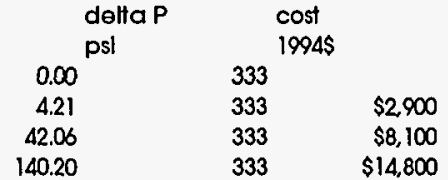

\section{5 (syncompr water pump)}

\begin{tabular}{|c|c|c|c|c|c|c|c|}
\hline $\begin{array}{l}\text { Wood feed } \\
\text { bone dry tpd }\end{array}$ & $\begin{array}{l}\text { Wood feed } \\
\text { drled lb/hr }\end{array}$ & $\begin{array}{l}\text { H2 produced power } \\
\text { sefd }\end{array}$ & & & & & \\
\hline 0.01058 & 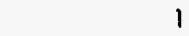 & 257 & 0.001 & 0.011 & 0.00 & 510 & \\
\hline 30 & 2809 & 721,770 & 4.018 & 32.0 & 3.99 & 510 & $\$ 3,240$ \\
\hline 300 & 28,090 & $7,217,697$ & 40.180 & 320.3 & 39.93 & 510 & $\$ 9,720$ \\
\hline 1000 & 93,633 & $24,058,989$ & 133.933 & 1067.6 & 133.10 & 510 & $\$ 25,160$ \\
\hline
\end{tabular}

B3 (Hcool water pump)

Wood feed

$\begin{array}{ll}\text { Wood feed } & \text { H2 produced power } \\ \text { drled lb/hr } & \text { sefd }\end{array}$

0.001
2.763

0.012
33.7

92.111

337.4

1124.5

140.20

$\$ 14,800$

bone dry tpd 0.01068

2,809

300

$93,633 \quad 24,058,989$

flowrate $\mathrm{gal} / \mathrm{min}$

0.001

20.045

0.006
16.8

16.8
167.9
559.7

$\begin{array}{cc}\text { delta P }_{\text {psl }} \text { cost }^{\text {1994\$ }} \\ 0.00 & 485.304 \\ 2.09 & 485.304 \\ 20.93 & 485.304 \\ 69.78 & 485.304\end{array}$

$\$ 2.590$

$\$ 6,480$

87 (psacool water pump)

Wood feed

\begin{tabular}{crr}
$\begin{array}{c}\text { Wood feed } \\
\text { driled lb/hr }\end{array}$ & \multicolumn{2}{c}{$\begin{array}{c}\text { H2 produced power } \\
\text { scfd }\end{array}$} \\
0.01068 & \multicolumn{1}{c}{$\begin{array}{l}\text { hp } \\
30\end{array}$} & 257 \\
300 & 2809 & 721,770 \\
1000 & 28,090 & $7.217,697$ \\
100 & 93,633 & $24,058,989$
\end{tabular}

flowrate
\#3/hr
0.000
1.076
10.758

$0_{0.016^{\text {flowrate }}}^{\text {gal/mn }}$

45.4
454.5

35.861

454.5
1515.0

69.78

$\$ 2580$

\section{B13 (stmgen6 water pump)}

\begin{tabular}{|c|c|c|c|c|c|c|c|c|}
\hline $\begin{array}{l}\text { Wood feed } \\
\text { bone dry tpd }\end{array}$ & $\begin{array}{l}\text { Wood feed } \\
\text { dried lb/hr }\end{array}$ & $\begin{array}{l}\text { H2 produced } \\
\text { sefd }\end{array}$ & $\begin{array}{l}\text { power } \\
\text { hp }\end{array}$ & & & & & \\
\hline 0.01058 & 1 & 257 & & 0.001 & 0.008 & 0.00 & 310 & \\
\hline 30 & 2809 & 721,770 & & 1.683 & 22.1 & 2.75 & 310 & $\$ 2,400$ \\
\hline 300 & 28,090 & $7,217,697$ & & 16.826 & 220.7 & 27.51 & 310 & $\$ 5,670$ \\
\hline 1000 & 93,633 & $24,058,989$ & & 56.088 & 735.5 & 91.70 & 310 & $\$ 11,340$ \\
\hline
\end{tabular}


pumpl

Wood feed

Wood feed H2 produced power

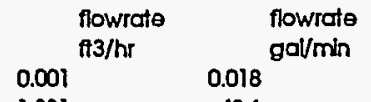

0.01068

dried lb/hr scfd hp

30
300

$\begin{array}{rr}2,809 & 257 \\ 28,090 & 721,770\end{array}$

$28,090 \quad 7,217,697$

0.001
1.831

1.831
18.307

49.6

61.023

496.2
1653.8

delta
0.00
6.19
61.86
206.19

cost
15045
150
150
150

$\$ 2000$

$\$ 4,200$

pump2

Wood feed
bone dy tpd Wood feed H2 produced power

flowrate

flowrate
gal/mln
$0.018^{-6}$
49.6
496.2
1653.8

delta P
0.00
6.19
61.86
206.19

\begin{tabular}{ll}
\multicolumn{1}{c}{ cost } & \\
$1994 \$$ & \\
150 & \\
150 & $\$ 2,000$ \\
150 & $\$ 4,200$ \\
150 & $\$ 7,500$
\end{tabular}

pump3

Wood feed
bone dry tpd

\begin{tabular}{rrr} 
Wood feed & \multicolumn{2}{c}{$\begin{array}{l}\text { H2 produced power } \\
\text { scfd }\end{array}$ hp } \\
0.01068 & \multicolumn{1}{c}{$\begin{array}{c}\text { drled lb/hr } \\
30\end{array}$} & 257 \\
300 & 28,090 & 721,770 \\
1000 & 93,633 & $7,217,697$ \\
& $24,058,989$
\end{tabular}

$\begin{array}{cc}\text { flowrate } & \text { flowrate } \\ \text { f3/hr } & \text { gal/min } \\ 0.001 & 0.018 \\ 1.831 & 49.6 \\ 18.307 & 496.2 \\ 61.023 & 19.2\end{array}$

${ }_{\text {deltap }}^{\text {psi }}$
0.00
6.19
61.86
206.19

\begin{tabular}{ll}
\multicolumn{2}{c}{ cost } \\
$1994 \$$ \\
150 & \\
150 & $\$ 2,000$ \\
150 & $\$ 4,200$ \\
150 & $\$ 7,500$
\end{tabular}

pump4

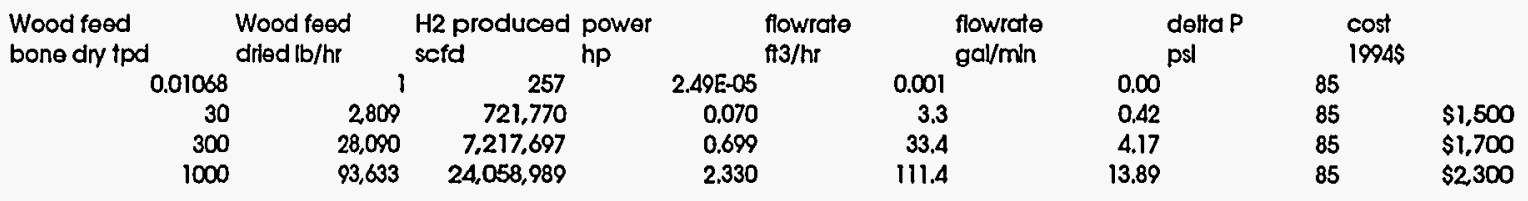

pump5

Wood feed
bone dy tpd

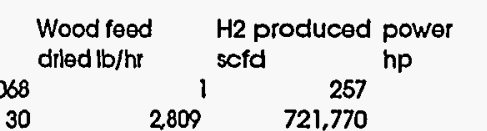

\begin{tabular}{lc} 
flowrote & \multicolumn{1}{c}{$\begin{array}{c}\text { flowrate } \\
\text { ft3/hr }\end{array}$} \\
0.000 & $0.001^{\text {gal/min }}$ \\
0.060 & 2.9 \\
0.597 & 28.5 \\
1.989 & 95.1
\end{tabular}

\begin{tabular}{ll} 
delta P & \multicolumn{1}{c}{ cost } \\
psi & 1994\$ \\
0.00 & 85 \\
0.36 & 85 \\
3.56 & 85 \\
11.86 & 85
\end{tabular}

cost
$1994 \$$


$\$ 1,500$
$\$ 1,700$
$\$ 2,200$

OFFCOMPR

\begin{tabular}{|c|c|c|c|}
\hline $\begin{array}{l}\text { Wood feed } \\
\text { bone dry tpd }\end{array}$ & $\begin{array}{l}\text { Wood feed } \\
\text { drled lb/hr }\end{array}$ & $\begin{array}{l}\text { H2 produced } \\
\text { sefd }\end{array}$ & $\begin{array}{l}\text { first stage } \\
\text { power } \\
\text { hp }\end{array}$ \\
\hline 0.01068 & 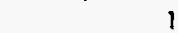 & 257 & \\
\hline 30 & 2809 & 721,770 & \\
\hline 300 & 28,090 & $7,217,697$ & \\
\hline 1000 & 93,633 & $24,058,989$ & \\
\hline
\end{tabular}

\begin{tabular}{rr} 
& \multicolumn{2}{c}{ cost } \\
& \\
0.024 & \\
67.2 & $\$ 79,100$ \\
671.6 & $\$ 422,000$ \\
2238.8 & $\$ 1,042,600$
\end{tabular}

second stage
power
hp
$\begin{array}{lrr}\text { cost } & \\ \text { hp } & 0.02944 & \\ & 82.8 & \$ 92,600 \\ & 828.4 & \$ 494,000 \\ & 2761.2 & \$ 1,220,500\end{array}$

\begin{tabular}{|c|c|c|c|c|}
\hline $\begin{array}{l}\text { thlird stage } \\
\text { power } \\
\text { hp }\end{array}$ & $\begin{array}{l}\text { cost } \\
19945\end{array}$ & $\begin{array}{l}\text { fourth stage } \\
\text { power } \\
\text { hp }\end{array}$ & $\begin{array}{l}\text { cost } \\
1994 \$\end{array}$ & total cost \\
\hline 0.0281 & & 0.0281 & & \\
\hline 78.9 & $\$ 89,300$ & 78.9 & $\$ 89,300$ & $\$ 350,3$ \\
\hline 789.3 & $\$ 476,400$ & 789.3 & $\$ 476,400$ & $\$ 1,868,800$ \\
\hline 2631.1 & $\$ 1,177,000$ & 2631.1 & $\$ 1,177,000$ & $\$ 4,617,10$ \\
\hline
\end{tabular}

$$
\text { Scheme } 3
$$




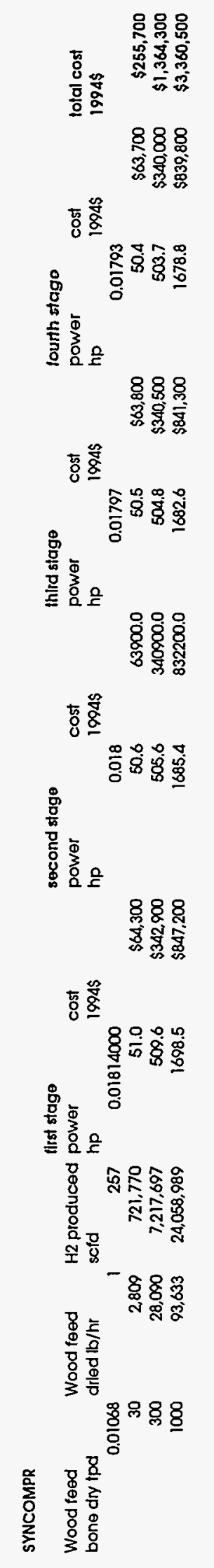




\section{Heat Exchangers and Heaters}

\section{GSTMGEN}

Wood feed

bone dry tpd

Wood feed H2 produced duty dried lb/hr scfd Btu/hr 0.01068

300

1000

$\begin{array}{rr}1 & 257 \\ 2,809 & 721,770 \\ 28,090 & 7,217,697 \\ 93,633 & 24,058,989\end{array}$

632.9
${ }^{\circ} \mathrm{F}$
$1.78 \mathrm{E}+06$
$1.78 \mathrm{E}+07$
$5.93 \mathrm{E}+07$

delta TIm

Avg U
Btu/hr/sqft

679.2815

679.2815

679.2815

679.2815

$5.93 \mathrm{E}+07$

\begin{tabular}{cc} 
area & \multicolumn{2}{c}{ cost } \\
sqft & \multicolumn{2}{c}{$1994 \$$} \\
192.0261 & 0.0049 \\
192.0261 & 13.6 \\
192.0261 & 136.3 \\
192.0261 & 454.3
\end{tabular}

$\$ 1,200$

$\$ 7,100$

$\$ 13,000$

\section{LTCOOL}

Wood feed

bone dry tpd

\begin{tabular}{|c|c|c|}
\hline & $\begin{array}{l}\text { Wood feed } \\
\text { drled lb/hr }\end{array}$ & $\begin{array}{l}\text { H2 produced } \\
\text { scfd }\end{array}$ \\
\hline 0.01068 & - & 257 \\
\hline 30 & 2,809 & 721,770 \\
\hline 300 & 28,090 & $7,217,697$ \\
\hline 1000 & 93,633 & $24,058,989$ \\
\hline
\end{tabular}

\begin{tabular}{rr}
\multicolumn{2}{c}{$\begin{array}{c}\text { delta } \pi m \\
\text { of }\end{array}$} \\
365.5 & 326.6936 \\
$1.03 E+06$ & 326.6936 \\
$1.03 E+07$ & 326.6936 \\
$3.42 E+07$ & 326.6936
\end{tabular}

Avg U

Btu/hr/sqft

area
sqft
85.7387
85.7387
85.7387
85.7387

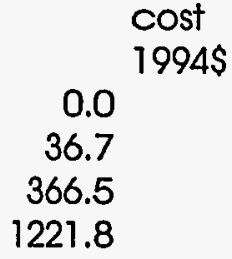

\section{PSACOOL}

\begin{tabular}{|c|c|c|c|c|}
\hline $\begin{array}{l}\text { Wood feed } \\
\text { bone dry tpd }\end{array}$ & $\begin{array}{l}\text { Wood feed } \\
\text { dried lb/hr }\end{array}$ & $\begin{array}{l}\text { H2 produced } \\
\text { scfd }\end{array}$ & $\begin{array}{l}\text { duty } \\
\text { Błu/hr }\end{array}$ & $\begin{array}{l}\text { delta TIm } \\
{ }^{\circ} \mathrm{F}\end{array}$ \\
\hline 0.01068 & (n) & 257 & & 967.7 \\
\hline 30 & 2,809 & 721,770 & & $2.72 E+06$ \\
\hline 300 & 28,090 & $7,217,697$ & & $2.72 E+07$ \\
\hline 1000 & 93,633 & $24,058,989$ & & $9.06 E+07$ \\
\hline
\end{tabular}

Avg U
Btu/hr/sqft
120
120
120
120

area
sqft
85
85
85
85

\begin{tabular}{rr}
\multicolumn{2}{c}{ cost } \\
& \\
0.1 & \\
$2694 \$$ & \\
2665.0 & $\$ 9,300$ \\
8883.2 & $\$ 51,600$ \\
& $\$ 167,800$
\end{tabular}

\section{STMGEN6}

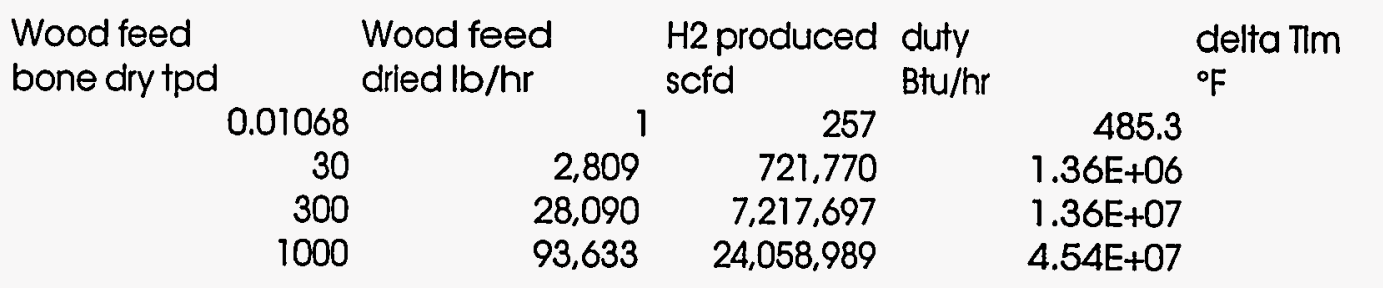

\begin{tabular}{lr}
\multicolumn{1}{c}{$\begin{array}{l}\text { Avg U } \\
\text { Btu/hr/sqft }\end{array}$} & $\begin{array}{l}\text { area } \\
\text { sqft }\end{array}$ \\
38.57 & 149.67 \\
38.57 & 149.67 \\
38.57 & 149.67 \\
38.57 & 149.67
\end{tabular}

\begin{tabular}{rr}
\multicolumn{2}{c}{ cost } \\
\\
0.1 & \\
236.1 & \\
2361.4 & $\$ 8,700$ \\
7871.4 & $\$ 46,300$ \\
& $\$ 147,700$
\end{tabular}


SYNCOOLI / REFHTR (MODELI)

bone dry tpd

Wood feed 0.01068

300

1000 dried lb/hr

2,809
28,090

93,633
H2 produced duty scfd

257

$7,217,697$

$24,058,989$
Btu/hr

27.1
$7.61 E+04$
$7.61 E+05$
$2.54 E+06$

delta TIm

Avg U

Btu/hr/sqft

1256.2968

1256.2968

1256.2968

1256.2968

Avg U
Btu/hr/sqft $\quad$ area
149.6937
149.6937
149.6937
149.6937

\begin{tabular}{|c|c|}
\hline \multicolumn{2}{|c|}{ cost } \\
\hline 0.0 & \\
\hline 0.4 & $\$ 1,000$ \\
\hline 4.0 & $\$ 1,100$ \\
\hline 3.5 & $\$ 1,200$ \\
\hline
\end{tabular}

\section{REFSTM / COMBCOOL (MODEL2)}

Wood feed Wood feed

bone dry tpd

0.01068
30
300
1000

dried lb/hr

30
300

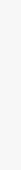

\begin{tabular}{|c|c|c|}
\hline 4 & $\begin{array}{l}2 \text { produced } \\
\text { cfd }\end{array}$ & \\
\hline 1 & 257 & \\
\hline 2,809 & 721,770 & \\
\hline 28,090 & $7,217,697$ & \\
\hline 93,633 & $24,058,989$ & \\
\hline
\end{tabular}

\begin{tabular}{rrrrr}
\multicolumn{2}{c}{$\begin{array}{c}\text { delta TIm } \\
\text { of }\end{array}$} & \multicolumn{2}{c}{$\begin{array}{l}\text { Avg U } \\
\text { Btu/hr/sqft }\end{array}$} & \multicolumn{2}{c}{$\begin{array}{c}\text { cost } \\
\text { sqft }\end{array}$} \\
901.8 & 537.7543 & 186.5534 & 0.0090 & $1994 \$$ \\
$2.53 \mathrm{E}+06$ & 537.7543 & 186.5534 & 25.3 & $\$ 1,300$ \\
$2.53 \mathrm{E}+07$ & 537.7543 & 186.5534 & 252.5 & $\$ 9,000$ \\
$8.44 \mathrm{E}+07$ & 537.7543 & 186.5534 & 841.7 & $\$ 20,000$
\end{tabular}

\section{SYNCOMPR INTERSTAGE COOLERS}

\section{INTERIA}

\begin{tabular}{|c|c|c|c|c|c|c|}
\hline $\begin{array}{l}\text { Wood feed } \\
\text { bone dry tpd }\end{array}$ & & & $\begin{array}{l}\text { H2 produced } \\
\text { scfd }\end{array}$ & $\begin{array}{l}\text { hearxi } \\
\text { duty } \\
\text { Btu/hr }\end{array}$ & \multicolumn{2}{|r|}{$\begin{array}{l}\text { delta TIm } \\
{ }^{\circ} \mathrm{F}\end{array}$} \\
\hline & & 1 & 257 & & 510 & \\
\hline & & 2,809 & 721,770 & & $1.43 E+06$ & \\
\hline & & 28,090 & $7,217,697$ & & $1.43 E+07$ & \\
\hline & & 93,633 & $24,058,989$ & & $4.78 E+07$ & \\
\hline
\end{tabular}

\section{INTERIB}

Wood feed bone dry tpd

\section{FLASH DRUM}

\section{Wood feed} dried lb/hr

\section{FLASH DRUM}

2809
0.01068

30

$$
300
$$

1000

\section{heatxl}

H2 produced duty scfd Btu/hr 257 2,809 28,090 93,633

delta TIm
510
$1.43 \mathrm{E}+06$
$1.43 \mathrm{E}+07$
$4.78 \mathrm{E}+07$

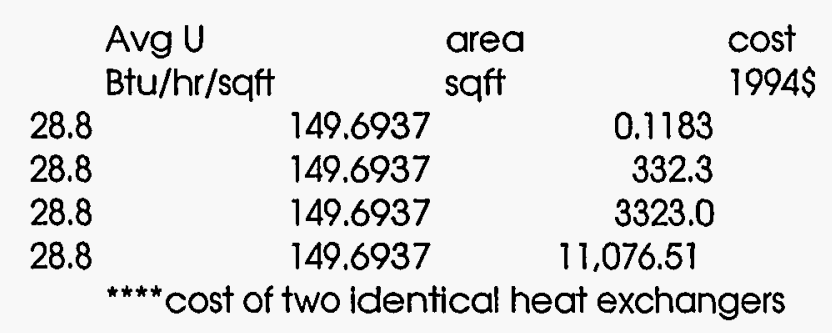

$\$ 11,100$ $\$ 63,100$ $\$ 206,400$ 
INTERIC

FLASH DRUM

Wood feed Wood feed H2 produced duty

bone drytpd dried lb/hr scfd

Buty/hr

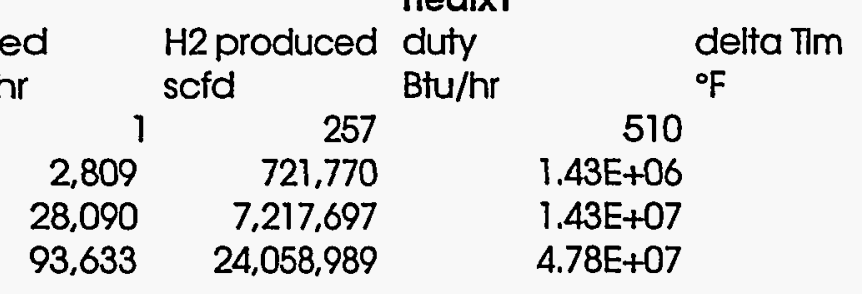

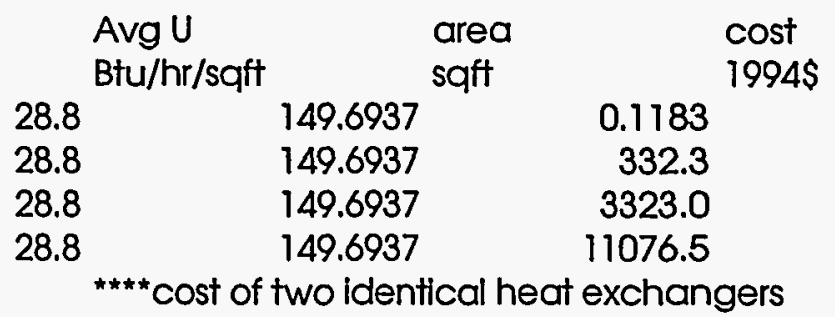

$\$ 11,100$

$\$ 63,100$

$\begin{array}{rrrr}1068 & 1 & 257 & 510 \\ 30 & 2,809 & 721,770 & 1.43 E+06 \\ 300 & 28,090 & 7,217,697 & 1.43 E+07 \\ 1000 & 93,633 & 24,058,989 & 4.78 E+07\end{array}$

\section{OFFCOMPR INTERSTAGE COOLERS}

\section{INTER2A}

\begin{tabular}{|c|c|c|c|c|c|c|c|c|}
\hline $\begin{array}{l}\text { Wood feed } \\
\text { bone dry tpd }\end{array}$ & $\begin{array}{l}\text { Wood feed } \\
\text { dried lib/hr }\end{array}$ & $\begin{array}{l}+2 \text { produced } \\
\text { cfd }\end{array}$ & $\begin{array}{l}\text { duty } \\
\text { Btu/hr }\end{array}$ & & $\begin{array}{l}\text { Avg U } \\
\text { Btu/hr/sqft }\end{array}$ & & & $\begin{array}{l}\text { cost } \\
1994 \$\end{array}$ \\
\hline 0.01068 & 1 & 257 & 71 & 75.9471 & & 19.3917 & 0.0482 & \\
\hline 30 & 2,809 & 721,770 & $1.99 E+05$ & 75.9471 & & 19.3917 & 135.4 & $\$ 6,700$ \\
\hline 300 & 28,090 & $7,217,697$ & $1.99 E+06$ & 75.9471 & & 19.3917 & 1354.2 & $\$ 28,900$ \\
\hline 1000 & 93,633 & $24,058,989$ & $6.65 E+06$ & 75.9471 & & 19.3917 & 4514.0 & $\$ 84,400$ \\
\hline
\end{tabular}

\section{INTER2B}

\begin{tabular}{|c|c|c|c|c|c|c|c|c|}
\hline $\begin{array}{l}\text { Wood feed } \\
\text { bone dry tpd }\end{array}$ & $\begin{array}{l}\text { Wood feed } \\
\text { dried lb/hr }\end{array}$ & $\begin{array}{l}\text { H2 produced } \\
\text { scfd }\end{array}$ & $\begin{array}{l}\text { duty } \\
\text { Btu/hr }\end{array}$ & & $\begin{array}{l}\text { Avg U } \\
\text { Btu/hr/sqft }\end{array}$ & & & $\begin{array}{l}\text { cost } \\
1994 \$\end{array}$ \\
\hline 0.01068 & (2) & 257 & 60.3 & 58.4995 & & 14.4888 & 0.0711 & \\
\hline 30 & 2,809 & 721,770 & $1.69 E+05$ & 58.4995 & & 14.4888 & 199.8 & $\$ 8,200$ \\
\hline 300 & 28,090 & $7,217,697$ & $1.69 E+06$ & 58.4995 & & 14.4888 & 1998.4 & $\$ 40,000$ \\
\hline 1000 & 93,633 & $24,058,989$ & $5.65 E+06$ & 58.4995 & & 14.4888 & 6661.3 & $\$ 124,300$ \\
\hline
\end{tabular}


REACTORS

\section{HTSHIFT}

SV $(1 / h r)=$

helght/dlameter

Wood feed

bone dry tpd 0.01068

1000

Wood feөd

drled $\mathrm{lb} / \mathrm{hr}$

$$
2,809
$$$$
28,090
$$

93,633

1000

2

* acfh = actual cublc feet per hour

\section{PRIMARY REFORMER}

\begin{tabular}{|c|c|c|c|}
\hline $\begin{array}{l}\text { Wood feed } \\
\text { bone dry tpd }\end{array}$ & $\begin{array}{l}\text { Wood feed } \\
\text { drled } \mathrm{lb} / \mathrm{hr}\end{array}$ & $\begin{array}{l}\text { H2 produced } \\
\text { scfd }\end{array}$ & $\begin{array}{l}\text { Heat duty } \\
\text { MMBtu/hr }\end{array}$ \\
\hline 0.01068 & 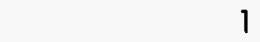 & 257 & 5.56E-04 \\
\hline 30 & 2,809 & 721,770 & 1.562 \\
\hline 300 & 28,090 & $7,217,697$ & 15.620 \\
\hline 1000 & 93,633 & $24,058,989$ & 52.067 \\
\hline Separation System & & & \\
\hline PSA SYSTEM & & & \\
\hline Installed cost of PSA fo & for 4.05 MMSCFD & & $\$ 1,025,000$ \\
\hline S/SCFD & & & 0.253 \\
\hline $\begin{array}{l}\text { Wood feed } \\
\text { bone dry tpd }\end{array}$ & $\begin{array}{l}\text { Wood feed } \\
\text { drled lb/hr }\end{array}$ & $\begin{array}{l}\text { H2 produced } \\
\text { scfd }\end{array}$ & $\begin{array}{l}\cos t \\
\$\end{array}$ \\
\hline 0.01068 & (n) & 257 & \\
\hline 30 & 2,809 & 721,770 & $\$ 182,670$ \\
\hline 300 & 28,090 & $7,217,697$ & $\$ 1,826,701$ \\
\hline 1000 & 93,633 & $24,058,989$ & $\$ 6,089,003$ \\
\hline
\end{tabular}

\begin{tabular}{|c|c|c|c|c|c|}
\hline $\begin{array}{l}\text { reactor volume } \\
\mathrm{ft3}\end{array}$ & $\begin{array}{l}\text { dlameter } \\
\mathrm{ft}\end{array}$ & $\begin{array}{l}\text { helght } \\
\text { ft }\end{array}$ & $\begin{array}{l}\text { pressure } \\
\text { psi }\end{array}$ & & \\
\hline 0.0008 & & 0.08 & 0.16 & 504 & \\
\hline 2.20 & & 1.12 & 2.24 & 504 & $\$ 6,700$ \\
\hline 22.01 & & 2.41 & 4.82 & 504 & $\$ 26,700$ \\
\hline 73.37 & & 3.60 & 7.20 & 504 & $\$ 56,200$ \\
\hline
\end{tabular}




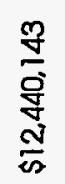
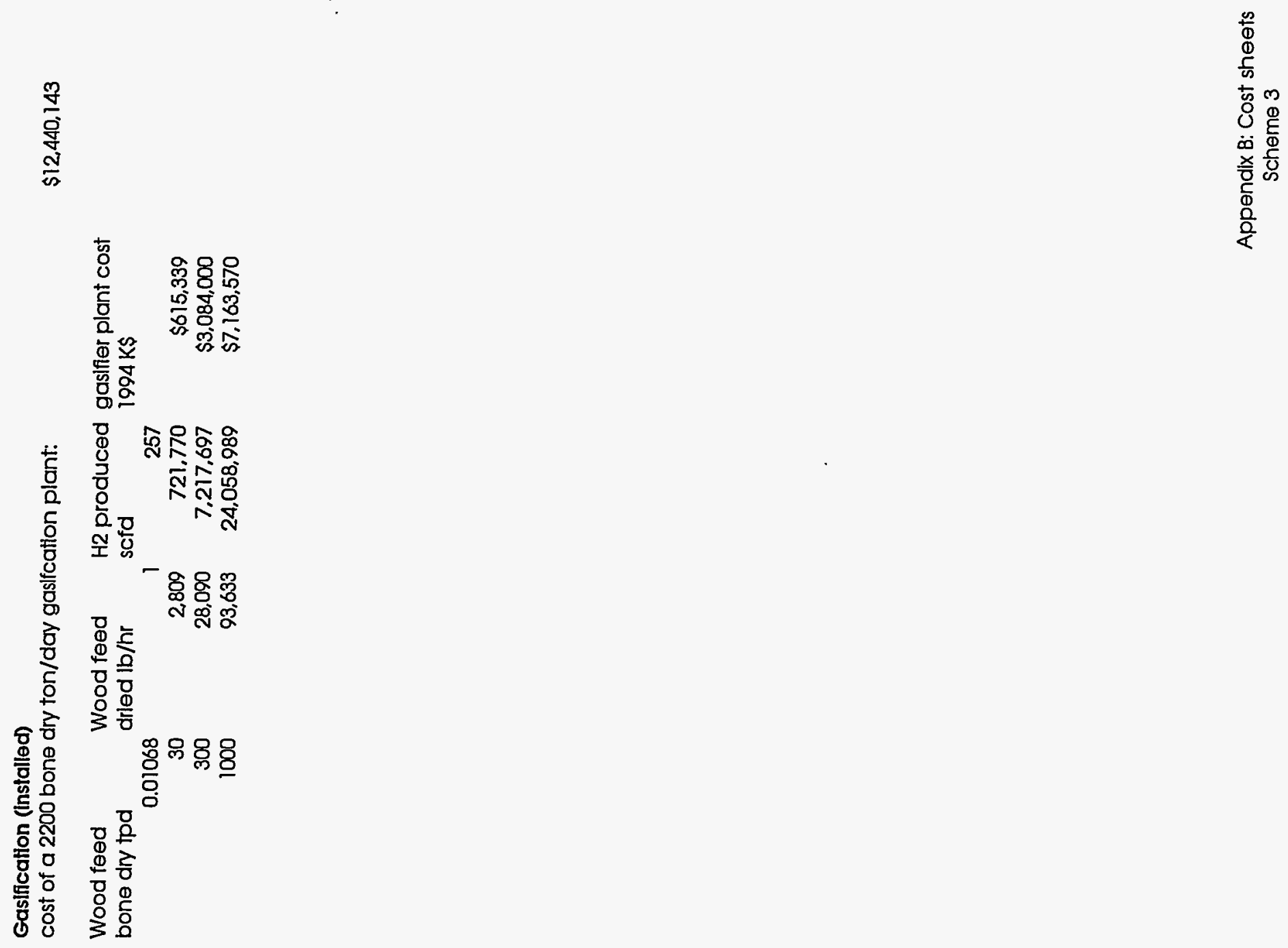


\section{pital Requirements}

\section{ipttal expense}

irumentation

ing

telingal

rd Improvements

vice facilitiles

d

gineering and construction

intingencles

ulpment capttal

\begin{abstract}
sod feed
\end{abstract}
Wood feed

drled lb/h

scto

$\%$ of purchased equipment cost

$18 \%$

$66 \%$

$11 \%$

$10 x$

$60 \%$

$74 \%$

$42 \%$

$\begin{array}{rrrr}30 & 2,809 & 721,770 & \$ 759,230 \\ 300 & 28,090 & 7,217,697 & \$ 4,024,870\end{array}$

$1000 \quad 93,633$

$24,058,989$
Installotion

cost

$\$ 356,838$
$\$ 1,891,689$

$\$ 4,822,770$

Installed

total equipment cost

19945

$\$ 1,914,077$

$\$ 10,827,260$

$\$ 28,336,557$

$\$ 4,910,70$

$\$ 13,252,573$ total unlstalled

capital

$\$ 1,302,093$

$\$ 7,365,483$

$\$ 19,276,569$

ther fixed captlal investmen

$\begin{array}{ll}\text { ood feed } & \text { Wood feed } \\ \text { sne dry tpd } & \text { dried lb/hr }\end{array}$

Jne dry tpd

H2 produced

scid Instrumentation pliping

Instrumentation piping electrical

$\$ 234,377$

$\$ 859,382$
$\$ 4,861,219$

bulldings

\$234,377 yard

\$130,209 senice facillitis land

$\$ 810,203 \quad \$ 1,325,787$

$\$ 1,325,787$

$\$ 736,548$

$\$ 2,120,423$

$\$ 1,927,657$

$\$ 911,465$
$\$ 5,155,838$

$\$ 13,493,598$

$\$ 78,126$

929

engineer

contingencles total related fixe

$\$ 14,264,661$

$\begin{array}{rr}\$ 546,879 & \$ 4,101,594 \\ \$ 3,093,503 & \$ 23,201,271\end{array}$

$\begin{array}{ll}\$ 3,093,503 & \$ 23,201,271 \\ \$ 8,096,159 & \$ 60,721,193\end{array}$

\section{Ifd flxed copitad investment}

'ood feed

Wood feed

H2 produced fixed caplto

sefd

\begin{tabular}{rrrr}
30 & dried lb/hr & \multicolumn{3}{c}{ scfd } & \\
30 & 2,809 & 721,770 & $\$ 6,015,671$ \\
300 & 28,090 & $7,217,697$ & $\$ 34,028,531$ \\
1000 & 93,633 & $24,058,989$ & $\$ 89,057,750$
\end{tabular}

$\begin{array}{rrrr}1000 & 93,633 & 24,058,989 & \$ 89,057,750\end{array}$

lorking caplita! lood feed

$18 \%$ of the cotlo

\begin{tabular}{rrrr} 
Wood feed & \multicolumn{3}{l}{$\begin{array}{l}\text { 18\% of the capltal expendltures estimated so far. } \\
\text { H2 produced }\end{array}$} \\
dried lb/hr & scfd & working captlal \\
30 & 2,809 & 721,770 & $\$ 1,082,821$ \\
300 & 28,090 & $7,217,697$ & $\$ 6,125,136$ \\
1000 & 93,633 & $24,058,989$ & $\$ 16,030,395$
\end{tabular}




\section{Operating costs}

electricity cost

on-line factor

Electricity

Wood feed

bone dry tpd

0.01068
30
300
1000

Wood feed

dried lb/hr

30
300

1000

\section{Water}

for gasification

for reforming

for steam generation

BFW cost

\section{Wood feed \\ bone dry tpd}

\section{$0.05 \$ / k W h$}

0.9

H2 produced power requireme cost

scfd

1

2,809

28,090

93,633

257
721,770
$7,217,697$

hp

0.188

527.391

5273.907

17579.690

$\$ 155,044$

$\$ 1,550,440$

$\$ 5,168,134$

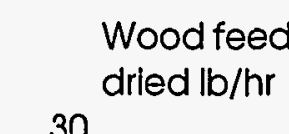

300

1000
$0.45 \mathrm{lb} / \mathrm{lb} \mathrm{bdw}$

$0.64 \mathrm{lb} / \mathrm{lb} \mathrm{bdw}$

$2.97 \mathrm{lb} / \mathrm{lb} \mathrm{bdw}$

$\$ 0.33 \$ / 1000$ liters dried $\mathrm{lb} / \mathrm{hr}$

2,809

28,090

93,633
H2 produced for gasification scfd

721,770
$7,217,697$

$24,058,989$

1000 liters/year

2.01
20.09
66.95

for reforming 1000 liters/year for steam generatioltotal BFW 1000 liters/year $\quad 1000$ liters/year

$\begin{array}{rrr}2.86 & 13.29 & 18.16 \\ 28.63 & 132.89 & 181.61 \\ 95.43 & 442.97 & 605.35\end{array}$

\section{Operating costs of PSA}

Wood feed

bone dry tpd

\begin{tabular}{rr}
\multicolumn{2}{c}{ Wood feed } \\
dried lb/hr \\
30 & 2,809 \\
300 & 28,090 \\
1000 & 93,633
\end{tabular}

$\begin{array}{lll}\text { H2 produced op cost } & \text { cost } \\ \text { scfd } & \$ / 1000 \text { SCF } & \$ / y r \\ 721,770 & \$ 6.50 \\ 7,217,697 & \$ 6.50 \\ 24,058,989 & \$ 6.50\end{array}$

$\$ 4,692$

$\$ 46,915$

$\$ 156,383$ 
sbor

'ood feed

one dry tpd

\begin{tabular}{rrr}
\multicolumn{2}{c}{ Wood feed } & \multicolumn{2}{c}{ H2 produced operators } \\
dried Ib/hr & scfd \\
30 & 2,809 & 721,770 \\
300 & 28,090 & $7,217,697$ \\
1000 & 93,633 & $24,058,989$
\end{tabular}

personnel and their cost per year $\$ 28,700$ formen

$\$ 30,500$ supervisors

3

6
8

1
2
2

$\$ 39,300 \$ / y r$

total labor cost

1

$1 \quad \$ 329,900$

\section{yproduct credit: steam}

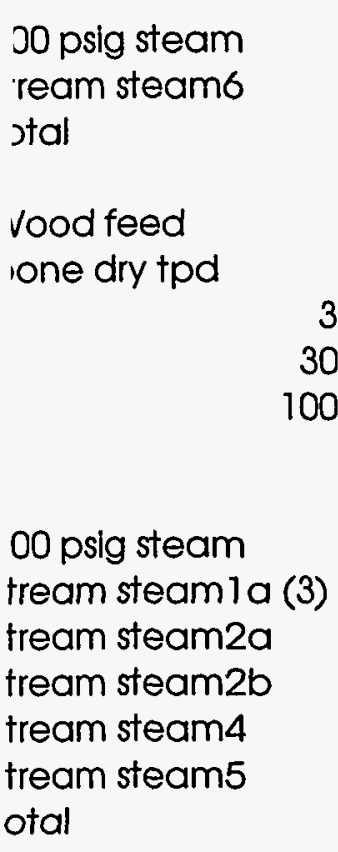

\section{0 psig steam} tream steam la (3) fream steam $2 a$ tream steam $2 b$ tream steam4 tream steam5 otal

steam produced steam produced selling price $\mathrm{lb} / \mathrm{hr}$

$\begin{array}{rr} & 1000 \mathrm{~kg} / \text { year } \\ 797 & 3,167.62 \\ 7,972 & 31,676.18 \\ 26,573 & 105,587.26\end{array}$

yearly revenue

$\$$

$\$ 24,960.83$

$\$ 249,608.27$

$\$ 7.88$

$\$ 7.88$
$1.1253 \mathrm{lb} / \mathrm{lb}$ dried wood $0.056499 \mathrm{lb} / \mathrm{lb}$ dried wood $0.048249 \mathrm{lb} / \mathrm{lb}$ dried wood 0.378

$0.754 \mathrm{lb} / \mathrm{lb}$ dried wood 2.362048 


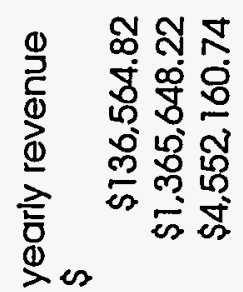

$\infty \infty \infty$ ผ

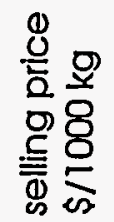

요

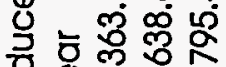

d

응ํㅇㅇㅀ

ह도

엉용

D

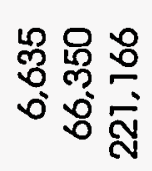

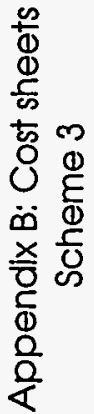

음

突放

웅요

d 숑

공ํㅇ

음 出

꼬 엉

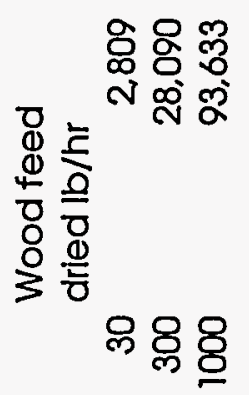

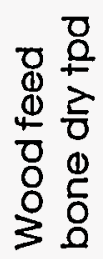


Appendix C: $\quad$ Process Stream Summary 


\begin{tabular}{|c|c|c|c|c|c|c|c|c|}
\hline $\begin{array}{l}\text { Stream name } \\
\text { From block: } \\
\text { To block } \\
\text { Mole Flow KMOL/HR }\end{array}$ & $\begin{array}{r}145 \\
\text { PUMP1 } \\
\text { B6 }\end{array}$ & $\begin{array}{r}160 \\
\text { PUMP4 } \\
\text { INTER2A }\end{array}$ & $\begin{array}{r}165 \\
\text { PUMP5 } \\
\text { INTER2B }\end{array}$ & $\begin{array}{r}188 \\
B 13 \\
\text { STMGEN6 }\end{array}$ & $\begin{array}{r}189 \\
\text { PSACOOL }\end{array}$ & $\begin{array}{r}196 \\
B 3 \\
\text { LTCOOL }\end{array}$ & $\begin{array}{r}205 \\
\text { SYNCOMPR } \\
\text { B2 }\end{array}$ & $\begin{array}{r}207 \\
\text { B2 } \\
\text { REFHTR }\end{array}$ \\
\hline TAR & 0.0 & 0.0 & 0.0 & 0.0 & 0.0 & 0.0 & 3.3 & 4.6 \\
\hline $\mathrm{H} 2$ & 0.0 & 0.0 & 0.0 & 0.0 & 0.0 & 0.0 & 0.0 & 244.1 \\
\hline $\mathrm{O} 2$ & 0.0 & 0.0 & 0.0 & 0.0 & 0.0 & 0.0 & 0.0 & 0.0 \\
\hline N2 & 0.0 & 0.0 & 0.0 & 0.0 & 0.0 & 0.0 & 0.0 & 0.0 \\
\hline $\mathrm{CO} 2$ & 0.0 & 0.0 & 0.0 & 0.0 & 0.0 & 0.0 & 0.0 & 154.7 \\
\hline co & 0.0 & 0.0 & 0.0 & 0.0 & 0.0 & 0.0 & 0.0 & 496.2 \\
\hline $\mathrm{H} 2 \mathrm{O}$ & 1886.0 & 133.2 & 113.7 & 891.1 & 1519.3 & 669.1 & 0.0 & 1202.3 \\
\hline $\mathrm{CH} 4$ & 0.0 & 0.0 & 0.0 & 0.0 & .0 .0 & 0.0 & 0.0 & 181.9 \\
\hline H2S & 0.0 & 0.0 & 0.0 & 0.0 & 0.0 & 0.0 & 0.0 & 1.0 \\
\hline $\mathrm{NH3}$ & 0.0 & 0.0 & 0.0 & 0.0 & 0.0 & 0.0 & 0.0 & 4.3 \\
\hline $\cos$ & 0.0 & 0.0 & 0.0 & 0.0 & 0.0 & 0.0 & 0.0 & 0.0 \\
\hline SO2 & 0.0 & 0.0 & 0.0 & 0.0 & 0.0 & 0.0 & 0.0 & 0.0 \\
\hline SO3 & 0.0 & 0.0 & 0.0 & 0.0 & 0.0 & 0.0 & 0.0 & 0.0 \\
\hline NO2 & 0.0 & 0.0 & 0.0 & 0.0 & 0.0 & 0.0 & 0.0 & 0.0 \\
\hline NO & 0.0 & 0.0 & 0.0 & 0.0 & 0.0 & 0.0 & 0.0 & 0.0 \\
\hline PHENOL & 0.0 & 0.0 & 0.0 & 0.0 & 0.0 & 0.0 & 0.0 & 0.0 \\
\hline $\mathrm{C} 6 \mathrm{H} 6$ & 0.0 & 0.0 & 0.0 & 0.0 & 0.0 & 0.0 & 0.0 & 0.0 \\
\hline $\mathrm{C} 2 \mathrm{H}_{6}$ & 0.0 & 0.0 & 0.0 & 0.0 & 0.0 & 0.0 & 0.0 & 5.3 \\
\hline $\mathrm{C} 2 \mathrm{H}_{4}$ & 0.0 & 0.0 & 0.0 & 0.0 & 0.0 & 0.0 & 0.0 & 53.1 \\
\hline $\mathrm{C} 2 \mathrm{H} 2$ & 0.0 & 0.0 & 0.0 & 0.0 & 0.0 & 0.0 & 0.0 & 4.1 \\
\hline $\mathrm{O} 2 \mathrm{SI}$ & 0.0 & 0.0 & 0.0 & 0.0 & 0.0 & 0.0 & 0.0 & 0.0 \\
\hline CARBON & 0.0 & 0.0 & 0.0 & 0.0 & 0.0 & 0.0 & 0.0 & 0.0 \\
\hline
\end{tabular}




\begin{tabular}{|c|c|c|c|c|c|c|c|c|}
\hline $0^{\circ} 0$ & $0^{\circ} 0$ & 0.0 & 0.0 & 0.0 & 0.0 & 0.0 & 0.0 & NOG $\forall \forall O$ \\
\hline $0^{\circ} 0$ & $0^{\circ} 0$ & $0^{\circ} 0$ & 0.0 & $6.08 \angle 0 \mathrm{~L}$ & 0.0 & $0^{\circ} 0$ & 0.0 & 1520 \\
\hline $0^{\circ} 0$ & $0^{\circ} 0$ & $0^{\circ} 0$ & 0.0 & 0.0 & 0.0 & 0.0 & 0.0 & ZHZO \\
\hline $0^{\circ} 0$ & 0.0 & $0^{\circ} 0$ & 0.0 & 00 & $0 \%$ & 0.0 & $0 \%$ & $\mathrm{DHZO}$ \\
\hline 0.0 & 0.0 & 0.0 & 0.0 & 0.0 & 0.0 & 0.0 & 0.0 & 9HZO \\
\hline $0^{\circ} 0$ & 0.0 & 0.0 & $0 \%$ & $0 \%$ & 0.0 & $0^{\circ} 0$ & 0.0 & $9 \mathrm{H} 9 \mathrm{O}$ \\
\hline $0^{\circ} 0$ & 0.0 & 0.0 & 0.0 & 00 & 0.0 & 0.0 & 0.0 & TON $\mathrm{Hd}$ \\
\hline $0^{\circ} 0$ & 0.0 & 00 & 0.0 & 00 & 0.0 & 0.0 & 0.0 & ON \\
\hline 0.0 & 0.0 & 0.0 & 0.0 & 0.0 & 0.0 & $0^{\circ} 0$ & 0.0 & ZON \\
\hline $0^{\circ} 0$ & 0.0 & 0.0 & $0^{\circ} 0$ & $0^{\circ} 0$ & 0.0 & 0.0 & 0.0 & EOS \\
\hline $0^{\circ} 0$ & $0^{\circ} 0$ & $0^{\circ} 0$ & 0.0 & 0.0 & 0.0 & 0.0 & 0.0 & zos \\
\hline $0^{\circ} 0$ & 0.0 & $0^{\circ} 0$ & 0.0 & 0.0 & 0.0 & 0.0 & 0.0 & soo \\
\hline 0.0 & 0.0 & $0^{\circ} 0$ & 0.0 & 0.0 & 0.0 & 0.0 & 0.0 & $E H N$ \\
\hline $0^{\circ} 0$ & 0.0 & 0.0 & 0.0 & 0.0 & 0.0 & 0.0 & 0.0 & $\mathrm{SzH}$ \\
\hline 0.0 & 0.0 & 0.0 & 0.0 & 0.0 & 0.0 & 0.0 & 0.0 & $\mathrm{DHO}$ \\
\hline$\vdash \vdash 68$ & LELL & 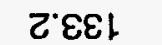 & 0.9881 & 0.0 & 6.8881 & $9 \angle L L L$ & $\varepsilon$ ¿0टł & $\mathrm{OZH}$ \\
\hline 00 & 0.0 & 0.0 & 0.0 & 0.0 & 0.0 & 0.0 & 0.0 & 00 \\
\hline 0.0 & 0.0 & $0^{\circ} 0$ & 0.0 & 0.0 & 0.0 & $0^{\circ} 0$ & $0^{\circ} 0$ & 200 \\
\hline $0^{\circ} 0$ & 0.0 & 0.0 & 0.0 & 0.0 & 0.0 & 0.0 & 0.0 & $Z N$ \\
\hline 0.0 & $0^{\circ} 0$ & 0.0 & 0.0 & 0.0 & 0.0 & $0^{\prime} 0$ & 0.0 & 20 \\
\hline 0.0 & 0.0 & $0^{\circ} 0$ & 0.0 & 0.0 & 0.0 & 0.0 & $0^{\circ} 0$ & $\mathrm{ZH}$ \\
\hline $0^{\circ} 0$ & 0.0 & $0^{\circ} 0$ & 0.0 & 0.0 & $0^{\circ} 0$ & 0.0 & $0^{\circ} 0$ & 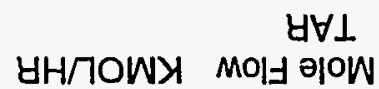 \\
\hline Eเg & SdWnd & tdWnd & LdWnd & $\begin{array}{l}\text { 17dSaN甘S } \\
\text { 17dSgWOO }\end{array}$ & $d \exists S a O O M$ & $\begin{array}{l}7000 \forall S d \\
\angle 8\end{array}$ & zg & 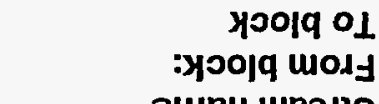 \\
\hline$b M \pm 8$ & gZM」B & $\forall Z M J 9$ & $\forall L M J 8$ & ONVSHSV & GOOMYV & ZIZ & $80 Z$ & өureu meө.ts \\
\hline
\end{tabular}




\begin{tabular}{|c|c|c|c|c|c|c|c|c|}
\hline $\begin{array}{l}\text { Stream name } \\
\text { From block: } \\
\text { To block } \\
\text { Mole Flow KMOL/HR }\end{array}$ & BFW5 & B3 & $\begin{array}{r}\text { CHAR } \\
\text { CHARSEP } \\
\text { CHARDEC }\end{array}$ & $\begin{array}{r}\text { CHARCOMP } \\
\text { CHARDEC } \\
\text { CHARFURN }\end{array}$ & $\begin{array}{r}\text { CHARFLUE } \\
\text { COMBSPLT } \\
\text { DRYRMIX }\end{array}$ & MODEL2 & $\begin{array}{r}\text { CO } \\
\text { MODEL2 }\end{array}$ & $\begin{array}{l}\text { COLDIN } \\
\text { MODEL1 }\end{array}$ \\
\hline TAR & 0.0 & 0.0 & 0.0 & 0.0 & 0.0 & 0.0 & 0.0 & 4.6 \\
\hline $\mathrm{H} 2$ & 0.0 & 0.0 & 0.0 & 165.6 & 0.0 & 0.0 & 0.0 & 252.8 \\
\hline $\mathrm{O} 2$ & 0.0 & 0.0 & 0.0 & 92.1 & 228.2 & 0.0 & 0.0 & 0.0 \\
\hline N2 & 0.0 & 0.0 & 0.0 & 0.2 & 3080.9 & 0.0 & 0.0 & 0.0 \\
\hline $\mathrm{CO} 2$ & 0.0 & 0.0 & 0.0 & 0.0 & 599.0 & 0.0 & 0.0 & 154.4 \\
\hline CO & 0.0 & 0.0 & 0.0 & 0.0 & 0.0 & 0.0 & 0.0 & 495.8 \\
\hline $\mathrm{H} 2 \mathrm{O}$ & 1777.6 & 669.1 & 0.0 & 0.0 & 205.6 & 1343.8 & 1343.8 & 1202.3 \\
\hline $\mathrm{CH} 4$ & 0.0 & 0.0 & 0.0 & 0.0 & 0.0 & 0.0 & 0.0 & 182.7 \\
\hline H2S & 0.0 & 0.0 & 0.0 & 0.0 & 0.0 & 0.0 & 0.0 & 1.2 \\
\hline $\mathrm{NH3}$ & 0.0 & 0.0 & 0.0 & 0.0 & 0.0 & 0.0 & 0.0 & 5.0 \\
\hline $\cos$ & 0.0 & 0.0 & 0.0 & 0.0 & 0.0 & 0.0 & 0.0 & 0.0 \\
\hline SO2 & 0.0 & 0.0 & 0.0 & 0.0 & 0.1 & 0.0 & 0.0 & 0.0 \\
\hline $\mathrm{SO3}$ & 0.0 & 0.0 & 0.0 & 0.0 & 0.0 & 0.0 & 0.0 & 0.0 \\
\hline NO2 & 0.0 & 0.0 & 0.0 & 0.0 & 0.0 & 0.0 & 0.0 & 0.0 \\
\hline NO & 0.0 & 0.0 & 0.0 & 0.0 & 0.0 & 0.0 & 0.0 & 0.0 \\
\hline PHENOL & 0.0 & 0.0 & 0.0 & 0.0 & 0.0 & 0.0 & 0.0 & 0.0 \\
\hline $\mathrm{C} 6 \mathrm{H} 6$ & 0.0 & 0.0 & 0.0 & 0.0 & 0.0 & 0.0 & 0.0 & 0.0 \\
\hline $\mathrm{C} 2 \mathrm{H} 6$ & 0.0 & 0.0 & 0.0 & 0.0 & 0.0 & 0.0 & 0.0 & 5.7 \\
\hline $\mathrm{C} 2 \mathrm{H} 4$ & 0.0 & 0.0 & 0.0 & 0.0 & 0.0 & 0.0 & 0.0 & 53.0 \\
\hline $\mathrm{C} 2 \mathrm{H} 2$ & 0.0 & 0.0 & 0.0 & 0.0 & 0.0 & 0.0 & 0.0 & 4.9 \\
\hline O2SI & 0.0 & 0.0 & 10727.4 & 10727.4 & 0.0 & 0.0 & 0.0 & 0.0 \\
\hline CARBON & 0.0 & 0.0 & 0.0 & 597.7 & 0.0 & 0.0 & 0.0 & 0.0 \\
\hline
\end{tabular}




Stream name
From block:
To block
Mole Flow KMOL/HR
TAR
H2
O2
N2
CO2
CO
H2O
CH4
H2S
NH3
COS
SO2
SO3
NO2
NO
PHENOL
C6H6
C2H6
C2H4
C2H2
O2SI
CARBON

COLDOUT
MODEL1

4.6
252.8
0.0
0.0
154.4
495.8
1202.3
182.7
1.2
5.0
0.0
0.0
0.0
0.0
0.0
0.0
0.0
5.7
53.0
4.9
0.0
0.0

\section{COMBAIR \\ AIRCOMP1}

0.0
0.0
816.6
3080.8
1.3
0.0
40.0
0.0
0.0
0.0
0.0
0.0
0.0
0.0
0.0
0.0
0.0
0.0
0.0
0.0
0.0
0.0

COMBAIR2 AIRCOMP1 AIRHEAT

COMBPROD CHARFURN COMBSPLT

$\begin{array}{rr}0.0 & 0.0 \\ 0.0 & 0.0 \\ 816.6 & 228.2 \\ 3080.8 & 3080.9 \\ 1.3 & 599.0 \\ 0.0 & 0.0 \\ 40.0 & 205.6 \\ 0.0 & 0.0 \\ 0.0 & 0.0 \\ 0.0 & 0.0 \\ 0.0 & 0.0 \\ 0.0 & 0.1 \\ 0.0 & 0.0 \\ 0.0 & 0.0 \\ 0.0 & 0.0 \\ 0.0 & 0.0 \\ 0.0 & 0.0 \\ 0.0 & 0.0 \\ 0.0 & 0.0 \\ 0.0 & 0.0 \\ 0.0 & 10780.9 \\ 0.0 & 0.0\end{array}$

COOLED2A B4 INTER2A INTER2A

4.6
244.1
0.0
0.0
154.7
496.2
1202.3
181.9
1.0
4.3
0.0
0.0
0.0
0.0
0.0
0.0
0.0
5.3
53.1
4.1
0.0
0.0

0.0
0.0
332.6
1254.6
0.5
0.0
16.3
0.0
0.0
0.0
0.0
0.0
0.0
0.0
0.0
0.0
0.0
0.0
0.0
0.0
0.0
0.0

COOLED2B INTER2B

0.0
0.0
332.6
1254.6
0.5
0.0
16.3
0.0
0.0
0.0
0.0
0.0
0.0
0.0
0.0
0.0
0.0
0.0
0.0
0.0
0.0
0.0

DRIED DRYRSEP

0.0
0.0
0.0
0.0
0.0
0.0
0.0
0.0
0.0
0.0
0.0
0.0
0.0
0.0
0.0
0.0
0.0
0.0
0.0
0.0
0.0
0.0




Stream name
From block:
To block
Mole Flow KMOL/HR
TAR
H2
O2
N2
CO2
CO
H2O
CH4
H2S
NH3
COS
SO2
SO3
NO2
NO
PHENOL
C6H6
C2H6
C2H4
C2H2
O2SI
CARBON

$\begin{array}{rr}\text { DRYRAIR } & \begin{array}{r}\text { DRYRAIR2 } \\ \text { AIRCOMP2 } \\ \text { DRYRMIX }\end{array} \\ \text { AIRCOMP2 } & \\ & 0.0 \\ 0.0 & 0.0 \\ 0.0 & 4705.0 \\ 4705.0 & 17749.5 \\ 17749.5 & 7.5 \\ 7.5 & 0.0 \\ 0.0 & 230.3 \\ 230.3 & 0.0 \\ 0.0 & 0.0 \\ 0.0 & 0.0 \\ 0.0 & 0.0 \\ 0.0 & 0.0 \\ 0.0 & 0.0 \\ 0.0 & 0.0 \\ 0.0 & 0.0 \\ 0.0 & 0.0 \\ 0.0 & 0.0 \\ 0.0 & 0.0 \\ 0.0 & 0.0 \\ 0.0 & 0.0 \\ 0.0 & 0.0 \\ 0.0 & 0.0 \\ 0.0 & \end{array}$

$\begin{array}{rr}\text { DRYWOOD } & \text { FLUENAIR } \\ \text { DRY2 } & \text { DRYRMIX } \\ \text { DRYRSEP } & \text { DRY1 }\end{array}$

FROMHT
HTSHIFT
LTCOOL

$\begin{array}{rr}\text { FROMLT } & \text { FROMPRIM } \\ \text { LTSHIFT } & \text { GSTMGEN } \\ \text { PSACOOL } & \text { HTCOOL }\end{array}$

GAS1A

0.0
0.0
4933.3

0.0
0.0
4933.3
20830.4
606.4
0.0
435.9
0.0
0.0
0.0
0.0
0.1
0.0
0.0
0.0
0.0
0.0
0.0
0.0
0.0
0.0
0.0

0.0
1546.0
0.0
2.1
812.7
116.4
1610.4
74.5
1.0
0.2
0.0
0.0
0.0
0.0
0.0
0.0
0.0
0.0
0.0
0.0
0.0
0.0

0.0
1633.2
0.0
2.1
900.0
29.1
1523.1
74.5
1.0
0.2
0.0
0.0
0.0
0.0
0.0
0.0
0.0
0.0
0.0
0.0
0.0
0.0

0.0
1274.4
0.0
2.1
541.2
387.9
1881.9
74.5
1.0
0.2
0.0
0.0
0.0
0.0
0.0
0.0
0.0
0.0
0.0
0.0
0.0
0.0

B4

20830.4
606.4

0.0

2274.8

0.0
0.0

0.0

0.0

0.1
0.0

0.0

0.0

0.0

0.0

0.0

0.0

0.0

0.0

0.0

4.6
244.1
0.0
0.0
154.7
496.2
102.3
181.9
1.0
4.3
0.0
0.0
0.0
0.0
0.0
0.0
0.0
5.3
53.1
4.1
0.0
0.0




\begin{tabular}{|c|c|c|c|c|c|c|c|c|}
\hline $\begin{array}{l}\text { Stream name } \\
\text { From block: } \\
\text { To block } \\
\text { Mole Flow KMOL/HR }\end{array}$ & $\begin{array}{l}\text { GAS2A } \\
\text { INTER2A }\end{array}$ & $\begin{array}{r}\text { GAS2B } \\
\text { INTER2B }\end{array}$ & $\begin{array}{r}\text { GASIFSTM } \\
\text { GSTMGEN } \\
\text { FEEDMIX }\end{array}$ & $\begin{array}{c}\text { GASWAT } \\
\text { DRYRSEP }\end{array}$ & $\begin{array}{r}\text { GFEED } \\
\text { FEEDMIX } \\
\text { GASIFIER }\end{array}$ & $\begin{array}{l}\text { GSTMIN } \\
\text { GSTMGEN }\end{array}$ & $\begin{array}{r}\text { H2PROD } \\
\text { RECSPLT }\end{array}$ & $\begin{array}{r}\text { H2PURIFY } \\
\text { PSA } \\
\text { RECSPLT }\end{array}$ \\
\hline TAR & 0.0 & 0.0 & 0.0 & 0.0 & 0.0 & 0.0 & 0.0 & 0.0 \\
\hline $\mathrm{H} 2$ & 0.0 & 0.0 & 0.0 & 0.0 & 0.0 & 0.0 & 1268.4 & 2067.2 \\
\hline $\mathrm{O} 2$ & 332.6 & 332.6 & 0.0 & 4933.3 & 0.0 & 0.0 & 0.0 & 0.0 \\
\hline N2 & 1254.6 & 1254.6 & 0.0 & 20830.4 & 0.0 & 0.0 & 0.0 & 0.0 \\
\hline $\mathrm{CO} 2$ & 0.5 & 0.5 & 0.0 & 606.4 & 0.0 & 0.0 & 0.0 & 0.0 \\
\hline CO & 0.0 & 0.0 & 0.0 & 0.0 & 0.0 & 0.0 & 0.0 & 0.0 \\
\hline $\mathrm{H} 2 \mathrm{O}$ & 16.3 & 16.3 & 943.0 & 2274.8 & 943.0 & 943.0 & 0.0 & 0.0 \\
\hline $\mathrm{CH} 4$ & 0.0 & 0.0 & 0.0 & 0.0 & 0.0 & 0.0 & 0.0 & 0.0 \\
\hline $\mathrm{H} 2 \mathrm{~S}$ & 0.0 & 0.0 & 0.0 & 0.0 & 0.0 & 0.0 & 0.0 & 0.0 \\
\hline $\mathrm{NH3}$ & 0.0 & 0.0 & 0.0 & 0.0 & 0.0 & 0.0 & 0.0 & 0.0 \\
\hline $\cos$ & 0.0 & 0.0 & 0.0 & 0.0 & 0.0 & 0.0 & 0.0 & 0.0 \\
\hline $\mathrm{SO} 2$ & 0.0 & 0.0 & 0.0 & 0.1 & 0.0 & 0.0 & 0.0 & 0.0 \\
\hline SO3 & 0.0 & 0.0 & 0.0 & 0.0 & 0.0 & 0.0 & 0.0 & 0.0 \\
\hline NO2 & 0.0 & 0.0 & 0.0 & 0.0 & 0.0 & 0.0 & 0.0 & 0.0 \\
\hline NO & 0.0 & 0.0 & 0.0 & 0.0 & 0.0 & 0.0 & 0.0 & 0.0 \\
\hline PHENOL & 0.0 & 0.0 & 0.0 & 0.0 & 0.0 & 0.0 & 0.0 & 0.0 \\
\hline $\mathrm{C} 6 \mathrm{H} 6$ & 0.0 & 0.0 & 0.0 & 0.0 & 0.0 & 0.0 & 0.0 & 0.0 \\
\hline $\mathrm{C} 2 \mathrm{H} 6$ & 0.0 & 0.0 & 0.0 & 0.0 & 0.0 & 0.0 & 0.0 & 0.0 \\
\hline $\mathrm{C} 2 \mathrm{H} 4$ & 0.0 & 0.0 & 0.0 & 0.0 & 0.0 & 0.0 & 0.0 & 0.0 \\
\hline $\mathrm{C} 2 \mathrm{H} 2$ & 0.0 & 0.0 & 0.0 & 0.0 & 0.0 & 0.0 & 0.0 & 0.0 \\
\hline $\mathrm{O} 2 \mathrm{SI}$ & 0.0 & 0.0 & 0.0 & 0.0 & 10727.4 & 0.0 & 0.0 & 0.0 \\
\hline CARBON & 0.0 & 0.0 & 0.0 & 0.0 & 0.0 & 0.0 & 0.0 & 0.0 \\
\hline
\end{tabular}




\begin{tabular}{|c|c|c|c|c|c|c|c|c|}
\hline $\begin{array}{l}\text { Stream name } \\
\text { From block: } \\
\text { To block } \\
\text { Mole Flow KMOLHR }\end{array}$ & $\begin{array}{r}\text { H2RECYCL } \\
\text { RECSPLT } \\
\text { RECMIX }\end{array}$ & $\begin{array}{r}\text { HCOMBAIR } \\
\text { AIRHEAT } \\
\text { CHARFURN }\end{array}$ & MODEL2 & $\begin{array}{r}\text { HO } \\
\text { MODEL2 }\end{array}$ & $\begin{array}{r}\text { HOTIN } \\
\text { MODELI }\end{array}$ & $\begin{array}{l}\text { HOTOUT } \\
\text { MODEL1 }\end{array}$ & $\begin{array}{r}\text { KOWATER } \\
\text { B1 } \\
\text { B5 }\end{array}$ & $\begin{array}{r}\text { MIDWOOD } \\
\text { WOODSEP } \\
\text { DRY2 }\end{array}$ \\
\hline TAR & 0.0 & 0.0 & 0.0 & 0.0 & 4.6 & 4.6 & 0.0 & 0.0 \\
\hline $\mathrm{H} 2$ & 798.8 & 0.0 & 0.0 & 0.0 & 252.8 & 252.8 & 0.0 & 0.0 \\
\hline $\mathrm{O} 2$ & 0.0 & 816.6 & 50.4 & 50.4 & 0.0 & 0.0 & 0.0 & 0.0 \\
\hline N2 & 0.0 & 3080.8 & 1500.9 & 1500.9 & 0.0 & 0.0 & 0.0 & 0.0 \\
\hline $\mathrm{CO} 2$ & 0.0 & 1.3 & 1004.6 & 1004.6 & 154.4 & 154.4 & 0.0 & 0.0 \\
\hline CO & 0.0 & 0.0 & 0.0 & 0.0 & 495.8 & 495.8 & 0.0 & 0.0 \\
\hline $\mathrm{H} 2 \mathrm{O}$ & 0.0 & 40.0 & 535.1 & 535.1 & 1202.3 & 1202.3 & 1202.3 & 0.0 \\
\hline $\mathrm{CH} 4$ & 0.0 & 0.0 & 0.0 & 0.0 & 182.7 & 182.7 & 0.0 & 0.0 \\
\hline H2S & 0.0 & 0.0 & 0.0 & 0.0 & 1.2 & 1.2 & 0.0 & 0.0 \\
\hline $\mathrm{NH3}$ & 0.0 & 0.0 & 0.0 & 0.0 & 5.0 & 5.0 & 0.0 & 0.0 \\
\hline cos & 0.0 & 0.0 & 0.0 & 0.0 & 0.0 & 0.0 & 0.0 & 0.0 \\
\hline SO2 & 0.0 & 0.0 & 0.0 & 0.0 & 0.0 & 0.0 & 0.0 & 0.0 \\
\hline SO3 & 0.0 & 0.0 & 0.0 & 0.0 & 0.0 & 0.0 & 0.0 & 0.0 \\
\hline NO2 & 0.0 & 0.0 & 0.0 & 0.0 & 0.0 & 0.0 & 0.0 & 0.0 \\
\hline NO & 0.0 & 0.0 & 0.0 & 0.0 & 0.0 & 0.0 & 0.0 & 0.0 \\
\hline PHENOL & 0.0 & 0.0 & 0.0 & 0.0 & 0.0 & 0.0 & 0.0 & 0.0 \\
\hline $\mathrm{C} 6 \mathrm{H} 6$ & 0.0 & 0.0 & 0.0 & 0.0 & 0.0 & 0.0 & 0.0 & 0.0 \\
\hline $\mathrm{C} 2 \mathrm{H} 6$ & 0.0 & 0.0 & 0.0 & 0.0 & 5.7 & 5.7 & 0.0 & 0.0 \\
\hline $\mathrm{C} 2 \mathrm{H} 4$ & 0.0 & 0.0 & 0.0 & 0.0 & 53.0 & 53.0 & 0.0 & 0.0 \\
\hline $\mathrm{C} 2 \mathrm{H} 2$ & 0.0 & 0.0 & 0.0 & 0.0 & 4.9 & 4.9 & 0.0 & 0.0 \\
\hline O2SI & 0.0 & 0.0 & 0.0 & 0.0 & 0.0 & 0.0 & 0.0 & 0.0 \\
\hline CARBON & 0.0 & 0.0 & 0.0 & 0.0 & 0.0 & 0.0 & 0.0 & 0.0 \\
\hline
\end{tabular}




\begin{tabular}{|c|c|c|c|c|c|c|c|c|}
\hline $\begin{array}{l}\text { Stream name } \\
\text { From block: } \\
\text { To block } \\
\text { Mole Flow KMOL/HR }\end{array}$ & $\begin{array}{r}\text { OFFAIR1 } \\
\text { OFFCOMPR }\end{array}$ & $\begin{array}{r}\text { OFFAIR2 } \\
\text { OFFCOMPR } \\
\text { OFFCOMB }\end{array}$ & $\begin{array}{r}\text { OFFFLUE1 } \\
\text { OFFCOMB } \\
\text { COMBCOOL }\end{array}$ & $\begin{array}{r}\text { OFFFLUE2 } \\
\text { COMBCOOL } \\
\text { STMGEN6 }\end{array}$ & $\begin{array}{r}\text { OFFFLUE3 } \\
\text { STMGEN6 }\end{array}$ & $\begin{array}{r}\text { OFFGAS } \\
\text { PSA } \\
\text { OFFCOMB }\end{array}$ & $\begin{array}{c}\text { REFSTM } \\
\text { REFSTM } \\
\text { PRIMARY }\end{array}$ & $\begin{array}{l}\text { REFSTMA } \\
\text { WATPUMP }\end{array}$ \\
\hline TAR & 0.0 & 0.0 & 0.0 & 0.0 & 0.0 & 0.0 & 0.0 & 0.0 \\
\hline $\mathrm{H} 2$ & 0.0 & 0.0 & 0.0 & 0.0 & 0.0 & 364.8 & 0.0 & 0.0 \\
\hline $\mathrm{O} 2$ & 397.8 & 397.8 & 50.2 & 50.2 & 50.2 & 0.0 & 0.0 & 0.0 \\
\hline N2 & 1500.6 & 1500.6 & 1502.6 & 1502.6 & 1502.6 & 2.1 & 0.0 & 0.0 \\
\hline $\mathrm{CO} 2$ & 0.6 & 0.6 & 1004.2 & 1004.2 & 1004.2 & 900.0 & 0.0 & 0.0 \\
\hline $\mathrm{CO}$ & 0.0 & 0.0 & 0.0 & 0.0 & 0.0 & 29.1 & 0.0 & 0.0 \\
\hline $\mathrm{H} 2 \mathrm{O}$ & 19.5 & 19.5 & 538.2 & 538.2 & 538.2 & 3.8 & 1344.4 & 1344.4 \\
\hline $\mathrm{CH} 4$ & 0.0 & 0.0 & 0.0 & 0.0 & 0.0 & 74.5 & 0.0 & 0.0 \\
\hline H2S & 0.0 & 0.0 & 0.0 & 0.0 & 0.0 & 1.0 & 0.0 & 0.0 \\
\hline $\mathrm{NH} 3$ & 0.0 & 0.0 & 0.0 & 0.0 & 0.0 & 0.2 & 0.0 & 0.0 \\
\hline $\cos$ & 0.0 & 0.0 & 0.0 & 0.0 & 0.0 & 0.0 & 0.0 & 0.0 \\
\hline SO2 & 0.0 & 0.0 & 0.9 & 0.9 & 0.9 & 0.0 & 0.0 & 0.0 \\
\hline $\mathrm{SO3}$ & 0.0 & 0.0 & 0.1 & 0.1 & 0.1 & 0.0 & 0.0 & 0.0 \\
\hline NO2 & 0.0 & 0.0 & 0.0 & 0.0 & 0.0 & 0.0 & 0.0 & 0.0 \\
\hline NO & 0.0 & 0.0 & 0.2 & 0.2 & 0.2 & 0.0 & 0.0 & 0.0 \\
\hline PHENOL & 0.0 & 0.0 & 0.0 & 0.0 & 0.0 & 0.0 & 0.0 & 0.0 \\
\hline $\mathrm{C} 6 \mathrm{H} 6$ & 0.0 & 0.0 & 0.0 & 0.0 & 0.0 & 0.0 & 0.0 & 0.0 \\
\hline $\mathrm{C} 2 \mathrm{H} 6$ & 0.0 & 0.0 & 0.0 & 0.0 & 0.0 & 0.0 & 0.0 & 0.0 \\
\hline $\mathrm{C} 2 \mathrm{H} 4$ & 0.0 & 0.0 & 0.0 & 0.0 & 0.0 & 0.0 & 0.0 & 0.0 \\
\hline $\mathrm{C} 2 \mathrm{H} 2$ & 0.0 & 0.0 & 0.0 & 0.0 & 0.0 & 0.0 & 0.0 & 0.0 \\
\hline O2SI & 0.0 & 0.0 & 0.0 & 0.0 & 0.0 & 0.0 & 0.0 & 0.0 \\
\hline CARBON & 0.0 & 0.0 & 0.0 & 0.0 & 0.0 & 0.0 & 0.0 & 0.0 \\
\hline
\end{tabular}

Appendix C: Cost sheets 


Stream name
From block:
To block
Mole Flow KMOLHR
TAR
H2
O2
N2
CO2
CO
H2O
CH4
H2S
NH3
COS
SO2
SO3
NO2
NO
PHENOL
C6H6
C2H6
C2H4
C2H2
O2SI
CARBON

$\begin{array}{rr}\text { REFSTMB } & \begin{array}{r}\text { SAND } \\ \text { WATPUMP }\end{array} \\ \text { REFSTM } & \text { SANDSPLT } \\ & \\ 0.0 & 0.0 \\ 0.0 & 0.0 \\ 0.0 & 0.0 \\ 0.0 & 0.0 \\ 0.0 & 0.0 \\ 0.0 & 0.0 \\ 1344.4 & 0.0 \\ 0.0 & 0.0 \\ 0.0 & 0.0 \\ 0.0 & 0.0 \\ 0.0 & 0.0 \\ 0.0 & 0.0 \\ 0.0 & 0.0 \\ 0.0 & 0.0 \\ 0.0 & 0.0 \\ 0.0 & 0.0 \\ 0.0 & 0.0 \\ 0.0 & 0.0 \\ 0.0 & 0.0 \\ 0.0 & 0.0 \\ 0.0 & 10727.4 \\ 0.0 & 0.0\end{array}$

$\begin{array}{llr}\text { SANDPURG } & \text { SANDSUPP } & \text { STEAM1A } \\ \text { SANDSPLT } & & \text { STMFLASH } \\ & \text { CHARFURN } & \end{array}$

STEAM2A INTER2A

STEAM2B INTER2B

STEAM4 STMGEN6

0.0
0.0
0.0
0.0
0.0
0.0
0.0
0.0
0.0
0.0
0.0
0.0
0.0
0.0
0.0
0.0
0.0
0.0
0.0
0.0
53.9
0.0

0.0
0.0
0.0
0.0
0.0
0.0
0.0
0.0
0.0
0.0
0.0
0.0
0.0
0.0
0.0
0.0
0.0
0.0
0.0
0.0
53.5
0.0

0.0
0.0
0.0
0.0
0.0
0.0
884.3
0.0
0.0
0.0
0.0
0.0
0.0
0.0
0.0
0.0
0.0
0.0
0.0
0.0
0.0
0.0

0.0
0.0
0.0
0.0
0.0
0.0
133.2
0.0
0.0
0.0
0.0
0.0
0.0
0.0
0.0
0.0
0.0
0.0
0.0
0.0
0.0
0.0

0.0

0.0

0.0

0.0

0.0

0.0

113.7

0.0

0.0

0.0

0.0

0.0

0.0

0.0

0.0

0.0

0.0

0.0

0.0

0.0

0.0

0.0

0.0
0.0
0.0
0.0
0.0
0.0
891.1
0.0
0.0
0.0
0.0
0.0
0.0
0.0
0.0
0.0
0.0
0.0
0.0
0.0
0.0
0.0 


$\begin{array}{lrr}\begin{array}{l}\text { Stream name } \\ \text { From block: } \\ \text { To block } \\ \text { Mole Flow KMOL/HR }\end{array} & \begin{array}{r}\text { STEAM5 } \\ \text { PSACOOL }\end{array} & \begin{array}{r}\text { STEAM6 } \\ \text { LTCOOL }\end{array} \\ \text { TAR } & & \\ \text { H2 } & 0.0 & 0.0 \\ \text { O2 } & 0.0 & 0.0 \\ \text { N2 } & 0.0 & 0.0 \\ \text { CO2 } & 0.0 & 0.0 \\ \text { CO } & 0.0 & 0.0 \\ \text { H2O } & 0.0 & 0.0 \\ \text { CH4 } & 1777.6 & 669.1 \\ \text { H2S } & 0.0 & 0.0 \\ \text { NH3 } & 0.0 & 0.0 \\ \text { COS } & 0.0 & 0.0 \\ \text { SO2 } & 0.0 & 0.0 \\ \text { SO3 } & 0.0 & 0.0 \\ \text { NO2 } & 0.0 & 0.0 \\ \text { NO } & 0.0 & 0.0 \\ \text { PHENOL } & 0.0 & 0.0 \\ \text { C6H6 } & 0.0 & 0.0 \\ \text { C2H6 } & 0.0 & 0.0 \\ \text { C2H4 } & 0.0 & 0.0 \\ \text { C2H2 } & 0.0 & 0.0 \\ \text { O2SI } & 0.0 & 0.0 \\ \text { CARBON } & 0.0 & 0.0 \\ \text { L } & 0.0 & 0.0\end{array}$

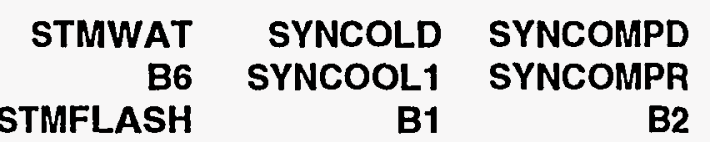

CHARSEP SYNCOOL1

1.2
244.1
0.0
0.0
154.7
496.2
0.0
181.9
1.0
4.3
0.0
0.0
0.0
0.0
0.0
0.0
0.0
5.3
53.1
4.1
0.0
0.0

SYNGAS

SYNREFRM TOCOMPR

PRIMARY GSTMGEN SYNCOMPR

$\begin{array}{rrr}4.6 & 0.0 & 4.6 \\ 244.1 & 1274.4 & 244.1 \\ 0.0 & 0.0 & 0.0 \\ 0.0 & 2.1 & 0.0 \\ 154.7 & 541.2 & 154.7 \\ 496.2 & 387.9 & 496.2 \\ 1202.3 & 1881.9 & 0.0 \\ 181.9 & 74.5 & 181.9 \\ 1.0 & 1.0 & 1.0 \\ 4.3 & 0.2 & 4.3 \\ 0.0 & 0.0 & 0.0 \\ 0.0 & 0.0 & 0.0 \\ 0.0 & 0.0 & 0.0 \\ 0.0 & 0.0 & 0.0 \\ 0.0 & 0.0 & 0.0 \\ 0.0 & 0.0 & 0.0 \\ 0.0 & 0.0 & 0.0 \\ 5.3 & 0.0 & 5.3 \\ 53.1 & 0.0 & 53.1 \\ 4.1 & 0.0 & 4.1 \\ 0.0 & 0.0 & 0.0 \\ 0.0 & 0.0 & 0.0\end{array}$




\begin{tabular}{|c|c|c|c|c|c|c|c|c|}
\hline $\begin{array}{l}\text { Stream name } \\
\text { From block: } \\
\text { To block } \\
\text { Mole Flow KMOL/HR }\end{array}$ & $\begin{array}{l}\text { TOHT } \\
\text { HTCOOL } \\
\text { HTSHIFT }\end{array}$ & $\begin{array}{l}\text { TOLT } \\
\text { LTCOOL } \\
\text { LTSHIFT }\end{array}$ & $\begin{array}{r}\text { TOPSAA } \\
\text { PSACOOL } \\
\text { RECMIX }\end{array}$ & $\begin{array}{r}\text { TOPSAB } \\
\text { RECMIX } \\
\text { PSA }\end{array}$ & $\begin{array}{r}\text { TOREFHOT } \\
\text { REFHTR } \\
\text { PRIMARY }\end{array}$ & $\begin{array}{r}\text { WAT1A } \\
\text { STMFLASH }\end{array}$ & $\begin{array}{r}\text { WETDAIR } \\
\text { DRY1 } \\
\text { DRY2 }\end{array}$ & $\begin{array}{l}\text { WOOD } \\
\text { FEEDMIX }\end{array}$ \\
\hline TAR & 0.0 & 0.0 & 0.0 & 0.0 & 4.6 & 0.0 & 0.0 & 0.0 \\
\hline $\mathrm{H} 2$ & 1274.4 & 1546.0 & 1633.2 & 2432.0 & 244.1 & 0.0 & 0.0 & 0.0 \\
\hline 02 & 0.0 & 0.0 & 0.0 & 0.0 & 0.0 & 0.0 & 4933.3 & 0.0 \\
\hline N2 & 2.1 & 2.1 & 2.1 & 2.1 & 0.0 & 0.0 & 20830.4 & 0.0 \\
\hline $\mathrm{CO} 2$ & 541.2 & 812.7 & 900.0 & 900.0 & 154.7 & 0.0 & 606.4 & 0.0 \\
\hline CO & 387.9 & 116.4 & 29.1 & 29.1 & 496.2 & 0.0 & 0.0 & 0.0 \\
\hline $\mathrm{H} 2 \mathrm{O}$ & 1881.9 & 1610.4 & 3.8 & 3.8 & 1202.3 & 1001.7 & 2274.8 & 0.0 \\
\hline $\mathrm{CH} 4$ & 74.5 & 74.5 & 74.5 & 74.5 & 181.9 & 0.0 & 0.0 & 0.0 \\
\hline H2S & 1.0 & 1.0 & 1.0 & 1.0 & 1.0 & 0.0 & 0.0 & 0.0 \\
\hline $\mathrm{NH3}$ & 0.2 & 0.2 & 0.2 & 0.2 & 4.3 & 0.0 & 0.0 & 0.0 \\
\hline $\cos$ & 0.0 & 0.0 & 0.0 & 0.0 & 0.0 & 0.0 & 0.0 & 0.0 \\
\hline $\mathrm{SO} 2$ & 0.0 & 0.0 & 0.0 & 0.0 & 0.0 & 0.0 & 0.1 & 0.0 \\
\hline $\mathrm{SO} 3$ & 0.0 & 0.0 & 0.0 & 0.0 & 0.0 & 0.0 & 0.0 & 0.0 \\
\hline NO2 & 0.0 & 0.0 & 0.0 & 0.0 & 0.0 & 0.0 & 0.0 & 0.0 \\
\hline NO & 0.0 & 0.0 & 0.0 & 0.0 & 0.0 & 0.0 & 0.0 & 0.0 \\
\hline PHENOL & 0.0 & 0.0 & 0.0 & 0.0 & 0.0 & 0.0 & 0.0 & 0.0 \\
\hline $\mathrm{C} 6 \mathrm{H} 6$ & 0.0 & 0.0 & 0.0 & 0.0 & 0.0 & 0.0 & 0.0 & 0.0 \\
\hline $\mathrm{C} 2 \mathrm{H} 6$ & 0.0 & 0.0 & 0.0 & 0.0 & 5.3 & 0.0 & 0.0 & 0.0 \\
\hline $\mathrm{C} 2 \mathrm{H}_{4}$ & 0.0 & 0.0 & 0.0 & 0.0 & 53.1 & 0.0 & 0.0 & 0.0 \\
\hline $\mathrm{C} 2 \mathrm{H} 2$ & 0.0 & 0.0 & 0.0 & 0.0 & 4.1 & 0.0 & 0.0 & 0.0 \\
\hline O2SI & 0.0 & 0.0 & 0.0 & 0.0 & 0.0 & 0.0 & 0.0 & 0.0 \\
\hline CARBON & 0.0 & 0.0 & 0.0 & 0.0 & 0.0 & 0.0 & 0.0 & 0.0 \\
\hline
\end{tabular}




$\begin{array}{lrr}\begin{array}{l}\text { Stream name } \\ \text { From block: } \\ \text { To block }\end{array} & \begin{array}{r}\text { WOODGAS } \\ \text { GASIFIER } \\ \text { Mole Flow KMOL/HR }\end{array} & \begin{array}{r}\text { WOODWAT } \\ \text { WOODSEP } \\ \text { DRY1 }\end{array} \\ \text { TAR } & & \\ \text { H2 } & 4.6 & 0.0 \\ \text { O2 } & 244.1 & 0.0 \\ \text { N2 } & 0.0 & 0.0 \\ \text { CO2 } & 0.0 & 0.0 \\ \text { CO } & 154.7 & 0.0 \\ \text { H2O } & 496.2 & 0.0 \\ \text { CH4 } & 1202.3 & 1838.9 \\ \text { H2S } & 181.9 & 0.0 \\ \text { NH3 } & 1.0 & 0.0 \\ \text { COS } & 4.3 & 0.0 \\ \text { SO2 } & 0.0 & 0.0 \\ \text { SO3 } & 0.0 & 0.0 \\ \text { NO2 } & 0.0 & 0.0 \\ \text { NO } & 0.0 & 0.0 \\ \text { PHENOL } & 0.0 & 0.0 \\ \text { C6H6 } & 0.0 & 0.0 \\ \text { C2H6 } & 0.0 & 0.0 \\ \text { C2H4 } & 5.3 & 0.0 \\ \text { C2H2 } & 53.1 & 0.0 \\ \text { O2SI } & 4.1 & 0.0 \\ \text { CARBON } & 10727.4 & 0.0 \\ & 0.0 & 0.0\end{array}$




\begin{tabular}{|c|c|c|c|c|c|c|c|c|}
\hline $\begin{array}{l}\text { Stream name } \\
\text { From block: } \\
\text { To block }\end{array}$ & $\begin{array}{r}145 \\
\text { PUMP1 } \\
\text { B6 }\end{array}$ & $\begin{array}{r}160 \\
\text { PUMP4 } \\
\text { INTER2A }\end{array}$ & $\begin{array}{r}165 \\
\text { PUMP5 } \\
\text { INTER2B }\end{array}$ & $\begin{array}{r}188 \\
B 13 \\
\text { STMGEN6 }\end{array}$ & $\begin{array}{r}189 \\
\text { PSACOOL }\end{array}$ & $\begin{array}{r}196 \\
\text { B3 } \\
\text { LTCOOL }\end{array}$ & $\begin{array}{r}205 \\
\text { SYNCOMPR } \\
\text { B2 }\end{array}$ & $\begin{array}{r}207 \\
B 2 \\
\text { REFHTR }\end{array}$ \\
\hline Temperature C & 77.5 & 15.4 & 15.4 & 15.4 & 23.9 & 17.3 & 87.8 & 108.7 \\
\hline Pressure N/SQM & $1.24 E+06$ & $7.93 E+05$ & $7.93 E+05$ & $7.93 E+05$ & $2.51 E+06$ & $3.45 E+06$ & $1.38 E+05$ & $3.65 E+06$ \\
\hline Vapor Frac & 0.0 & 0.0 & 0.0 & 0.0 & 0.0 & 0.0 & 0.0 & 0.5 \\
\hline Mole Flow KMOL/HR & 1886.0 & 133.2 & 113.7 & 891.1 & 1519.3 & 669.1 & 3.4 & 2351.6 \\
\hline Mass Flow KG/HR & 33976.3 & 2399.6 & 2049.2 & 16053.8 & 27371.2 & 12054.5 & 431.5 & 48225.9 \\
\hline Volume Flow CUM/HR & 46.9 & 3.2 & 2.7 & 21.1 & 27.4 & 15.9 & 1.5 & 1068.4 \\
\hline $\begin{array}{l}\text { Enthalpy MMBTU/HR } \\
\text { Mass Flow KG/HR }\end{array}$ & -508.2 & -36.6 & -31.2 & -244.7 & -411.7 & -183.6 & 0.3 & -435.1 \\
\hline TAR & 0.0 & 0.0 & 0.0 & 0.0 & 0.0 & 0.0 & 429.2 & 586.3 \\
\hline $\mathrm{H} 2$ & 0.0 & 0.0 & 0.0 & 0.0 & 0.0 & 0.0 & 0.0 & 492.0 \\
\hline $\mathrm{O} 2$ & 0.0 & 0.0 & 0.0 & 0.0 & 0.0 & 0.0 & 0.0 & 0.0 \\
\hline N2 & 0.0 & 0.0 & 0.0 & 0.0 & 0.0 & 0.0 & 0.0 & 0.0 \\
\hline $\mathrm{CO} 2$ & 0.0 & 0.0 & 0.0 & 0.0 & 0.0 & 0.0 & 1.5 & 6808.4 \\
\hline CO & 0.0 & 0.0 & 0.0 & 0.0 & 0.0 & 0.0 & 0.2 & 13898.3 \\
\hline $\mathrm{H} 2 \mathrm{O}$ & 33976.3 & 2399.6 & 2049.2 & 16053.8 & 27371.2 & 12054.5 & 0.0 & 21659.9 \\
\hline $\mathrm{CH} 4$ & 0.0 & 0.0 & 0.0 & 0.0 & 0.0 & 0.0 & 0.1 & 2918.9 \\
\hline H2S & 0.0 & 0.0 & 0.0 & 0.0 & 0.0 & 0.0 & 0.0 & 33.2 \\
\hline $\mathrm{NH3}$ & 0.0 & 0.0 & 0.0 & 0.0 & 0.0 & 0.0 & 0.1 & 73.0 \\
\hline $\cos$ & 0.0 & 0.0 & 0.0 & 0.0 & 0.0 & 0.0 & 0.0 & 0.0 \\
\hline SO2 & 0.0 & 0.0 & 0.0 & 0.0 & 0.0 & 0.0 & 0.0 & 0.0 \\
\hline $\mathrm{SO} 3$ & 0.0 & 0.0 & 0.0 & 0.0 & 0.0 & 0.0 & 0.0 & 0.0 \\
\hline NO2 & 0.0 & 0.0 & 0.0 & 0.0 & 0.0 & 0.0 & 0.0 & 0.0 \\
\hline NO & 0.0 & 0.0 & 0.0 & 0.0 & 0.0 & 0.0 & 0.0 & 0.0 \\
\hline PHENOL & 0.0 & 0.0 & 0.0 & 0.0 & 0.0 & 0.0 & 0.0 & 0.0 \\
\hline $\mathrm{C} 6 \mathrm{H} 6$ & 0.0 & 0.0 & 0.0 & 0.0 & 0.0 & 0.0 & 0.0 & 0.0 \\
\hline $\mathrm{C} 2 \mathrm{H} 6$ & 0.0 & 0.0 & 0.0 & 0.0 & 0.0 & 0.0 & 0.0 & 159.1 \\
\hline $\mathrm{C} 2 \mathrm{H}_{4}$ & 0.0 & 0.0 & 0.0 & 0.0 & 0.0 & 0.0 & 0.3 & 1488.9 \\
\hline $\mathrm{C}_{2} \mathrm{H}_{2}$ & 0.0 & 0.0 & 0.0 & 0.0 & 0.0 & 0.0 & 0.0 & 107.9 \\
\hline O2SI & 0.0 & 0.0 & 0.0 & 0.0 & 0.0 & 0.0 & 0.0 & 0.0 \\
\hline CARBON & 0.0 & 0.0 & 0.0 & 0.0 & 0.0 & 0.0 & 0.0 & 0.0 \\
\hline WOOD & 0.0 & 0.0 & 0.0 & 0.0 & 0.0 & 0.0 & 0.0 & 0.0 \\
\hline ASH & 0.0 & 0.0 & 0.0 & 0.0 & 0.0 & 0.0 & 0.0 & 0.0 \\
\hline CHAR & 0.0 & 0.0 & 0.0 & 0.0 & 0.0 & 0.0 & 0.0 & 0.0 \\
\hline
\end{tabular}




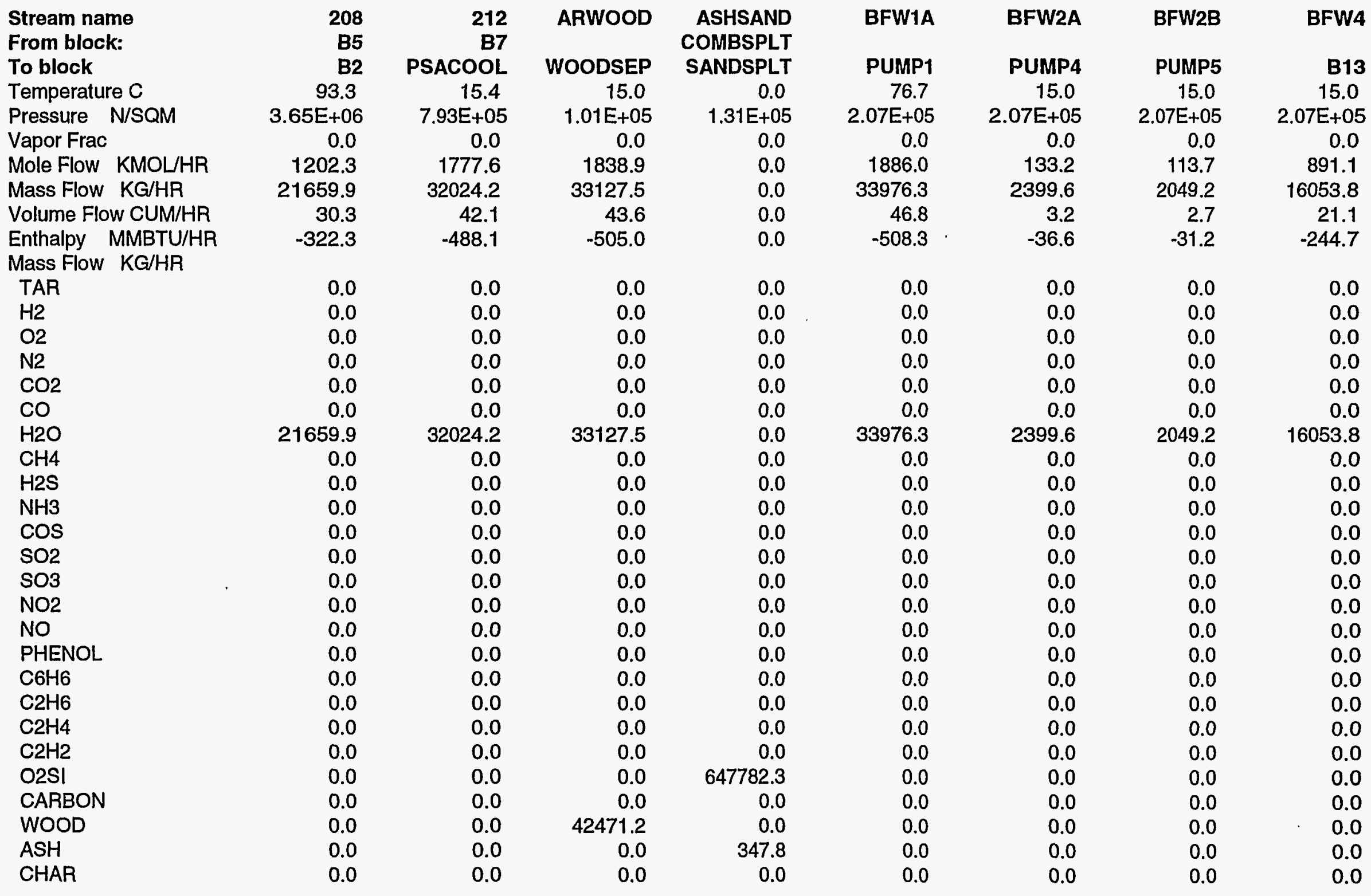

Appendix C: Cost sheets 


\begin{tabular}{|c|c|c|c|c|c|c|c|c|}
\hline $\begin{array}{l}\text { Stream name } \\
\text { From block: } \\
\text { To block }\end{array}$ & BFW5 & BFW6 & $\begin{array}{r}\text { CHAR } \\
\text { CHARSEP } \\
\text { CHARDEC }\end{array}$ & $\begin{array}{r}\text { CHARCOMP } \\
\text { CHARDEC } \\
\text { CHARFURN }\end{array}$ & $\begin{array}{r}\text { CHARFLUE } \\
\text { COMBSPLT } \\
\text { DRYRMIX }\end{array}$ & MODEL2 & $\begin{array}{r}\text { CO } \\
\text { MODEL2 }\end{array}$ & COLDIN \\
\hline Temperature $\mathrm{C}$ & 15.0 & 15.0 & 0.0 & 825.3 & 982.2 & 15.0 & 537.8 & 108.9 \\
\hline Pressure N/SQM & 2.07E+05 & $1.01 E+05$ & $1.38 E+05$ & $1.38 \mathrm{E}+05$ & $1.31 E+05$ & 2.07E+05 & 2.07E+05 & $3.65 E+06$ \\
\hline Vapor Frac & 0.0 & 0.0 & 0.0 & 1.0 & 1.0 & 0.0 & 1.0 & 0.5 \\
\hline Mole Flow KMOL/HR & 1777.6 & 669.1 & 0.0 & 257.9 & 4113.8 & 1343.8 & 1343.8 & 2362.4 \\
\hline Mass Flow KG/HR & 32024.2 & 12054.5 & 0.0 & 3286.3 & 123679.8 & 24208.1 & 24208.1 & 48288.8 \\
\hline Volume Flow CUM/HR & 42.1 & 15.8 & 0.0 & 17083.3 & 327877.8 & 31.8 & 43744.4 & 1079.1 \\
\hline Enthalpy MMBTU/HR & -488.1 & -183.8 & 0.0 & 6.0 & -141.9 & -369.0 & -284.6 & -434.8 \\
\hline $\begin{array}{l}\text { Mass Flow KG/HR } \\
\text { TAR }\end{array}$ & 0.0 & 0.0 & 0.0 & 0.0 & 0.0 & 0.0 & 0.0 & 594.6 \\
\hline $\mathrm{H} 2$ & 0.0 & 0.0 & 0.0 & 333.8 & 0.0 & 0.0 & 0.0 & 509.6 \\
\hline $\mathrm{O} 2$ & 0.0 & 0.0 & 0.0 & 2948.3 & 7303.6 & 0.0 & 0.0 & 0.0 \\
\hline N2 & 0.0 & 0.0 & 0.0 & 4.2 & 86306.9 & 0.0 & 0.0 & 0.0 \\
\hline $\mathrm{CO} 2$ & 0.0 & 0.0 & 0.0 & 0.0 & 26360.2 & 0.0 & 0.0 & 6795.3 \\
\hline CO & 0.0 & 0.0 & 0.0 & 0.0 & 0.0 & 0.0 & 0.0 & 13887.8 \\
\hline $\mathrm{H} 2 \mathrm{O}$ & 32024.2 & 12054.5 & 0.0 & 0.0 & 3703.5 & 24208.1 & 24208.1 & 21659.9 \\
\hline $\mathrm{CH} 4$ & 0.0 & 0.0 & 0.0 & 0.0 & 0.0 & 0.0 & 0.0 & 2930.5 \\
\hline $\mathrm{H} 2 \mathrm{~S}$ & 0.0 & 0.0 & 0.0 & 0.0 & 0.0 & 0.0 & 0.0 & 42.5 \\
\hline $\mathrm{NH3}$ & 0.0 & 0.0 & 0.0 & 0.0 & 0.0 & 0.0 & 0.0 & 84.9 \\
\hline $\cos$ & 0.0 & 0.0 & 0.0 & 0.0 & 0.0 & 0.0 & 0.0 & 0.0 \\
\hline SO2 & 0.0 & 0.0 & 0.0 & 0.0 & 5.6 & 0.0 & 0.0 & 0.0 \\
\hline $\mathrm{SO} 3$ & 0.0 & 0.0 & 0.0 & 0.0 & 0.0 & 0.0 & 0.0 & 0.0 \\
\hline NO2 & 0.0 & 0.0 & 0.0 & 0.0 & 0.0 & 0.0 & 0.0 & 0.0 \\
\hline NO & 0.0 & 0.0 & 0.0 & 0.0 & 0.0 & 0.0 & 0.0 & 0.0 \\
\hline PHENOL & 0.0 & 0.0 & 0.0 & 0.0 & 0.0 & 0.0 & 0.0 & 0.0 \\
\hline $\mathrm{C} 6 \mathrm{H} 6$ & 0.0 & 0.0 & 0.0 & 0.0 & 0.0 & 0.0 & 0.0 & 0.0 \\
\hline $\mathrm{C} 2 \mathrm{H} 6$ & 0.0 & 0.0 & 0.0 & 0.0 & 0.0 & 0.0 & 0.0 & 169.9 \\
\hline $\mathrm{C} 2 \mathrm{H}_{4}$ & 0.0 & 0.0 & 0.0 & 0.0 & 0.0 & 0.0 & 0.0 & 1486.5 \\
\hline $\mathrm{C} 2 \mathrm{H} 2$ & 0.0 & 0.0 & 0.0 & 0.0 & 0.0 & 0.0 & 0.0 & 127.4 \\
\hline O2SI & 0.0 & 0.0 & 644565.4 & 644565.4 & 0.0 & 0.0 & 0.0 & 0.0 \\
\hline CARBON & 0.0 & 0.0 & 0.4 & 7178.5 & 0.0 & 0.0 & 0.0 & 0.0 \\
\hline WOOD & 0.0 & 0.0 & 0.0 & 0.0 & 0.0 & 0.0 & 0.0 & 0.0 \\
\hline ASH & 0.0 & 0.0 & 0.0 & 347.8 & 0.0 & 0.0 & 0.0 & 0.0 \\
\hline CHAR & 0.0 & 0.0 & 10815.0 & 0.0 & 0.0 & 0.0 & 0.0 & 0.0 \\
\hline
\end{tabular}

Appendix C: Cost sheets 


Stream name
From block:
To block
Temperature C
Pressure N/SQM
Vapor Frac
Mole Flow KMOL/HR
Mass Flow KG/HR
Volume Flow CUM/HR
Enthalpy MMBTU/HR
Mass Flow KG/HR
TAR
H2
O2
N2
CO2
CO
H2O
CH4
H2S
NH3
COS
SO2
SO3
NO2
NO
PHENOL
C6H6
C2H6
C2H4
C2H2
O2S1
CARBON
WOOD
ASH
CHAR

\section{COLDOUT} MODEL1

120.5

$3.65 E+06$

0.5

2362.4

48288.8

1132.1

$-432.2$

594.6

509.6

0.0

0.0

6795.3

13887.8

21659.9

2930.5

42.5

84.9

0.0

0.0

0.0

0.0

0.0

0.0

0.0

169.9

1486.5

127.4

0.0

0.0

0.0

0.0

0.0
COMBAIR

\section{AIRCOMP1}

15.0

$1.01 E+05$

1.0

3938.7
1132117

93112.1

$-10.8$

0.0

0.0
26131.7

86302.6

57.2

0.0

720.2

0.0

0.0

0.0

0.0

0.0

0.0

0.0

0.0

0.0

0.0

0.0

0.0

0.0

0.0

0.0

0.0

0.0

0.0
COMBAIR2

AIRCOMP1 COMBPROD

CHARFURN

AIRHEAT COMBSPLT

$\begin{array}{lr}5.38 E+05 & 1.31 E+05\end{array}$

1.0

3938.7

113211.7

77299.2

$-6.7$

0.0

0.0
26131.7

86302.6

57.2

0.0

720.2

0.0

0.0

0.0

0.0

0.0

0.0

0.0

0.0

0.0

0.0

0.0

0.0

0.0

0.0

0.0

0.0

0.0

0.0
COOLED1A

B4

87.8

$3.13 E+05$

0.6

2351.5

48225.1

13527.3

$-428.8$

586.3

492.0

0.0

0.0

6808.3

13898.0

21659.5

2918.9

33.2

73.0

0.0

0.0

0.0

0.0

0.0

0.0

0.0

159.1

1488.9

107.9

647782.3

0.0

347.8

0.0
COOLED2A INTER2A

65.6 $5.03 E+05$ 1603.9 46102.9

8984.5

$-2.2$

0.0

0.0

10641.5

35144.8

23.3

0.0

293.3

0.0

0.0

0.0

0.0

0.0

0.0

0.0

0.0

0.0

0.0

0.0

0.0

0.0

0.0

0.0

0.0

0.0

0.0
COOLED2B

INTER2B

65.6

$1.12 E+06$

1.0

1603.9

46102.9

4037.2

$-2.2$

$\begin{array}{ll}0.0 & 0.0\end{array}$

$\begin{array}{rr}0.0 & 0.0 \\ 10641.5 & 0.0\end{array}$

$35144.8 \quad 0.0$

$23.3 \quad 0.0$

$0.0 \quad 0.0$

$293.3 \quad 0.0$

$\begin{array}{ll}0.0 & 0.0 \\ 0.0 & 0.0\end{array}$

$\begin{array}{ll}0.0 & 0.0 \\ 0.0 & 0.0\end{array}$

0.0

0.0

0.0

0.0

0.0

0.0

0.0

0.0

0.0

0.0

0.0

0.0

0.0

0.0
0.0

0.0

0.0

0.0

0.0

0.0

0.0

0.0

0.0

0.0

0.0

0.0

0.0

0.0

0.0

42471.2

0.0

0.0

Appendix $C$ : Cost sheets 


\begin{tabular}{|c|c|c|c|c|c|c|c|c|}
\hline $\begin{array}{l}\text { Stream name } \\
\text { From block: }\end{array}$ & DRYRAIR & $\begin{array}{l}\text { DRYRAIR2 } \\
\text { AlRCOMP2 } \\
\text { RPVRMIY }\end{array}$ & $\begin{array}{r}\text { DRYWOOD } \\
\text { DRY2 }\end{array}$ & $\begin{array}{c}\text { FLUENAIR } \\
\text { DRYRMIX }\end{array}$ & $\begin{array}{l}\text { FROMHT } \\
\text { HTSHIFT }\end{array}$ & $\begin{array}{l}\text { FROMLT } \\
\text { LTSHIFT }\end{array}$ & $\begin{array}{l}\text { FROMPRIM } \\
\text { GSTMGEN }\end{array}$ & GAS1A \\
\hline $\begin{array}{l}\text { To block } \\
\text { Temperature C }\end{array}$ & $\begin{array}{c}\text { AIRCOMP2 } \\
15.0\end{array}$ & $\begin{array}{r}\text { DRYRMIX } \\
15.0\end{array}$ & $\begin{array}{r}\text { DRYRSEP } \\
68.4\end{array}$ & $\begin{array}{l}\text { DRY1 } \\
186.9\end{array}$ & $\begin{array}{c}\text { LTCOOL } \\
434.8\end{array}$ & $\begin{array}{c}\text { PSACOOL } \\
221.0\end{array}$ & $\begin{array}{c}\text { HTCOOL } \\
466.0\end{array}$ & $\begin{array}{r}\text { B4 } \\
203.3\end{array}$ \\
\hline Pressure N/SQM & $1.01 E+05$ & $1.31 E+05$ & $1.01 E+05$ & $1.31 E+05$ & $2.95 E+06$ & $2.51 E+06$ & $3.47 E+06$ & $3.13 E+05$ \\
\hline Vapor Frac & 1.0 & 1.0 & 1.0 & 1.0 & 1.0 & 1.0 & 1.0 & 1.0 \\
\hline Mole Flow KMOL/HR & 22692.3 & 22692.3 & 28645.0 & 26806.1 & 4163.1 & 4163.1 & 4163.1 & 2351.5 \\
\hline Mass Flow KG/HR & 652259.6 & 652259.6 & 809067.0 & 775939.4 & 72445.0 & 72445.0 & 72445.0 & 48225.1 \\
\hline Volume Flow CUM/HR & 536457.4 & 414915.9 & 802583.3 & 783174.6 & 8310.2 & 6722.5 & 7371.3 & 29646.5 \\
\hline $\begin{array}{l}\text { Enthalpy MMBTU/HR } \\
\text { Mass Flow } \mathrm{KG} / \mathrm{HR}\end{array}$ & -62.0 & -62.1 & -712.8 & -204.0 & -633.9 & -668.1 & -619.8 & -381.0 \\
\hline TAR & 0.0 & 0.0 & 0.0 & 0.0 & 0.0 & 0.0 & 0.0 & 586.3 \\
\hline $\mathrm{H} 2$ & 0.0 & 0.0 & 0.0 & 0.0 & 3116.5 & 3292.4 & 2569.1 & 492.0 \\
\hline $\mathrm{O} 2$ & 150555.4 & 150555.4 & 157859.0 & 157859.0 & 0.0 & 0.0 & 0.0 & 0.0 \\
\hline N2 & 497225.3 & 497225.3 & 583532.1 & 583532.1 & 57.7 & 57.7 & 57.7 & 0.0 \\
\hline $\mathrm{CO} 2$ & 329.6 & 329.6 & 26689.7 & 26689.7 & 35768.6 & 39609.6 & 23818.8 & 6808.3 \\
\hline $\mathrm{co}$ & 0.0 & 0.0 & 0.0 & 0.0 & 3259.5 & 814.9 & 10865.1 & 13898.0 \\
\hline $\mathrm{H} 2 \mathrm{O}$ & 4149.4 & 4149.4 & 40980.5 & 7853.0 & 29011.7 & 27439.4 & 33903.3 & 21659.5 \\
\hline $\mathrm{CH}_{4}$ & 0.0 & 0.0 & 0.0 & 0.0 & 1194.6 & 1194.6 & 1194.6 & 2918.9 \\
\hline H2S & 0.0 & 0.0 & 0.0 & 0.0 & 32.7 & 32.7 & 32.7 & 33.2 \\
\hline $\mathrm{NH3}$ & 0.0 & 0.0 & 0.0 & 0.0 & 2.8 & 2.8 & 2.8 & 73.0 \\
\hline $\cos$ & 0.0 & 0.0 & 0.0 & 0.0 & 0.8 & 0.8 & 0.8 & 0.0 \\
\hline $\mathrm{SO} 2$ & 0.0 & 0.0 & 5.6 & 5.6 & 0.0 & 0.0 & 0.0 & 0.0 \\
\hline $\mathrm{SO} 3$ & 0.0 & 0.0 & 0.0 & 0.0 & 0.0 & 0.0 & 0.0 & 0.0 \\
\hline NO2 & 0.0 & 0.0 & 0.0 & 0.0 & 0.0 & 0.0 & 0.0 & 0.0 \\
\hline No & 0.0 & 0.0 & 0.0 & 0.0 & 0.0 & 0.0 & 0.0 & 0.0 \\
\hline PHENOL & 0.0 & 0.0 & 0.0 & 0.0 & 0.0 & 0.0 & 0.0 & 0.0 \\
\hline $\mathrm{C} 6 \mathrm{H} 6$ & 0.0 & 0.0 & 0.0 & 0.0 & 0.0 & 0.0 & 0.0 & 0.0 \\
\hline $\mathrm{C} 2 \mathrm{H} 6$ & 0.0 & 0.0 & 0.0 & 0.0 & 0.1 & 0.1 & 0.1 & 159.1 \\
\hline $\mathrm{C} 2 \mathrm{H} 4$ & 0.0 & 0.0 & 0.0 & 0.0 & 0.0 & 0.0 & 0.0 & 1488.9 \\
\hline $\mathrm{C} 2 \mathrm{H} 2$ & 0.0 & 0.0 & 0.0 & 0.0 & 0.0 & 0.0 & 0.0 & 107.9 \\
\hline O2SI & 0.0 & 0.0 & 0.0 & 0.0 & 0.0 & 0.0 & 0.0 & 0.0 \\
\hline CARBON & 0.0 & 0.0 & 0.0 & 0.0 & 0.0 & 0.0 & 0.0 & 0.0 \\
\hline WOOD & 0.0 & 0.0 & 42471.2 & 0.0 & 0.0 & 0.0 & 0.0 & 0.0 \\
\hline $\mathrm{ASH}$ & 0.0 & 0.0 & 0.0 & 0.0 & 0.0 & 0.0 & 0.0 & 0.0 \\
\hline CHAR & 0.0 & 0.0 & 0.0 & 0.0 & 0.0 & 0.0 & 0.0 & 0.0 \\
\hline
\end{tabular}




\begin{tabular}{|c|c|c|c|c|c|c|c|c|}
\hline $\begin{array}{l}\text { Stream name } \\
\text { From block: } \\
\text { To block }\end{array}$ & INTER2A & GAS2B & $\begin{array}{l}\text { GASIFSTM } \\
\text { GSTMGEN } \\
\text { FEEDMIX }\end{array}$ & $\begin{array}{l}\text { GASWAT } \\
\text { DRYRSEP }\end{array}$ & $\begin{array}{r}\text { GFEED } \\
\text { FEEDMIX } \\
\text { GASIFIER }\end{array}$ & $\begin{array}{l}\text { GSTMIN } \\
\text { GSTMGEN }\end{array}$ & $\begin{array}{r}\text { H2PROD } \\
\text { RECSPLT }\end{array}$ & $\begin{array}{r}\text { H2PURIFY } \\
\text { PSA } \\
\text { RECSPLT }\end{array}$ \\
\hline Temperature C & 212.7 & 190.0 & 537.8 & 68.4 & 854.7 & 15.0 & 23.4 & 23.4 \\
\hline Pressure N/SQM & $5.03 E+05$ & $1.12 E+06$ & 2.07E+05 & $1.01 E+05$ & $1.72 E+05$ & 2.07E+05 & $2.51 E+06$ & $2.51 E+06$ \\
\hline Vapor Frac & 1.0 & 1.0 & 1.0 & 1.0 & 1.0 & 0.0 & 1.0 & 1.0 \\
\hline Mole Flow KMOL/HR & 1603.9 & 1603.9 & 943.0 & 28645.0 & 943.0 & 943.0 & 1268.4 & 2067.2 \\
\hline Mass Flow KG/HR & 46102.9 & 46102.9 & 16988.1 & 809067.0 & 16988.1 & 16988.1 & 2557.0 & 4167.2 \\
\hline Volume Flow CUM/HR & 12905.4 & 5535.6 & 30697.9 & 802583.3 & 51296.0 & 22.3 & 1266.4 & 2063.9 \\
\hline $\begin{array}{l}\text { Enthalpy } \mathrm{MMBTU} / \mathrm{HR} \\
\text { Mass Flow } \mathrm{KG/HR}\end{array}$ & 4.5 & 3.4 & -199.7 & -712.8 & -188.1 & -259.0 & 0.0 & -0.1 \\
\hline TAR & 0.0 & 0.0 & 0.0 & 0.0 & 0.0 & 0.0 & 0.0 & 0.0 \\
\hline $\mathrm{H} 2$ & 0.0 & 0.0 & 0.0 & 0.0 & 0.0 & 0.0 & 2557.0 & 4167.2 \\
\hline $\mathrm{O} 2$ & 10641.5 & 10641.5 & 0.0 & 157859.0 & 0.0 & 0.0 & 0.0 & 0.0 \\
\hline N2 & 35144.8 & 35144.8 & 0.0 & 583532.1 & 0.0 & 0.0 & 0.0 & 0.0 \\
\hline $\mathrm{CO} 2$ & 23.3 & 23.3 & 0.0 & 26689.7 & 0.0 & 0.0 & 0.0 & 0.0 \\
\hline $\mathrm{CO}$ & 0.0 & 0.0 & 0.0 & 0.0 & 0.0 & 0.0 & 0.0 & 0.0 \\
\hline $\mathrm{H} 2 \mathrm{O}$ & 293.3 & 293.3 & 16988.1 & 40980.5 & 16988.1 & 16988.1 & 0.0 & 0.0 \\
\hline $\mathrm{CH} 4$ & 0.0 & 0.0 & 0.0 & 0.0 & 0.0 & 0.0 & 0.0 & 0.0 \\
\hline H2S & 0.0 & 0.0 & 0.0 & 0.0 & 0.0 & 0.0 & 0.0 & 0.0 \\
\hline $\mathrm{NH} 3$ & 0.0 & 0.0 & 0.0 & 0.0 & 0.0 & 0.0 & 0.0 & 0.0 \\
\hline $\cos$ & 0.0 & 0.0 & 0.0 & 0.0 & 0.0 & 0.0 & 0.0 & 0.0 \\
\hline SO2 & 0.0 & 0.0 & 0.0 & 5.6 & 0.0 & 0.0 & 0.0 & 0.0 \\
\hline $\mathrm{SO} 3$ & 0.0 & 0.0 & 0.0 & 0.0 & 0.0 & 0.0 & 0.0 & 0.0 \\
\hline NO2 & 0.0 & 0.0 & 0.0 & 0.0 & 0.0 & 0.0 & 0.0 & 0.0 \\
\hline NO & 0.0 & 0.0 & 0.0 & 0.0 & 0.0 & 0.0 & 0.0 & 0.0 \\
\hline PHENOL & 0.0 & 0.0 & 0.0 & 0.0 & 0.0 & 0.0 & 0.0 & 0.0 \\
\hline $\mathrm{C} 6 \mathrm{H} 6$ & 0.0 & 0.0 & 0.0 & 0.0 & 0.0 & 0.0 & 0.0 & 0.0 \\
\hline $\mathrm{C} 2 \mathrm{H} 6$ & 0.0 & 0.0 & 0.0 & 0.0 & 0.0 & 0.0 & 0.0 & 0.0 \\
\hline $\mathrm{C} 2 \mathrm{H} 4$ & 0.0 & 0.0 & 0.0 & 0.0 & 0.0 & 0.0 & 0.0 & 0.0 \\
\hline $\mathrm{C} 2 \mathrm{H} 2$ & 0.0 & 0.0 & 0.0 & 0.0 & 0.0 & 0.0 & 0.0 & 0.0 \\
\hline O2SI & 0.0 & 0.0 & 0.0 & 0.0 & 644565.4 & 0.0 & 0.0 & 0.0 \\
\hline CARBON & 0.0 & 0.0 & 0.0 & 0.0 & 0.4 & 0.0 & 0.0 & 0.0 \\
\hline WOOD & 0.0 & 0.0 & 0.0 & 0.0 & 42470.4 & 0.0 & 0.0 & 0.0 \\
\hline ASH & 0.0 & 0.0 & 0.0 & 0.0 & 346.5 & 0.0 & 0.0 & 0.0 \\
\hline CHAR & 0.0 & 0.0 & 0.0 & 0.0 & 0.4 & 0.0 & 0.0 & 0.0 \\
\hline
\end{tabular}




\begin{tabular}{|c|c|c|c|c|c|c|c|c|}
\hline $\begin{array}{l}\text { Stream name } \\
\text { From block: } \\
\text { To block }\end{array}$ & $\begin{array}{r}\text { H2RECYCL } \\
\text { RECSPLT } \\
\text { RECMIX }\end{array}$ & $\begin{array}{r}\text { HCOMBAIR } \\
\text { AIRHEAT } \\
\text { CHARFURN }\end{array}$ & MODEL2 & $\begin{array}{r}\text { HO } \\
\text { MODEL2 }\end{array}$ & MODEL1 & $\begin{array}{l}\text { HOTOUT } \\
\text { MODEL1 }\end{array}$ & $\begin{array}{r}\text { KOWATER } \\
\text { B1 } \\
\text { B5 }\end{array}$ & $\begin{array}{r}\text { MIDWOOD } \\
\text { WOODSEP } \\
\text { DRY2 }\end{array}$ \\
\hline Temperature C & 23.4 & 52.3 & 946.7 & 225.4 & 825.3 & 800.0 & 90.6 & 0.0 \\
\hline Pressure N/SQM & $2.51 E+06$ & $1.38 E+05$ & $2.50 \mathrm{E}+06$ & $2.50 E+06$ & $1.38 E+05$ & $1.38 E+05$ & $1.38 E+05$ & $1.01 E+05$ \\
\hline Vapor Frac & 1.0 & 1.0 & 1.0 & 1.0 & 1.0 & 1.0 & 0.0 & 0.0 \\
\hline Mole Flow KMOL/HR & 798.8 & 3938.7 & 3091.1 & 3091.1 & 2362.4 & 2362.4 & 1202.3 & 0.0 \\
\hline Mass Flow KG/HR & 1610.2 & 113211.7 & 97512.0 & 97512.0 & 48288.8 & 48288.8 & 21659.9 & 0.0 \\
\hline Volume Flow CUM/HR & 797.5 & 77299.2 & 12618.0 & 5113.1 & 156495.9 & 152893.6 & 30.2 & 0.0 \\
\hline Enthalpy MMBTU/HR & 0.0 & -6.7 & -393.5 & -477.9 & -324.2 & -326.7 & -322.7 & 0.0 \\
\hline \multicolumn{9}{|l|}{ Mass Flow KG/HR } \\
\hline TAR & 0.0 & 0.0 & 0.0 & 0.0 & 594.6 & 594.6 & 0.0 & 0.0 \\
\hline $\mathrm{H} 2$ & 1610.2 & 0.0 & 0.0 & 0.0 & 509.6 & 509.6 & 0.0 & 0.0 \\
\hline 02 & 0.0 & 26131.7 & 1613.9 & 1613.9 & 0.0 & 0.0 & 0.0 & 0.0 \\
\hline N2 & 0.0 & 86302.6 & 42045.7 & 42045.7 & 0.0 & 0.0 & 0.0 & 0.0 \\
\hline $\mathrm{CO} 2$ & 0.0 & 57.2 & 44211.6 & 44211.6 & 6795.3 & 6795.3 & 0.0 & 0.0 \\
\hline co & 0.0 & 0.0 & 0.0 & 0.0 & 13887.8 & 13887.8 & 0.0 & 0.0 \\
\hline $\mathrm{H} 2 \mathrm{O}$ & 0.0 & 720.2 & 9640.8 & 9640.8 & 21659.9 & 21659.9 & 21659.9 & 0.0 \\
\hline $\mathrm{CH} 4$ & 0.0 & 0.0 & 0.0 & 0.0 & 2930.5 & 2930.5 & 0.0 & 0.0 \\
\hline $\mathrm{H} 2 \mathrm{~S}$ & 0.0 & 0.0 & 0.0 & 0.0 & 42.5 & 42.5 & 0.0 & 0.0 \\
\hline $\mathrm{NH3}$ & 0.0 & 0.0 & 0.0 & 0.0 & 84.9 & 84.9 & 0.0 & 0.0 \\
\hline $\cos$ & 0.0 & 0.0 & 0.0 & 0.0 & 0.0 & 0.0 & 0.0 & 0.0 \\
\hline SO2 & 0.0 & 0.0 & 0.0 & 0.0 & 0.0 & 0.0 & 0.0 & 0.0 \\
\hline $\mathrm{SO} 3$ & 0.0 & 0.0 & 0.0 & 0.0 & 0.0 & 0.0 & 0.0 & 0.0 \\
\hline NO2 & 0.0 & 0.0 & 0.0 & 0.0 & 0.0 & 0.0 & 0.0 & 0.0 \\
\hline NO & 0.0 & 0.0 & 0.0 & 0.0 & 0.0 & 0.0 & 0.0 & 0.0 \\
\hline PHENOL & 0.0 & 0.0 & 0.0 & 0.0 & 0.0 & 0.0 & 0.0 & 0.0 \\
\hline $\mathrm{C} 6 \mathrm{H} 6$ & 0.0 & 0.0 & 0.0 & 0.0 & 0.0 & 0.0 & 0.0 & 0.0 \\
\hline $\mathrm{C} 2 \mathrm{H} 6$ & 0.0 & 0.0 & 0.0 & 0.0 & 169.9 & 169.9 & 0.0 & 0.0 \\
\hline $\mathrm{C} 2 \mathrm{H} 4$ & 0.0 & 0.0 & 0.0 & 0.0 & 1486.5 & 1486.5 & 0.0 & 0.0 \\
\hline $\mathrm{C} 2 \mathrm{H} 2$ & 0.0 & 0.0 & 0.0 & 0.0 & 127.4 & 127.4 & 0.0 & 0.0 \\
\hline O2SI & 0.0 & 0.0 & 0.0 & 0.0 & 0.0 & 0.0 & 0.0 & 0.0 \\
\hline CARBON & 0.0 & 0.0 & 0.0 & 0.0 & 0.0 & 0.0 & 0.0 & 0.0 \\
\hline WOOD & 0.0 & 0.0 & 0.0 & 0.0 & 0.0 & 0.0 & 0.0 & 42471.2 \\
\hline ASH & 0.0 & 0.0 & 0.0 & 0.0 & 0.0 & 0.0 & 0.0 & 0.0 \\
\hline CHAR & 0.0 & 0.0 & 0.0 & 0.0 & 0.0 & 0.0 & 0.0 & 0.0 \\
\hline
\end{tabular}




\begin{tabular}{|c|c|c|c|c|c|c|c|c|}
\hline $\begin{array}{l}\text { Stream name } \\
\text { From block: } \\
\text { To block }\end{array}$ & $\begin{array}{r}\text { OFFAIR1 } \\
\text { OFFCOMPR }\end{array}$ & $\begin{array}{r}\text { OFFAIR2 } \\
\text { OFFCOMPR } \\
\text { OFFCOMB }\end{array}$ & $\begin{array}{r}\text { OFFFLUE1 } \\
\text { OFFCOMB } \\
\text { COMBCOOL }\end{array}$ & $\begin{array}{r}\text { OFFFLUE2 } \\
\text { COMBCOOL } \\
\text { STMGEN6 }\end{array}$ & $\begin{array}{r}\text { OFFFLUE3 } \\
\text { STMGEN6 }\end{array}$ & $\begin{array}{r}\text { OFFGAS } \\
\text { PSA } \\
\text { OFFCOMB }\end{array}$ & $\begin{array}{l}\text { REFSTM } \\
\text { REFSTM } \\
\text { PRIMARY }\end{array}$ & REFSTMA \\
\hline Temperature C & 15.0 & 189.3 & 950.4 & 238.3 & 27.8 & 23.4 & 537.8 & 15.0 \\
\hline Pressure N/SQM & $1.01 E+05$ & $2.50 E+06$ & $2.50 E+06$ & $2.50 E+06$ & $2.50 E+06$ & $2.51 E+06$ & $2.50 E+06$ & $2.07 E+05$ \\
\hline Vapor Frac & 1.0 & 1.0 & 1.0 & 1.0 & 0.8 & 1.0 & 1.0 & 0.0 \\
\hline Mole Flow KMOL/HR & 1918.4 & 1918.4 & 3096.3 & 3096.3 & 3096.3 & 1375.4 & 1344.4 & 1344.4 \\
\hline Mass Flow KG/HR & 55142.6 & 55142.6 & 97659.3 & 97659.3 & 97659.3 & 42516.8 & 24219.1 & 24219.1 \\
\hline Volume Flow CUM/HR & 45352.6 & 2986.4 & 12677.7 & 5260.0 & 2496.7 & 1271.7 & 3564.5 & 31.8 \\
\hline $\begin{array}{l}\text { Enthalpy MMBTU/HR } \\
\text { Mass Flow } \mathrm{KG} / \mathrm{HR}\end{array}$ & -5.2 & 4.1 & -393.7 & -477.4 & -522.6 & -345.7 & -285.3 & -369.2 \\
\hline TAR & 0.0 & 0.0 & 0.0 & 0.0 & 0.0 & 0.0 & 0.0 & 0.0 \\
\hline $\mathrm{H} 2$ & 0.0 & 0.0 & 0.0 & 0.0 & 0.0 & 735.4 & 0.0 & 0.0 \\
\hline $\mathrm{O} 2$ & 12728.1 & 12728.1 & 1604.8 & 1604.8 & 1604.8 & 0.0 & 0.0 & 0.0 \\
\hline N2 & 42035.8 & 42035.8 & 42093.4 & 42093.4 & 42093.4 & 57.7 & 0.0 & 0.0 \\
\hline $\mathrm{CO} 2$ & 27.9 & 27.9 & 44195.8 & 44195.8 & 44195.8 & 39609.6 & 0.0 & 0.0 \\
\hline $\mathrm{CO}$ & 0.0 & 0.0 & 0.0 & 0.0 & 0.0 & 814.9 & 0.0 & 0.0 \\
\hline $\mathrm{H} 2 \mathrm{O}$ & 350.8 & 350.8 & 9695.9 & 9695.9 & 9695.9 & 68.2 & 24219.1 & 24219.1 \\
\hline $\mathrm{CH} 4$ & 0.0 & 0.0 & 0.0 & 0.0 & 0.0 & 1194.6 & 0.0 & 0.0 \\
\hline $\mathrm{H} 2 \mathrm{~S}$ & 0.0 & 0.0 & 0.0 & 0.0 & 0.0 & 32.7 & 0.0 & 0.0 \\
\hline $\mathrm{NH} 3$ & 0.0 & 0.0 & 0.0 & 0.0 & 0.0 & 2.8 & 0.0 & 0.0 \\
\hline $\cos$ & 0.0 & 0.0 & 0.0 & 0.0 & 0.0 & 0.8 & 0.0 & 0.0 \\
\hline SO2 & 0.0 & 0.0 & 55.0 & 55.0 & 55.0 & 0.0 & 0.0 & 0.0 \\
\hline $\mathrm{SO} 3$ & 0.0 & 0.0 & 9.2 & 9.2 & 9.2 & 0.0 & 0.0 & 0.0 \\
\hline NO2 & 0.0 & 0.0 & 0.2 & 0.2 & 0.2 & 0.0 & 0.0 & 0.0 \\
\hline NO & 0.0 & 0.0 & 5.2 & 5.2 & 5.2 & 0.0 & 0.0 & 0.0 \\
\hline PHENOL & 0.0 & 0.0 & 0.0 & 0.0 & 0.0 & 0.0 & 0.0 & 0.0 \\
\hline $\mathrm{C} 6 \mathrm{H} 6$ & 0.0 & 0.0 & 0.0 & 0.0 & 0.0 & 0.0 & 0.0 & 0.0 \\
\hline $\mathrm{C} 2 \mathrm{H} 6$ & 0.0 & 0.0 & 0.0 & 0.0 & 0.0 & 0.1 & 0.0 & 0.0 \\
\hline $\mathrm{C} 2 \mathrm{H} 4$ & 0.0 & 0.0 & 0.0 & 0.0 & 0.0 & 0.0 & 0.0 & 0.0 \\
\hline $\mathrm{C} 2 \mathrm{H}_{2}$ & 0.0 & 0.0 & 0.0 & 0.0 & 0.0 & 0.0 & 0.0 & 0.0 \\
\hline $\mathrm{O} 2 \mathrm{SI}$ & 0.0 & 0.0 & 0.0 & 0.0 & 0.0 & 0.0 & 0.0 & 0.0 \\
\hline CARBON & 0.0 & 0.0 & 0.0 & 0.0 & 0.0 & 0.0 & 0.0 & 0.0 \\
\hline WOOD & 0.0 & 0.0 & 0.0 & 0.0 & 0.0 & 0.0 & 0.0 & 0.0 \\
\hline ASH & 0.0 & 0.0 & 0.0 & 0.0 & 0.0 & 0.0 & 0.0 & 0.0 \\
\hline CHAR & 0.0 & 0.0 & 0.0 & 0.0 & 0.0 & 0.0 & 0.0 & 0.0 \\
\hline
\end{tabular}




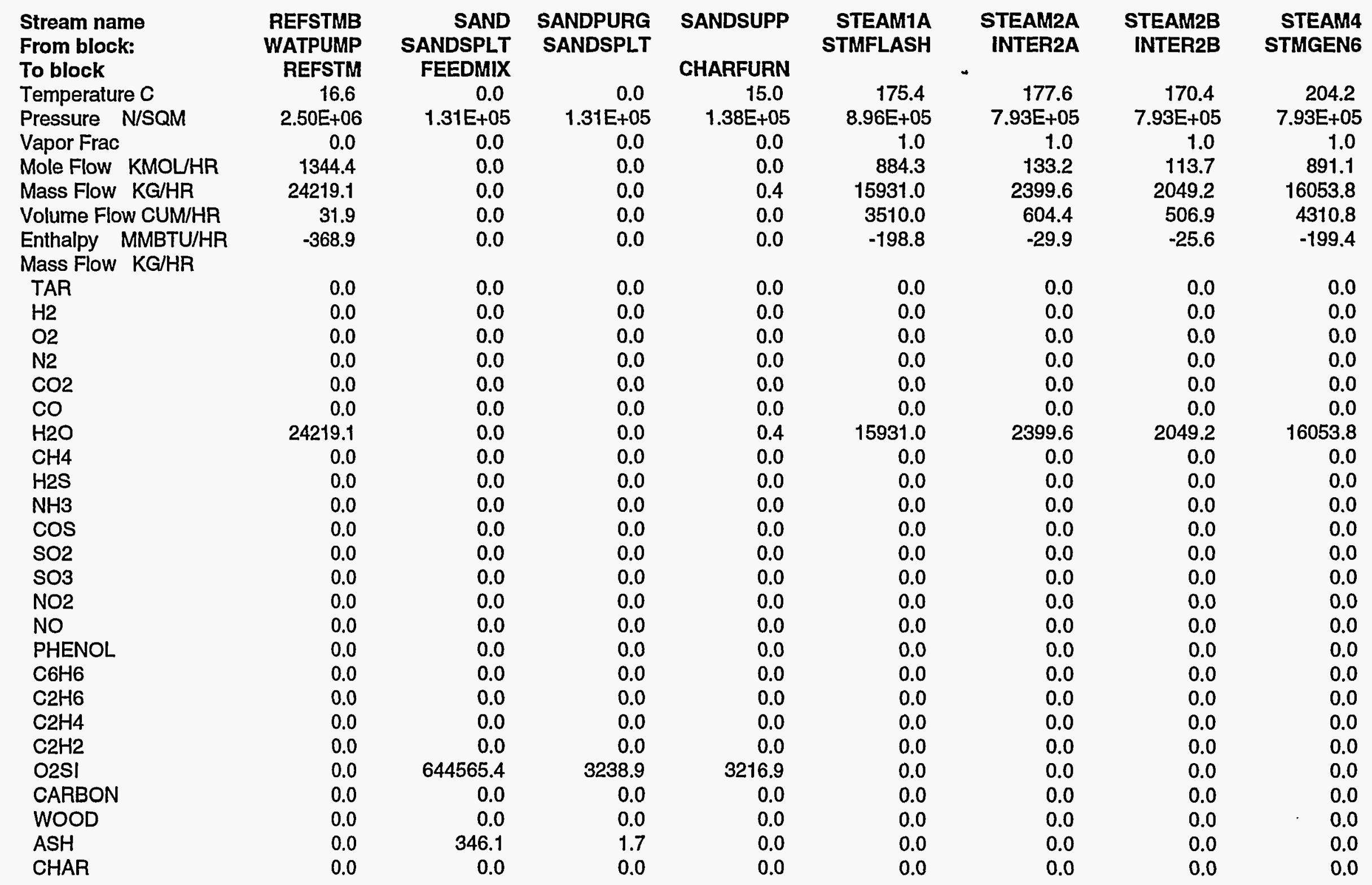




\begin{tabular}{|c|c|c|}
\hline $\begin{array}{l}\text { Stream name } \\
\text { From block: } \\
\text { To block }\end{array}$ & $\begin{array}{r}\text { STEAM5 } \\
\text { PSACOOL }\end{array}$ & $\begin{array}{l}\text { STEAM6 } \\
\text { LTCOOL }\end{array}$ \\
\hline Temperature C & 182.2 & 254.5 \\
\hline Pressure N/SQM & $7.93 E+05$ & $3.45 E+06$ \\
\hline Vapor Frac & 1.0 & 1.0 \\
\hline Mole Flow KMOL/HR & 1777.6 & 669.1 \\
\hline Mass Flow $\mathrm{KG} / \mathrm{HR}$ & 32024.2 & 12054.5 \\
\hline Volume Flow CUM/HR & 8160.0 & 753.5 \\
\hline $\begin{array}{l}\text { Enthalpy MMBTU/HR } \\
\text { Mass Flow KG/HR }\end{array}$ & -399.1 & -149.4 \\
\hline TAR & 0.0 & 0.0 \\
\hline $\mathrm{H} 2$ & 0.0 & 0.0 \\
\hline $\mathrm{O} 2$ & 0.0 & 0.0 \\
\hline N2 & 0.0 & 0.0 \\
\hline $\mathrm{CO} 2$ & 0.0 & 0.0 \\
\hline $\mathrm{CO}$ & 0.0 & 0.0 \\
\hline $\mathrm{H} 2 \mathrm{O}$ & 32024.2 & 12054.5 \\
\hline $\mathrm{CH}_{4}$ & 0.0 & 0.0 \\
\hline $\mathrm{H} 2 \mathrm{~S}$ & 0.0 & 0.0 \\
\hline $\mathrm{NH3}$ & 0.0 & 0.0 \\
\hline $\cos$ & 0.0 & 0.0 \\
\hline SO2 & 0.0 & 0.0 \\
\hline SO3 & 0.0 & 0.0 \\
\hline NO2 & 0.0 & 0.0 \\
\hline NO & 0.0 & 0.0 \\
\hline PHENOL & 0.0 & 0.0 \\
\hline $\mathrm{C} 6 \mathrm{H} 6$ & 0.0 & 0.0 \\
\hline $\mathrm{C} 2 \mathrm{H}_{6}$ & 0.0 & 0.0 \\
\hline $\mathrm{C} 2 \mathrm{H} 4$ & 0.0 & 0.0 \\
\hline $\mathrm{C} 2 \mathrm{H} 2$ & 0.0 & 0.0 \\
\hline $\mathrm{O} 2 \mathrm{SI}$ & 0.0 & 0.0 \\
\hline CARBON & 0.0 & 0.0 \\
\hline WOOD & 0.0 & 0.0 \\
\hline ASH & 0.0 & 0.0 \\
\hline CHAR & 0.0 & 0.0 \\
\hline
\end{tabular}

\begin{tabular}{|c|c|c|c|c|c|}
\hline $\begin{array}{r}\text { STMWAT } \\
\text { B6 } \\
\text { STMFLASH }\end{array}$ & $\begin{array}{r}\text { SYNCOLD } \\
\text { SYNCOOL1 } \\
\text { B1 }\end{array}$ & $\begin{array}{r}\text { SYNCOMPD } \\
\text { SYNCOMPR } \\
B 2\end{array}$ & $\begin{array}{r}\text { SYNGAS } \\
\text { CHARSEP } \\
\text { SYNCOOL1 }\end{array}$ & $\begin{array}{r}\text { SYNREFRM } \\
\text { PRIMARY } \\
\text { GSTMGEN }\end{array}$ & $\begin{array}{r}\text { TOCOMPR } \\
\text { B1 } \\
\text { SYNCOMPR }\end{array}$ \\
\hline 189.3 & 90.6 & 200.7 & 825.3 & 850.0 & 90.6 \\
\hline $1.24 E+06$ & $1.38 E+05$ & $3.65 E+06$ & $1.38 E+05$ & $3.47 E+06$ & $1.38 E+05$ \\
\hline 0.4 & 0.9 & 1.0 & 1.0 & 1.0 & 1.0 \\
\hline 1886.0 & 2351.6 & 1145.8 & 2351.6 & 4163.1 & 1149.3 \\
\hline 33976.3 & 48225.9 & 26134.5 & 48225.9 & 72445.0 & 26566.1 \\
\hline 2483.4 & 47175.6 & 1251.8 & 155777.0 & 11264.9 & 25201.6 \\
\hline-460.4 & -397.6 & -113.0 & -324.7 & -560.6 & -116.6 \\
\hline 0.0 & 586.3 & 157.0 & 586.3 & 0.0 & 586.3 \\
\hline 0.0 & 492.0 & 492.0 & 492.0 & 2569.1 & 492.0 \\
\hline 0.0 & 0.0 & 0.0 & 0.0 & 0.0 & 0.0 \\
\hline 0.0 & 0.0 & 0.0 & 0.0 & 57.7 & 0.0 \\
\hline 0.0 & 6808.4 & 6806.9 & 6808.4 & 23818.8 & 6808.4 \\
\hline 0.0 & 13898.3 & 13898.1 & 13898.3 & 10865.1 & 13898.3 \\
\hline 33976.3 & 21659.9 & 0.0 & 21659.9 & 33903.3 & 0.0 \\
\hline 0.0 & 2918.9 & 2918.8 & 2918.9 & 1194.6 & 2918.9 \\
\hline 0.0 & 33.2 & 33.1 & 33.2 & 32.7 & 33.2 \\
\hline 0.0 & 73.0 & 72.9 & 73.0 & 2.8 & 73.0 \\
\hline 0.0 & 0.0 & 0.0 & 0.0 & 0.8 & 0.0 \\
\hline 0.0 & 0.0 & 0.0 & 0.0 & 0.0 & 0.0 \\
\hline 0.0 & 0.0 & 0.0 & 0.0 & 0.0 & 0.0 \\
\hline 0.0 & 0.0 & 0.0 & 0.0 & 0.0 & 0.0 \\
\hline 0.0 & 0.0 & 0.0 & 0.0 & 0.0 & 0.0 \\
\hline 0.0 & 0.0 & 0.0 & 0.0 & 0.0 & 0.0 \\
\hline 0.0 & 0.0 & 0.0 & 0.0 & 0.0 & 0.0 \\
\hline 0.0 & 159.1 & 159.1 & 159.1 & 0.1 & 159.1 \\
\hline 0.0 & 1488.9 & 1488.7 & 1488.9 & 0.0 & 1488.9 \\
\hline 0.0 & 107.9 & 107.8 & 107.9 & 0.0 & 107.9 \\
\hline 0.0 & 0.0 & 0.0 & 0.0 & 0.0 & 0.0 \\
\hline 0.0 & 0.0 & 0.0 & 0.0 & 0.0 & 0.0 \\
\hline 0.0 & 0.0 & 0.0 & 0.0 & 0.0 & 0.0 \\
\hline 0.0 & 0.0 & 0.0 & 0.0 & 0.0 & 0.0 \\
\hline 0.0 & 0.0 & 0.0 & 0.0 & 0.0 & 0.0 \\
\hline
\end{tabular}




\begin{tabular}{|c|c|c|}
\hline $\begin{array}{l}\text { Stream name } \\
\text { From block: } \\
\text { To block } \\
\text { Temperature C }\end{array}$ & $\begin{array}{r}\text { WOODGAS } \\
\text { GASIFIER } \\
\text { CHARSEP } \\
825.3\end{array}$ & $\begin{array}{r}\text { WOODWAT } \\
\text { WOODSEP } \\
\text { DRY } 1 \\
15.0\end{array}$ \\
\hline Pressure N/SQM & $1.38 E+05$ & $1.01 E+05$ \\
\hline Vapor Frac & 1.0 & 0.0 \\
\hline Mole Flow KMOL/HR & 2351.6 & 1838.9 \\
\hline Mass Flow KG/HR & 48225.9 & 33127.5 \\
\hline Volume Flow CUM/HR & 155777.0 & 43.6 \\
\hline $\begin{array}{l}\text { Enthalpy MMBTU/HR } \\
\text { Mass Flow } \mathrm{KG} / \mathrm{HR}\end{array}$ & -324.7 & -505.0 \\
\hline TAR & 586.3 & 0.0 \\
\hline $\mathrm{H} 2$ & 492.0 & 0.0 \\
\hline $\mathrm{O} 2$ & 0.0 & 0.0 \\
\hline N2 & 0.0 & 0.0 \\
\hline $\mathrm{CO} 2$ & 6808.4 & 0.0 \\
\hline $\mathrm{CO}$ & 13898.3 & 0.0 \\
\hline $\mathrm{H} 2 \mathrm{O}$ & 21659.9 & 33127.5 \\
\hline $\mathrm{CH} 4$ & 2918.9 & 0.0 \\
\hline H2S & 33.2 & 0.0 \\
\hline $\mathrm{NH3}$ & 73.0 & 0.0 \\
\hline $\cos$ & 0.0 & 0.0 \\
\hline $\mathrm{SO} 2$ & 0.0 & 0.0 \\
\hline SO3 & 0.0 & 0.0 \\
\hline NO2 & 0.0 & 0.0 \\
\hline NO & 0.0 & 0.0 \\
\hline PHENOL & 0.0 & 0.0 \\
\hline $\mathrm{C} 6 \mathrm{H} 6$ & 0.0 & 0.0 \\
\hline $\mathrm{C} 2 \mathrm{H} 6$ & 159.1 & 0.0 \\
\hline $\mathrm{C} 2 \mathrm{H} 4$ & 1488.9 & 0.0 \\
\hline $\mathrm{C} 2 \mathrm{H} 2$ & 107.9 & 0.0 \\
\hline $\mathrm{O} 2 \mathrm{SI}$ & 644565.4 & 0.0 \\
\hline CARBON & 0.4 & 0.0 \\
\hline WOOD & 0.0 & 0.0 \\
\hline ASH & 0.0 & 0.0 \\
\hline CHAR & 10815.0 & 0.0 \\
\hline
\end{tabular}




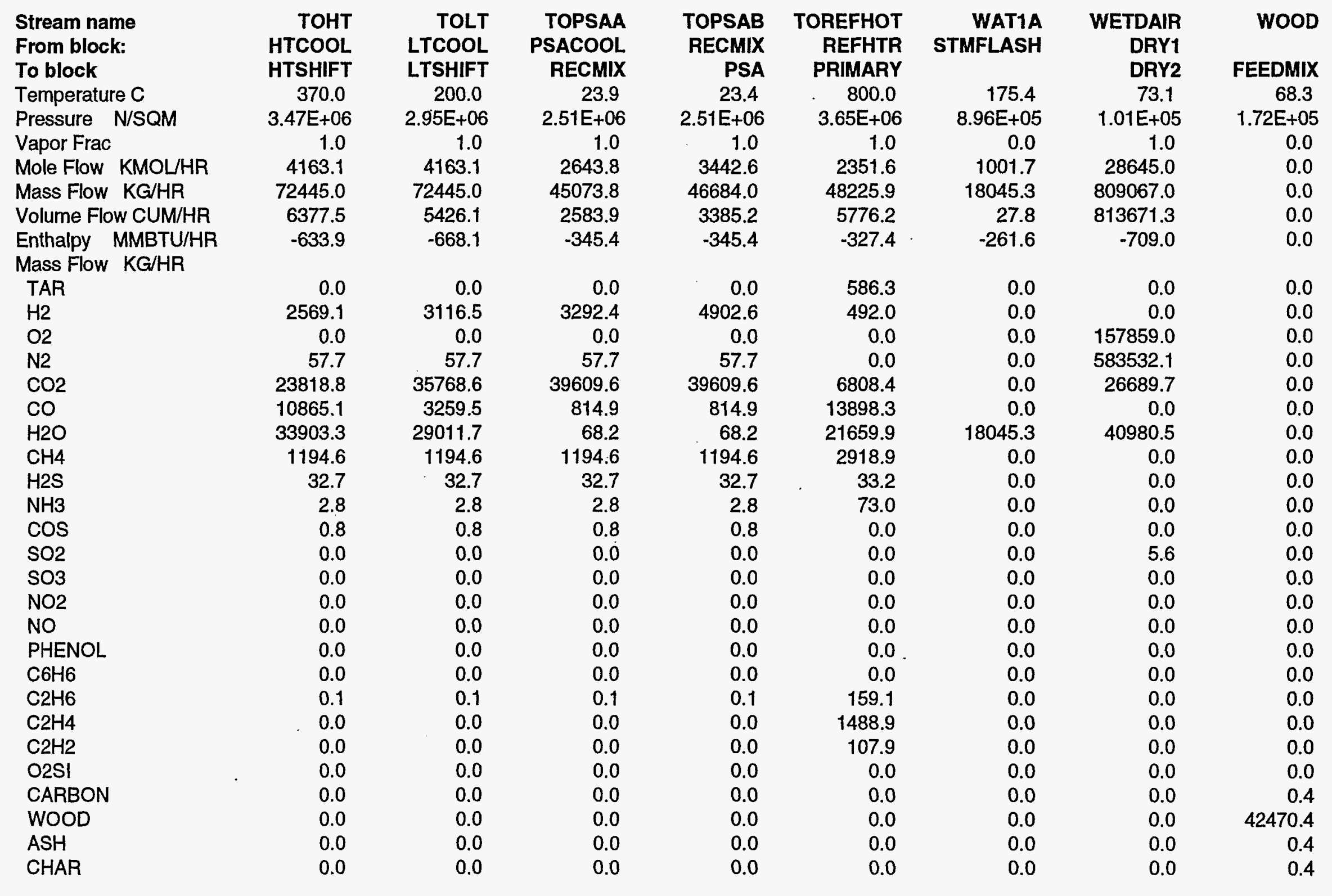




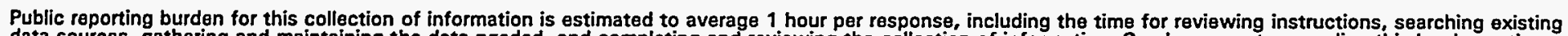

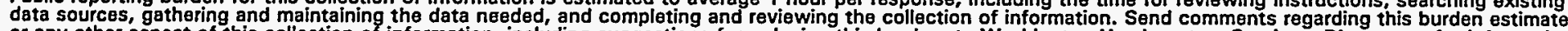

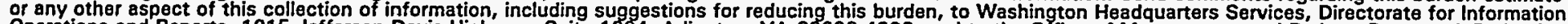

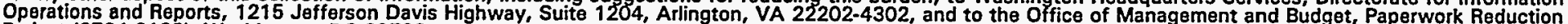
Project (0704-0188), Washington, DC 20503.

\begin{tabular}{l|l|l}
\hline 1. AGENCY USE ONLY (Leave blank) & 2. REPORT DATE & 3. REPORT TYPE AND DATES COVERED \\
& August 1995 & Technical Report \\
\hline
\end{tabular}

4. TITLE AND SUBTITLE

Technical and Economic Assessment of Producing Hydrogen by Reforming Syngas from the Battelle Indirectly Heated Biomass Gasifier.

\section{AUTHOR(S) \\ Margaret K. Mann}

\section{PERFORMING ORGANIZATION NAME(S) AND ADDRESS(ES)}

\section{SPONSORING/MONITORING AGENCY NAME(S) AND ADDRESS(ES)}

National Renewable Energy Laboratory

1617 Cole Boulevard

Golden, CO $80401-3393$

\section{SUPPLEMENTARY NOTES}

\section{2a. DISTRIBUTION/AVAILABILITY STATEMENT}

National Technical Information Service

U.S. Department of Commerce

5285 Port Royal Road

Springfield, VA 22161

13. ABSTRACT (Maximum 200 words)

Author gives new information on the technical and economic factors surrounding hydrogen production at the Battelle Laboratories gasifier.

\section{SUBJECT TERMS}

biomass, gasifiers, hydrogen production

UC-1311

\section{FUNDING NUMBERS}

(C)

(TA) HY51.4041

8. PERFORMING ORGANIZATION REPORT NUMBER

DE95009275

10. SPONSORING/MONITORING AGENCY REPORT NUMBER

NREL/TP-431-8143
15. NUMBER OF PAGES

126

16. PRICE CODE

\begin{tabular}{|l|l|l|l|}
\hline $\begin{array}{l}\text { 17. SECURITY CLASSIFICATION } \\
\text { OF REPORT } \\
\text { Unclassified }\end{array}$ & $\begin{array}{l}\text { 18. SECURITY CLASSIFICATION } \\
\text { OF THIS PAGE }\end{array}$ & $\begin{array}{l}\text { 19. SECURITY CLASSIFICATION } \\
\text { OF ABSTRACT }\end{array}$ & 20. LIMITATION OF ABSTRACT \\
\hline & & & \\
\hline
\end{tabular}

NSN 7540-01-280-5500

Standard Form 298 (Rev. 2-89) Prescribed by ANSI Std. 239-18 